ANDRÉA DE OLIVEIRA SILVA

DINÂMICA COMPETITIVA E TECNOLÓGICA DA INDÚSTRIA DE MÁQUINAS-FERRAMENTA NO BRASIL

São Paulo 
ANDRÉA DE OLIVEIRA SILVA

\section{DINÂMICA COMPETITIVA E TECNOLÓGICA DA INDÚSTRIA DE MÁQUINAS-FERRAMENTA NO BRASIL}

Tese apresentada à Escola Politécnica da Universidade de São Paulo para a obtenção do título de Doutor em Engenharia.

São Paulo

2013 
ANDRÉA DE OLIVEIRA SILVA

\section{DINÂMICA COMPETITIVA E TECNOLÓGICA DA INDÚSTRIA DE MÁQUINAS-FERRAMENTA NO BRASIL}

Tese apresentada à Escola Politécnica da Universidade de São Paulo para a obtenção do título de Doutor em Engenharia.

Área de Concentração: Engenharia de Produção

Orientador: Prof. Dr. Renato de Castro Garcia

São Paulo

2013 
Este exemplar foi revisado e alterado em relação à versão original, sob responsabilidade única do autor e com a anuência de seu orientador.

São Paulo, de janeiro de 2013.

Assinatura do autor

Assinatura do orientador

FICHA CATALOGRÁFICA

Silva, Andréa de Oliveira

Dinâmica competitiva e tecnológica da indústria de máquinas-ferramenta no Brasil / A.O. Silva. -- ed.rev. -- São Paulo, 2013.

$281 \mathrm{p}$.

Tese (Doutorado) - Escola Politécnica da Universidade de São Paulo. Departamento de Engenharia de Produção.

1.Máquinas-ferramenta 2.Desenvolvimento industrial - Brasil 3.Inovações tecnológicas 4.Cooperação universidade-empresa I.Universidade de São Paulo. Escola Politécnica. Departamento de Engenharia de Produção Il.t. 
Silva, A. O. Dinâmica competitiva e tecnológica da indústria de máquinasferramenta no Brasil. Tese apresentada ao Departamento de Engenharia de Produção da Escola Politécnica da Universidade de São Paulo, para obtenção do título de Doutor em Engenharia.

Aprovado em:

Banca examinadora:

Prof. Dr.. Instituição:

Julgamento: Assinatura:

Prof. Dr.. Instituição:

Julgamento: Assinatura:

Prof. Dr.. Instituição:

Julgamento: Assinatura:

Prof. Dr.. Instituição: Julgamento: Assinatura:

Prof. Dr.. Instituição: Julgamento: Assinatura: 
Ofereço à minha família 


\section{AGRADECIMENTOS}

Em primeiro lugar, agradeço aos meus pais e meus irmãos pelo apoio e as palavras de incentivo.

Agradeço aos amigos Wellington, Silvia G., Luciana M., Karine e aos amigos da pósgraduação pelo apoio, o ombro amigo e os puxões de orelha.

Agradeço a CAPES pela bolsa concedida, que possibilitou o desenvolvimento do trabalho.

Agradeço aos professores do departamento de engenharia de produção, pela oportunidade de ampliar os conhecimentos. E aos funcionários da Poli, pela assistência e colaboração.

Agradeço aos professores Davi Nakano e Roberta Castro, pela leitura atenta do documento de qualificação, pelos comentários de grande importância para a pesquisa e pela colaboração também na fase final da tese.

Agradeço aos professores Rogério Gomes e Rodrigo Sabbatini, por sua leitura e a participação nessa fase importante que é a defesa de um doutorado.

Agradeço, principalmente, ao professor Renato Garcia, pela leitura cuidadosa e questionadora e por sua colaboração para tratar um tema pouco distante de sua linha de pesquisa.

Agradeço aos pesquisadores-líderes dos grupos de pesquisa, pelos comentários sobre as características das máquinas e a dinâmica tecnológica do setor e por apresentar elementos importantes para a compreensão sobre as interações universidade-empresa.

Agradeço aos representantes das empresas de máquinas-ferramenta (B. Grob, D. R. Promaq, Ergomat, Ferdimat, Index e Romi) por terem disponibilizado parte de seu tempo para responder às indagações da pesquisa e apresentar a área de produção de suas empresas. Agradeço, especialmente, aos representantes da empresa Romi, pelas aulas que recebi durante as visitas técnicas e por sua colaboração na entrevista.

Por fim, agradeço também aos representantes do Instituto de Pesquisa e Desenvolvimento Tecnológico da Indústria de Máquinas e Equipamentos (IPDMaq), filiado à $A B I M A Q$; e à $A B I M A Q$, pela entrevista concedida, por terem disponibilizado material para consulta e pelo apoio na participação de eventos do setor. 


\section{RESUMO}

Esta tese analisa as características e as condições do desenvolvimento industrial e tecnológico do setor de máquinas-ferramenta no Brasil. $O$ trabalho parte do pressuposto de que há uma relação entre trajetória tecnológica, regime tecnológico e desenvolvimento econômico e considera que o arcabouço sobre Sistema Setorial de Inovação pode trazer importantes contribuições para o desenvolvimento tecnológico entre os setores industriais. A revisão teórica da tese aplicou a discussão sobre trajetória tecnológica, regime tecnológico e Sistema Setorial de Inovação ao caso do setor de máquinas-ferramenta mundial, destacando as características do desenvolvimento das tecnologias do setor na Inglaterra, EUA e Japão. A metodologia de pesquisa abrangeu uma análise sobre o setor de máquinas-ferramenta no Brasil. Esta análise considerou as características do desempenho industrial e tecnológico e as interações realizadas entre empresas de máquinas-ferramenta e grupos de pesquisa sediados no Estado de São Paulo. A partir da análise empírica e setorial, a tese constatou que o regime tecnológico do setor de máquinas-ferramenta do Brasil apresenta características distintas, relativamente ao setor de máquinas-ferramenta dos países analisados na revisão teórica. O Sistema Setorial de Inovação de máquinas-ferramenta no Brasil também apresenta algumas diferenças em relação ao Sistema Setorial de máquinasferramenta da Alemanha, Japão, EUA e Itália. A conclusão é que a escolha das empresas por trajetórias tecnológicas no passado pode repercutir um ambiente tecnológico distinto para um mesmo setor através dos países. Considera-se que as características do ambiente tecnológico de cada setor podem apresentar alguns efeitos positivos para a sua competitividade. Entretanto, no longo prazo, a dinâmica industrial e tecnológica do setor de máquinas-ferramenta nacional pode ser afetada pela escolha entre trajetórias tecnológicas.

Palavras-chave: Máquinas-ferramenta, Desenvolvimento industrial (Brasil); Inovações tecnológicas, Cooperação universidade-empresa, Sistema Setorial de Inovação. 


\begin{abstract}
This thesis analyzes the characteristics and conditions of the industrial and technological development of the machine tools industry in Brazil. The work assumes that there is a relationship between technological trajectory, technological regime and economic development and considers the framework of the Sectoral System of Innovation can make important contributions to technological development among industries. A theoretical review of the thesis applied the discussion on technological trajectory, technological regime and Sectoral System of Innovation in the case of machine tools industry, highlighting the features of the technology development sector in England, USA and Japan. The research methodology includes an analysis of the machine tools industry in Brazil. This analysis considered the performance characteristics of industrial and technological interactions between companies of machine tools and research groups based in São Paulo. From the empirical analysis and sector, the thesis found that the technological regime of the machine tools industry in Brazil has distinct characteristics to the machine tools industry of the countries analyzed in the theoretical review. The machine tools Sectoral System of Innovation in Brazil also have some differences from the System Sector machine tools from Germany, Japan, USA and Italy. The conclusion is that the choice of enterprises by technological trajectories in the past can influence a distinct technological environment for the same sector across countries. It is considered that the characteristics of the technological environment of each sector may have some positive effects on their competitiveness. However, in the long term, the dynamic industrial and technological sector of machine tools can be affected by national choice between technological trajectories.
\end{abstract}

Key words: Machine-tools, industrial development (Brazil), technological innovations, University-industry cooperation, Sectoral System of innovation 


\section{LISTA DE ILUSTRAÇÕES}

Figura 1.1 - Desenvolvimento e trajetórias tecnológicas e Sistema Setorial de inovação ... 22 Gráfico 4.1 - Número de empresas do grupo de máquinas especiais e do setor de máquinas-ferramenta no mundo, 2005-2009. 83

Gráfico 4.2 - Número de trabalhadores empregados no grupo de máquinas especiais e no setor de máquinas-ferramenta no mundo, 2005-2009 84

Gráfico 4.3 - Produção mundial do setor de máquinas e do ramo de máquinas-ferramenta, 2005-2009.

Gráfico 4.4 - Produção de máquinas-ferramenta em países selecionados (1), 2008-2011. 86 Gráfico 4.5 - Produção de máquinas-ferramenta em países selecionados (2) - 2008 a 2011

Gráfico 4.6 - Consumo mundial de máquinas-ferramenta - 2000 a 2010. 88

Gráfico 4.7 - Exportações mundiais de máquinas-ferramenta - 2000 a 2010 90

Fonte: Elaboração própria, com dados de Comtrade. 90

Gráfico 4.8 - Exportações mundiais do setor de máquinas e equipamentos, por SITC 2000 a 2010

Gráfico 4.9 - Participação dos segmentos de máquinas no total de exportações do setor 2000 a 2010

Gráfico 5.1 - Total de unidades locais da indústria de bens de capital do Brasil - 2007 a 2010. 125

Gráfico 5.2 - Unidades locais do setor de máquinas e do segmento de máquinasferramenta do Brasil - 2007 a 2010 126

Gráfico 5.3 - Comércio de máquinas e equipamentos do Brasil - 1996 a 2010 132 


\section{LISTA DE QUADROS}

Quadro 2.1 - Características do Conhecimento-base 44

Quadro 2.2 - Trajetórias tecnológicas setoriais: determinantes, direções e características mensuradas 46

Quadro 3.1 - Tecnologias e características do Sistema de Manufatura Computadorizado . 65 Quadro 3.2 - Trajetórias tecnológicas importantes para a indústria de máquinas-ferramenta mundial. 68

Quadro 3.3 - Características gerais das atividades inovativas para a categoria de fornecedores especializados 69

Quadro 4.1 - Descrição das máquinas-ferramenta de usinagem .... 75

Quadro 4.2 - Categoria de processos e exemplos. 77

Quadro 4.3 - Descrição de alguns processos usinagem.... 78

Quadro 4.4 - Categoria de processos e a importância de parâmetros selecionados 79

Quadro 4.5 - Requisitos dos materiais para aplicação e índices de avaliação de desempenho 80

Quadro 4.6 - Descrição dos segmentos pertencentes ao setor Metalworking machinery ... 89 Quadro 4.7 - Características tradicionais e emergentes do Sistema de inovação no setor de máquinas-ferramenta. 101

Quadro 4.8 - Spectro da inovação na indústria de máquinas-ferramenta da Alemanha, Itália, Japão e EUA

Quadro 4.9 - Principais atores e características do desenvolvimento do setor de máquinasferramenta - países selecionados 115

Quadro 5.1 - Produtos incluídos na classe Fabricação de máquinas-ferramenta . 124

Quadro 6.1 - Fontes informação utilizadas para a identificação, seleção e análise sobre o setor, empresas e tecnologias do ramo de máquinas-ferramenta do Brasil 139

Quadro 6.2 - Empresas de máquinas-ferramenta selecionadas para a pesquisa empírica143 Quadro 6.3 - Variáveis utilizadas na seleção dos grupos de pesquisa 144

Quadro 6.4 - Grupos de pesquisa selecionados. 147 
Quadro 6.5 - Conceitos e construtos utilizados na pesquisa empírica..... 148

Quadro 6.6 - Roteiro de questões e variáveis de controles aplicados nas visitas às empresas de máquinas-ferramenta 149

Quadros 6.7 - Variáveis mensuradas na análise sobre o desenvolvimento industrial das empresas de máquinas-ferramenta selecionadas 149

Quadro 6.8 - Variáveis mensuradas na análise sobre o desenvolvimento econômico das empresas de máquinas-ferramenta selecionadas 150

Quadros 6.9 - Variáveis mensuradas sobre o panorama dos produtos e tecnologias nas empresas de máquinas-ferramenta 150

Quadro 6.10 - Características mensuradas na análise sobre a capacidade inovativa das empresas de máquinas-ferramenta selecionadas 150

Quadro 6.11 - Características mensuradas na análise sobre as interações das empresas com o Sistema Setorial de Inovação

Quadro 6.12 - Roteiro de questões e variáveis de controles aplicados nas visitas aos grupos de pesquisa 151

Quadro 6.13 - Características gerais dos grupos de pesquisa selecionados 152

Quadro 6.14 - Grupos de pesquisa selecionados e interações recente registradas com o setor produtivo 152

Quadro 6.15 - Grupos de pesquisa selecionados e características gerais das interações 152 Quadro 7.1 - Características gerais das empresas de máquinas-ferramenta selecionadas154 Quadro 7.2 - Empresas de máquinas e linhas de produtos 155

Quadro 7.3 - Faixas de mercado e características das tecnologias embarcadas 156

Quadro 7.4 - Fator de competitividade e características das barreiras à entrada, segundo as faixas de mercado. 162

Quadro 7.5 - Grupos de pesquisa analisados 176

Quadro 7.6 - Linhas de pesquisa e áreas de conhecimento predominante dos grupos de pesquisa analisados 177

Quadro 7.7 - Características gerais dos grupos de pesquisa analisados. 178

Quadro 7.8 - Número de integrantes dos grupos de pesquisa analisados 180

Quadro 7.9 - Grupos de pesquisa e interações desenvolvidas recentemente 181

Quadro 7.10 - Quantidades de interações por natureza 185 
Quadro 8.1 - Sistema Setorial de Inovação de máquinas-ferramenta: o caso do setor de máquinas-ferramenta do Brasil ............................................................................. 211 


\section{LISTA DE TABELAS}

Tabela 4.1 - Exportações de máquinas-ferramenta que trabalham metal, por eliminação de metal ou outro material (SIT 731), principais países, 2009 e 2010

Tabela 4.2 - Importações de máquinas-ferramenta que trabalham metal, por eliminação de metal ou outro material (SIT 731), por países selecionados, 2009 e 2010. 93

Tabela 4.3 - Exportações de máquinas-ferramenta que trabalham metal, sem eliminação de material (SIT 733), por países selecionados, 2009 e 2010.

Tabela 4.4 - Importações de máquinas-ferramenta que trabalham metal, sem eliminação de material (SIT 733), por países selecionados, 2009 e 2010.

Tabela 4.5 - Índice de concentração das exportações de Máquinas-ferramenta. 96

Tabela 4.6 - Índice de concentração das importações de Máquinas-ferramenta. 96

Tabela 4.7 - Índice de mudança estrutural das exportações e importações de Máquinasferramenta

Tabela 5.1 - Participação das unidades locais dos setores de máquinas no total da indústria de bens de capital do Brasil - 2007 a 2010.

Tabela 5.2 - Crescimento do número de unidades locais com produção de máquinasferramenta do Brasil - 2007 a 2010

Tabela 5.3 - Total de Estabelecimentos com produção de máquinas-ferramenta, por Estados região sul e sudeste - períodos selecionados. 128

Tabela 5.4 - Número de estabelecimentos do ramo de máquinas-ferramenta localizados na microrregião de São Paulo.

Tabela 5.5 - Número de empresas, por faixa de pessoal ocupado, no segmento de máquinas-ferramenta do Brasil- 2007 a 2010.

Tabela 5.6 - Valor da produção do segmento de máquinas-ferramenta do Brasil - 2007 a 2010

Tabela 5.7 - Utilização de capacidade instalada da indústria de transformação (\%) no Brasil -2007 a 2010 131

Tabela 5.8 - Importações de máquinas-ferramenta do Brasil, por SITC - 2008 a 2010 ... 132 


\section{LISTA DE ABREVIATURAS E SIGLAS}

$\begin{array}{cl}\text { ABIMAQ } & \text { Associação Brasileira da Indústria de Máquinas e Equipamentos } \\ \text { CNAE } & \text { Classificação Nacional de Atividade Econômica } \\ \text { CNI } & \text { Confederação Nacional das Indústrias } \\ \text { CNPQ } & \text { Conselho Nacional de Desenvolvimento Científico e Tecnológico } \\ \text { FIESP } & \text { Federação das Indústrias do Estado de São Paulo } \\ \text { FMS } & \text { Flexible Manufacturing Systems } \\ \text { IBGE } & \text { Instituto Brasileiro de Geografia e Estatística } \\ \text { IPDMaq } & \text { Instituto de Pesquisa e Desenvolvimento Tecnológico da Indústria } \\ & \text { de Máquinas e Equipamentos } \\ \text { ISIC } & \text { International Standard of Industrial Classification } \\ \text { MIT } & \text { Massachusetts Institute of Technology } \\ \text { NCM } & \text { Nomenclatura Comum do Mercosul } \\ \text { SITC } & \text { Standard International Trade Classification } \\ \text { UNCTAD } & \text { United Nations Conference on Trade and Development } \\ \text { UNIDO } & \text { United Nations Industrial Development Organization }\end{array}$




\section{SUMÁRIO}

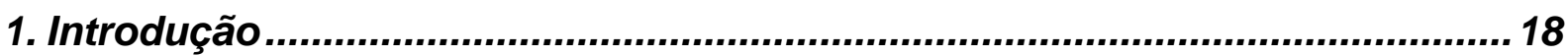

Capítulo 2 - Desenvolvimento tecnológico e a indústria de bens de capital .....27

2.1 Tecnologias, trajetória tecnológica e mudança técnica ........................................ 27

2.2 Regime tecnológico e Sistema Setorial de Inovação ............................................... 37

Capítulo 3 - Desenvolvimento e mudança técnica na indústria de bens de

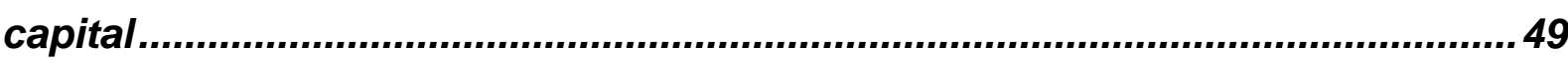

3.1 A indústria de bens de capital e o desenvolvimento econômico ........................... 49

3.2 Padrões e rupturas no desenvolvimento tecnológico da indústria de bens de

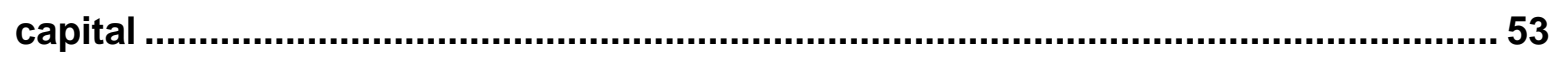

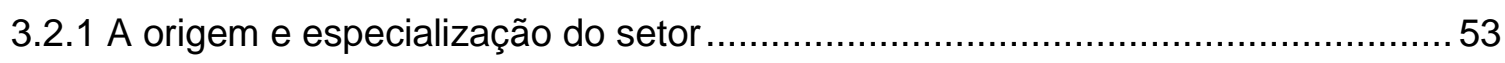

3.2.2 Automação e desenvolvimento tecnológico ........................................................ 62

3.3 Padrão setorial e regime tecnológico na indústria de bens de capital ................. 69

Capítulo 4 - 0 setor de máquinas-ferramenta em países selecionados..............73

4.1 Produtos, processos e tecnologias do setor de máquinas-ferramenta. ...............73

4.2 Produção e comércio mundial do setor de máquinas-ferramenta ........................ 83

4.4 Considerações sobre o setor de máquinas-ferramenta em países selecionados99

Capítulo 5 - 0 setor de máquinas-ferramenta no Brasil ..................................117

5.1 Panorama sobre o setor de máquinas-ferramenta no Brasil ............................... 117

5.2 A dinâmica industrial e competitiva do segmento de máquinas-ferramenta .... 123

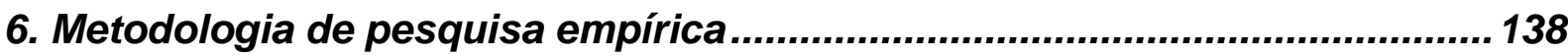

6.1 Fases da pesquisa e fontes de informações utilizadas....................................... 138

6.2 Objeto de estudo da análise empírica da tese ................................................ 141

6.2.1 A Identificação e seleção das empresas de máquinas-ferramenta .......................141

6.2.2 A identificação e seleção dos grupos de pesquisa .......................................... 144

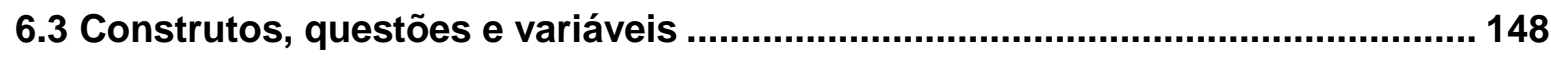

Capítulo 7 - Estudo empírico sobre o setor de máquinas-ferramenta.............. 153

7.1 Empresas de máquinas-ferramenta e as características das interações 
mensuradas com o setor 153

7.1.1 Características gerais das empresas de máquinas-ferramenta ......................... 153

7.1.2 Fatores de competitividade das empresas de máquinas-ferramenta .................. 159

7.1.3 Análise qualitativa sobre o desempenho industrial e comercial das empresas de máquinas-ferramenta selecionadas ............................................................... 163

7.1.4 Capacidade inovativa interna das empresas analisadas ............................... 166

Características da área de engenharia das empresas...................................... 166

Processo de produção das máquinas ................................................................. 167

7.1.5 Características das interações e resultados apontados por empresas de

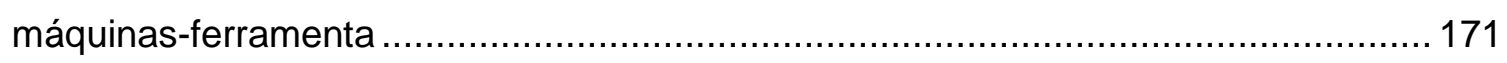

7.2 Grupos de pesquisa e as características das interações mensuradas com setor

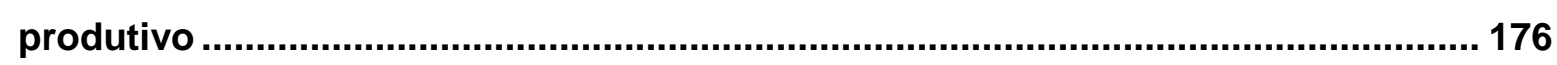

7.2.1 Origem e desenvolvimento dos grupos de pesquisa analisados........................ 176

7.2.2 Características das interações e principais resultados apontados por grupos de

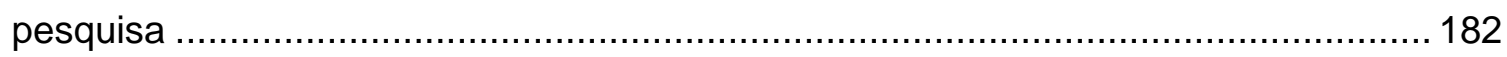

7.3 As dificuldades nas interações entre as empresas de máquinas e os grupos de

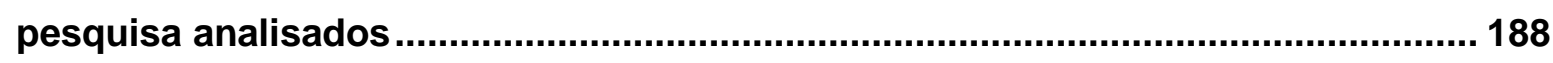

Capítulo 8 - Considerações sobre o setor de máquinas-ferramenta no Brasil 192

8.1 Desenvolvimento industrial e trajetórias tecnológicas do setor de máquinas-

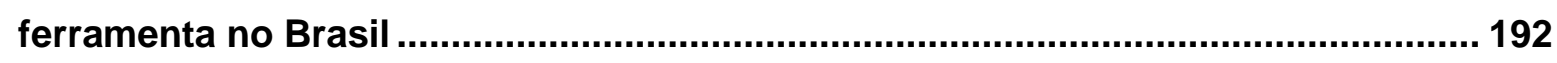

8.2 O regime tecnológico do setor de máquinas-ferramenta do Brasil..................... 201

8.3 Elementos do Sistema Setorial de Inovação de máquinas-ferramenta no Brasil205

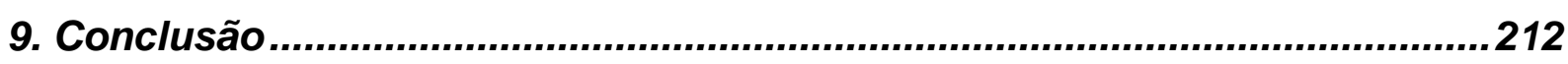

Referências Bibliográficas .........................................................................219

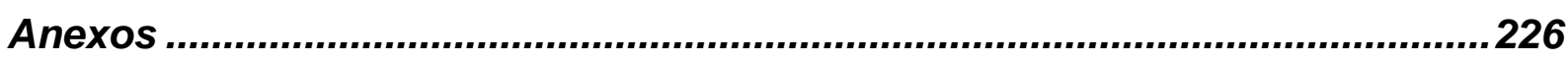




\section{Introdução}

Esse trabalho apresenta uma análise sobre o desenvolvimento mundial de tecnologias no setor de máquinas-ferramentas. A tese apresenta a preocupação em discutir os fatores que influenciaram e têm influenciado a mudança tecnológica no setor de máquinas em diferentes países, enfatizando algumas características e condições impostas para o desenvolvimento tecnológico do setor no Brasil.

A revisão teórica da tese está apoiada na discussão sobre os conceitos de trajetórias tecnológicas, mudança técnica e regime tecnológico e considera que há uma relação importante entre esses conceitos e o arcabouço de Sistema Setorial de Inovação.

O objeto central da análise teórica e empírica da tese é a empresa e sua interação com o ambiente no qual ela está inserida.

Considera-se que as empresas desenvolvem diferentes rotinas ou conjuntos de conhecimentos sobre alternativas tecnológicas. Ao longo do tempo, essas empresas podem incorporar novos conhecimentos às rotinas, criando novas alternativas tecnológicas. As escolhas por um conjunto de tecnologias, dentro de um padrão de solução de problemas (ou paradigma tecnológico), por sua vez, podem ser definidas como trajetórias tecnológicas.

As empresas e setores industriais apresentam heterogeneidade de condições para a incorporação e aprendizado de trajetórias tecnológicas.

De um lado, o ambiente ou regime tecnológico no qual as empresas estão inseridas reúne condições de oportunidade e apropriabilidade; base de conhecimentos e níveis de cumulatividade dos conhecimentos que são específicos a cada setor. De outro lado, o regime tecnológico abrange diferentes estratégias relacionadas ao processo de criação, incorporação e difusão de tecnologias.

O ambiente no qual as empresas estão inseridas pode influenciar a identificação de trajetórias tecnológicas e a mudança técnica entre os setores industriais. Entretanto, considera-se que a identificação e o aprendizado de trajetórias tecnológicas dentro de um paradigma tecnológico não são influenciados apenas por condições do ambiente tecnológico estrito.

O ambiente institucional, aqui compreendido como infraestrutura científica, o Estado, os fornecedores e os usuários apresentam papel relevante para o 
aprendizado de tecnologias e a mudança técnica. O setor de máquinas-ferramentas é um caso representativo da influência que o ambiente tecnológico e institucional exerce sobre o desenvolvimento tecnológico ao nível setorial.

No século XIX, o desenvolvimento do setor de máquinas no mundo esteve apoiado em conjunto de conhecimentos em comum e em conjunto de problemas técnicos no processo de produção de máquinas para diferentes setores industriais. O conjunto de conhecimentos e de problemas técnicos em comum visualizados no setor de máquinas é apresentado na literatura como convergência tecnológica.

Ao longo do século XIX e XX, o desenvolvimento de tecnologias no setor de máquinas contou com importante participação de diferentes atores do ambiente em que as empresas estão inseridas.

Em países como a Inglaterra e os EUA, por exemplo, as interações realizadas entre as empresas com produção de máquinas e os usuários de tais máquinas exerceram influência sobre a direção e a velocidade da mudança técnica do setor. À medida que os conhecimentos eram incorporados e ampliados no ambiente interno das empresas de máquinas, visando o atendimento de requisitos dos usuários, verifica-se a desintegração vertical e a formação de novos ramos industriais de máquinas para diferentes usos.

A partir do século $X X$, o desenvolvimento técnico das empresas de máquinas daqueles países também passou a contar com a infraestrutura científica, a participação do Estado e com as interações estabelecidas com fornecedores de insumos e de componentes eletrônicos incorporados às máquinas.

Esse conjunto de fatores orientou as estratégias de desenvolvimento tecnológico entre as empresas e contribuiu de maneira distinta para o desenvolvimento industrial do setor de máquinas de cada país.

Vale notar que a percepção das empresas e segmentos industriais em relação às trajetórias tecnológicas vigentes e potenciais influenciou a direção e velocidade da mudança técnica das máquinas.

A partir de meados do século $X X$, o surgimento de novas trajetórias tecnológicas com as tecnologias de automação e as mudanças nas propriedades físicas dos materiais utilizados na produção das máquinas repercutiram em alterações na base de conhecimentos do setor de máquinas.

Em países como a Alemanha e Japão, a percepção das empresas de máquinas-ferramentas em relação ao potencial comercial de tais tecnologias foi um 
fator significativo para o desenvolvimento técnico do setor de máquinas-ferramentas. Vale notar que naqueles países, a infraestrutura científica, tecnológica e o Estado promoveram e reforçaram as condições para a difusão e aprendizado das tecnologias e conhecimentos identificados por empresas individuais.

O setor de máquinas-ferramentas dos EUA e Inglaterra, por sua vez, não apresentaram as mesmas condições para o desenvolvimento de tecnologias verificadas na Alemanha e no Japão. Em países de industrialização recente como o Brasil, o setor de máquinas-ferramenta apresenta uma heterogeneidade de condições produtivas, do ambiente institucional e tecnológico que influenciam a direção da mudança técnica.

O conceito sobre trajetórias tecnológicas e regime tecnológico e o arcabouço sobre Sistema Setorial de Inovação do setor de máquinas-ferramentas ajudam a compreender as características e o dinamismo do desenvolvimento de tecnologias entre os segmentos de máquinas diante de novas trajetórias tecnológicas.

Considera-se que cada ramo industrial de máquinas apresenta diferentes condições de oportunidade e apropriabilidade e características da base de conhecimentos. Essa característica, por sua vez, pode ser atribuída às estratégias utilizadas para a criação, difusão e aprendizado de tecnologias.

O ambiente institucional pode reforçar ou alterar as condições do ambiente tecnológico no qual as empresas estão inseridas. De maneira geral, as características da demanda em cada país influenciam as escolhas iniciais entre as trajetórias tecnológicas vigentes.

A infraestrutura científica e tecnológica de cada país pode apoiar a identificação de novas rotas tecnológicas ou promover rupturas em relação à trajetória tecnológica vigente. Isso porque a integração entre pesquisa científica e empírica amplia a base de conhecimentos internos às empresas e o aprendizado de tecnologias entre as empresas. A participação do Estado e de empresas individuais e os vínculos estabelecidos ao longo da cadeia também contribuem para a difusão de tais tecnologias e a internalização dos conhecimentos no sistema econômico.

A discussão sobre a relação entre regime tecnológico e Sistema Setorial de Inovação de máquinas-ferramentas está apoiada em análise empírica do setor de máquinas dos EUA, Alemanha, Japão e Itália. Entretanto, a tese não apresenta propósito de analisar profundamente as características e influência de cada um dos atores do Sistema Setorial de Inovação de máquinas-ferramentas naqueles países. 
Após a discussão empírica sobre países selecionados, a tese aplica a discussão sobre Sistema Setorial de inovação ao caso do setor de máquinasferramenta do Brasil, considerando a relação estabelecida entre as empresas desse setor e um grupo de instituições de pesquisa sediadas no Estado de São Paulo.

O objetivo da tese é analisar as características e as condições do desenvolvimento industrial e tecnológico das empresas do setor de máquinasferramenta do Brasil no período recente.

O trabalho considera as características, a dinâmica e os resultados das interações entre empresas e grupos de pesquisa e eventuais dificuldades enfrentadas por esses atores.

Para realizar a discussão empírica, a tese parte do pressuposto, presente na literatura, de que há uma interdependência entre o paradigma tecnológico, a mudança técnica e as trajetórias tecnológicas. E essa interdependência constitui fator importante para compreender características do desenvolvimento industrial e tecnológico das empresas de máquinas-ferramenta em países de industrialização recente.

Considera-se que as particularidades no regime tecnológico e da trajetória tecnológica do setor de máquinas-ferramenta do Brasil são importantes para explicar o seu desempenho industrial e tecnológico recente. Além disso, considera-se que a interação entre os componentes (e atores) de um Sistema Setorial para um dado regime tecnológico pode influenciar ou viabilizar a mudança técnica de setores e empresas. A figura 1 apresentada a seguir ilustra a ideia central tratada na discussão teórica da tese. 


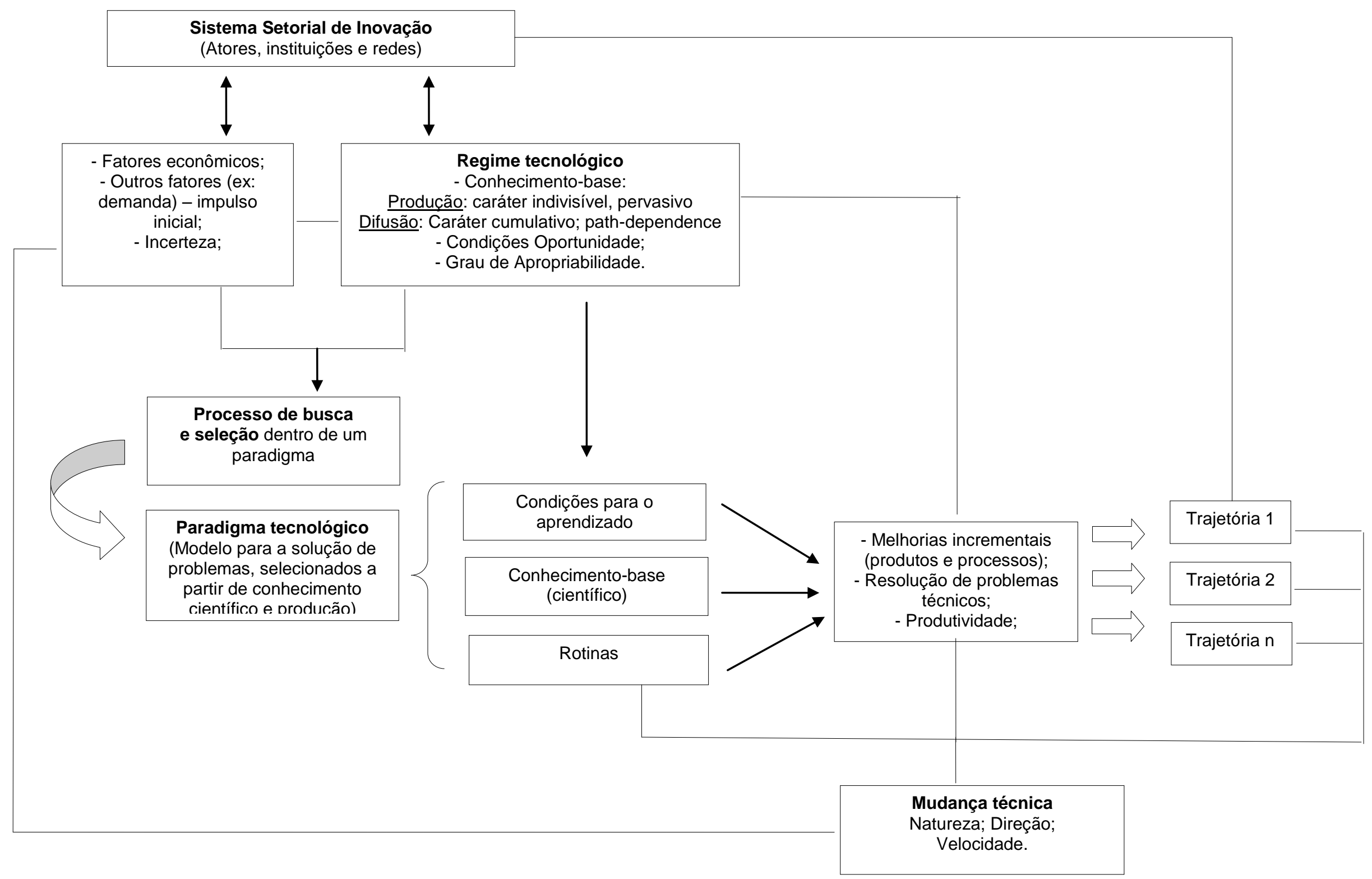


A discussão do caso brasileiro está organizada em três partes. Em primeiro lugar, são discutidos as características e o desempenho industrial do setor de máquina-ferramenta do Brasil no período recente.

Em segundo lugar, são delimitadas as principais características do desenvolvimento industrial e tecnológico para uma amostra de empresas de máquinas-ferramenta com unidades localizadas no Estado de São Paulo. Além disso, é identificada e discutida a dinâmica das interações e os resultados dos vínculos estabelecidos do ponto de vista de alguns grupos de pesquisa selecionados e que apresentam atuação no ramo de máquinas e equipamentos.

Em terceiro lugar, são apresentadas as principais características do desenvolvimento industrial e do regime tecnológico para o grupo de empresas à luz do desenvolvimento do setor de máquinas.

A partir dos resultados obtidos na análise teórica e empírica da tese, é possível constatar que o Sistema Setorial de máquinas-ferramentas do Brasil apresenta elementos próximos ao Sistema Setorial de máquinas tradicional. Além disso, a pesquisa empírica e teórica possibilitou a identificação de um ambiente tecnológico com baixa oportunidade, alta apropriabilidade, e especialização de conhecimentos na base técnica mecânica.

As informações obtidas por meio de visitas técnicas e entrevistas realizadas com representantes de empresas de máquinas e grupos de pesquisa do Estado de São Paulo permitiram a identificação de um perfil de interações visando o desenvolvimento de tecnologias. Essa característica pode ser atribuída, em grande medida, ao próprio padrão de desenvolvimento, incorporação e difusão de tecnologias do setor de máquinas-ferramenta do Brasil.

A tese está organizada nove capítulos que abrange a introdução; seis capítulos com a discussão teórica e empírica da tese; o capítulo com os procedimentos metodológicos e o capítulo de conclusão. Ao final do arquivo, a tese apresenta as referências bibliográficas utilizadas e consultadas e os anexos.

O capítulo um corresponde à introdução da tese, que foi organizada em três seções. Além desta primeira seção com a organização da tese, o primeiro 
capítulo apresenta o tema central da tese (seção 2) e as justificativas e objetivos da pesquisa (seção 3).

O capítulo dois apresenta e discute os principais fatores abordados na discussão conceitual sobre mudança técnica e processo de inovação.

Em primeiro lugar, o capítulo define tecnologia e mudança técnica e analisa a natureza, direção e velocidade da mudança técnica no longo prazo. Além disso, o capítulo estabelece uma relação entre mudança técnica, trajetória e paradigma tecnológico.

Em segundo lugar, o capítulo discute as características gerais dos regimes tecnológicos (condições de oportunidade, apropriabilidade, cumulatividade e conhecimento-base).

Em terceiro lugar, o capítulo apresenta a noção sobre Sistema Setorial de Inovação e Padrão Setorial de Criação e Difusão de conhecimentos.

O capítulo três analisa as características do desenvolvimento industrial e tecnológico da indústria de bens de capital no mundo, enfatizando os elementos e os atores envolvidos na mudança técnica no setor.

Primeiramente, são apresentados os determinantes da formação da indústria e o seu papel para o desenvolvimento econômico nas economias capitalistas no século XIX e XX.

Posteriormente, são discutidos os padrões e rupturas no desenvolvimento de tecnologias da indústria. Nesse sentido, o capítulo direciona a discussão para três elementos que contribuem para diferenças na direção e velocidade da mudança técnica entre os setores de máquinas: a origem e especialização do setor; a alteração em seu padrão de desenvolvimento a partir da inserção da microeletrônica; e as características de seu regime tecnológico.

O capítulo quatro apresenta o panorama do setor de máquinasferramenta. Este capítulo está dividido em três seções.

A primeira seção apresenta os produtos, processos e tecnologias do setor de máquinas.

A segunda seção apresenta e discute a estrutura industrial, a produção e o comércio mundial do setor de máquinas-ferramenta. 
A terceira seção do capítulo quatro analisa a experiência de quatro países selecionados (Alemanha, Itália, Japão e EUA), que têm participação importante na produção do setor de máquinas-ferramenta.

Essa seção destaca as principais características e fatores envolvidos no desenvolvimento do ramo de máquinas-ferramenta daqueles países, considerando a idéia de regime tecnológico e Sistema Setorial de inovação.

O propósito deste capítulo é mostrar que as diferenças nos resultados da produção e comércio do setor de máquinas-ferramenta mundial podem ser explicadas por diferenças na configuração do Sistema Setorial de Inovação em cada um daqueles países.

O capítulo cinco analisa o setor de máquinas-ferramenta do Brasil considerando a discussão teórica da primeira parte da tese. O capitulo está organizado em três seções

A primeira seção apresenta um breve panorama sobre o setor nas últimas décadas do século passado, enfatizando o desenvolvimento de tecnologias.

A segunda seção discute dados recentes sobre a estrutura industrial considerando número e localização das unidades produtivas, perfil das empresas, o emprego do setor, a produção nacional e a participação do setor de máquinas-ferramenta no comércio internacional. Além disso, a seção apresenta as características da dinâmica competitiva e tecnológica do setor de máquinas-ferramenta do Brasil no período recente.

O capítulo seis da tese apresenta a metodologia da pesquisa empírica, que foi organizada em seis seções.

A primeira, segunda e terceira seções deste capítulo apresentam o objeto de estudo; os pressupostos e hipótese da tese; e os construtos e as questões de pesquisa que foram elaborados a partir da discussão teórica e empírica.

A quarta seção apresenta as fontes de informação utilizadas na identificação das empresas e grupos de pesquisa e na análise empírica da tese.

A quinta seção apresenta os critérios utilizados para identificar empresas de máquinas-ferramenta e grupos de pesquisa com atuação no ramo de 
máquinas e equipamentos. A sexta e última seção discute brevemente as opções e limitações da análise empírica da tese.

O capítulo sete abrange a análise empírica sobre o desenvolvimento de empresas do setor de máquinas-ferramenta (MFs) do Brasil, considerando as condições impostas pelo regime tecnológico do setor e como o Sistema Setorial de máquinas-ferramenta nacional tem lidado com as transformações nos últimos anos. O capítulo foi organizado em duas seções.

A primeira seção do capítulo apresenta e analisa os dados obtidos por meio das entrevistas e visitas técnicas realizadas junto às empresas de máquinas-ferramenta localizadas no Estado de São Paulo.

A segunda seção deste capítulo discute as informações obtidas através da entrevista realizada junto aos líderes dos grupos de pesquisa de instituições de ensino superior do Estado de São Paulo, que atuam na área de conhecimento de engenharia mecânica e de produção e no setor de aplicação máquinas e equipamentos.

O capítulo oito aplica a discussão sobre regime tecnológico e Sistema Setorial de Inovação ao caso do setor de máquinas-ferramenta nacional, considerando as informações apresentadas na revisão teórica e empírica da tese. $O$ capítulo nove apresenta a conclusão da tese.

O anexo da tese apresenta três partes. O anexo A apresenta oito quadros com classificações de atividade econômica e comércio internacional e o valor adicionado para a indústria de bens de capital.

O anexo B apresenta dois roteiros de questões que foram aplicadas, respectivamente, com representantes das empresas de máquina-ferramenta e com representantes dos grupos de pesquisa.

O anexo C apresenta informações secundárias sobre as empresas de máquinas-ferramenta e os grupos de pesquisa analisados. Os dados divulgados no anexo C são uma compilação de informações disponíveis no sítio eletrônico das empresas e dos grupos de pesquisa, em fontes secundárias como jornais, e no diretório Grupo de Pesquisa CNPq. As informações obtidas através das entrevistas foram analisadas de maneira agregada no capítulo 7 e não constam no anexo para preservar o sigilo. 


\section{Capítulo 2 - Desenvolvimento tecnológico e a indústria de bens de capital}

O segundo capítulo da tese apresenta e discute os principais fatores abordados na literatura sobre mudança técnica e o processo de inovação.

Em primeiro lugar, o capitulo define tecnologia e mudança técnica e analisa as características da natureza, direção e velocidade da mudança técnica no longo prazo. Além disso, o capítulo estabelece uma relação entre mudança técnica, trajetória e paradigma tecnológico. Em segundo lugar, o capítulo discute os componentes do regime tecnológico: condições de oportunidade, apropriabilidade, cumulatividade e conhecimento-base e apresenta o arcabouço sobre Sistema Setorial de Inovação.

O objetivo deste capítulo é mostrar que há uma relação intrínseca entre trajetória tecnológica, regime tecnológico e Sistema Setorial de Inovação. Além disso, essa relação é importante para compreender as características do desenvolvimento tecnológico de um mesmo setor em diferentes países.

\subsection{Tecnologias, trajetória tecnológica e mudança técnica}

A mudança técnica tem apresentado importante contribuição para o desenvolvimento econômico e industrial entre os países. Em grande medida, a análise das características da mudança técnica remete à idéia de que há uma relação intrínseca entre ciência, tecnologia e desenvolvimento econômico.

De um lado, essa relação assume contornos distintos por conta das características da mudança técnica entre os setores e empresas. De outro lado, há elementos do ambiente que moldam e influenciam o modo como a mudança técnica é realizada entre os países e os impactos sobre o cenário econômico no longo prazo.

Apesar de apresentar algumas modificações ao longo do tempo, a literatura que trata da relação entre mudança técnica e desenvolvimento é relativamente antiga e apresenta uma variedade de contribuições teóricas e empíricas. 
A discussão parte do pressuposto de que as tecnologias são os insumos envolvidos na fabricação de um produto e a mudança técnica refere-se às mudanças nessas atividades de transformação (Fransman, 1986). A tecnologia também pode ser definida como conjunto ordenado de conhecimentos que estão organizados, integrados e articulados no processo de produção (Sabato, 1979). Esse conjunto de conhecimentos, por sua vez, pode se apresentar de duas maneiras: incorporada e desincorporada.

A tecnologia incorporada se comporta como uma matéria-prima. É aquela contida nos bens físicos, como bens de capital; insumos para a produção, como matérias-primas básicas e intermediárias e componentes; e para reposição. A tecnologia não incorporada se comporta como bem de capital. Trata-se dos conhecimentos (ou know how) contidos em documentos (patentes, desenhos, manuais, estudos e informes técnicos), e em pessoal técnico e de engenharia, que possibilitam que o processo possa ser replicado quantas vezes for necessário (Dosi, 2006). As tecnologias também abrangem um conjunto de conhecimentos práticos e teóricos, que influenciam as atividades inovativas:

Os "conhecimentos práticos estariam ligados a problema produtivos concretos e às relações entre produtores e usuários dos bens e serviços. Os problemas teóricos, por sua vez, envolveriam know how, métodos, procedimentos, experiências de sucesso e fracasso" (Dosi, 1982, p. 152).

As tecnologias podem surgir de três maneiras: como soluções de problemas de engenharia; por meio de invenções não deliberadas; ou através de invenções que solucionam problemas técnicos usando novos princípios (Bueno, 2009, p. 537 apud Arthur, 2009). Nesse sentido, os conhecimentos embutidos em tais tecnologias assumem características específicas ao longo do tempo, como resultado de esforços voltados às soluções tecnológicas ou de melhorias do estado-da-arte (Dosi, 2006).

Considerando essas definições sobre tecnologia, a mudança técnica pode ser entendida como processo de transformação de tecnologias incorporadas e desincorporadas, o que abrange os conhecimentos práticos e teóricos, visando à produção de um volume maior de produtos e as melhorias do processo de produção. 
A literatura aponta uma série de fatores que podem conferir especificidades à natureza e à direção da mudança técnica no longo prazo.

Em primeiro lugar, a mudança técnica apresenta natureza diversa entre os setores e países e pode ser classificada em duas categorias: mudança técnica radical e incremental. A mudança técnica radical representa uma ruptura em relação aos conhecimentos ou tecnologias que originou tal mudança. A mudança técnica incremental, por sua vez, corresponde a melhorias realizadas sob a mesma base de conhecimentos que a originaram.

Em segundo lugar, a mudança técnica também pode ser realizada em direções distintas em um mesmo setor industrial em diferentes países ou em diferentes economias. Os principais fatores que podem explicar as direções da mudança técnica são as características do estado-da-arte da tecnologia em uso, os níveis tecnológicos alcançados nos setores ou economias (Dosi, 2006) e o processo de criação e difusão dos conhecimentos tecnológicos no interior dos setores industriais e países.

O processo de criação de conhecimentos apresenta caráter cumulativo e está pautado em experiências históricas e habilidades específicas do passado, que são desenvolvidas de diferentes maneiras (incorporando ou excluindo informações) ao longo dos anos. O processo de incorporação e difusão de conhecimentos, por sua vez, está pautado, principalmente, nas habilidades para reconhecer o potencial da tecnologia, apropriar-se dos conhecimentos, alterar as suas características e incorporá-los à base de conhecimentos internos.

As habilidades e conhecimentos acumulados por empresas e setores industriais são utilizados como base para incorporar (criar) novos conhecimentos e para identificar o potencial desses conhecimentos, o que tende a reforçar a direção da mudança técnica ao longo dos anos.

O ambiente de seleção em que ocorre o processo de criação e difusão de conhecimentos é um fator importante para a discussão sobre a direção da mudança técnica.

Na literatura econômica tradicional, a mudança técnica é explicada pelo pressuposto de que há um amplo conjunto de opções tecnológicas disponíveis e que os agentes econômicos apresentam perfeito conhecimento sobre essas tecnologias, incorporando as técnicas que poderão otimizar seu desempenho 
produtivo e econômico. Na literatura evolucionária, por sua vez, o ambiente de seleção apresenta diferentes opções tecnológicas e os agentes (seja empresas, setores ou países) apresentam informação incompleta sobre as tecnologias disponíveis. Por esse motivo, aqueles agentes tomarão as suas decisões pautadas pelo pressuposto da racionalidade limitada, considerando as melhores oportunidades de produto, processo e mercado.

No cenário formado por diferentes opções tecnológicas e no qual as informações são limitadas, as empresas e os setores apresentam padrões de comportamento regulares (ou rotinas) para as atividades produtivas e não produtivas (Nelson, 1988).

As rotinas podem ser definidas como conjuntos de conhecimentos sobre alternativas tecnológicas (efetiva ou potencial), que funcionam como um padrão de soluções ou paradigma tecnológico. As rotinas determinarão o que a empresa faz, considerando a existência de variáveis externas e internas às empresas (Nelson \& Winter, 1982, p. 35).

Cada paradigma constitui um modelo para a busca e solução de problemas técnicos e econômicos, que são selecionados a partir de princípios derivados de conhecimentos científicos e da área de produção (Dosi, 1982). O processo de busca dentro de um paradigma envolve procedimentos e competências que são específicos a cada tecnologia ou a cada setor.

No ramo da química orgânica, por exemplo, "a busca se dá em torno dos componentes existentes, auxiliada pelo conhecimento científico da relação entre estruturas físicas e propriedades químicas, pela experiência prévia e pelo acaso" (Dosi, 1988, p. 8).

$\mathrm{Na}$ engenharia mecânica, o processo de busca é orientado por trade-offs em relação às características do uso da máquina (como velocidade, flexibilidade e precisão de corte). Além disso, a busca envolve experiências tácitas tanto no projeto e uso de equipamentos mecânicos como na interface entre controles eletrônicos e movimentos mecânicos (Dosi, 1988, p. 8).

Ao longo do tempo, novos conhecimentos podem ser incorporados a esse modelo, sem que isso represente ruptura do paradigma existente. As escolhas por tecnologias dentro desse padrão de solução de problemas (paradigmas) podem ser definidas como trajetórias tecnológicas. 
Dosi (2006) considera que as escolhas (ou seleção) de tecnologias são realizadas em vários níveis que abrangem desde a pesquisa até os esforços destinados à produção (seqüência ciência-tecnologia-produção).

O processo de busca e seleção da trajetória tecnológica dentro de um paradigma tecnológico pode ser influenciado por fatores ex ante como os interesses econômicos das organizações envolvidas em P\&D e as histórias tecnológicas dessas organizações (Dosi, 2006, p. 45). Além disso, as características da demanda e fatores econômicos podem influenciar a escolha das trajetórias tecnológicas dentro de um paradigma tecnológico existente ou potencial (Dosi, 1988, p. 20).

A demanda' pode atuar com um 'sistema de recompensas e penalidades', influenciando a escolha entre um conjunto de produtos já determinados por padrões tecnológicos (Dosi, 2006). Fatores econômicos como os níveis e mudanças nos preços relativos das tecnologias (insumos, máquinas); a capacidade de redução de custos da nova tecnologia; e seu potencial para economizar mão-de-obra e acelerar o processo de acumulação de capital também interfere na escolha entre técnicas.

Após a fase de seleção, a trajetória tecnológica apresenta um impulso próprio entre os setores industriais e países, mas as condições econômicas continuarão a influenciar a direção da mudança técnica.

A integração entre as atividades de investigação científica e empírica (esforços sustentados na forma de P\&D) exerce papel importante na viabilidade de uma trajetória tecnológica.

No século XIX, a integração entre essas atividades em países como EUA e Inglaterra, era direcionada, principalmente, para a resolução de dificuldades tecnológicas não solucionadas, em virtude das limitações nas competências desenvolvidas e adquiridas ao longo do tempo.

De um lado, os mecanismos de pesquisa científica ampliaram o acervo de possibilidades tecnológicas e resultaram em processo planejado da tecnologia e do projeto de produção (Braverman, 1974). Além disso, uma parte considerável da atividade científica era internalizada, através de atividades de busca e acumulação tecnológica interna às firmas (Dosi, 1988, p. 17).

\footnotetext{
${ }^{1}$ Dosi (2006) refere-se à demanda como sinônimo de demanda de mercado.
} 
De outro lado, esse processo era facilitado, principalmente, pela contribuição dos conhecimentos empíricos - que resultaram de observações, experiências, atitudes específicas, tradição oral e escrita - e de outros conhecimentos voltados à comercialização das tecnologias.

Observa-se que enquanto as atividades de pesquisa científica e desenvolvimento de novas tecnologias eram acompanhados por melhorias provenientes do aprendizado por execução; os conhecimentos (empíricos) do ambiente da produção, por sua vez, tornaram-se o laboratório para a identificação de novas trajetórias na ciência básica.

No século $X X$, as estruturas científica, tecnológica e econômica que viabilizaram a integração entre pesquisa científica e empírica passaram a apresentar dinâmicas internas distintas (sistemas científico, tecnológico e econômico), e eram institucionalizados de diversas maneiras (Dosi, 2006) entre os países e setores industriais².

Em setores como a engenharia mecânica, por exemplo, a institucionalização das atividades de pesquisa científica e empírica não promoveu rupturas na forma como eram realizadas as melhorias $e$ desenvolvimentos tecnológicos. Naquele setor, dificilmente as atividades de pesquisa e de desenvolvimento poderiam ser dissociadas porque é frequente a incorporação de novos conhecimentos durante o processo de produção.

A existência de integração entre pesquisa científica e empírica contribuiu para o acúmulo de competências específicas e a delimitação das trajetórias tecnológicas dos setores industriais. Entretanto, nem toda tecnologia pode ser atribuída aos esforços destinados à investigação científica, assim como nem todos os resultados de uma investigação se transformarão em tecnologia.

Enquanto nas áreas de saúde e química, os investimentos e o tempo gastos em P\&D contribuíram mais para a ampliação do conhecimento científico; nas áreas de engenharias, por sua vez, os esforços na área da produção foram os principais responsáveis pela ampliação dos conhecimentos e de competências.

A demanda e a participação do Estado assumiram papel decisivo para o processo de mudança técnica dos países desenvolvidos, transformando esse

\footnotetext{
${ }^{2}$ No século $X X$, verifica-se o inicio da institucionalização do processo de pesquisa que não estava confinada à ciência básica (Mowery; Rosenberg, 1999).
} 
contexto de integração entre pesquisa científica e empírica e o desenvolvimento tecnológico ${ }^{3}$.

$\mathrm{Na}$ indústria de semicondutores dos EUA, por exemplo, a pesquisa científica e os desenvolvimentos de tecnologias no século $X X$ foram influenciados pela demanda do setor militar e do setor civil (Dosi, 2006).

No início de desenvolvimento do setor (década de 1950), o conhecimento estava relativamente desincorporado do equipamento imobilizado e incorporado às pessoas e organizações. Havia poucos esforços de P\&D, que estavam concentrados em algumas empresas de grande porte. Entretanto, o nível de conhecimento incorporado entre cientistas e empresas e a sua posição favorável na fronteira de desenvolvimento resultaram em dispersão de informações sobre processo e produto.

O mercado norte-americano - em especial a demanda do setor militar apresentou papel significativo para a difusão e a exploração comercial das inovações e a mudança técnica do setor. Além disso, a demanda do setor militar foi importante para o desenvolvimento do setor de semicondutores porque a indústria norte-americana como um todo estava estabelecendo e reforçando sua liderança tecnológica e sua presença na fronteira tecnológica.

O Estado norte-americano também apresentou papel decisivo para o processo de difusão de conhecimentos técnicos entre o setor militar e civil. As políticas públicas asseguravam o mercado para produtos mais avançados, diminuíam os riscos enfrentados por novos entrantes e criavam mecanismos para forçar a Bell Labs a disseminar suas patentes e conhecimento tecnológico para o ramo industrial no país.

Os mecanismos adotados para promover o setor de semicondutores dos EUA impulsionaram a acumulação de conhecimento interno às empresas e tornaram o processo de inovação mais rentável, refletindo em aumento do tamanho das empresas e expansão desse número de empresas de semicondutores (Dosi, 2006, p. 93) ${ }^{4}$.

\footnotetext{
3 A tese não apresenta análise aprofundada sobre políticas públicas de apoio e incentivo ao desenvolvimento do setor de máquinas.

${ }^{4}$ Essa discussão não considera a dinâmica do setor de semicondutores em relação às características do mercado de tecnologias, uma vez que o país ocupava a liderança no desenvolvimento e produção de tecnologias. Além disso, a discussão não considera como as dificuldades tecnológicas não solucionadas repercutiram em estreitamento entre o setor produtivo e de P\&D; e em vínculos estabelecidos entre setor de semicondutores e setor militar.
} 
Ao longo das décadas, o Estado reduziu a sua participação no desenvolvimento do setor de semicondutores dos EUA, à medida que as tecnologias apresentavam características técnicas mais definidas. Uma das justificativas para esse comportamento é que o processo de criação, incorporação e difusão de conhecimentos no ramo de semicondutores se tornava endógeno ao sistema econômico. Além disso, a melhorias eram realizadas de maneira mais autônoma entre as empresas, resultando em alterações na trajetória tecnológica do setor de semicondutores (Dosi, 2006).

A partir dessa breve análise sobre a indústria de semicondutores dos EUA, é possível destacar que o desenvolvimento tecnológico é realizado por empresas em função das características do ambiente em que elas atuam.

Considera-se que as empresas e setores industriais podem desenvolver diferentes rotinas ou apresentar pequenos desvios em uma trajetória tecnológica, como forma de responder à influência de variáveis externas (mercado) e internas (firmas), ou devido à emergência de outras tecnologias com caráter radical ou melhorias incrementais ${ }^{5}$.

Considera-se que o ambiente em que as empresas estão inseridas pode facilitar a identificação de trajetórias tecnológicas e a incorporação e difusão de conhecimentos entre os setores industriais.

Nas situações em que a trajetória tecnológica apresenta base de conhecimentos codificados, por exemplo, as empresas podem apresentar condições próprias para incorporar e internalizar esses conhecimentos à sua área de produção.

Nas situações em que a trajetória tecnológica apresenta mais conhecimentos tácitos, que abrange também as habilidades e competências implícitas, as empresas podem apresentar uma barreira cognitiva para incorporar e internalizar tais conhecimentos. Neste caso, o aprendizado da trajetória tecnológica dificilmente será realizado de maneira independente, 0 que reforça o papel do ambiente em que as empresas estão inseridas.

As empresas apresentam diferenças no processo de incorporação e difusão daqueles conhecimentos, seja quando a unidade de análise é o mesmo setor entre grupos de países ou quando se considera diferentes ramos de um

\footnotetext{
5 Os desvios em relação às características dos insumos, por exemplo, podem influenciar o desenvolvimento de tecnologias em outras direções.
} 
país. Há três fatores que explicam essas diferenças na criação e aprendizado e que influenciam a mudança de uma trajetória tecnológica.

Em primeiro lugar, como o conhecimento tecnológico apresenta caráter cumulativo e indivisível (Lundvall, 1988), o aprendizado de novas tecnologias ('incorporada' e desincorporada) depende da existência de habilidades e experiências prévias, que são acumuladas no ambiente interno das firmas.

Uma vez que as habilidades são internalizadas na forma de regras e de conhecimentos, torna-se relativamente difícil romper com o padrão existente. Isso porque os agentes (empresas ou setores) podem encontrar dificuldades para rever aspectos cognitivos e destruir competências internas desenvolvidas e acumuladas a partir da trajetória recente. Nesse sentido, há uma dependência em relação à trajetória tecnológica anterior (caráter path dependence) ${ }^{6}$ que dificulta o abandono de rotas pré-estabelecidas (Cohen; Levinthal, 1990; Heller, 2006).

Em segundo lugar, as condições macroeconômicas, a infraestrutura de pesquisa, as políticas de fomento e incentivo à inovação, a qualidade da mãode-obra e a influência de empresas multinacionais nos mercados em que as tecnologias serão comercializadas também podem influenciar 0 desenvolvimento de tecnologias de produtos e processos.

Em terceiro lugar, destaca-se a existência de incerteza em relação aos resultados (econômicos e extra-econômicos) do aprendizado de conhecimentos cada trajetória.

O caráter cumulativo dos conhecimentos, as condições para o seu acesso e a incerteza em relação aos resultados do conhecimento tecnológico podem dificultar a escolha e mudanças das trajetórias tecnológicas.

Além disso, o desempenho das empresas em uma trajetória tecnológica dependerá da criação de estruturas internas e mudanças organizacionais que possibilitem a incorporação de conhecimentos e, principalmente, que eles se tornem endógenos aos sistemas de produção das empresas. A criação dessas estruturas internas, por sua vez, pode demandar altos níveis de investimentos

\footnotetext{
${ }^{6} O$ conceito de path dependence pode ser explicado como "a seqüência de escolhas econômica que é condicionada, a cada momento, pela situação criada por escolhas anteriores e que, ao mesmo tempo, tende a reforçá-las sem que esta consequência seja considerada pelos agentes que tomam decisões" (HELLER, 2006, p. 260).
} 
e muito tempo. Os custos necessários para incorporar conhecimentos (de produto ou processo) e transformá-la em tecnologias comercialmente lucrativa podem tornar os métodos para transferência de tecnologia pouco viável financeiramente.

Os setores industriais ou empresas podem apresentar mecanismos para lidar com essas condições e viabilizar a aquisição de conhecimentos. Nas últimas décadas, os setores adotaram estratégias de integração com fornecedores e usuários da cadeia, fusão com empresas líderes do setor, a formação de joint ventures ou pesquisa conjunta com instituições de pesquisa ${ }^{7}$.

O ambiente institucional ${ }^{8}$ em que os agentes estão inseridos também pode determinar que os avanços tecnológicos sejam realizados de maneira mais rápida em alguns setores do que em outros (Klevorick et al, 1995). Nas ultimas décadas, a análise das condições políticas e macroeconômicas, por exemplo, tem ajudado a distinguir os fatores determinantes para 0 desenvolvimento entre os países de industrialização recente ${ }^{9}$.

Acredita-se que, apesar da contribuição para a formulação de políticas, a análise de fatores no nível macroeconômico não é suficiente para explicar particularidades da mudança técnica ao nível dos setores. Além disso, em alguns casos, o grau de alcance daquelas políticas é relativamente limitado entre os segmentos industriais.

Parte-se do pressuposto de que a interação entre componentes de um Sistema Setorial de Inovação para um dado regime tecnológico pode condicionar ou viabilizar a mudança técnica de setores e empresas. Particularmente, as interações entre empresas e instituições de pesquisa podem contribuir para o desenvolvimento e melhorias de tecnologias nos setores industriais.

A próxima seção discutirá as características gerais do regime tecnológico e do Sistema Setorial de Inovação e seu papel para a mudança técnica.

\footnotetext{
7 Considera-se que as estratégias adotadas por aquelas empresas e setores industriais visando à aquisição de conhecimentos indicam que há percepção sobre a existência de diferentes trajetórias tecnológicas e a necessidade de atualização de conhecimentos.

${ }^{8} \mathrm{O}$ ambiente institucional pode abranger características econômicas, sociais e políticas que condicionam o desenvolvimento e aprendizado de tecnologias.

${ }^{9}$ As condições macroeconômicas e instrumentos de política não serão analisados em profundidade no estudo empírico e teórico da tese.
} 


\subsection{Regime tecnológico e Sistema Setorial de Inovação ${ }^{10}$}

A discussão empreendida neste trabalho considera que a mudança técnica é influenciada por características do ambiente em que os atores (empresas ou setores industriais) estão inseridos. Além disso, o regime tecnológico reunirá diferentes estratégias e condições relacionadas ao processo de criação, incorporação e difusão de tecnologias ao longo do tempo.

As estratégias tecnológicas guiam a tomada de decisão sobre as atividades inovativa e são influenciadas pelo nível e tipo de capacidades idiossincráticas ao nível da firma (Malerba; Orsenigo, 1993, p. 50-51).

As capacidades abrangem o conjunto de competências (habilidades) e ativos complementares do ambiente interno das firmas. As competências, por sua vez, assumem características que são relativamente específicas ao nível de uma empresa, podendo ser orientadas por duas dimensões: especialização ou diversificação do conhecimento-base.

À medida que as empresas de um setor internalizam essas competências, também estarão formando um conjunto de capacidades para as atividades inovativas no futuro.

O regime tecnológico pode ser definido como o ambiente que reúne diferentes condições para o desenvolvimento de tecnologias: oportunidade; apropriabilidade; grau de cumulatividade do conhecimento tecnológico e características do conhecimento base (Malerba, 2002). Esses elementos podem apresentar incentivos e limitantes para o comportamento dos agentes, assim como podem contribuir para a evolução das firmas, de tecnologias e de indústrias (Malerba; Orsenigo, 1993).

O primeiro componente do regime tecnológico são as condições de oportunidade, que se referem à facilidade que as empresas apresentam para inovar com qualquer soma de dinheiro investido em pesquisa. As condições de oportunidades podem ser caracterizadas de acordo com o seu nível (alto-

\footnotetext{
${ }^{10}$ A análise empírica e setorial da tese aponta características das trajetórias tecnológicas e descreve como usuários, fornecedores e o ambiente institucional influenciaram na escolha entre trajetórias. Considera-se que esses atores contribuem de maneira significativa para o desenvolvimento tecnológico no nível setorial e esse aspecto será ressaltado em vários trechos deste trabalho. Entretanto, a pesquisa empírica da tese optou por não analisar detalhadamente as características e a atuação de cada um desses atores e as suas interações com o setor de máquinas-ferramenta.
} 
baixo), suas fontes principais (indústrias, ciência, etc.), a pervasividade dos conhecimentos.

Um aspecto importante para entender as condições de oportunidade é a idéia de tecnologias pervasivas. Pervasividade refere-se à característica do conhecimento que se difunde e pode ser utilizado em outras áreas.

As tecnologias são pervasivas quando os conhecimentos associados à essas tecnologias apresentam sinergia com outras áreas de conhecimento e podem ser aplicados a uma variedade de produtos e mercados (Malerba; Orsenigo, 1993).

O caráter pervasivo das tecnologias pode influenciar as condições de oportunidade da seguinte maneira: quanto mais as tecnologias assumem caráter pervasivo, ou seja, os conhecimentos e suas aplicações (técnicas) podem ser incorporados por outros agentes fora do setor principal de criação daquela tecnologia, maiores serão as condições de oportunidade para o desenvolvimento e melhorias de produtos e processos.

Considera-se que há uma relação entre as estratégias de especialização ou diversificação dos conhecimentos tecnológicos, a característica pervasiva das tecnologias e as condições de oportunidade.

De maneira geral, a especialização de conhecimentos numa mesma base tem efeito sobre a ampliação de competências e o desenvolvimento de uma trajetória tecnológica.

$\mathrm{Na}$ situação em que uma parte dos conhecimentos e competências desenvolvidos são pervasivos, isto é, podem ser utilizados em outras áreas, a especialização dos conhecimentos pode viabilizar novas condições de oportunidades numa mesma área, em empresas ou setores industriais.

Vale notar que as tecnologias pervasivas estão associadas à elevada cumulatividade e à dispersão dos conhecimentos para outras áreas. Uma vez as tecnologias pervasivas são desenvolvidas, os detentores de tais tecnologias podem apresentar alta oportunidade para a diversificação dos conhecimentos de produtos, através de aplicações do conhecimento tecnológico principal para uma variedade de produtos e mercados.

As tecnologias não-pervasivas, por sua vez, estão associadas ao alto grau de cumulatividade e baixa difusão desses conhecimentos para outras áreas. Uma vez as tecnologias pervasivas são desenvolvidas, os detentores de 
tais tecnologias podem apresentar elevada especialização da base de conhecimentos.

A indústria de bens de capital apresenta um importante exemplo dessa relação entre as estratégias de especialização ou diversificação de conhecimentos, a característica pervasiva das tecnologias e as condições de oportunidade.

A formação do setor de bens de capital ${ }^{11}$ no século XIX pode ser atribuído à fabricação de máquinas a partir da estratégia de especialização dos conhecimentos em uma mesma base (mecânica) ${ }^{12}$. Naquele período, os conhecimentos e habilidades eram direcionados à resolução de problemas nas etapas de produção das máquinas-ferramenta.

Ao longo do tempo, os conhecimentos sobre tecnologias e processos apresentavam características em comum, o que permitia a sua incorporação em máquinas para outros usos. A difusão e incorporação dos conhecimentos para vários usos, por sua vez, contribuiu para a desintegração e a formação de vários ramos industriais de máquinas (Rosenberg, 1969).

A partir da estratégia de especialização de conhecimentos e subsequente expansão para outros ramos de máquinas, a indústria de bens de capital apresentou melhores condições de oportunidade para desenvolvimento de tecnologias. Ao longo do tempo, à medida que os conhecimentos em comum eram incorporados pelas empresas, os setores industriais apresentavam a diversificação das linhas de produtos.

Vale notar que as condições de oportunidade são limitadas por características de cada paradigma tecnológico e o estágio de maturação da tecnologia em cada setor (Dosi, 1988). Além disso, as oportunidades tecnológicas podem variar de acordo com as interações que as empresas apresentam com outros atores; e em função do desenvolvimento dos paradigmas sob os quais ambos os setores atuam.

O surgimento de novos paradigmas pode remodelar os padrões de oportunidades para a mudança técnica de duas maneiras: através de

\footnotetext{
${ }_{11}^{11}$ A revisão teórica sobre a indústria de bens de capital é apresentada no capítulo 3 da tese.

12 A máquina-ferramenta pode ser definida de maneira simplificada como uma máquina projetada para o trabalhar em atividades de corte e conformação de metais e outros materiais, visando a produção de peças para diferentes usos. As informações detalhadas sobre as características dos produtos e processos das máquinas-ferramenta são apresentados no capítulo 4 da tese.
} 
mudanças no escopo para potenciais inovações; e facilitando a forma como tais mudanças são realizadas no longo prazo. Neste último, os paradigmas podem gerar novas fontes de oportunidades de insumos, produtos e complementaridade tecnológicos, em especial, para outros ramos industriais (Dosi, 1988).

O segundo componente de um regime tecnológico são as condições de apropriabilidade. Essas condições podem ser definidas como possibilidades para proteger os conhecimentos de eventuais imitadores e extrair lucros das atividades inovativas (Malerba; Orsenigo, 1993).

A apropriabilidade pode ser definida como uma propriedade dos conhecimentos tecnológicos, de artefatos técnicos, do mercado e do ambiente legal que podem viabilizar as inovações (Dosi, 1988, p. 19). Além disso, os instrumentos de apropriabilidade podem proteger as inovações da imitação dos concorrentes, atuando como gerador de renda.

De maneira geral, os setores industriais podem apresentar os seguintes instrumentos para apropriabilidade: patentes e marca própria; segredo industrial; lead time (tempo decorrido entre a concepção da inovação e sua introdução no mercado); curva de aprendizado; custo e tempo requerido; e canais de comercialização e distribuição próprios;

As condições de apropriabilidade podem variar entre tecnologias de produto e processo. O estudo empírico conduzido por Levin et al (1988) destaca que os principais mecanismos para apropriar os retornos das inovações de produto são: lead time, vantagens na curva de aprendizado e esforços na área de marketing. Para as inovações de processo, os principais mecanismos de apropriação são as curvas de aprendizado, segredos e lead times (Levin et al, 88 apud Dosi, 1988, p. 19).

Outro aspecto importante é que um setor pode apresentar diferenças inter-industriais entre os instrumentos para proteger inovações e no grau geral de apropriabilidade (Dosi, 1988).

No caso da indústria microeletrônica, por exemplo, o padrão de apropriabilidade de tecnologias nucleares ${ }^{13}$ (semicondutores, computadores, e

${ }^{13}$ O termo 'tecnologia nuclear' utilizado por Dosi (1988) pode ser definido como a tecnologia principal ou central. 
telecomunicações) é uma função da P\&D cumulativa, do tempo decorrido nas economias de escala na produção e na P\&D, e das redes de marketing e de serviços.

Os setores em que aquelas tecnologias principais serão aplicadas (máquinas-ferramenta ou bens duráveis de consumo), por sua vez, apresentam outro padrão para a apropriabilidade baseado, principalmente, em características especificas aos setores.

Outra importante condição de apropriabilidade refere-se à "capacidade de internalizar ou explorar eficientemente as interfaces e sinergias entre as tecnologias nucleares' (Dosi, 1988, p. 20).

O terceiro componente do regime tecnológico é o grau de cumulatividade dos conhecimentos tecnológicos. A cumulatividade significa que as inovações que formam um conjunto de conhecimentos no presente, constituirão uma base importante para as melhorias e inovações no longo prazo (Malerba, 2002).

A cumulatividade pode se apresentar em diferentes níveis como individual, organizacional ou nível da firma. Em cada nível, há uma relação positiva entre três fatores: a existência de canais visando à troca e aprendizado de informações; a presença de habilidades e experiência na produção e o grau de cumulatividade dos conhecimentos e habilidades.

À medida que os canais para a incorporação de informações tendem a ampliar as opções sobre técnicas e tecnologias, as habilidades e experiência podem contribuir para o aprendizado, a melhoria e a difusão das técnicas e o grau de cumulatividade dos conhecimentos.

O quarto componente do regime tecnológico refere-se às características da base de conhecimento. Esse conhecimento pode ser definido como conjunto de conhecimentos e competências técnicas internas às empresas.

A base de conhecimento pode ser classificada considerando o seu grau de complexidade e a sua natureza - tácita ou codificada (Malerba, 2002).

O grau de complexidade do conhecimento remete à idéia de que há um amplo conjunto de informações provenientes do desenvolvimento científico em várias áreas de conhecimento e do desenvolvimento de habilidades para aplicar aquelas informações. A natureza tácita ou codificada da base de conhecimento, por sua vez, refere-se à existência de habilidades e 
competências que estão atrelados à base de conhecimentos técnicos e permitem o desenvolvimento e avanços nesses conhecimentos.

O grau de complexidade e a natureza da base de conhecimentos influenciam o processo de difusão e incorporação das informações entre os agentes.

O aprendizado de conhecimento complexo pode demandar a existência de mecanismos formais e informais, voltados à difusão e incorporação daquelas informações no ambiente interno às empresas.

A existência de conhecimento tácito envolve elevado nível de informações e habilidades que foram construídas por meio da experiência na produção e uso de tecnologias e na resolução de problemas.

Nesse processo de produção, por sua vez, as habilidades podem apresentar elevado nível de especificidade, o que dificulta o seu acesso por outras pessoas e empresas.

O conhecimento codificado, por sua vez, reúne informações consolidadas na forma de regras formais, manuais, contratos, entre outros. Nessa situação, a difusão e o aprendizado são relativamente mais fáceis por conta do baixo grau de especificidade das informações.

A análise dos quatro componentes do regime tecnológico (oportunidade, apropriabilidade, cumulatividade e conhecimento-base) pode fornecer uma descrição do ambiente em que as firmas operam e pode ajudar na delimitação das características da mudança técnica no longo prazo.

As tecnologias mais pervasivas, por exemplo, implicam em mais possibilidades (oportunidades) para o desenvolvimento de novos produtos. Para viabilizar essas oportunidades, as empresas e setores também precisam desenvolver uma base de conhecimentos na forma de competências.

As competências e os conhecimentos tecnológicos desenvolvidos ao longo dos anos, por sua vez, podem funcionar como instrumento de proteção de imitadores dos produtos e processos internos às empresas. Isso porque à medida que as competências são internalizadas ao nível da firma, os demais atores apresentarão mais dificuldades para acessar e se apropriar dos conhecimentos.

As tecnologias menos pervasivas refletem poucas chances para 0 desenvolvimento de novos produtos e processos, e maiores oportunidades 
para a especialização e melhorias incrementais. Além disso, os setores com tecnologia menos pervasiva podem apresentar mais dificuldade para proteger as informações de eventuais imitadores (Malerba \& Orsenigo, 1993, p. 45). Isso porque grande parte das informações acumuladas no interior das empresas ao longo do tempo tende a se difundir para outras empresas.

O regime tecnológico apresentará características distintas em nível setorial, porque cada setor apresentará uma combinação diferente de condições de oportunidade, apropriabilidade, cumulatividade e conhecimentobase.

Quando a unidade de análise é um mesmo setor em diferentes países, também é possível identificar outras características do regime tecnológico: enquanto a cumulatividade do setor apresentará similaridades entre os países; as condições de oportunidade e apropriabilidade apresentarão diferenças entre os setores industriais (Malerba \& Orsenigo, 1996).

Essa perspectiva pode ser explicada a partir da discussão sobre Sistema Setorial de Inovação (Malerba, 2002, p. 253) e sobre Padrão Setorial de criação e difusão de tecnologias.

O Sistema Setorial de Inovação pode ser definido como a combinação de agentes, as relações entre atores e as instituições de um setor que exercem influência sobre a inovação através dos setores (Malerba, 2004, p. 1). Os principais componentes de um Sistema Setorial de Inovação e produção são o conhecimento-base e processos de aprendizado; os atores e redes; e as instituições (Malerba, 2004).

De acordo com essa perspectiva, um setor pode ser caracterizado por conjunto de conhecimento-base específico, tecnologias e insumos e os processos de aprendizado.

O conhecimento-base pode ser classificado em relação ao domínio; grau de acessibilidade; e características da cumulatividade (nível e fonte de cumulatividade), que são apresentados no quadro 2.1 . 


\begin{tabular}{|c|c|c|c|}
\hline \multirow{2}{*}{ Domínio } & \multirow{2}{*}{$\begin{array}{c}\text { Grau de acessibilidade } \\
\text { (1) }\end{array}$} & \multicolumn{2}{|c|}{ Características da cumulatividade } \\
\hline & & Nível & Fonte \\
\hline $\begin{array}{l}\text { Tecnológico } \\
\text { (científico) ou de } \\
\text { aplicações para } \\
\text { usuários e a } \\
\text { demanda. }\end{array}$ & Maior ou menor. & $\begin{array}{c}\text { Tecnológico, } \\
\text { da firma ou } \\
\text { nível local }\end{array}$ & $\begin{array}{l}\text { Pode ser classificada de três } \\
\text { maneiras: } \\
\text { a) aprendizado e retornos } \\
\text { dinâmicos crescente ao nível } \\
\text { tecnológico; } \\
\text { b) capacidade organizacional; } \\
\text { c) feedback do mercado. }\end{array}$ \\
\hline
\end{tabular}

Fonte: Elaboração própria, com base em Malerba (2002, p. 252).

(1) Quanto maior o grau de acessibilidade, menor será a concentração industrial (Malerba, 2002, p. 251).

Quadro 2.1 - Características do Conhecimento-base

Outro aspecto importante do Sistema Setorial de Inovação é a participação de atores, que correspondem a todas as estruturas responsáveis pela criação, difusão e aprendizado tecnológico.

Os atores de um Sistema Setorial de Inovação interagem através de diferentes mecanismos e estão conectados por relações de mercado e nãomercado no interior desses sistemas. Além disso, os tipos de relações estabelecidas entre os agentes diferem de um Sistema Setorial para outro, em função das características do conhecimento-base, do processo de aprendizado e das características da demanda (Malerba, 2004).

Por fim, o arcabouço do Sistema Setorial também é formado por instituições, que incluem normas, rotinas, regras, leis e práticas estabelecidas. Elas podem abranger diferentes níveis de agregação tais como local, setorial ou nacional; e podem estar direcionadas a funções específicas (inserção comercial, crédito e fomento, entre outros).

Os mecanismos utilizados por essas instituições dentro de um Sistema Setorial de Inovação para desenvolver ou realizar melhorias podem ser restrição ou incentivo, de regulação formal ou de apoio informal (Malerba, 2004).

Considera-se que a participação de atores e instituições do Sistema Setorial de Inovação pode influenciar o regime tecnológico e as escolhas entre trajetórias inovativas no longo prazo.

O arcabouço sobre Sistema Setorial de Inovação remete à existência de um ambiente de seleção que influencia a dinâmica tecnológica de um setor. 
As condições de oportunidade, apropriabilidade, cumulatividade e as características do conhecimento-base representam as características do ambiente tecnológico. Além disso, os componentes do ambiente tecnológico apresentam caráter dinâmico e co-evolucionário (Malerba; Orsenigo, 1993, p. 45), o que difere entre os setores industriais (Malerba, 2002) ${ }^{14}$.

Quando são observados os segmentos de um mesmo ramo industrial, por exemplo, não há um padrão para as condições de oportunidade (Malerba, 1996). Uma justificativa para esse aspecto é que as oportunidades para inovação estão condicionadas à existência de várias trajetórias tecnológicas. Essas trajetórias, por sua vez, podem sofrer alterações ao longo do tempo, como resultado do surgimento de outros paradigmas ou por conta do desenvolvimento de competências específicas aqueles segmentos.

Nessa situação, o Sistema Setorial de Inovação pode apresentar estratégias distintas entre os segmentos, como forma de responder às condições de oportunidade.

Considera-se que os limites setoriais do sistema de inovação podem mudar em resposta a mudanças no ambiente tecnológico (Wengel; Shapira, 2001). Cumpre questionar em que medida o Sistema Setorial de Inovação pode se adaptar e contribuir para as particularidades do regime tecnológico com caráter dinâmico e co-evolucionário.

A perspectiva do Padrão Setorial de Criação e Difusão de tecnologias também pode contribuir para essa discussão sobre componentes do regime tecnológico e o Sistema Setorial de Inovação.

A tipologia de Pavitt (1984) apresenta contribuições para a discussão sobre a diversidade setorial e a produção de tecnologias ${ }^{15}$. A partir dos estudos realizados em empresas da Inglaterra no século $X X$, a tipologia classifica os setores em quatro categorias: dominado por fornecedor; intensivo em escala; fornecedor especializado; e baseado em ciência. O quadro 2.2 resume as características do padrão setorial de inovação da Tipologia de Pavitt.

\footnotetext{
${ }^{14}$ Nos ramos da indústria química, por exemplo, os mecanismos utilizados para o acesso e aquisição de novos conhecimentos têm contribuído para as rupturas e desenvolvimento de trajetórias tecnológicas. Como resultado, verificam-se importantes avanços na área de biotecnologia e saúde. Na indústria de máquinas, por sua vez, as escolhas entre trajetórias são relativamente menos disruptivas, principalmente, porque estão apoiadas por atividades de resolução de problemas ao nível da firma e o acúmulo de conhecimento-base na área mecânica.

${ }^{15}$ Essa discussão será retomada e aprofundada na seção 3.3 da tese, na análise sobre o setor bens de capital.
} 


\begin{tabular}{|c|c|c|c|c|c|}
\hline \multirow{3}{*}{\multicolumn{2}{|c|}{$\begin{array}{c}\text { Características principais das } \\
\text { categorias }\end{array}$}} & \multicolumn{4}{|c|}{ Categorias da firma } \\
\hline & & \multirow[b]{2}{*}{$\begin{array}{c}\text { Dominada pelo } \\
\text { fornecedor }\end{array}$} & \multicolumn{2}{|c|}{ Intensiva em produção } & \multirow{2}{*}{$\begin{array}{l}\text { Baseada em } \\
\text { ciência }\end{array}$} \\
\hline & & & $\begin{array}{c}\text { Intensiva em } \\
\text { escala }\end{array}$ & $\begin{array}{l}\text { Fornecedores } \\
\text { especializados }\end{array}$ & \\
\hline \multicolumn{2}{|c|}{ Atividades nucleares típicas } & $\begin{array}{l}\text { Agricultura, } \\
\text { construção civil, } \\
\text { serviços privados, } \\
\text { manufatura } \\
\text { tradicional. }\end{array}$ & $\begin{array}{l}\text { Materiais volumosos } \\
\text { (Aço, Vidro); montagem } \\
\text { (bens de consumo } \\
\text { duráveis e autos) }\end{array}$ & $\begin{array}{l}\text { Maquinaria; } \\
\text { instrumentos de } \\
\text { precisão. }\end{array}$ & $\begin{array}{c}\text { Eletrônico/ } \\
\text { Elétrico; Químico }\end{array}$ \\
\hline \multirow{3}{*}{$\begin{array}{l}\text { Fatores } \\
\text { determinantes } \\
\text { das atividades } \\
\text { tecnológicas }\end{array}$} & $\begin{array}{l}\text { Fontes de } \\
\text { tecnologia }\end{array}$ & $\begin{array}{l}\text { Extensão dos } \\
\text { serviços de } \\
\text { pesquisa dos } \\
\text { fornecedores }\end{array}$ & $\begin{array}{l}\text { Engenharia de } \\
\text { produção dos } \\
\text { fornecedores }\end{array}$ & $\begin{array}{c}\text { Projeto e } \\
\text { desenvolvimento } \\
\text { pelos usuários }\end{array}$ & $\begin{array}{l}\text { P\&D; ciência } \\
\text { pública; } \\
\text { Engenharia de } \\
\text { produção. }\end{array}$ \\
\hline & \begin{tabular}{|l} 
Tipos de \\
usuários
\end{tabular} & Sensível ao preço & Sensível ao preço & $\begin{array}{c}\text { Sensível ao } \\
\text { desempenho }\end{array}$ & Misto \\
\hline & $\begin{array}{l}\text { Mecanismos de } \\
\text { apropriação }\end{array}$ & $\begin{array}{c}\text { Não técnico } \\
\text { (marcas, } \\
\text { marketing, } \\
\text { propaganda, } \\
\text { aparência estética) }\end{array}$ & $\begin{array}{l}\text { Segredo e know-how de } \\
\text { processo; defasagens } \\
\text { técnicas; patentes; } \\
\text { economias dinâmicas } \\
\text { de aprendizado. }\end{array}$ & $\begin{array}{c}\text { Know-how de projeto; } \\
\text { conhecimento dos } \\
\text { usuários; patentes. }\end{array}$ & $\begin{array}{c}\text { Know-how de } \\
\text { P\&D; patentes; } \\
\text { segredo e know- } \\
\text { how de processo; } \\
\text { economias } \\
\text { dinâmicas de } \\
\text { aprendizado. }\end{array}$ \\
\hline \multicolumn{2}{|c|}{ Trajetórias tecnológicas } & $\begin{array}{l}\text { Redução de } \\
\text { custos }\end{array}$ & $\begin{array}{l}\text { Redução de custos (no } \\
\text { projeto do produto) }\end{array}$ & Projeto de produto & Mista \\
\hline \multirow{4}{*}{$\begin{array}{l}\text { Características } \\
\text { mensuradas }\end{array}$} & $\begin{array}{l}\text { Fontes de } \\
\text { tecnologia }\end{array}$ & Fornecedores & Interna; Fornecedores & Interna; Clientes & $\begin{array}{c}\text { Interna; } \\
\text { Fornecedores }\end{array}$ \\
\hline & $\begin{array}{l}\text { Inovação } \\
\text { relativamente } \\
\text { predominante }\end{array}$ & Processo & Processo & Produto & Mista \\
\hline & \begin{tabular}{|l} 
Tamanho \\
relativo das \\
firmas \\
inovadoras
\end{tabular} & Pequeno & Grande & Pequeno & Grande \\
\hline & $\begin{array}{l}\text { Intensidade e } \\
\text { direção da } \\
\text { diversificação } \\
\text { tecnológica }\end{array}$ & Baixa, vertical & Alta, vertical & Baixa, concêntrica & $\begin{array}{l}\text { Baixa, vertical / } \\
\text { Alta, concêntrica }\end{array}$ \\
\hline
\end{tabular}

Quadro 2.2 - Trajetórias tecnológicas setoriais: determinantes, direções e características mensuradas

O conjunto de características apresentados no quadro acima remete à idéia de que cada categoria industrial apresenta um padrão para a produção de inovações.

O estudo de Pavitt (1984) considera que cada setor apresenta diferenças quanto à importância relativa das inovações de produto e de processo; quanto às fontes de tecnologia de processo; e em relação ao tamanho e ao padrão de diversificação tecnológica das firmas. 
A tipologia de Pavitt (1984) é importante para a compreensão sobre as fontes principais de inovação através dos setores, mas não tem o propósito de analisar os determinantes do processo de difusão de inovações inter e intrasetores e as características da mudança técnica ao longo do tempo.

Considera-se que o processo de criação de conhecimentos é determinado, principalmente, por critérios econômicos como níveis e mudança nos preços relativos; a capacidade de redução dos custos da nova tecnologia; e níveis e mudanças na demanda (Dosi, 1988).

A demanda influencia a busca tecnológica, por meio de estímulos, limitação e seleção de novos paradigmas (Dosi, 1988). Por outro lado, também pode existir forte resistência em aceitar novos estímulos do mercado, que tendem a mudar os imperativos tecnológicos e a direção daquele processo de busca e seleção.

No momento seguinte, em que um paradigma tecnológico foi consolidado, a difusão de novas técnicas e conhecimentos dependerá de características do regime tecnológico no nível setorial.

As condições de oportunidade e apropriabilidade motivam os agentes econômicos a explorar outras tecnologias visando à geração de renda (Dosi, 1988, p. 22). No longo prazo, essas condições podem influenciar a criação de especificidades tecnológicas ao nível das empresas e daqueles segmentos industriais. Além disso, as condições de oportunidades e apropriabilidade determinam que a trajetória de mudança técnica assuma uma direção em detrimento de outras.

Os segmentos industriais podem adotar estratégias visando à especialização ou diversificação de sua base de conhecimentos, considerando características da demanda e as trajetórias tecnológicas recentes e potenciais.

As demandas exercem maior influência sobre estratégias de especialização ou diversificação e a mudança tecnológica ao nível de empresas e segmentos. Entretanto, as escolhas realizadas no passado em relação às trajetórias tecnológicas podem contribuir para a continuidade do padrão de especialização ou diversificação dos conhecimentos.

O desenvolvimento inicial setor de máquinas-ferramenta, por exemplo, esteve apoiado na demanda de outros setores industriais que precisavam resolver problemas no processo de produção. 
Considera-se que as trajetórias tecnológicas escolhidas pelas empresas daquele setor em diferentes países refletiram em padrão de especialização ou diversificação dos conhecimentos.

Para viabilizar o desenvolvimento técnico das máquinas ao longo das décadas, as empresas fabricantes de máquinas contavam com elementos do Sistema Setorial de Inovação que influenciavam a forma como os conhecimentos eram difundidos, incorporados e internalizados no interior das empresas. Além disso, o conjunto de oportunidades tecnológicas viáveis para as empresas com produção de máquinas aumentava por conta da característica pervasiva da base de conhecimentos em mecânica.

Considerando a discussão teórica realizada até o momento, parte-se do pressuposto de que os Sistemas Setoriais podem contribuir para a criação de conhecimentos e, principalmente, para a difusão e mudanças das tecnologias pervasivas ou não. Esse argumento será discutido para o caso especifico do setor de máquinas-ferramenta ${ }^{16}$. 0 próximo capítulo analisa as características do desenvolvimento industrial e tecnológico do setor de máquinas, enfatizando os elementos e os atores envolvidos na mudança técnica.

\footnotetext{
${ }^{16}$ A tese destaca a relevância do arcabouço sobre Sistema Setorial de Inovação e sua relação com o regime tecnológico. Entretanto, a revisão teórica e empírica sobre o setor de máquinas-ferramentas discute as características das interações entre dois atores do Sistema Setorial de máquinas-ferramenta: empresas e grupos de pesquisa.
} 


\section{Capítulo 3 - Desenvolvimento e mudança técnica na indústria de bens de capital}

O terceiro capítulo analisa as características do desenvolvimento industrial e tecnológico da indústria de bens de capital, enfatizando os elementos e os atores envolvidos na mudança técnica no setor.

Primeiramente, serão apresentados os determinantes da formação da indústria e o seu papel para o desenvolvimento econômico nas economias capitalistas no século XIX e XX.

Posteriormente, serão discutidos os padrões e rupturas no desenvolvimento de tecnologias da indústria.

Nesse sentido, o capítulo direciona a discussão para três elementos que contribuem para diferenças na direção e velocidade da mudança técnica entre os setores de máquinas: a origem e especialização do setor; a alteração em seu padrão de desenvolvimento a partir da inserção da microeletrônica; e as características de seu regime tecnológico.

\subsection{A indústria de bens de capital e o desenvolvimento econômico}

O surgimento da indústria de bens de capital está historicamente relacionado ao processo de industrialização verificada nos países desenvolvidos, em especial, Inglaterra e EUA.

Em grande medida, a industrialização desses países foi influenciada pela velocidade com que a mudança técnica foi difundida do seu ponto de origem, na indústria de bens de capital, para outros setores da economia (Rosenberg, 1963).

$\mathrm{Na}$ fase inicial do processo de industrialização, a principal função das novas tecnologias era viabilizar as invenções em diferentes áreas da economia. As invenções de novos produtos e processos, uma vez concebidos, só poderiam garantir participação nas economias industriais após o surgimento de uma máquina que pudesse resolver os problemas técnicos e mecânicos que a invenção pudesse demandar (Marx, 1983). Nesse cenário, a criação da 
indústria de bens de capital ajudou a institucionalizar as pressões para a adoção de novas tecnologias (Rosenberg, 1970).

A inserção dessas tecnologias ao ambiente econômico e industrial, por sua vez, estava condicionada à existência de fatores econômicos, intrínsecos ao desenvolvimento da indústria de máquinas. Destaca-se a capacidade para a redução de custos das novas tecnologias incorporadas às máquinas e 0 potencial para economizar mão-de-obra (Rosenberg, 1970). Por fim, as máquinas também deveriam garantir o desenvolvimento e a eficiência na produção, com ganhos de produtividade no processo de industrialização.

As características assumidas por esse setor desde a fase inicial de seu desenvolvimento contribuíram para a rapidez do processo de industrialização e o crescimento econômico no século XIX. Por outro lado, havia um conjunto de fatores que influenciaram a direção da mudança técnica e o sucesso ou fracasso das empresas fabricantes de máquinas entre os países.

Nas economias industrializadas dos EUA e Inglaterra, a proporção de inovações originadas no setor de máquinas e ferramenta e a sua capacidade para produzir máquinas de baixo custo, repercutiram na geração e acumulação de renda nacional (Furtado, 2003).

Nesses países, a primeira fase de introdução de uma indústria de máquinas a partir de meados do século XVIII contribuiu para transformações tecnológicas estruturais; ajudou na absorção do excedente de mão-de-obra decorrente da desorganização das atividades artesanais; e conservava o ritmo de acumulação de capital (Furtado, 2003, p. 91).

Nos países de industrialização recente, a aquisição de tecnologias determinava mudanças na produtividade, o aumento da renda e resultava em ganhos econômicos. Mas as tecnologias contribuíam, principalmente, para a criação de novas formas de consumo e a variabilidade da demanda nacional (Prebisch, 1973). Nesse contexto Dosi (2006, p. 49) também ressalta:

"Nas sociedades em que os conflitos industriais e os relativos à distribuição de renda são características estruturais, a colocação de máquinas no lugar de mão-de-obra deve ser determinante no processo de busca de novas tecnologias".

O perfil agrário-exportador daqueles países e o fraco (ou nulo) encadeamento entre ciência e tecnologia não possibilitavam o surgimento de 
um setor de máquinas nos moldes das economias capitalistas (Prebisch, 1973; Furtado, 2003).

Além disso, a demanda por produtos finais não era atendida pela produção nacional, mas pela importação de máquinas e tecnologias provenientes de outros países. As importações de máquinas, por sua vez, eram viabilizadas por saldos decorrentes da exportação de produtos não manufaturados e isso repercutia negativamente sobre a sua estrutura produtiva e industrial no longo prazo (Prebisch, 1973).

Esse processo resultou em duas características para os países de industrialização recente: modificação do modo como a população ativa se distribuía para a produção e consumo dos novos bens (Furtado, 2003); e consolidação de uma dinâmica de desenvolvimento tecnológico distinta daquela verificada nos países industrializados (Prebisch, 1973); Furtado, 2003).

Um fator importante é que a taxa de mudança técnica estava completamente separada dos bens de capital (Rosenberg, 1970) naqueles grupos de países. À medida que o desenvolvimento e as melhorias foram institucionalizados por empresas, o padrão para desenvolver, transferir e adaptar tecnologias seguiu direções distintas, mesmo entre países desenvolvidos como os EUA e a Inglaterra.

Nesses países industrializados, as características do desenvolvimento do setor de bens de capital resultaram em mudança técnica endógena ao sistema econômico. As empresas contavam com um estímulo (interno aos setores industriais) para melhorar as técnicas de produção e atender a demanda por produtos locais e desenvolveram uma base de conhecimentos acumulados ao longo do tempo.

Nos países de industrialização recente, o setor de máquinas não apresentava as mesmas condições. Em grande medida, não havia o acúmulo de conhecimentos tecnológicos ou a escolha por técnicas adequadas ao seu contexto industrial. E a aquisição de máquinas via importação era o mecanismo que poderia promover o desenvolvimento técnico no longo prazo.

Desse modo, o desenvolvimento da indústria de bens de capital ganha conotação distinta desde as fases iniciais da industrialização, por conta das características do contexto histórico, econômico e social entre os países. 
De um lado, o desenvolvimento dos segmentos industriais consolidou características estruturais do desenvolvimento e acumulação de renda nacional naqueles países (Prebisch, 1973; Furtado, 2003). De outro lado, o processo de criação e transferência de tecnologia apresentou características distintas entre os ramos industriais e países. Esse aspecto pode ser justificado, principalmente, pela dependência de tecnologias transferidas dos países desenvolvidos.

Esse conjunto de fatores pode ajudar a compreender porque a indústria de bens de capital iniciou e ampliou suas atividades industriais em alguns países, enquanto outros desenvolveram seu parque industrial posteriormente.

A próxima seção discutirá as principais características da indústria de bens de capital, considerando seu padrão e as rupturas do desenvolvimento técnico ao longo das décadas. É importante entender como esse processo de desenvolvimento tecnológico foi viabilizado nas economias capitalistas desenvolvidas e quais as características da mudança técnica no longo prazo. 


\subsection{Padrões e rupturas no desenvolvimento tecnológico da indústria de bens de capital}

\subsubsection{A origem e especialização do setor}

A indústria de bens de capital surgiu paralelamente às principais inovações em outros ramos da economia, como forma de viabilizar tais invenções e difundi-las para outros setores e usos.

Antes da consolidação de uma indústria de máquinas, a primeira transformação na base técnica para a produção de bens pode ser caracterizada pelo surgimento de um setor de ferramentas, que combinava trabalho físico com as peças utilizadas na realização desse trabalho (Hitomi, 1994, p. 121).

As atividades de produção estavam interligadas e apresentavam exigências diferentes para os trabalhadores (Marx, 1983, p. 464). Nesse sentido, destaca-se a atuação de muitos trabalhadores parciais que executavam diferentes operações alternadamente (Marx, 1983).

Essas características, por sua vez, repercutiam na criação de competências internalizadas por esses artesãos e criaram uma 'forma de trabalhar' que se tornou intrínseca ao processo de produção de máquinas.

Embora as novas técnicas contribuíssem pouco para a diversificação do conhecimento-base, essas técnicas estavam apoiadas pelo domínio sobre o uso de grandes quantidades de material barato e contavam com maior tempo para o seu desenvolvimento e a sua difusão (Rosenberg, 1974).

Ao mesmo tempo em que ocorria a expansão da indústria mecanizada e a sua inserção em novos ramos industriais, havia relativa inabilidade dos fabricantes de máquinas para produzir máquinas que poderiam desempenhar funções de acordo com requerimentos especiais e especificações dos usuários (Rosenberg, 1963).

Em grande medida, a mão-de-obra nos segmentos de artesanato e manufatura não poderia acompanhar a característica 'semi-artística' e o simultâneo conhecimento técnico exigido na produção do setor (Marx, 1983).

Nesse sentido, somente após a realização de algumas transformações em outros ramos da indústria - como o sistema de transportes e comunicações 
- e a utilização de outros insumos como metal, um novo modo de produção foi viabilizado para as empresas de máquinas (Marx, 1983).

Ao longo do tempo, a indústria de bens de capital apresentou estágios de desenvolvimento que refletiam o tamanho do mercado para tais máquinas e o acréscimo de habilidades técnicas e conhecimento (Rosenberg, 1963).

As empresas de máquinas estavam subordinadas às fábricas especializadas na produção de bens finais, em especial, da indústria têxtil (Rosenberg, 1963), o que foi significativo para o desenvolvimento de habilidades industriais nas máquinas. As habilidades adquiridas na indústria de origem, por sua vez, tinham aplicação direta para a solução de problemas de produção daquelas indústrias (Rosenberg, 1963).

Havia um processo de aprendizado envolvido na produção da maquinaria, o que conduzia a um alto grau de especialização da produção de um número relativamente pequeno de processos produtivos similares, destinados para algumas indústrias (Rosenberg, 1970).

As experiências dos países desenvolvidos indicam que as experiências de aprendizado no projeto e uso de máquinas foram significativos para o dinamismo tecnológico daqueles países (Rosenberg, 1970).

Em países como a Inglaterra e os EUA, havia um padrão para a criação e realização de melhorias técnicas na indústria de máquinas. De maneira geral, os problemas observados na esfera produtiva demandavam a fabricação de uma nova máquina de acordo com certas especificações. As empresas de máquinas adaptavam continuamente seus produtos aos requerimentos tecnológicos e ampliavam o alcance desses produtos, em resposta às especificações técnicas das empresas de outros setores (Rosenberg, 1963).

Esse processo de modificação das máquinas, por sua vez, estava baseado na criação e assimilação de competências em novas tecnologias e sua contínua adaptação ao longo do tempo (Rosenberg, 1963).

O setor trabalhava com o mesmo conjunto de conhecimentos na manipulação do metal - refino e fusão de minérios de metal, fundição e a transformação do metal em formas finais. Por conta desse fator, as empresas puderam aproveitar a complementaridade no processo de fabricação e adaptação de máquinas para diferentes naturezas e usos finais (Rosenberg, 1963). 
Outro aspecto importante é que havia um conjunto de problemas compartilhados por vários segmentos usuários das máquinas, e que estava associado com a introdução de melhorias técnicas (transmissão de energia, serviços de controle, mecanismos de alimentação, redução da fricção) ou com as propriedades do metal.

O conjunto de conhecimentos comuns relacionados ao processo e os problemas compartilhados em uma mesma base tecnológica são elementos característicos da convergência tecnológica (Rosenberg, 1963). Esse processo de convergência compreendia habilidades similares, técnicas e recursos em comum que substituíam as seqüências verticais individuais e que tendiam a ser mais específicas nas fases iniciais de desenvolvimento da indústria de bens de capital (Rosenberg, 1963).

A indústria de máquinas-ferramenta foi determinante para esse processo de convergência tecnológica (Tauille, 1993) e para o aprendizado e difusão de novas tecnologias.

O setor de máquinas-ferramenta surgiu em 1840, como resultado de transformações no processo de fabricação das ferramentas. Dentre essas transformações, a principal é que as tarefas realizadas com trabalho físico passam a ser realizadas com o auxílio de máquinas, visando o aumento da produtividade e a eficiência do trabalho (Tauille, 1993).

As máquinas-ferramenta apresentavam três componentes: uma impulsionadora convertendo um tipo de energia para energia mecânica; um $\underline{\text { transmissor transmitindo uma força motriz para o local de trabalho; e a unidade }}$ de usinagem conduzindo o trabalho mecânico (Marx apud Hitomi, 1994, p. 121).

No início do desenvolvimento da indústria de bens de capital, as máquinas-ferramenta utilizavam um conjunto de princípios em comum, homogeneizando a base técnica que foi denominada 'base técnica eletromecânica' (Tauille, 1993). Esses conhecimentos em comum eram incorporados por outros segmentos industriais, possibilitando o surgimento de máquinas voltadas à produção de outras máquinas.

Nesse cenário, as empresas de máquinas-ferramenta reuniam processos que poderiam ser empregados em um conjunto de indústrias tecnologicamente não relacionadas. As habilidades adquiridas na indústria de 
origem, por sua vez, tinham aplicação direta para os problemas de produção em outras indústrias e eram difundidas para a produção de outros tipos de máquinas de outros setores industriais.

A convergência de tecnologias que viabilizou o surgimento do setor de máquinas-ferramenta apresentou importantes contribuições também para 0 desenvolvimento de setores de bens de consumo duráveis (máquinas de costura, bicicletas, etc.).

Um aspecto importante para o desenvolvimento do setor de máquinas é que havia uma interdependência entre três elementos do sistema máquinasferramenta (Rosenberg, 1969):

- Elementos estruturais: tinham a função de suportar o trabalho e as ferramentas;

- Elementos de transmissão: eram responsáveis pelos movimentos visando o molde das peças; e

- Elementos de controle: ajustavam os elementos estruturais e controlavam o funcionamento da transmissão.

No início de uma invenção, as melhorias realizadas em um dos componentes desse sistema interdependente criavam desequilíbrios entre as demais operações das máquinas-ferramenta. Esses desequilíbrios, por sua vez, funcionavam como estímulos para mudanças nas outras partes do sistema.

Desse modo, a interdependência e a sequência de melhoramentos constituíram importante fonte de mudança técnica nas máquinas-ferramenta (Rosenberg, 1969).

O padrão de produção das tecnologias nos EUA e Inglaterra apresentava outra característica em comum. De maneira geral, uma firma desenvolvia uma nova técnica ou processo em resposta a um problema em uma particular indústria. Posteriormente, quando a técnica torna-se aplicável a outras categorias de máquinas, essa técnica era transferida para a indústria atual pela firma que desenvolveu a técnica (Rosenberg, 1970).

Inicialmente, as empresas trabalhavam de forma subordinada às fábricas especializadas na produção de bens finais e que eram usuários das 
máquinas ${ }^{17}$. Mas a necessidade de resolver problemas técnicos visualizados na introdução de um novo produto ou processo determinava a realização de atividades exploratórias na área da produção. As soluções e melhorias obtidas nessas atividades, por sua vez, apresentavam aplicação imediata também para outros ramos de produtos relacionados, que utilizavam a mesma base técnica (Rosenberg, 1963).

Nesse sentido, as empresas fabricantes de máquinas daqueles países se tornaram especializadas mais em processos do que em produtos; e o centro de transmissão desses conhecimentos era a firma individual (Rosenberg, 1970).

Além disso, os conhecimentos técnicos eram difundidos, principalmente, por meio do ramo de máquinas e ferramentas, e apresentavam alta pervasividade por conta das transformações numa mesma base de conhecimentos.

A partir dessa breve discussão é possível ressaltar que o segmento de máquinas-ferramenta foi o principal responsável por transformações no processo de produção da indústria de bens de capital porque reunia os requerimentos para a produção de uma seqüência de máquinas.

A partir do final do século XIX (entre 1880 e 1910), o crescimento da demanda por máquinas com características específicas e direcionadas para vários segmentos industriais implicou em modificações no desenvolvimento técnico da indústria de bens de capital.

As melhorias em produtos e processos passaram a avançar em direções distintas, principalmente, nos setores que apresentavam mais gargalos na área de produção. Como consequência, as máquinas destinadas a diferentes usos passam a ser fabricadas por segmentos industriais específicos.

O crescimento do número de empresas com elevado nível especialização determinou a desintegração vertical da indústria de bens de capital e a consolidação de outros ramos industriais. A desintegração vertical pode ser definida como processo em que as sequencias individuais na

\footnotetext{
17 Os usuários das máquinas-ferramenta exercem papel importante para as melhorias das máquinas desde o início do desenvolvimento do setor de máquinas-ferramentas. A tese reconhece a relevância das relações usuário-produtor para o desenvolvimento técnico do setor de máquinas, mas optou por apresentar discussão teórica sobre a relação entre fabricantes de máquinas e instituições de pesquisa.
} 
produção de um produto passam ser realizadas por firmas separadas (Rosenberg, 1963).

A convergência tecnológica e a desintegração vertical são fenômenos paralelos que conferem dinamismo ao desenvolvimento e aprendizado de técnicas na indústria de bens de capital no século XIX e XX.

A mudança técnica na indústria de bens de capital foi viabilizada por transformações no contexto em que era realizado o desenvolvimento das máquinas. E a velocidade das melhorias foi acentuada pela presença da convergência tecnológica e especialização da produção, contribuindo significativamente para o crescimento econômico do setor de máquinas.

É importante destacar duas consequências da desintegração vertical verificados na indústria de bens de capital: os avanços tecnológicos eram obtidos num ritmo mais acentuado em alguns segmentos em detrimento de outros; e essas alterações contribuíam para desvios na trajetória tecnológica dos segmentos.

Ao longo do tempo, a ciência passou a exercer papel mais importante na direção das atividades inovativas (Rosenberg, 1974) em detrimento do papel atribuído ao estoque de conhecimento interno às empresas. Além disso, essas atividades internas eram realizadas de maneira irregular e com elevada incerteza.

Vale notar que os mecanismos para a difusão, incorporação e a adaptação das tecnologias, uma vez desenvolvidas, eram relativamente distintos entre a Inglaterra e EUA (Rosenberg, 1970). Nesse sentido, os países não responderam da mesma forma às alterações no modo de produção.

Nos EUA, a especialização da produção era um mecanismo voltado para a acumulação de competências. Ao longo do tempo, as empresas diversificaram os modelos de máquinas numa mesma base técnica, contribuindo para a consolidação de outros segmentos industriais.

$\mathrm{Na}$ Inglaterra, a especialização se tornou o objetivo final dos fabricantes de máquinas, não o meio para a fabricação de máquinas para vários usos. As empresas de máquinas estavam mais preocupadas com aspectos técnicos dos produtos - máquinas mais artesanais, sem relação direta do ponto de vista da natureza e uso final - do que com o processo produtivo (Rosenberg, 1970) 
Em meados do século XIX, as características assumidas pela demanda e a interação entre os fabricantes de máquinas, seus consumidores e fornecedores (Rosenberg, 1970) determinaram um perfil de produção de máquinas muito customizadas, o que dificultava sua aplicação para outros segmentos industriais da Inglaterra.

Os usuários das máquinas na Inglaterra impuseram suas preferências para os fabricantes das máquinas, através de especificações muito detalhadas, como condição para o cumprimento dos contratos. Em muitos casos, a variação no projeto não apresentava uma explicação funcional e era resultado de acidentes históricos.

As iniciativas dos usuários das máquinas refletiram em um tipo de transmissão de tecnologias em que o produtor de máquinas assumia papel mais passivo e adaptativo do que ativo e introdutor de melhorias (Rosenberg, 1970). Esses fabricantes das máquinas da Inglaterra, por sua vez, não apresentavam rigor na produção de tais máquinas com alto grau de customização e não havia preocupação com a padronização dos modelos, o que dificultava a adoção de tecnologias e a organização do processo de produção.

Outro aspecto importante é que as empresas fabricantes de máquinas da Inglaterra não apresentavam uma boa integração de suas operações com aquelas desenvolvidas por seus principais fornecedores (como ocorria entre as empresas de máquinas e os fornecedores dos EUA). Esse fator pode ser justificado seja porque os produtores não confiavam no cumprimento de contratos, ou por conta das dificuldades técnicas provenientes da produção de máquinas que demandavam base de conhecimentos muito específicos.

Nesse cenário, muitas das especificações limitavam a exploração de tecnologias e o surgimento de novas técnicas das máquinas na Inglaterra (Rosenberg, 1970). E esse aspecto apresentou implicações negativas tanto para a eficiência na produção de máquinas, como para a habilidade em gerar inovações no longo prazo (Rosenberg, 1970).

Por conta desses fatores, é possível concluir que no século XIX o ambiente institucional influenciava o processo de pesquisa e desenvolvimento das máquinas em caminhos diferentes nos dois países. 
A partir do século $X X$, algumas transformações repercutiram na intensificação do processo de industrialização dos EUA e Inglaterra, e determinaram picos de crescimento da demanda por máquinas em vários ramos da indústria de bens de capital.

Em primeiro lugar, a inovação na fonte de insumos usados na indústria de bens de capital determinou mudanças em suas características estruturais, com o re-projeto dos componentes da máquina-ferramenta - elementos estrutural, transmissão e de controle (Rosenberg, 1963, p. 441).

A introdução das ligas de aço, em substituição ao aço carbono, como principal insumo para produção das máquinas possibilitou a fabricação de máquinas mais rápidas, mais pesadas e com instrumentos mais rígidos e resistentes a altas temperaturas e pressão (Rosenberg, 1963). Além disso, essas transformações também permitiram maior habilidade na manipulação de ferramentas de corte e a ampliação do escopo de suas operações e utilização em novos usos (Rosenberg, 1963).

Em segundo lugar, as mudanças na organização do trabalho com o paradigma da produção fordista, no início do século $X X$, influenciaram 0 desenvolvimento técnico da indústria de máquinas.

Nos EUA, as melhorias realizadas por empresas de máquinas não estavam orientadas apenas à resolução de problemas técnicos, embora esse aspecto ocupasse papel significativo no nível de investimentos direcionado à inovação.

Os conhecimentos desenvolvidos e ampliados a partir do processo de resolução de problemas técnicos resultaram em melhores condições técnicas e habilidades para atender ao aumento da escala e o escopo demandados pelo setor automobilístico. Além disso, a solução de problemas técnicos do setor de máquinas dos EUA apresentou algumas transformações com o surgimento de novas áreas de conhecimento e a inserção na base de conhecimentos da indústria de máquinas.

$\mathrm{Na}$ Inglaterra, a ausência de padronização dificultou o processo de adoção de tecnologias e a organização do processo de produção das empresas do setor (Rosenberg, 1970). Como resultado, a indústria de máquinas da Inglaterra não estava bem desenvolvida e em condições para efetuar a transferência de tecnologias voltadas aos requerimentos do 
paradigma da produção em massa em virtude do alto nível de customização de suas máquinas.

De maneira geral, a convergência tecnológica, as melhorias dos insumos disponíveis para a produção de máquinas e as exigências de produção em massa contribuíram para o dinamismo de segmentos da indústria de bens de capital. Entretanto, a base técnica eletromecânica impunha alguns limites às melhorias incrementais de algumas máquinas.

Em segmentos como o de máquinas-ferramenta, por exemplo, as empresas utilizavam as experiências acumuladas ao longo do tempo para a produção de máquinas em pequena escala. Além disso, as externalidades geradas durante o processo de produção e com o uso de novas fontes de insumos ampliavam o acervo de conhecimentos na produção de máquinas.

Como os conhecimentos (codificados, e principalmente, os conhecimentos tácitos) gerados a partir da convergência transbordavam para outras áreas de conhecimento, as empresas do setor de máquinas passaram a apresentar alterações no caráter da mudança técnica.

Desse modo, a convergência tecnológica da indústria de bens de capital tornou-se pré-condição para o aprendizado dos novos conhecimentos provenientes de outras áreas.

Os países que desenvolveram sua estrutura industrial baseada na convergência de conhecimentos tecnológicos, apresentavam base técnica de conhecimentos e competências acumulados. Esse fator, por sua vez, possibilitava o desenvolvimento de mecanismos para a criação e difusão de informações técnicas em produtos e processos.

À medida que esses conhecimentos sobre técnicas se tornaram mais específicos, e seu acesso tornou-se relativamente complexo entre os setores industriais ou mesmo na presença de novas trajetórias tecnológicas, aqueles países puderam consolidar sua estrutura industrial.

Esse conjunto de fatores representa um padrão histórico de desenvolvimento da indústria de bens de capital e pode explicar a dinâmica de desenvolvimento da indústria. A próxima seção analisa as características do desenvolvimento do setor de máquinas a partir de meados do século $X X$, com a inserção de formas de automação entre os setores industriais e entre os países desenvolvidos. 


\subsubsection{Automação e desenvolvimento tecnológico}

Essa seção discutirá a origem e principais características do processo de automação da produção, considerando seus efeitos para a evolução da indústria de máquinas.

No século $X X$ a indústria de bens de capital passou a incorporar novas tecnologias de produto e processo, que acompanhavam as exigências por eficiência produtiva nas principais economias capitalistas (Bastos, 1999, p. 190).

O termo automação foi cunhado em 1936, por D. S. Harder, funcionário da empresa General Motors Corporation, para designar a "transferência de partes de trabalho entre as máquinas num processo de produção, sem a utilização de força humana". Em 1955, o consultor J. Dielbold citou em seu livro sobre automação que o "termo pode ter dois significados: a) regulação automática por feedbacks e b) integração de certo número de máquinas" (Hitomi, 1994, p. 122). (tradução)

A automação pode ser entendida como uma "operação automática de bens" ou um processo que se torna mais automático porque substitui o trabalho físico e mental pela utilização de máquinas na produção de bens (Hitomi, 1994, p. 122).

O processo de automação não está restrito às atividades produtivas. De maneira geral, podem-se apontar três formas de automação:

a) Fluxo de produção automático em indústrias de manufatura;

b) Controle automático de produção contínua em indústrias de processo; e

c) Aumento na eficiência em negócios por computadores.

A automação mecânica e a automação de processo são direcionadas para os processos de produção diretos, que convertem materiais brutos em produtos. Esses tipos de automação são chamados automação de fábrica. $\left(\right.$ Hitomi, 1994, p. 123) ${ }^{18}$.

\footnotetext{
${ }^{18}$ A automação comercial e bancária, por sua vez, estão direcionadas para atividades de administração e controle da produção.
} 
A introdução das tecnologias de automação no setor de máquinas refletiu em dinamismo no processo de produção e ampliou as diferenças na direção e taxa de mudança técnica dos segmentos industriais de máquinas.

Outro aspecto é que com o avanço das técnicas de produção, as diferentes tecnologias de automação se tornaram endógenas ao sistema produtivo e econômico, promovendo ganhos de produtividade não apenas para o setor gerador da inovação tecnológica. Esse caráter endógeno, por sua vez, é um das principais justificativas para saltos na taxa de crescimento econômico entre os países, inclusive aqueles de industrialização recente.

Vale notar que o surgimento e a difusão das formas de automação estão condicionados às características da organização do trabalho e à disposição para alterar a base técnica do processo produtivo, em especial nos EUA e Japão.

As primeiras formas de automação na década de 1930 assumiram característica rígida porque estavam associados ao modelo de produção fordista, que reagrupava as atividades em linhas de montagem de produtos padronizados.

Naquele período, as máquinas eram fabricadas a partir de base técnica eletromecânica, que era direcionada, especialmente, para a indústria automobilística. A base técnica eletromecânica possibilitava a produção de grandes lotes de produtos (aumento da escala), a padronização de produtos e a rapidez de processos produtivos, atributos requeridos pelo modelo fordista. Entretanto, a base técnica eletromecânica também apresentava limitações como existência de trade-offs entre o tamanho das séries (ou lotes) e restrições à fabricação de variedade de produtos com uma dada tecnologia (Bastos, $\mathrm{p}$. 192, 1999).

O desenvolvimento do setor máquinas-ferramenta estava fundamentado pelos limites da base técnica eletromecânica. Em alguns casos, havia a necessidade de utilizar máquinas com sistemas flexíveis para a produção de produtos em pequena escala, mas a base técnica não possibilitava a realização de ajustes com ganhos econômicos.

A partir da década de 1950, as alterações no padrão de consumo das economias capitalistas determinaram a redução do ciclo de vida e a produção de uma variedade de produtos. Até então, essas características somente 
seriam viáveis para as empresas de pequeno porte, que apresentavam a produção intensiva em trabalho e a fabricação de pequenos lotes.

A máquina-ferramenta de comando numérico foi o primeiro protótipo de máquina que se adequava aos requerimentos de produção flexível.

As empresas de máquinas-ferramenta de pequeno porte reuniam as condições para promover alterações no processo de produção. Em grande medida, a especialização dos conhecimentos dessas empresas possibilitou a ampliação de competências para ajustar os conhecimentos às suas necessidades produtivas.

O CNC foi inventado em 1952, no Massachusetts Institute of Technology, e consistia de uma máquina dedicada à fabricação de diferentes partes, a partir da substituição de fitas de controle numérico ou informação (Hitomi, 1994, p. 123).

Em 1958, a empresa americana Kearney \& Trecker introduziu o Sistema de produção flexível (Flexible manufacturing systems - FMS). Esse sistema também denominado CMS ('computerized manufacturing systems') consistia em centro de torneamento, transportadores, veículos guiados automaticamente (automated guided vehicles - AGVs), armazéns automatizados e robôs ligados com o uso de computadores (Hitomi, 1994, p, 123).

A utilização de uma máquina mecânica (pouco elétrica) com um dispositivo de controle (micro) eletrônico acoplado mudou as condições para a transferência de conhecimentos, de informações e habilidades (Tauille, 1993, p. 201).

A partir da década de 1970, a indústria de bens de capital passou por uma nova reconfiguração mundial, com a inserção do Japão como importante produtor de máquinas, em detrimento da queda da liderança norte-americana.

A utilização da microeletrônica aumentou a velocidade de processamento das informações e reduziu os custos por informação processada. Como resultado, as empresas apresentavam mais possibilidades para o desenvolvimento de produtos (Tauille, 1993, p. 201).

Em 1979, a empresa Kearney \& Trecker registrou a marca com o nome FMS (Flexible manufacturing systems) em que o fluxo de materiais e o fluxo de informações são integrados em tempo real (Hitomi, 1994, p. 123). 
A menor unidade de automação flexível é uma célula de produção flexível (flexible machining cell - FMC), que consiste de um centro de usinagem ou centro de torneamento e um robô. Essa unidade de produção é especialmente adequada para empresas de pequeno e médio porte, do ponto de vista do alto custo-eficiência (Hitomi, 1994, p. 123).

Outra tecnologia que apresentou papel significativo para 0 desenvolvimento da indústria de máquinas é o Sistema de Manufatura Computadorizado (CIM), cunhado em 1973 por Harrington.

O sistema computadorizado tem por objetivo assegurar a redução do lead time, a adaptação flexível de uma grande variedade e a produção de pequenos lotes, através do processamento computadorizado de processos inteiros desde o pedido até o embarque (Hitomi, 1994).

O CIM pode ser compreendido como uma estratégia de adaptação ao mercado porque integra diferentes funções e sistemas, através de uma rede de informação usando computadores que mantém a autonomia (sincretismo) e a sinergia entre as áreas (Hitomi, 1994). O sistema consiste, basicamente, na integração entre três funções - produção, vendas e tecnologias - que são executadas a partir de três sistemas (quadro 3.1): Computer-aid manufacturing (CAM); Computer-aid design (CAD); Computer-aid planning (CAP).

\begin{tabular}{|c|c|c|c|}
\hline \multirow[b]{2}{*}{ Características } & \multicolumn{3}{|c|}{ Tecnologias CIM } \\
\hline & $\begin{array}{c}\text { CAM } \\
\text { (Fluxo automático de } \\
\text { materiais) }\end{array}$ & $\begin{array}{c}\text { CAD } \\
\text { (Fluxo automático de } \\
\text { informações tecnológicas) }\end{array}$ & $\begin{array}{c}\text { CAP }^{19} \\
\text { (Fluxo automático de } \\
\text { informações } \\
\text { administrativas) }\end{array}$ \\
\hline Áreas envolvidas & $\begin{array}{l}\text { - Produção; } \\
\text { - Controle de qualidade; } \\
\text { - Controle de processos; } \\
\text { - Controle de custos; } \\
\text { - Vendas/distribuição }\end{array}$ & $\begin{array}{l}\text { - Pesquisa e } \\
\text { desenvolvimento; } \\
\text { - Projeto de produto; } \\
\text { - Projeto de processo; } \\
\text { - Projeto de layout }\end{array}$ & $\begin{array}{l}\text { - Planejamento de venda; } \\
\text { - Planejamento da } \\
\text { produção; } \\
\text { - Agendamento da } \\
\text { operação. }\end{array}$ \\
\hline $\begin{array}{l}\text { Objetivos } \\
\text { principais }\end{array}$ & $\begin{array}{l}\text { - Produção multi produtos } \\
\text { em pequenos lotes; } \\
\text { - Redução dos custos com } \\
\text { trabalho direto. }\end{array}$ & $\begin{array}{l}\text { - Rapidez do projeto e } \\
\text { elaboração, } \\
\text { - Eficiência no } \\
\text { desenvolvimento de } \\
\text { produtos. } \\
\text { - Redução nos custos de } \\
\text { design. }\end{array}$ & - Entrega Just-in-time. \\
\hline
\end{tabular}

Fonte: Hitomi, 1994, p. 124 e 126-7.

Quadro 3.1 - Tecnologias e características do Sistema de Manufatura Computadorizado

No período anterior, as formas de automação contribuíram, principalmente, para a especialização dos segmentos fabricantes de máquinas.

\footnotetext{
${ }^{19} \mathrm{O}$ fluxo de informações administrativas (CAP) não é abordado no trabalho.
} 
A partir dos anos 70, o ritmo das mudanças em produtos tornou-se maior do que a capacidade de resposta dos fabricantes de máquinas, justificando 0 acesso a novas fontes de conhecimentos no desenvolvimento das máquinas.

A automação da base técnica repercutiu em modificações nas características físicas dos produtos e nos conhecimentos e habilidades acumuladas em produtos e no processo de produção.

De maneira geral, as novas tecnologias mudaram os requisitos em termos de custo de produção, nível de escala, utilização de insumos e de investimentos demandados para o desenvolvimento do setor de máquinas.

O desenvolvimento e crescimento da indústria microeletrônica possibilitou a incorporação de microprocessadores à estrutura física dos equipamentos (Coriat, 1988, 1989 apud Bastos, 1999, p. 192), contribuindo para o processo de mudança técnica da indústria de bens de capital.

O principal objetivo das empresas era a redução do custo unitário de capital, através da "intensificação da utilização de equipamentos" (Kaplinsky, 1984, p. 74-75 apud Bastos, 1999, p. 202).

Mas as novas tecnologias também incorporaram flexibilidade aos equipamentos, tornando a produção em pequenos lotes economicamente eficiente. Além disso, a integração das novas tecnologias possibilitou a gestão da circulação de matérias-primas e insumos (Bastos, 1999).

Em grande medida, as novas técnicas contribuíam para que fossem ampliados os limites produtivos determinados pela base técnica eletromecânica (Bastos, 1999).

A transição da base técnica eletromecânica para a microeletrônica trouxe implicações para as economias industriais por conta da criação de programas que permitiam a definição de tarefas executadas nas máquinas, 0 controle e a integração das funções das máquinas-ferramenta.

Com essas transformações internas ao sistema de produção, as empresas puderam ampliar a flexibilidade do processo produtivo e a variedade de produtos; e integrar diferentes etapas do processo de produção e organizacional (Bastos, 1999, p. 201).

A incorporação da microeletrônica e informática às máquinas também repercutiu em mudanças em termos de produtividade, qualidade e escopo no processo de fabricação (Bastos, 1999, p. 197). Contudo, essas alterações 
tinham como pré-condição o acúmulo de competências e de conhecimentos obtidos na produção de máquinas.

Como as condições para o desenvolvimento e melhoramento das máquinas são muito distintas entre os grupos de países, a automação de segmentos industriais assumiu características diferentes.

O Japão, por exemplo, contribuiu para um novo padrão de desenvolvimento tecnológico no ramo de máquinas-ferramenta a partir de meados da década de 60 , ocupando a posição da indústria de máquinas dos EUA.

As tecnologias de controle numérico apresentaram uma ruptura do padrão de especialização, relativamente ao setor de máquinas-ferramenta dos EUA, por conta da adoção de 'open-loop control systems' por empresas japonesas (Mazzoleni, 1997, p. 406), indicando que as estratégias de automação podem tomar diferentes caminhos entre os países.

Considerando a discussão sobre o desenvolvimento do setor de máquinas-ferramenta entre os países, destaca-se que a mudança técnica envolvia não apenas alterações na base de conhecimentos em mecânica como ocorreu na indústria de bens de capital no século XIX. A base de conhecimentos desse segmento se tornou mais dispersa e os limites das trajetórias tecnológicas tornaram-se mais tênues.

Com a incorporação de novas tecnologias, algumas empresas de bens de capital com produção de máquinas sob encomenda se distanciaram do contexto de convergência tecnológica em direção a produtos cada vez mais específicos.

Alguns fabricantes de máquinas seriadas, por sua vez, mantêm seu dinamismo sob uma mesma base técnica (mecânica), direcionando seus esforços para outros critérios definidores de competitividade como preço e flexibilidade para adaptar as máquinas às necessidades do mercado.

A inserção da microeletrônica é importante para o dinamismo industrial, mas não é o principal determinante do desenvolvimento tecnológico das empresas.

No ramo de máquinas-ferramenta, o desenvolvimento e o desempenho industrial das empresas são influenciados pela escolha entre tecnologias pervasivas, provenientes de diferentes áreas de conhecimento. A partir de 
meados do século $X X$, a sinergia entre conhecimentos da área mecânica, microeletrônica e física promoveu não apenas os ganhos de escala e escopo na produção de máquinas.

Com base na discussão realizada até aqui, é possível identificar algumas trajetórias tecnológicas relevantes para o desenvolvimento do setor de máquinas-ferramenta (quadro 3.2).

\begin{tabular}{|l|l|}
\hline \multicolumn{1}{|c|}{ Período } & \multicolumn{1}{c|}{ Trajetórias } \\
\hline $\begin{array}{l}\text { Início do } \\
\text { século XIX }\end{array}$ & $\begin{array}{l}\text { - Base de conhecimentos em mecânica; } \\
\text { - Elevada pervasividade de conhecimentos; } \\
\text { - Especialização de conhecimentos; }\end{array}$ \\
\hline $\begin{array}{l}\text { A partir de } \\
\text { meados do } \\
\text { século XIX }\end{array}$ & $\begin{array}{l}\text { - Base de conhecimentos em mecânica; } \\
\text { - Surgimento da microeletrônica; }\end{array}$ \\
\hline $\begin{array}{l}\text { A purgimento de novos materiais; } \\
\text { século XX }\end{array}$ & $\begin{array}{l}\text { - Base de conhecimentos em mecânica, microeletrônica; } \\
\text { - Surgimento de novos materiais utilizados na produção de máquinas; }\end{array}$ \\
\hline
\end{tabular}

Fonte: Elaboração própria, com base na revisão teórica da tese.

Quadro 3.2 - Trajetórias tecnológicas importantes para a indústria de máquinasferramenta mundial

As trajetórias tecnológicas promoveram transformações no desenvolvimento técnico do setor de máquinas e influenciaram as características do regime tecnológico e do processo de criação e difusão de tecnologias dos países com atuação no setor. Esse tema será discutido na próxima seção. 


\subsection{Padrão setorial e regime tecnológico na indústria de bens de capital}

O desenvolvimento da indústria de bens de capital pode ser explicado a partir do pressuposto de que há um padrão para o desenvolvimento de atividades tecnológicas que é determinado setorialmente.

De acordo com a Tipologia de Pavitt (1984), a indústria de máquinas pertence à categoria 'fornecedor especializado', que abrange os ramos de engenharia mecânica e instrumentos de precisão e apresenta as características destacadas no quadro 3.3.

\begin{tabular}{|c|c|c|}
\hline \multicolumn{2}{|c|}{ Características principais da categoria } & $\begin{array}{c}\text { Categoria de } \\
\text { Fornecedores especializados }\end{array}$ \\
\hline \multicolumn{2}{|l|}{ Atividades nucleares típicas } & Maquinaria; instrumentos de precisão. \\
\hline \multirow{3}{*}{$\begin{array}{l}\text { Fatores determinantes das } \\
\text { atividades tecnológicas }\end{array}$} & Fontes de tecnologia & Projeto e desenvolvimento pelos usuários \\
\hline & Tipos de usuários & Sensível ao desempenho \\
\hline & $\begin{array}{l}\text { Mecanismos } \\
\text { de apropriação }\end{array}$ & $\begin{array}{l}\text { Know-how de projeto; conhecimento dos usuários; } \\
\text { patentes }\end{array}$ \\
\hline \multicolumn{2}{|l|}{ Trajetórias tecnológicas } & Projeto de produto \\
\hline \multirow{4}{*}{$\begin{array}{l}\text { Características } \\
\text { mensuradas }\end{array}$} & Fontes de tecnologia & Interna; Clientes \\
\hline & $\begin{array}{l}\text { Inovação relativamente } \\
\text { predominante }\end{array}$ & Produto \\
\hline & $\begin{array}{l}\text { Tamanho relativo das } \\
\text { firmas inovadoras }\end{array}$ & Pequeno \\
\hline & $\begin{array}{l}\text { Intensidade e direção da } \\
\text { diversificação tecnológica }\end{array}$ & Baixa, concêntrica \\
\hline
\end{tabular}

Fonte: Adaptado de Pavitt (1984).

Quadro 3.3 - Características gerais das atividades inovativas para a categoria de fornecedores especializados

A categoria de fornecedores especializados é formada por empresas de pequeno e médio porte, que apresentam trajetórias tecnológicas baseadas em projeto de produto. O projeto dos produtos incorpora a maior parte das inovações desenvolvidas no ambiente interno das empresas. Além disso, os conhecimentos embutidos nesses projetos apresentam caráter incremental.

As principais fontes de inovação dos fornecedores especializados são a equipe de desenvolvimento e engenharia interna das empresas e os usuários dos produtos fabricados por essas empresas. 
As áreas de engenharia das empresas de máquinas desenvolvem importante simbiose com empresas das categorias intensivas em produção e baseadas em ciência. A interação estabelecida com os usuários das máquinas, que participam nas etapas de projeto e desenvolvimento de produtos, por sua vez, contribui para a competitividade e o dinamismo industrial dos fornecedores especializados.

Como resultado da simbiose e das interações usuário-produtor ${ }^{20}$, as empresas com produção de máquinas acumulam competências que viabilizam a produção de grande parte de suas próprias tecnologias de processo (Pavitt, 1984).

No século $X X$, esse padrão de criação de tecnologias do setor estava apoiado por conhecimentos da área mecânica, o que resultou em dois conjuntos de transformações:

a) melhoria na qualidade dos metais, das fontes de energia e a precisão de corte e usinagem.

b) habilidades em projeto e técnicas em comum no corte e moldes de metais, que eram usados na fabricação de diferentes produtos (Pavitt, 1984).

Esses aspectos possibilitaram o desenvolvimento de competências tecnológicas voltadas à realização de tarefas mais complexas e à obtenção de economias de escala. Ao longo do tempo, o caráter pervasivo em um número de tecnologias determinou a desintegração vertical de firmas especializadas no projeto e produção de máquinas para diferentes usos (Patel \& Pavitt, 1984).

Por outro lado, as empresas de máquinas tendem a apresentar baixa intensidade de estratégias visando à diversificação de produtos, e a direção dessa diversificação tende a ser mais concêntrica (Pavitt, 1994).

A diversificação concêntrica do setor de máquinas pode ser atribuída a presença de empresas de pequeno porte e a especialização da base de conhecimentos internos.

Outra justificativa para essa característica é a baixa velocidade de mudança do ciclo de vida de produtos, que resulta em menos pressões visando à diversificação (relativamente aos setores baseados em ciência) nos

\footnotetext{
${ }^{20}$ A tese considera as interações usuário-produtor uma das principais fontes de desenvolvimento tecnológico. Entretanto optou-se por não aprofundar a discussão teórica sobre esse fenômeno. Para informações mais detalhada sobre a contribuição das relações usuário-produtor para o processo inovativo, consultar Lundvall (1988; 1982).
} 
mercados em que as empresas atuam. Além disso, a baixa intensidade da diversificação de produtos pode ser atribuída ao fato de que enquanto empresas dos setores baseados em ciência diversificaram-se a partir dos avanços da ciência que são acumulados ao longo do tempo, os fornecedores especializados de máquinas dependem mais de seus consumidores para obter e acumular informações e habilidades relacionadas ao desempenho de seus produtos (Pavitt, 1984).

Apesar de apresentar baixa intensidade de diversificação de produtos, 0 setor de máquinas apresenta elevada integração dos conhecimentos tecnológicos (internos às empresas) com conhecimentos provenientes de áreas da ciência como engenharia de materiais, engenharia de produção e eletrônica, entre outras.

A literatura sobre o desenvolvimento tecnológico da indústria de máquinas destaca que os conhecimentos incorporados às máquinas surgiram, principalmente, da exploração e de descobertas científicas e usos em comum em outras áreas e ramos industriais (Rosenberg, 1963; 1969). Por outro lado, os conhecimentos da categoria fornecedores especializados também são utilizados para o desenvolvimento e melhorias em produtos para outros ramos industriais (Pavitt, 1984).

Um aspecto não apresentado na tipologia de Pavitt (1984) é que o regime tecnológico entre os segmentos de máquinas fornecerá diferentes possibilidades para criação e incorporação de conhecimentos e a mudança técnica daqueles setores.

De maneira geral, cada segmento da indústria de máquinas apresentará uma combinação diferente de conhecimentos internos (na forma de tecnologias e competências), de condições de oportunidade e condições de apropriabilidade ao longo da cadeia.

No setor de máquinas-ferramenta, por exemplo, o conhecimento interno pode abranger tecnologias pervasivas que influenciam as oportunidades sobre novos produtos. As tecnologias com usos em comum em várias etapas possibilitaram o desenvolvimento de máquinas para vários ramos industriais. À medida que as especificações daquelas máquinas eram melhoradas, as condições de oportunidade para o desenvolvimento e difusão de novos produtos foram ampliadas. 
No setor de máquinas para calçados, por sua vez, as tecnologias são menos pervasivas e estão restritas ao processo de fabricação de calçados. Desse modo, as condições de oportunidade tendem a ser relativamente menores.

O regime tecnológico da indústria de máquinas pode apresentar algumas alterações em virtude das condições do ambiente em que os setores estão inseridos.

Em países como EUA, Japão e Alemanha, um dos fatores que contribuíram para o desenvolvimento tecnológico das máquinas é que os conhecimentos internos às empresas incorporavam competências acumuladas e informações provenientes de outras áreas da ciência ou de um novo modelo organizacional. Nesse cenário, os conhecimentos contribuíram para a mudança técnica e os ganhos de produtividade ao nível da firma e dos setores de máquinas e representam as trajetórias tecnológicas da indústria de máquinas nas últimas décadas.

A tese parte do pressuposto de que a atuação das empresas de máquinas e dos demais atores do setor no ambiente em que elas estão inseridas é diferente em cada país e essas características conduzem a diferenças no desenvolvimento tecnológico do setor. Considera-se que uma das fontes de diferenças no desenvolvimento tecnológico do setor de máquinas é a percepção das empresas de máquinas em relação ao potencial das trajetórias tecnológicas.

O próximo capítulo apresenta as definições sobre os produtos incluídos no setor de máquinas e apresenta um breve panorama sobre a dinâmica industrial do setor de máquinas-ferramenta. Posteriormente, o capítulo retoma a discussão sobre regime tecnológico e Sistema Setorial de Inovação de máquinas-ferramenta considerando quatro países selecionados. 


\section{Capítulo 4 - 0 setor de máquinas-ferramenta em países selecionados}

Esse capítulo apresenta um panorama sobre o desempenho do setor de máquinas-ferramenta mundial nos últimos anos.

Na primeira seção, o capítulo apresenta brevemente as características dos produtos, processos e tecnologias do setor de máquinas-ferramenta.

A segunda seção apresenta a análise de dados estatísticos sobre produção e comércio internacional de máquinas-ferramenta, destacando os resultados por categorias de produtos e países.

A terceira seção aplica a discussão sobre regime tecnológico e Sistema Setorial de Inovação ao setor de máquinas-ferramenta. Nesse ponto, o texto ressalta as principais características e fatores envolvidos no desenvolvimento do ramo de máquinas-ferramenta dos países desenvolvidos líderes na produção de máquinas.

\subsection{Produtos, processos e tecnologias do setor de máquinas-ferramenta.}

A formação do setor de máquinas-ferramenta e o seu desenvolvimento e desempenho nas economias industrializadas ao longo das décadas contribuíram de maneira significativa para o desenvolvimento de tecnologias entre os países. Ao mesmo tempo, os ramos industriais de máquinas tornaramse importante receptor e transformador de conhecimentos provenientes de outros setores e outra áreas de conhecimento científico.

A máquina-ferramenta pode ser definida de maneira simplificada como uma máquina projetada para o trabalho com metais e outros materiais, permitindo que um bloco de ferro fundido seja convertido em outros produtos (Avellar, 2008, p. 1).

A International Standard of Industrial Classification ${ }^{21}$ apresenta os segmentos da indústria de bens de capital em quatro divisões, de acordo com

\footnotetext{
21 A International Standard of Industrial Classification (ISIC) Rev. 4⿳a a é classificação de atividade econômica mais recente, revisada em 2008. Os dados de produção e valor adicionado do setor disponíveis no sítio eletrônico para consulta utilizaram a classificação ISIC na versão Rev. 3
} 
as características técnicas e processos em comum de cada ramo da indústria: Fabricação de equipamentos elétricos; Fabricação de máquinas e equipamentos não incluídos anteriormente; Fabricação de veículos automotores, reboques e semi-reboques; e Fabricação de outros equipamentos de transporte.

As quatro divisões são subdivididas em grupos. A divisão "máquinas e equipamentos não incluídos anteriormente" (ISIC 28), por exemplo, abrange os grupos "máquinas de uso geral" e "máquinas de uso específico". O grupo de máquinas de uso específico, por sua vez, abrange várias classes de produtos, incluindo o ramo de máquinas-ferramenta ou Manufacture of metal-forming machinery and machine (ISIC 2822) ${ }^{22}$.

É importante registrar que as classificações da indústria de bens de capital denotam as especificidades técnicas de produto e a heterogeneidade dos processos de produção das máquinas.

Os produtos do ramo de máquinas-ferramenta podem apresentar características distintas em relação à finalidade principal, tamanho, design, sistema de controle e processos produtivos envolvidos, entre outros fatores (Avellar, 2008, p. 2). Além disso, cada linha de produtos pode apresentar diferenças na forma de realização das tarefas (ou base produtiva).

Em relação à sua finalidade, as máquinas-ferramenta podem ser classificadas em dois grupos: máquinas de usinagem (corte) e máquinas de dar forma ${ }^{23}$.

A atividade de usinagem consiste no processo mecânico no qual a peça é uma matéria-prima que será transformada através da remoção (corte) de parte do seu material. O processo de dar forma, por sua vez, inclui, principalmente, as operações de dobrar, prensar, talhadeira e estampagem.

A usinagem inclui as tarefas de serramento, aplainamento, torneamento, fresamento (ou fresagem), furação, brochamento, trituração, entre outros, que podem ser realizados com lascas ou com criação de cavaco. O quadro 4.1 apresenta as características dos principais tipos de máquinas utilizados no processo de usinagem.

\footnotetext{
${ }^{22} \mathrm{O}$ anexo A apresenta o quadro com a descrição completa dos tipos de produtos incluídos na ISIC 2922.

${ }^{23}$ Apenas as máquinas de corte são objeto de análise da tese.
} 


\begin{tabular}{|c|c|c|}
\hline Máquinas & Descrição das características das máquinas & Tipos de máquinas \\
\hline Fresadora & $\begin{array}{l}\text { - Fresadora é uma máquina de movimento continuo, destinada à } \\
\text { usinagem de materiais. Ela remove cavacos por meio de uma } \\
\text { ferramenta de corte chamada fresa. } \\
\text { - Essas máquinas realizam de uma grande variedade de trabalhos } \\
\text { tridimensionais. O corte pode ser realizado em superfícies } \\
\text { situadas em planos paralelos, perpendiculares, ou formando } \\
\text { ângulos diversos. } \\
\text { - As fresadoras podem ser classificadas de acordo com a posição } \\
\text { do eixo-árvore em relação à superfície da mesa de coordenadas. }\end{array}$ & - Horizontal, vertical, universal e especial. \\
\hline Mandriladora & $\begin{array}{l}\text { - São máquinas especiais, que podem desempenhar as } \\
\text { operações de usinagem sem que seja preciso remover a peça } \\
\text { da máquina. } \\
\text { - Podem ser utilizadas para furação, fresagem, mandrilagem e } \\
\text { torneamento em peças complicadas e difíceis de manusear. } \\
\text { - Uma mandriladora é composta, principalmente, por árvore porta- } \\
\text { ferramentas, carro porta-árvore,montande, coluna auxiliar, mesa } \\
\text { de máquina e mandril (Moraes \& Abreu, 2006). }\end{array}$ & \\
\hline Torno & $\begin{array}{l}\text { - É uma máquina-ferramenta utilizada na usinagem ou } \\
\text { acabamento em peças. } \\
\text { - A máquina utiliza placas para fixação da peça a ser trabalhada. } \\
\text { - As placas podem ser de três castanhas, se a peça for cilíndrica, } \\
\text { ou quatro castanhas, se o perfil da peça for retangular. } \\
\text { - Os tornos podem ser classificados de acordo com os } \\
\text { componentes eletrônicos (tradicional, revólver, CNC); de acordo } \\
\text { com a geometria e tamanho da peça que será usinada } \\
\text { (horizontal ou vertical); }\end{array}$ & $\begin{array}{l}\text { - Torno mecânico: } \\
\text { - Torno CNC: máquina na qual o } \\
\text { processo de usinagem é feita por } \\
\text { Comandos Numéricos } \\
\text { Computadorizados (CNC) através de } \\
\text { coordenadas X (vertical) e Z } \\
\text { (longitudinal). Sua grande vantagem em } \\
\text { relação ao torno mecânico é o } \\
\text { acabamento e o tempo de produção. } \\
\text { - Torno revolver: torno simples com o } \\
\text { qual é possível executar processos de } \\
\text { usinagem com rapidez, em peças } \\
\text { pequenas[Ex: buchas] } \\
\text { Torno vertical: usado para trabalhar } \\
\text { com peças com um diâmetro elevado; }\end{array}$ \\
\hline Retificadora & $\begin{array}{l}\text { - Retificadoras são máquinas derivadas dos tornos mecânicos } \\
\text { - Elas realizam as tarefas de retífica (alinhamento) e polimento de } \\
\text { peças e componentes cilíndricos ou planos. }\end{array}$ & \\
\hline
\end{tabular}

Fonte: Adaptado de Material didático (versão eletrônica), Centro de Informação Metal Mecânica (CIMM).

Disponível em: http://www.cimm.com.br/portal/noticia/material didatico/3350. Atualizado em 01/outubro/12.

Quadro 4.1 - Descrição das máquinas-ferramenta de usinagem

Considerando as características gerais do processo de produção, as máquinas-ferramenta podem ser classificadas em dois grupos: máquinas seriadas ou máquinas sob encomenda.

As máquinas seriadas apresentam grande variedade de produtos com pequenas modificações dentro de uma mesma linha de máquinas. O grupo de máquinas seriadas é formado, principalmente, por modelos utilizados na usinagem de peças como tornos, retificadoras, fresadoras, entre outras.

O principal requisito para o processo produtivo dessas máquinas é a escala de produção. As empresas que desenvolvem modelos de máquinas seriadas tendem a produzir os produtos em módulos, e mantém uma parte das máquinas pré-acabadas em estoque. Nas etapas finais de produção dessas máquinas, as empresas realizam a incorporação de componentes (ferramentas e eletrônicos), de acordo com a especificação do cliente. 
As máquinas fabricadas sob encomenda apresentam pequena variedade de produtos e incorporam especificações de acordo com os pedidos dos clientes. O grupo de máquinas sob encomenda é formado, principalmente, por modelos de máquinas de usinagem (corte): centros de torneamento e fresamento, células de produção, entre outros; e por máquinas utilizadas na conformação de materiais (prensas) que incorporam tecnologias mais sofisticadas.

O principal requisito para o processo produtivo da máquina sob encomenda não é a escala de produção, mas a flexibilidade para incorporar as características ou componentes de acordo com o pedido do cliente. Um fator importante é que como os produtos finais são concebidos e projetados para atender especificidades de um cliente, frequentemente, esses modelos de máquinas não são incluídos na linha comercial de produtos da empresa. Além disso, o tempo de produção dessas máquinas tende a ser relativamente maior do que o tempo decorrido para a produção das máquinas seriadas.

O processo de produção das máquinas é viabilizado por duas categorias de atividades internas das áreas da engenharia (de produto): o projeto mecânico e o processo de fabricação.

O projeto mecânico é a fase em que os funcionários analisam informações internas e externas visando à criação de uma nova máquina ou a melhoria do produto já existente (Collins, 2006a, p. 6). Esse processo abrange desde a concepção inicial, o desenvolvimento até o serviço de campo da máquina.

Para desenvolver o projeto considerando as informações técnicas internas (econômicas e não econômicas) e os requisitos da demanda, o projetista seleciona o melhor material disponível e identifica a melhor geometria possível para cada peça (Collins, 2006a, p. 1). Entretanto, em alguns casos 0 projetista mecânico não consegue desenvolver 0 projeto que atenda às especificações de material e de geometria simultaneamente.

Os critérios de desempenho, o peso e os custos dos materiais utilizados na produção da peça podem impor algumas limitações e divergências para a utilização dos materiais e geometria propostos pelo projetista da máquina (Collins, 2006a, p. 6). 
O processo de fabricação estrito é a fase em que as peças disponíveis em estoque são trabalhadas, considerando as dimensões, formas e acabamentos especificados pelo projetista da máquina (Collins, 2006b, p. 279). Esse processo de fabricação das máquinas abrange um conjunto de etapas em comum como corte, conformação, processamento químico-físico ou a combinação dessas técnicas. Cada etapa, por sua vez, reúne um conjunto de especificidades quanto à sua forma de realização.

O quadro 4.2 descreve as categorias de processos envolvidos na fabricação de máquinas e alguns exemplos de cada processo ${ }^{24}$.

\begin{tabular}{|l|l|}
\hline \multicolumn{1}{|c|}{ Categoria de processo } & \multicolumn{1}{c|}{ Exemplos de processos } \\
\hline Fluxo de material fundido & $\begin{array}{l}\text { Fundição em: areia, casca, molde cerâmico, molde permanente; Fundição sob } \\
\text { pressão, por centrifugação, por cera perdida; Outros. }\end{array}$ \\
\hline Fusão de partes componentes & $\begin{array}{l}\text { Soldagem ao arco elétrico; a gás; por resistência elétrica; por feixe de elétrons; } \\
\text { Outros. }\end{array}$ \\
\hline $\begin{array}{l}\text { Deformação plástica de material } \\
\text { sólido dúctil }\end{array}$ & $\begin{array}{l}\text { Forjamento por martelamento; por prensagem; Laminação; Trefilação; Extrusão; } \\
\text { Dobramento; Estampagem profunda; Repuxamento; Estiramento; Outros. }\end{array}$ \\
\hline $\begin{array}{l}\text { Remoção seletiva de material por } \\
\text { ação de usinagem ou ação de } \\
\text { remoção de cavaco }\end{array}$ & $\begin{array}{l}\text { Torneamento; Faceamento; Furação; Fresagem; Broqueamento; Retificação; } \\
\text { Serramento; Outros. }\end{array}$ \\
\hline $\begin{array}{l}\text { Sinterização de partículas de pó } \\
\text { metálico }\end{array}$ & $\begin{array}{l}\text { União por difusão; Sinterização com fase líquida; Sinterização por centelha; } \\
\text { Processamento isostático a quente (HIP) }\end{array}$ \\
\hline
\end{tabular}

Fonte: Adaptado de Collins (2006b), p. 279.

Quadro 4.2 - Categoria de processos e exemplos

A remoção seletiva de material por ação de usinagem ou ação de remoção de cavaco abrange, principalmente, os processos de torneamento; faceamento; furação; fresagem (ou fresamento); broqueamento; retificação; e serramento. O quadro 4.3 apresenta uma breve descrição das características de três processos de usinagem: fresamento, retificação e torneamento.

\footnotetext{
${ }^{24} \mathrm{O}$ foco da análise empírica da tese são empresas de máquinas-ferramenta que trabalham com o processo de remoção seletiva de material por ação de usinagem ou ação de remoção de cavaco.
} 


\begin{tabular}{|c|c|}
\hline Processos & Descrição do processo \\
\hline Fresamento & $\begin{array}{l}\text { - O fresamento consiste na combinação de movimentos simultâneos da ferramenta e da peça a ser } \\
\text { usinada. } \\
\text { - A ferramenta de corte possui vários gumes e executa movimento de giro, enquanto é pressionada contra } \\
\text { a peça (que também está em movimento). }\end{array}$ \\
\hline Retificação & $\begin{array}{l}\text { - É o processo de tornar reto ou exato, corrigir e polir a superfície de peças e componentes cilíndricos ou } \\
\text { planos. } \\
\text { - O processo de retificação é executado por ferramentas chamadas de rebolos, que são ferramentas } \\
\text { fabricadas com materiais abrasivos cujos formatos podem ser cilíndricos, ovalizados, esféricos, etc. } \\
\text { - Em geral, as ferramentas são fixadas a eixos e giram em altíssima rotação. Quando elas já vem presas } \\
\text { em um eixo são chamadas de ponta montada. } \\
\text { - A peça que será trabalhada é montada num suporte, numa mesa coordenada ou num eixo, e recebe o } \\
\text { atrito do rebolo abrasivo, que vai retirando o material em quantidades muito pequenas, até chegar ao } \\
\text { ponto ou dimensão determinado pelo projeto. }\end{array}$ \\
\hline Torneamento & $\begin{array}{l}\text { - A operação de torneamento consiste no movimento de máquinas-ferramenta que operam fazendo girar a } \\
\text { peça a usinar presa em um cabeçote placa de } 3 \text { ou } 4 \text { castanhas ou fixada entre os contra-pontos de } \\
\text { centragem enquanto uma ou diversas ferramentas de corte são pressionadas em um movimento } \\
\text { regulável de avanço de encontro à superfície da peça, removendo material de acordo com as condições } \\
\text { técnicas adequadas. } \\
\text { - Trata-se da combinação de dois movimentos: rotação da peça e movimento de avanço da ferramenta. } \\
\text { Em algumas aplicações, a peça pode ser estacionária, com a ferramenta girando ao seu redor para } \\
\text { cortá-la, mas basicamente o princípio é o mesmo. }\end{array}$ \\
\hline
\end{tabular}

Fonte: Adaptado de Material didático (versão eletrônica), Centro de Informação Metal Mecânica (CIMM).

Disponível em: http://www.cimm.com.br/portal/noticia/material didatico/3350. Atualizado em 01/outubro/12.

Quadro 4.3 - Descrição de alguns processos usinagem

A escolha e a utilização de um daqueles processos na produção de máquinas-ferramenta são permeadas pela análise de fatores econômicos e não econômicos, por análises das propriedades físicas dos materiais que compõem as peças, e pelo tipo do acabamento final que pretende-se obter.

Os fatores econômicos como o custo de capital influenciam as decisões de investimento no desenvolvimento de nova máquina, na modernização ou reforma das máquinas. Os fatores não econômicos como a energia e tempo requeridos e a resistência relativa do produto, entre outros, determinam diferenças no desempenho técnico das máquinas. O quadro 4.4 apresenta os parâmetros econômicos e não econômicos associados à cada categoria de processo. 


\begin{tabular}{|c|c|c|c|c|c|}
\hline $\begin{array}{l}\text { Categoria } \\
\text { de processo }\end{array}$ & $\begin{array}{l}\text { Custos de } \\
\text { capital para } \\
\text { equipamento } \\
\text { s especiais }\end{array}$ & $\begin{array}{l}\text { Custos de } \\
\text { ferramentas } \\
\text { especiais }\end{array}$ & $\begin{array}{l}\text { Energia } \\
\text { requerida }\end{array}$ & $\begin{array}{l}\text { Tempo } \\
\text { requerido }\end{array}$ & $\begin{array}{c}\text { Resistência } \\
\text { relativa do } \\
\text { produto }\end{array}$ \\
\hline Fluxo de material fundido & $\begin{array}{l}\text { Relativamente } \\
\text { elevado }\end{array}$ & $\begin{array}{l}\text { Relativamente } \\
\text { baixo }\end{array}$ & $\begin{array}{c}\text { Relativamente } \\
\text { baixa }\end{array}$ & $\begin{array}{l}\text { Relativamente } \\
\text { baixo }\end{array}$ & $\begin{array}{l}\text { Geralmente } \\
\text { mais pobre }\end{array}$ \\
\hline $\begin{array}{l}\text { Fusão de partes } \\
\text { componentes }\end{array}$ & $\begin{array}{l}\text { Relativamente } \\
\text { baixo }\end{array}$ & $\begin{array}{l}\text { Relativamente } \\
\text { baixo }\end{array}$ & Moderada & Moderado & Moderada \\
\hline $\begin{array}{l}\text { Deformação plástica de } \\
\text { material sólido dúctil }\end{array}$ & $\begin{array}{l}\text { Relativamente } \\
\text { elevado }\end{array}$ & $\begin{array}{l}\text { Relativamente } \\
\text { elevado }\end{array}$ & $\begin{array}{c}\text { Relativamente } \\
\text { elevada }\end{array}$ & $\begin{array}{l}\text { Relativamente } \\
\text { baixo }\end{array}$ & $\begin{array}{l}\text { Geralmente } \\
\text { melhor }\end{array}$ \\
\hline $\begin{array}{l}\text { Remoção seletiva de } \\
\text { material por ação de } \\
\text { usinagem ou ação de } \\
\text { remoção de cavaco }\end{array}$ & $\begin{array}{l}\text { Relativamente } \\
\text { baixo }\end{array}$ & $\begin{array}{l}\text { Relativamente } \\
\text { baixo }\end{array}$ & Moderada & $\begin{array}{c}\text { Relativamente } \\
\text { elevado }\end{array}$ & $\begin{array}{l}\text { Segundo } \\
\text { melhor }\end{array}$ \\
\hline $\begin{array}{l}\text { Sinterização de partículas } \\
\text { de pó metálico }\end{array}$ & Moderado & $\begin{array}{l}\text { Relativamente } \\
\text { elevado }\end{array}$ & Moderada & Moderado & n.d. \\
\hline
\end{tabular}

Fonte: Adaptado de Collins, 2006b, p. 279.

Quadro 4.4 - Categoria de processos e a importância de parâmetros selecionados

De acordo com os dados do quadro acima, verifica-se que as quatro primeiras categorias de processo apresentam um trade-off entre os fatores energia e tempo requeridos versus os fatores econômicos como o custo de equipamentos especiais.

A escala de produção de máquinas seriadas e a flexibilidade na produção de máquinas sob encomenda também são fatores importantes nas decisões de produção das máquinas.

As características dos materiais utilizados na construção das máquinas, como maleabilidade, resistência, condutibilidade, entre outros, também têm implicações para a análise dos fatores econômicos e não econômicos de cada categoria de processo de máquinas.

O quadro 4.5 apresenta algumas características consideradas na decisão de utilizar um material (em detrimento de outros) e destaca os índices de avaliação para cada característica. 


\begin{tabular}{|l|l|l|}
\hline \multicolumn{1}{|c|}{$\begin{array}{c}\text { Características requeridas do } \\
\text { material adequado }\end{array}$} & \multicolumn{1}{c|}{$\begin{array}{c}\text { Índice de avaliação de } \\
\text { desempenho }\end{array}$} \\
\hline 1 & Razão resistência/volume & Limite de escoamento ou de resistência \\
\hline 2 & Razão resistência/peso & Limite de escoamento ou de resistência/densidade \\
\hline 3 & Resistência ao calor & Perda de resistência/grau de temperatura \\
\hline 4 & Resistência à fluência & Taxa de fluência na temperatura de operação \\
\hline 5 & Expansão térmica & Deformação/grau de variação de temperatura \\
\hline 6 & Rigidez & Módulo de elasticidade \\
\hline 7 & Ductilidade & Alongamento percentual em 2 polegadas \\
\hline 8 & Resiliência & Energia/unidade de volume no escoamento \\
\hline 9 & Tenacidade & Energia/umidade de volume na ruptura \\
\hline 10 & Resistência ao desgaste & Perda dimensional na condição de operação; também dureza \\
\hline 11 & Resistência à corrosão & Perda dimensional no meio da operação \\
\hline 12 & Susceptibilidade a danos por radiação & Mudança na resistência ou ductilidade no meio operacional \\
\hline 13 & Manufaturabilidade & Adequação para processo específico \\
\hline 14 & Custo & Custo/unidade de peso; também usinabilidade \\
\hline 15 & Disponibilidade & Tempo e esforço para obtenção. \\
\hline Fonte: Collins, 2006 p. 114 & \\
\hline
\end{tabular}

Fonte: Collins, 2006b, p. 114.

Quadro 4.5 - Requisitos dos materiais para aplicação e índices de avaliação de desempenho

As características dos materiais que compõem as peças a serem trabalhadas influenciarão diretamente na realização das tarefas programadas para cada máquina.

As máquinas precisam estar preparadas para trabalhar com as diferenças das características físicas dos materiais e manter a produtividade, precisão e qualidade na fabricação das peças. Para viabilizar essa situação, as empresas de máquinas apresentam algumas alterações em parâmetros como velocidade de corte, profundidade da entrada da ferramenta de corte na peça, quantidade de formação de cavaco e tempo para a produção da peça final.

O desenvolvimento e as melhorias de alguns dos parâmetros do processo de produção, por sua vez, são realizados ao longo do processo produtivo, na forma de tentativa-erro, e estão apoiados em conhecimentos e competências empíricos (do ambiente da produção).

A combinação de tecnologias e conhecimentos visando à execução de tarefas de acordo com as características dos materiais, e que possibilitem

\footnotetext{
${ }^{25}$ Usinabilidade pode ser entendida como a facilidade com que o material pode ser cortado, torneado, fresado ou furado sem acarretar prejuízo de suas propriedades mecânicas (Material didático, Centro de Informação Metal Mecânica, 2012).
} 
ganhos de produtividade e escala e a qualidade dos produtos, são fatores importantes para o desempenho técnico das máquinas.

As mudanças das características dos materiais (ou o surgimento de novos materiais) e o desenvolvimento ou melhorias dos parâmetros para lidar com aquelas características influenciam os ganhos de produtividade e escala das empresas e o desempenho da estrutura industrial recente do setor de máquinas-ferramenta. Entretanto, o desenvolvimento da ciência dos materiais não promoveu rupturas da base de conhecimentos técnico das máquinasferramenta, que estão apoiados em conhecimentos da área de engenharia mecânica.

O desenvolvimento e as melhorias técnicas das máquinas-ferramenta estão vinculados à identificação de diferentes trajetórias tecnológicas, ao aprendizado e à apropriação dos conhecimentos considerando as condições de cada empresa.

O setor mantém forte interdependência entre os três elementos do sistema de máquinas-ferramenta (estruturais, de transmissão e de controle). As alterações realizadas em um desses elementos podem provocar desequilíbrios na execução das tarefas da máquina-ferramenta, e implicam a necessidade de realizar melhorias no sistema.

A inserção da tecnologia da informação no setor de máquinas contribuiu para o funcionamento e o dinamismo do sistema de máquinas ao integrar diferentes tarefas e possibilitar a realização dessas tarefas de maneira mais eficiente.

Os conhecimentos técnicos utilizados no projeto e desenvolvimento das máquinas são provenientes de diferentes áreas de conhecimento. E essa alta pervasividade pode contribuir de maneira significativa para o desempenho e a integração entre esses elementos do sistema de máquinas-ferramenta.

As ferramentas incorporadas às máquinas, por exemplo, possibilitam pequenos ajustes ou alterações radicais dos parâmetros de produção e podem ajudar na realização das tarefas em uma peça (Collins, 2006a)

Os componentes eletrônicos como comando numérico computadorizado (CNC) compõem os elementos de controle das máquinas e têm a função de ajustar os elementos estruturais da máquina e controlar o seu funcionamento. Além disso, os componentes eletrônicos viabilizam a precisão e melhor 
programação e execução das tarefas desde o projeto da máquina até a etapa final da produção (Collins, 2006a).

Nesse cenário, os fornecedores do setor de máquinas-ferramenta influenciam duplamente no desenvolvimento das máquinas: de um lado, com materiais usados na produção das peças; e de outro lado, com ferramentas desenvolvidas para as máquinas e componentes eletrônicos que podem ser acoplados às máquinas.

A utilização de comandos numéricos representa uma das trajetórias do desenvolvimento técnico recente do setor de máquinas-ferramenta. Isso porque a automação da base técnica das máquinas-ferramenta possibilitou a ampliação dos limites produtivos do setor (Bastos, 1999) e mudou os requisitos de produção em termos de escala e os critérios relativos aos custos de produção das máquinas.

Com base na discussão realizada até aqui, é possível destacar que a difusão e a consolidação das trajetórias entre as empresas de máquinasferramenta dependem da criação e difusão de informações sobre processos e produtos, e que esse processo se torne endógeno ao sistema econômico.

À medida que os conhecimentos técnicos são desenvolvidos ou melhorados no ambiente interno das empresas e entre os segmentos industriais de máquinas, é importante que as empresas se apropriem de tais conhecimentos e criem competências e habilidades próprias em suas áreas de atuação. A estrutura científica, tecnológica e produtiva dos países também apresenta papel importante nesse processo, por viabilizar a sinergia entre diferentes áreas de conhecimentos e a absorção das informações entre as empresas.

Esses fatores são responsáveis pela heterogeneidade da estrutura produtiva da indústria de máquinas-ferramenta e repercutiram no desempenho econômico e industrial entre os segmentos fabricantes de máquinas-ferramenta através dos países. 


\subsection{Produção e comércio mundial do setor de máquinas-ferramenta}

Nos últimos anos, o ramo de máquinas-ferramenta tem apresentado alterações em sua estrutura produtiva e no desempenho industrial e econômico no mercado mundial.

O número de empresas e do total de emprego entre segmentos fabricantes de máquinas tem apresentado declínio do. $\mathrm{O}$ desempenho industrial e econômico, por sua vez, tem sido influenciado pela inserção de alguns países na produção e comércio mundial do setor. O gráfico 4.1 apresenta dados sobre o número de empresas do grupo de máquinas de uso especial e do segmento de máquinas-ferramenta no período de 2005 a 2009.

Gráfico 4.1 - Número de empresas do grupo de máquinas especiais e do setor de máquinasferramenta no mundo, 2005-2009.

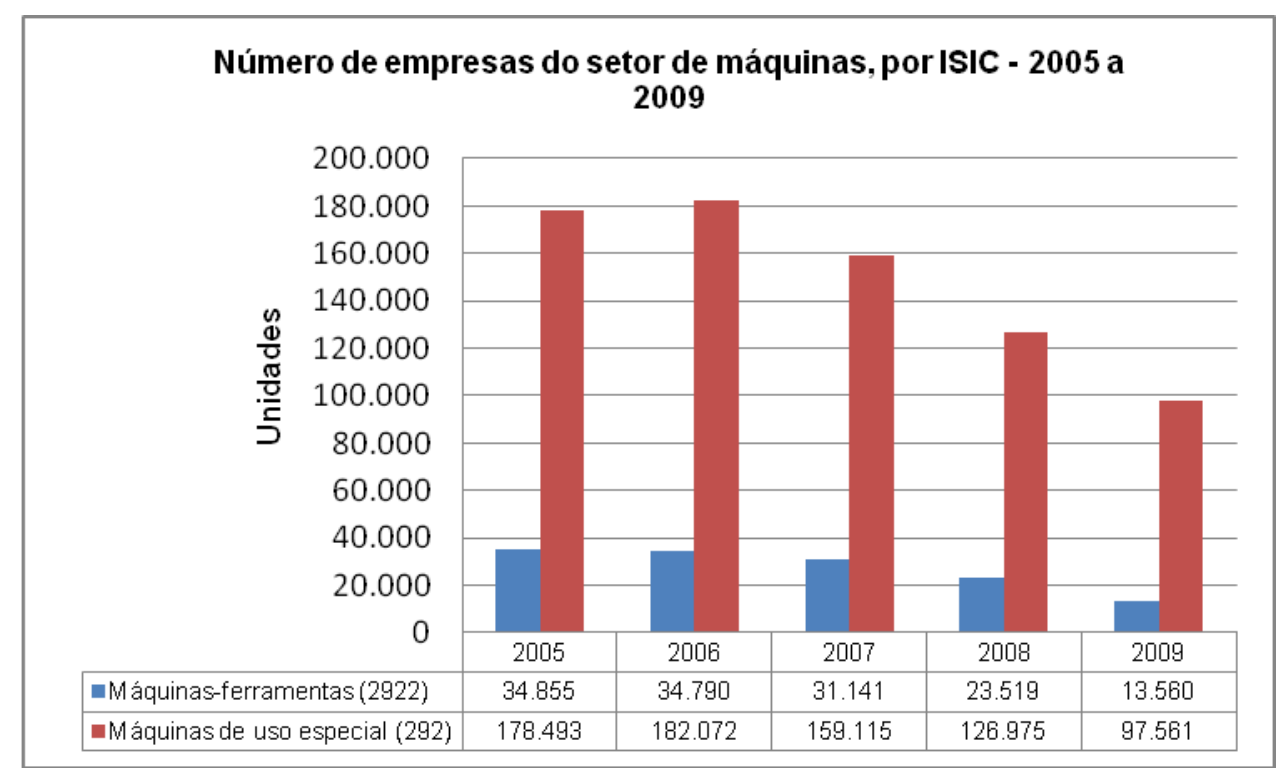

Fonte: Elaboração própria, com base nos dados da INDSTAT4 (Industrial Statistics Database), 2012. Statistics Division, United Nations Industrial Development Organization (UNIDO) ${ }^{26}$

Disponível em: <http://data.un.org/Data.aspx?d=UNIDO\&f=tableCode\%3a01> > Acesso em: 04/out/12.

O setor de máquinas especiais e o ramo de máquinas-ferramenta têm apresentado redução do número de estabelecimentos desde o ano de 2006. Particularmente no período 2008-2009, ambos os setores apresentaram fechamento, respectivamente, de $23 \%$ e $42 \%$ do total de estabelecimentos com produção de máquinas.

\footnotetext{
26 INDSTAT4-Rev. 3 contém dados de series de tempo sobre cinco intens que cobre o período de 2005 a 2009. Os dados são agregados a 3 e a 4 dígitos da ISIC (Revisão 3) da indústria de manufatura, que abrange 151 categorias de produtos (UNIDO, 2012 - tradução).
} 
Outro fator importante é que o ramo de máquinas-ferramenta perdeu a participação no total de empresas com produção de máquinas especiais, passando de 19,57\% em 2007 para 13, 9\% em 2009.As estatísticas sobre número de funcionários empregados pelo setor (gráfico 4.2) corroboram a situação verificada em relação ao número de empresas daqueles ramos de máquinas.

Gráfico 4.2 - Número de trabalhadores empregados no grupo de máquinas especiais e no setor de máquinas-ferramenta no mundo, 2005-2009.

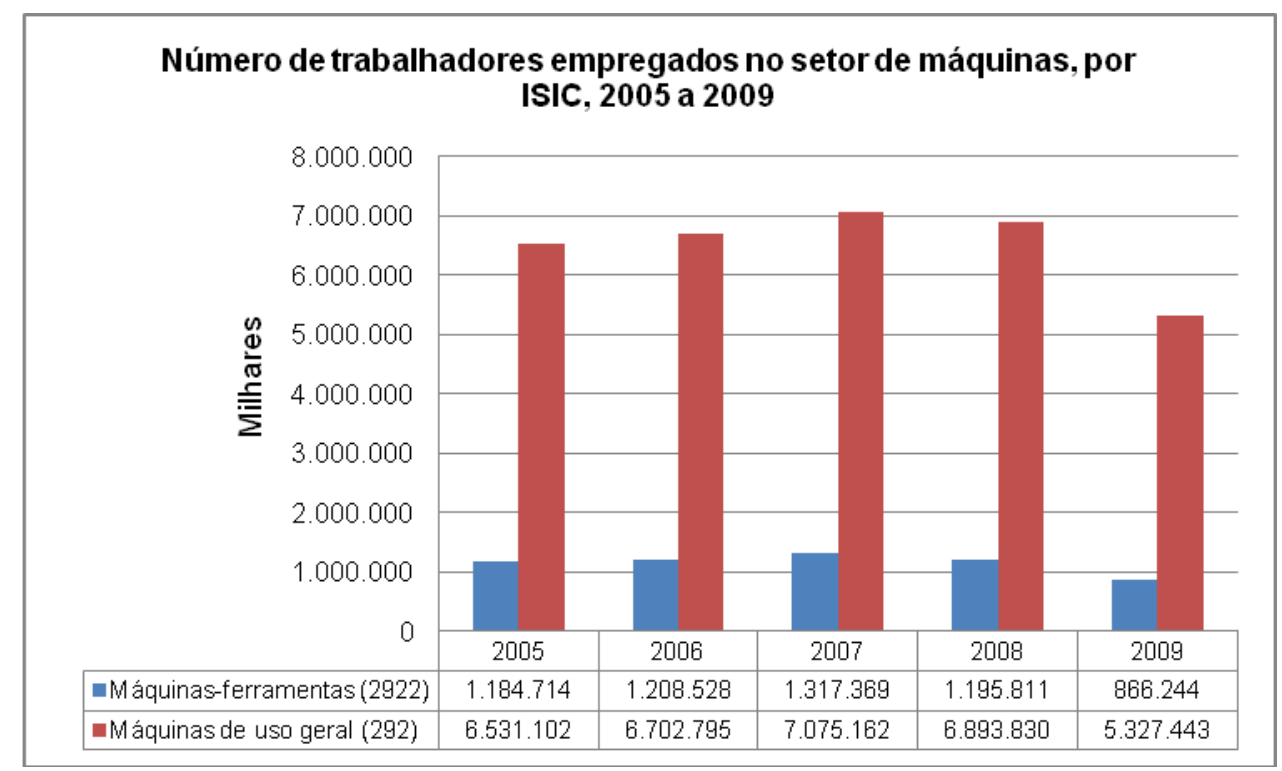

Fonte: Elaboração própria, com base nos dados de Statistics Division, United Nations Industrial Development Organization (UNIDO). Disponível em: http://data.un.org/Data.aspx?d=UNIDO\&f=tableCode\%3a04. Acesso em 04/out/12.

Até o ano de 2007, o grupo de máquinas especiais e o ramo de máquinas-ferramenta apresentaram crescimento do número de funcionários contratados.

A partir de 2008, ambos os setores apresentaram demissão de funcionários, mas o setor de máquinas-ferramenta foi mais atingido pelo processo de demissão, como se verifica pela queda de $27 \%$ do volume de emprego, relativamente à redução de $22 \%$ do setor de máquinas especiais.

A queda do número de empresas e a redução do emprego do setor de máquinas-ferramenta estão atreladas à queda da produção mundial de máquinas sofrida no ano de 2008. O gráfico 4.3 apresenta dados sobre a produção mundial deste setor. 
Gráfico 4.3 - Produção mundial do setor de máquinas e do ramo de máquinas-ferramenta, 2005-2009.

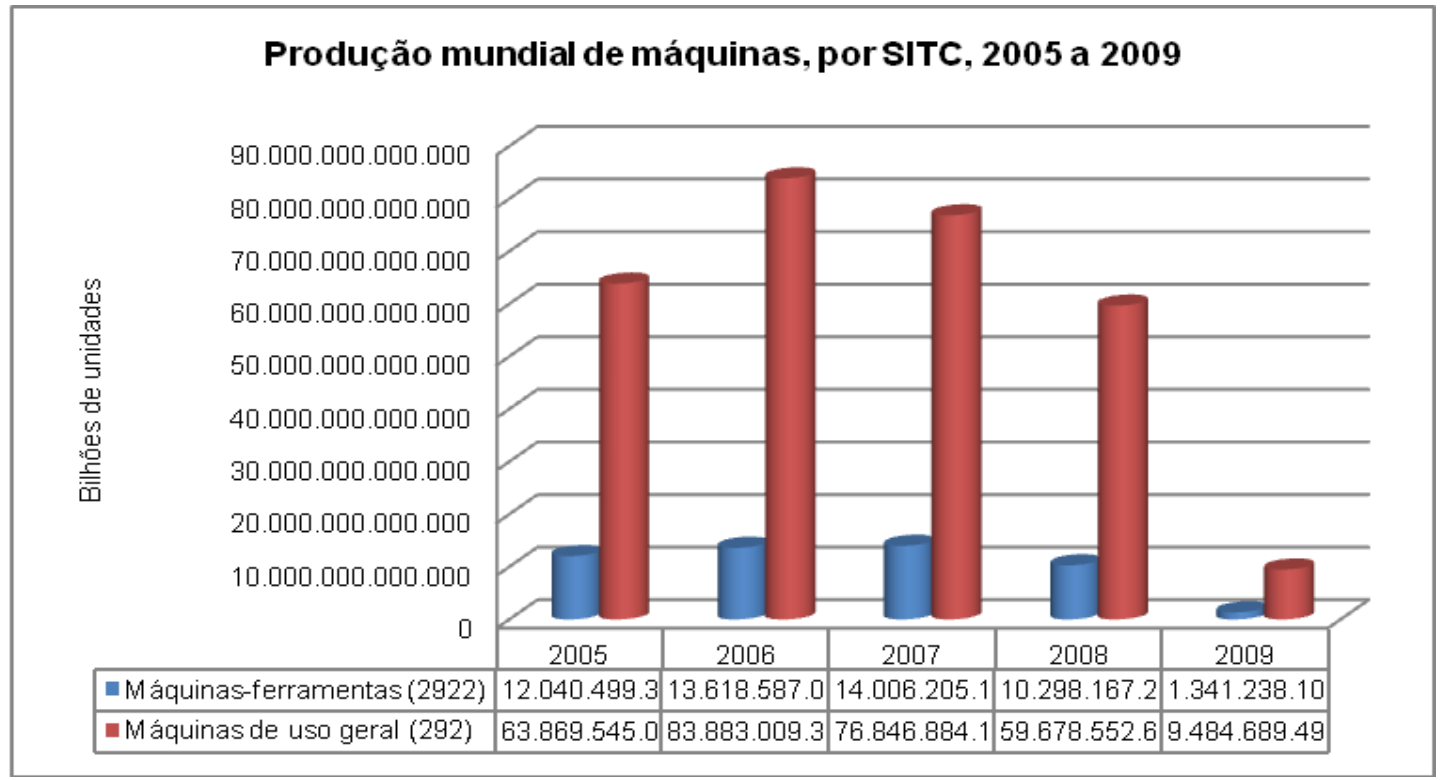

Fonte: Elaboração própria, com base nos dados da Statistics Division, United Nations Industrial Development Organization (UNIDO). Disponível em: http://data.un.org/Data.aspx?d=UNIDO\&f=tableCode\%3a04. Acesso em: 04/out/12.

No período entre 2005 e 2006, o setor de máquinas-ferramenta apresentou crescimento de $13 \%$ do volume de sua produção, acompanhando o movimento verificado pelo grupo de máquinas especiais que aumentou a produção em 31\%. Entretanto, nos três anos seguintes ambos os setores apresentaram queda do desempenho da produção de máquinas ${ }^{27}$.

Um dos principais fatores que pode explicar esses indicadores sobre número de empresas, dados de emprego e a produção mundial de máquinasferramenta é a queda da demanda agregada por máquinas e a redução da perspectiva de investimentos no cenário internacional nos anos de 2007 a 2009.

A partir da análise sobre o desempenho entre os principais países com atuação no ramo de máquinas-ferramenta é possível tecer outras considerações.

De maneira geral, a produção de máquinas-ferramenta por origem está concentrada historicamente em um pequeno número de países desenvolvidos:

\footnotetext{
27 A United Nations Industrial Commodity Statistics Database disponibiliza dados estatísticos sobre produção por categorias de produtos e por países. Os dados estão disponíveis em termos de unidades físicas e unidade monetária, e cobrem o período de 1995 a 2008. A soma do total produzido por tipo de produto (cinco dígitos) do ramo de máquina-ferramenta em 2008 não apresentou equivalência com dados agregados do ramo de máquina-ferramenta para o mesmo ano. Por esse motivo, a tese não utilizou os dados de produção de máquinas-ferramenta por tipo de produto.
} 
Alemanha, Japão, Itália e EUA. Entretanto, nos últimos anos da década passada os países do leste asiático, especialmente, China e Taiwan, e a Coréia do Sul começaram a participar na produção mundial de máquinas.

O gráfico $4.4^{28}$ apresenta dados sobre o valor da produção do ramo de máquinas-ferramenta no cenário mundial, considerando os principais países com participação nesse setor no período entre 2008 e 2011.

Gráfico 4.4 - Produção de máquinas-ferramenta em países selecionados (1), 2008-2011.

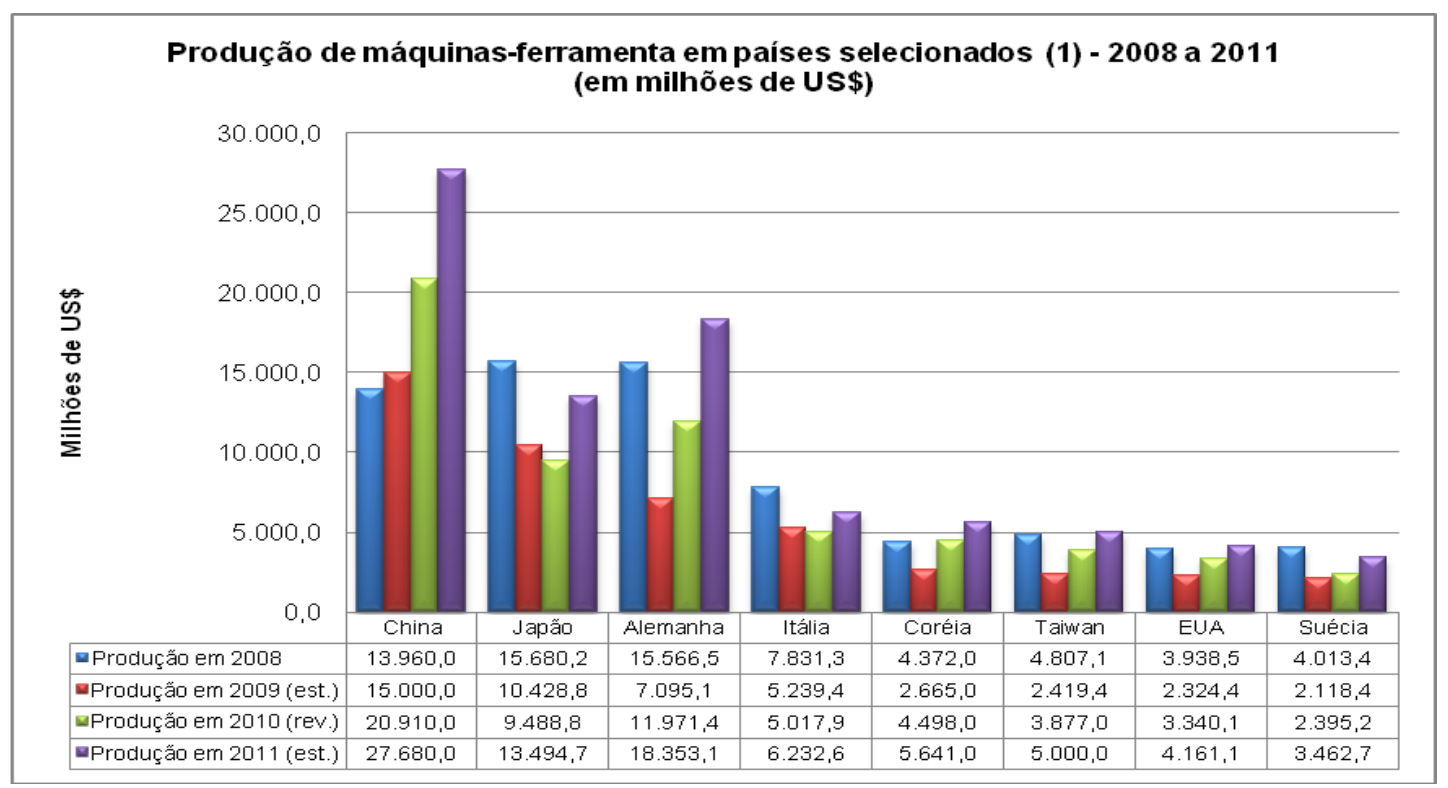

Fonte: Elaboração própria com base nos dados de Gardner (2012). World Machine Tool output \& consumption survey, 2012 e 2010.

De maneira geral, os países com maior participação na produção de máquinas apresentaram queda de sua produção no ano de 2009 e uma ligeira recuperação no ano de 2011.

Apesar das dificuldades no comércio mundial em virtude da crise econômica de 2008, a China apresentou crescimento do valor de produção de US\$13.960 milhões para US\$15.000 milhões em 2009. A Alemanha e o Japão, por sua vez, apresentaram queda expressiva do valor de produção de máquinas-ferramenta, respectivamente de US\$10.428 milhões (US\$ 15.680 milhões em 2008) e US\$ 7.095 milhões (US\$ 15.566 milhões em 2008).

Outro fator importante é que em 2011 a China, Japão e Alemanha apresentaram aumento do valor da produção de máquinas-ferramenta de

\footnotetext{
${ }^{28}$ Abrange os países líderes na produção de máquinas-ferramenta (em US\$ milhões): China, Japão, Alemanha, Itália, Coréia do Sul, Taiwan, EUA e Suécia.
} 
maneira mais expressiva, se comparado com o desempenho do valor da produção da Itália, Coréia do Sul, Taiwan, EUA e Suécia.

É possível identificar uma diferença no desempenho entre os três primeiros países e os demais países que se destacam no valor da produção mundial do setor de máquinas-ferramenta: os três países com maior participação também apresentaram melhores condições para recuperar seu desempenho nos anos de 2010 e 2011. O gráfico 4.5 apresenta dados considerando os países que ocupam as posições de $9^{\circ}$ produtor até $015^{\circ}$ produtor de máquinas-ferramenta no cenário mundial.

Gráfico 4.5 - Produção de máquinas-ferramenta em países selecionados (2) - 2008 a 2011

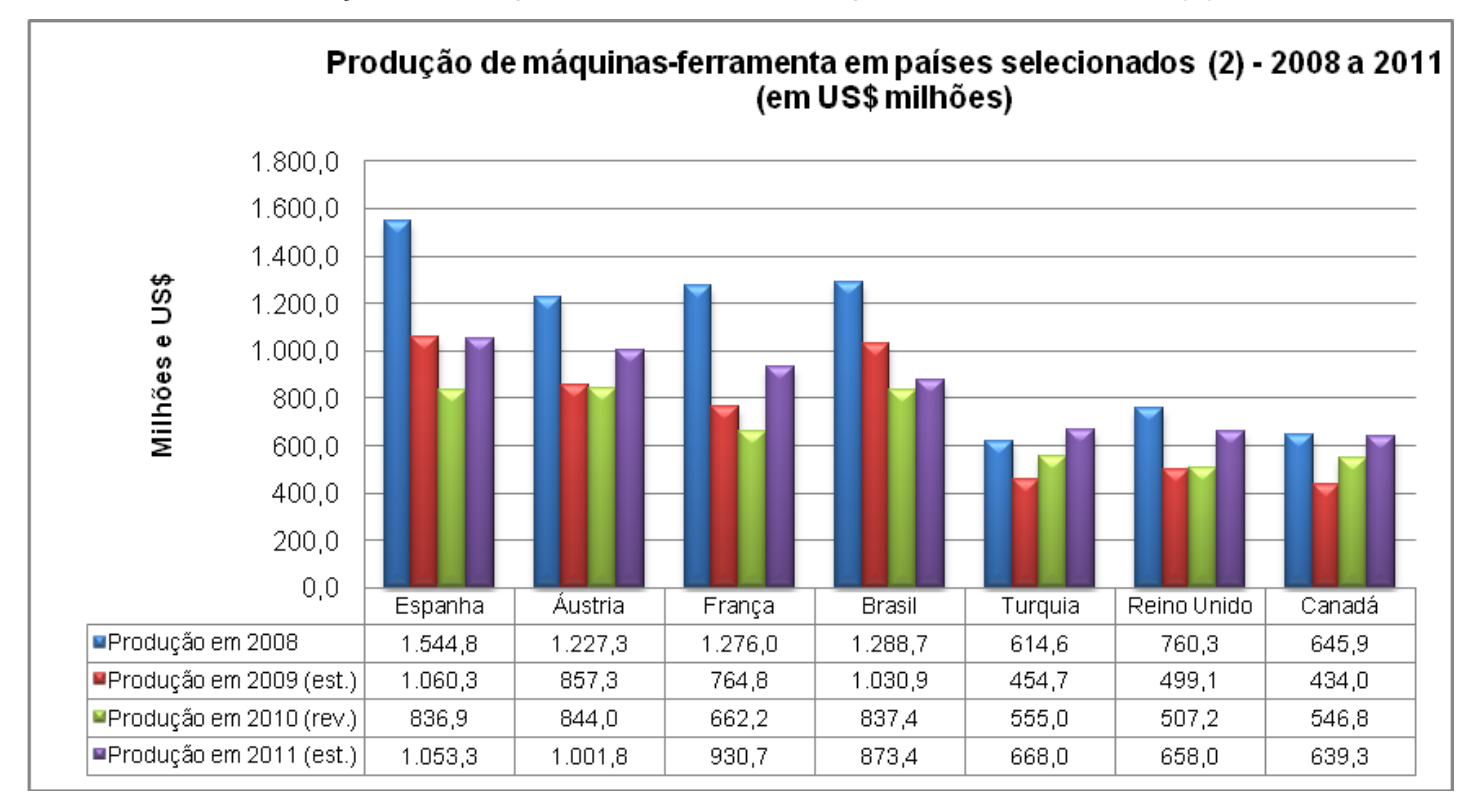

Fonte: Elaboração própria, com base nos dados de Gardner (2012). World Machine Tool output \& consumption survey, 2012 e 2010.

Os países deste grupo apresentaram média de 30\% de declínio do valor da produção de máquinas-ferramenta no ano de 2009, sendo a Espanha, a Áustria e a França os países que mais reduziram seu desempenho no período 2008-2009.

A partir de 2010, a França, o Reino Unido, a Espanha e a Turquia apresentaram recuperação mais expressiva do valor de produção de máquinas (média de $30 \%$ ), relativamente aos demais países deste grupo (média de 13\% de crescimento).

O consumo mundial de máquinas-ferramenta também apresenta alta concentração entre os países. De acordo com o estudo publicado pela Gardner 
Publications, todos os países apresentaram crescimento do consumo de máquinas-ferramenta no período 2010-2011.

Os países com maior consumo de máquinas-ferramenta em 2011 foram China, Japão, Alemanha, EUA e Coréia. A China foi o maior consumidor mundial de máquinas-ferramenta em 2011, com consumo de US $\$ 38.370$ milhões em 2011, o que representa crescimento de $34,7 \%$ em relação ao consumo de US\$28.480 em 2010 milhões.

Apesar de apresentar a maior participação no consumo mundial de máquinas-ferramenta, a China não apresentou maior crescimento relativo do consumo de máquinas no período 2010-201. O gráfico 4.6 ilustra os dados do consumo mundial de máquinas-ferramenta do Japão, Alemanha, EUA, Coréia do Sul, Itália, Índia, Brasil e Taiwan.

Gráfico 4.6 - Consumo mundial de máquinas-ferramenta - 2000 a 2010

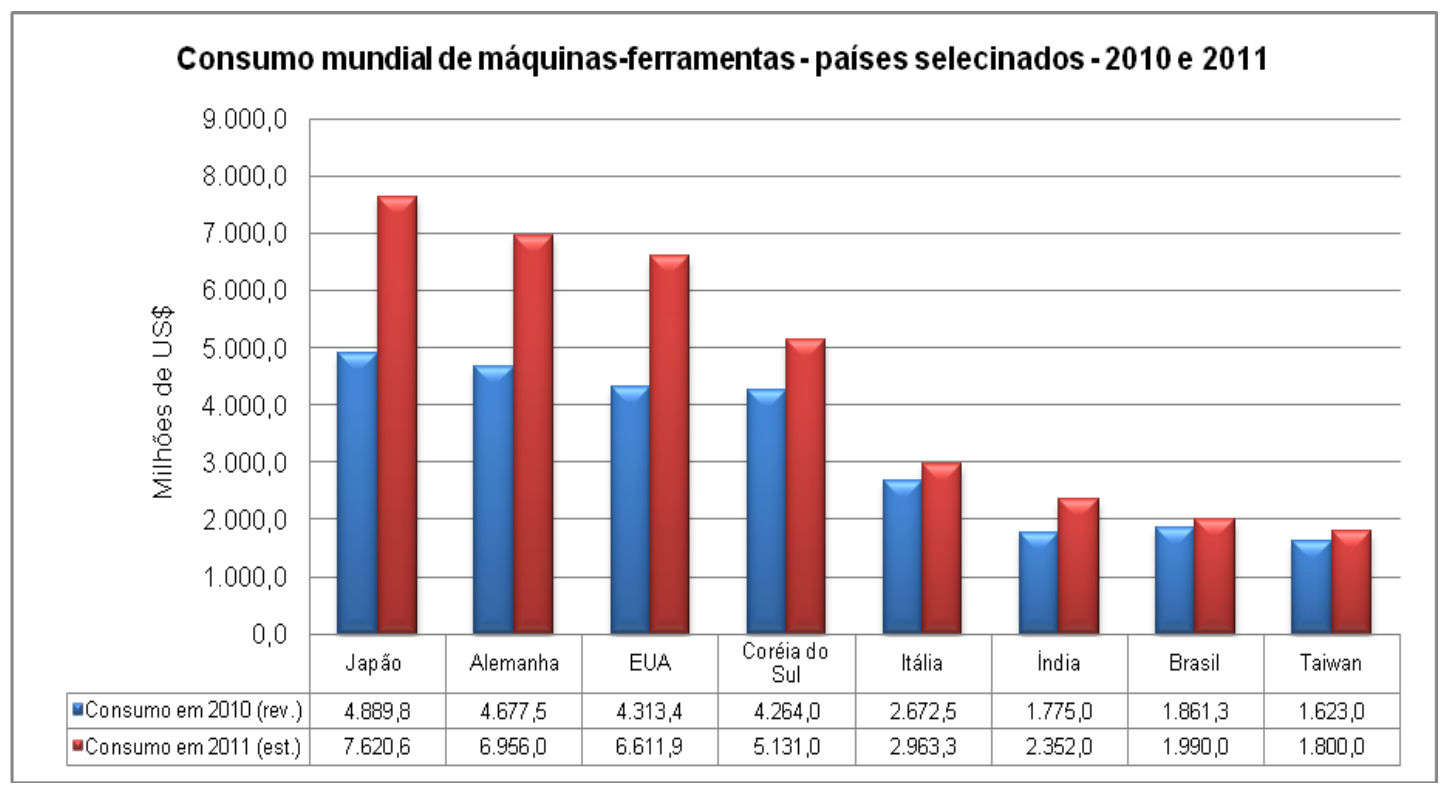

Fonte: Elaboração própria, com base nos dados de Gardner (2012) World Machine Tool output \& consumption survey, 2012 e 2010.

De acordo com gráfico 4.6, o Japão, a Alemanha e os EUA apresentaram crescimento, respectivamente, de 55,5\%; 48,7 e 53,3\% no consumo de máquinas no ano de 2011 em relação a 2010.

As estatísticas sobre comércio internacional de máquinas também constituem importante instrumento para compreender o desempenho dos segmentos de máquinas no cenário mundial. 
A indústria de bens de capital é uma das primeiras a responder às flutuações da atividade econômica internacional e uma das últimas a retomar os investimentos voltados à expansão ou modernização da capacidade produtiva. Entretanto, alguns segmentos do setor de máquinas podem sofrer mais o impacto das flutuações econômicas. Nesse sentido, a análise do comércio internacional por categorias de produtos pode ajudar a compreender a dinâmica comercial do setor entre os ramos de máquinas.

A Standard International Trade Classification classifica o setor de máquinas-ferramenta (Metalworking machinery) em quatro divisões (quadro 4.6). As divisões classificadas com os códigos SITC 731 e 733 apresentam as máquinas-ferramenta de maneira estrita, enquanto as divisões SITC 735 e 735 descrevem partes e equipamentos ${ }^{29}$.

\begin{tabular}{|c|l|}
\hline SITC & \multicolumn{1}{c|}{ Descrição dos produtos } \\
\hline 731 & Máquinas-ferramenta que trabalhem por eliminação de metal ou outro material \\
\hline 733 & $\begin{array}{l}\text { Máquinas-ferramenta para trabalhar metais, carbonetos metálicos sinterizados ou } \\
\text { ceramais, sem eliminação de material }\end{array}$ \\
\hline 735 & $\begin{array}{l}\text { Partes, não especificados, e acessórios reconhecíveis como exclusiva ou principalmente } \\
\text { destinados às máquinas incluídas nos grupos 731 e 733. }\end{array}$ \\
\hline 737 & $\begin{array}{l}\text { Máquinas para metais (exceto máquinas-ferramenta), e suas partes, não especificadas } \\
\text { anteriormente. }\end{array}$ \\
\hline
\end{tabular}

Quadro 4.6 - Descrição dos segmentos pertencentes ao setor Metalworking machinery

O gráfico 4.7 apresenta os dados sobre exportações mundiais de máquinas-ferramenta no período entre 2000 e 2010.

\footnotetext{
${ }^{29}$ Os segmentos SITC 731 e 732 podem ser divididos em outras classes e tipos de produtos. As informações sobre essas classificações podem ser consultadas no Anexo A.
} 
Gráfico 4.7 - Exportações mundiais de máquinas-ferramenta - 2000 a 2010

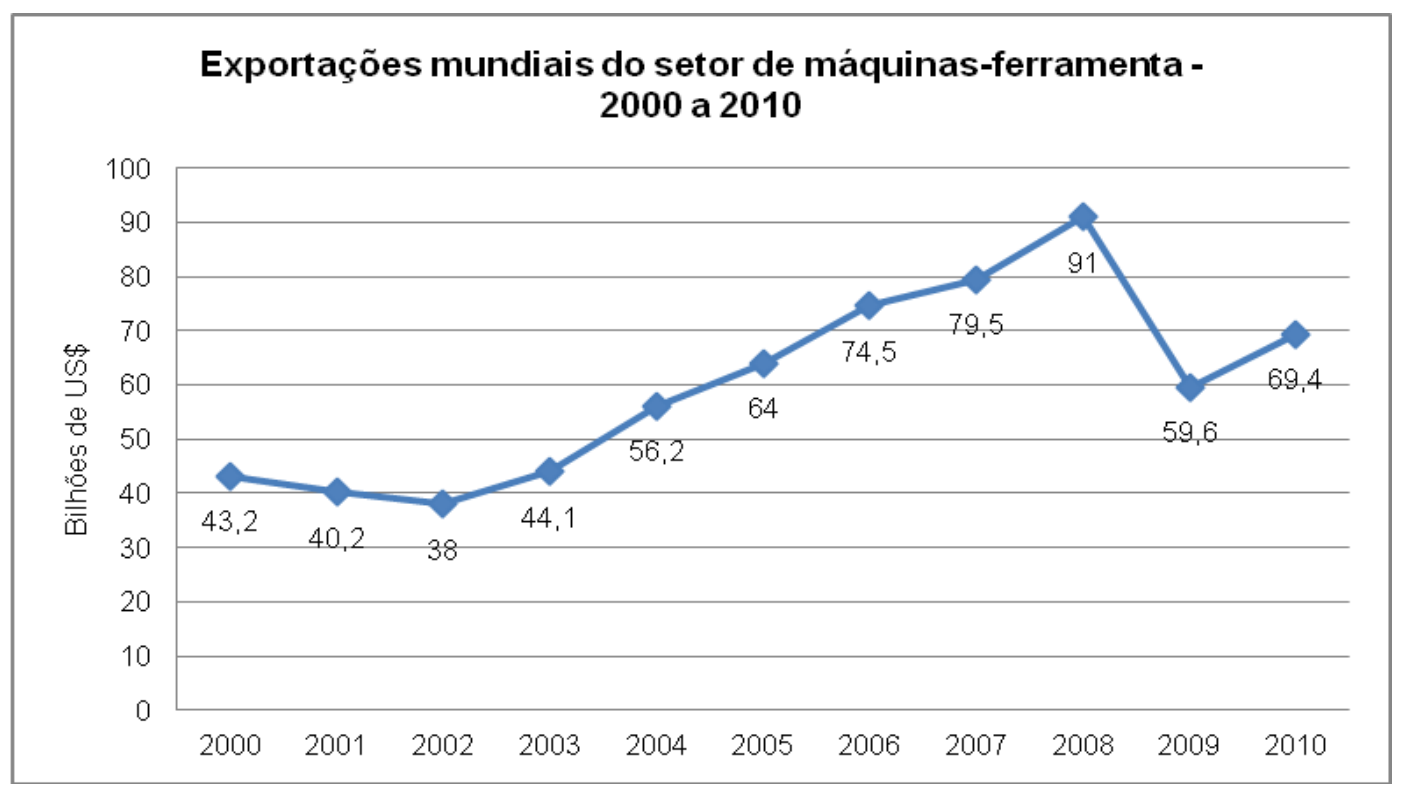

Fonte: Elaboração própria, com dados de Comtrade..

De acordo com os dados do gráfico, é possível destacar que as exportações mundiais de máquina-ferramenta apresentaram crescimento de US\$ 38 bilhões em 2002 para US\$ 91 bilhões em 2008. Entretanto, no ano de 2009 a crise internacional repercutiu em queda das exportações para o patamar de US\$ 59,6 bilhões em máquinas-ferramenta.

O gráfico 4.9 apresenta o desempenho do valor das exportações e importações de máquinas, por SITC a três dígitos, no período de 2000 a 2010. 
Gráfico 4.8 - Exportações mundiais do setor de máquinas e equipamentos, por SITC - 2000 a 2010

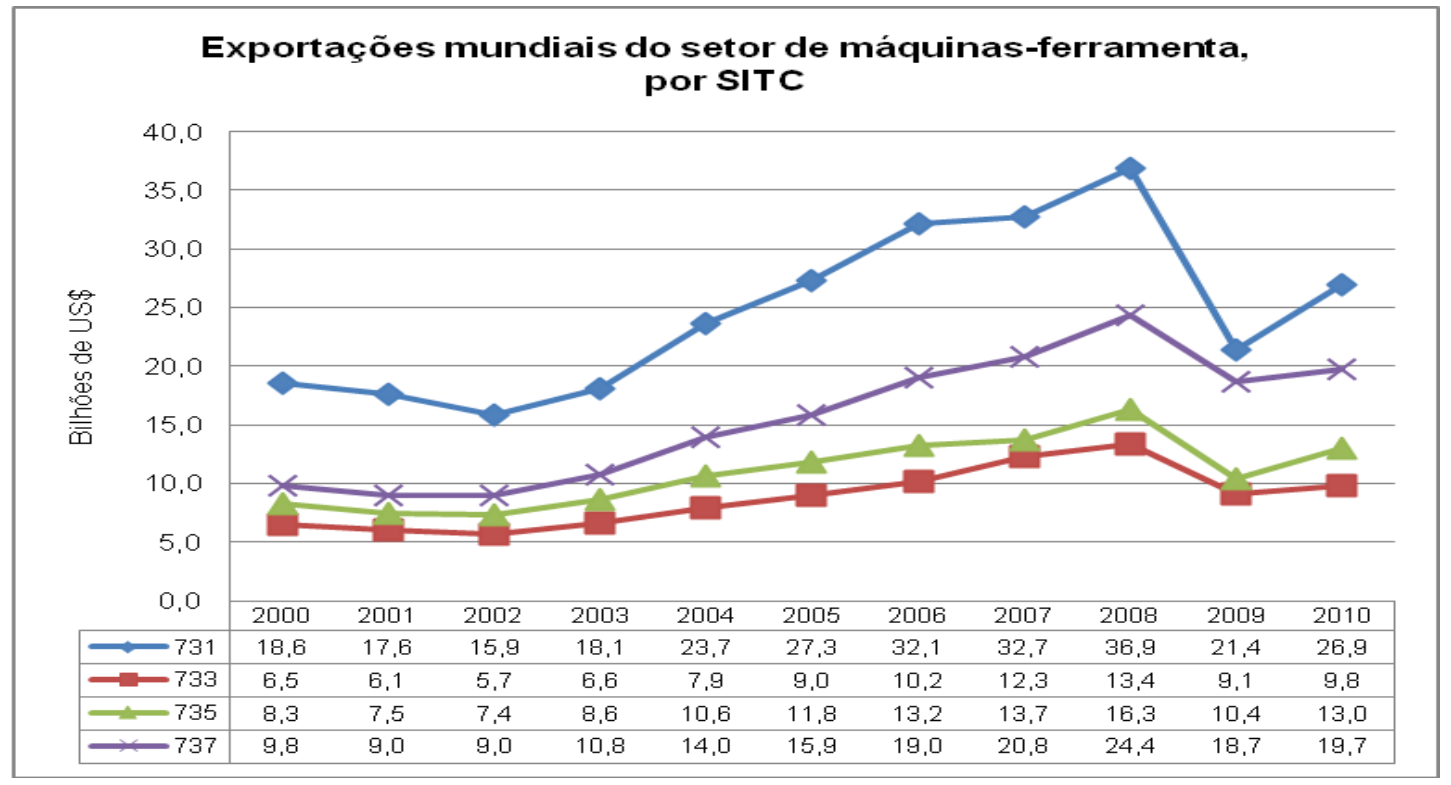

Fonte: Elaboração própria, com dados de Comtrade e SITC Rev. 4 .

SITC 73: Metalworking machinery. Acesso em: 31/março/11. Atualizado em 04/outubro/12.

No ano de 2008, a crise econômica internacional repercutiu negativamente no desempenho das exportações de todos os ramos de máquinas-ferramenta.

O segmento de máquinas que trabalham com eliminação de metal ou outros materiais (SITC 731) apresentou queda mais brusca de suas vendas externas relativamente aos outros setores industriais. O gráfico 4.7 apresenta a participação dos tipos de produtos (por SITC) no total de exportações do setor de máquinas-ferramenta. 
Gráfico 4.9 - Participação dos segmentos de máquinas no total de exportações do setor 2000 a 2010

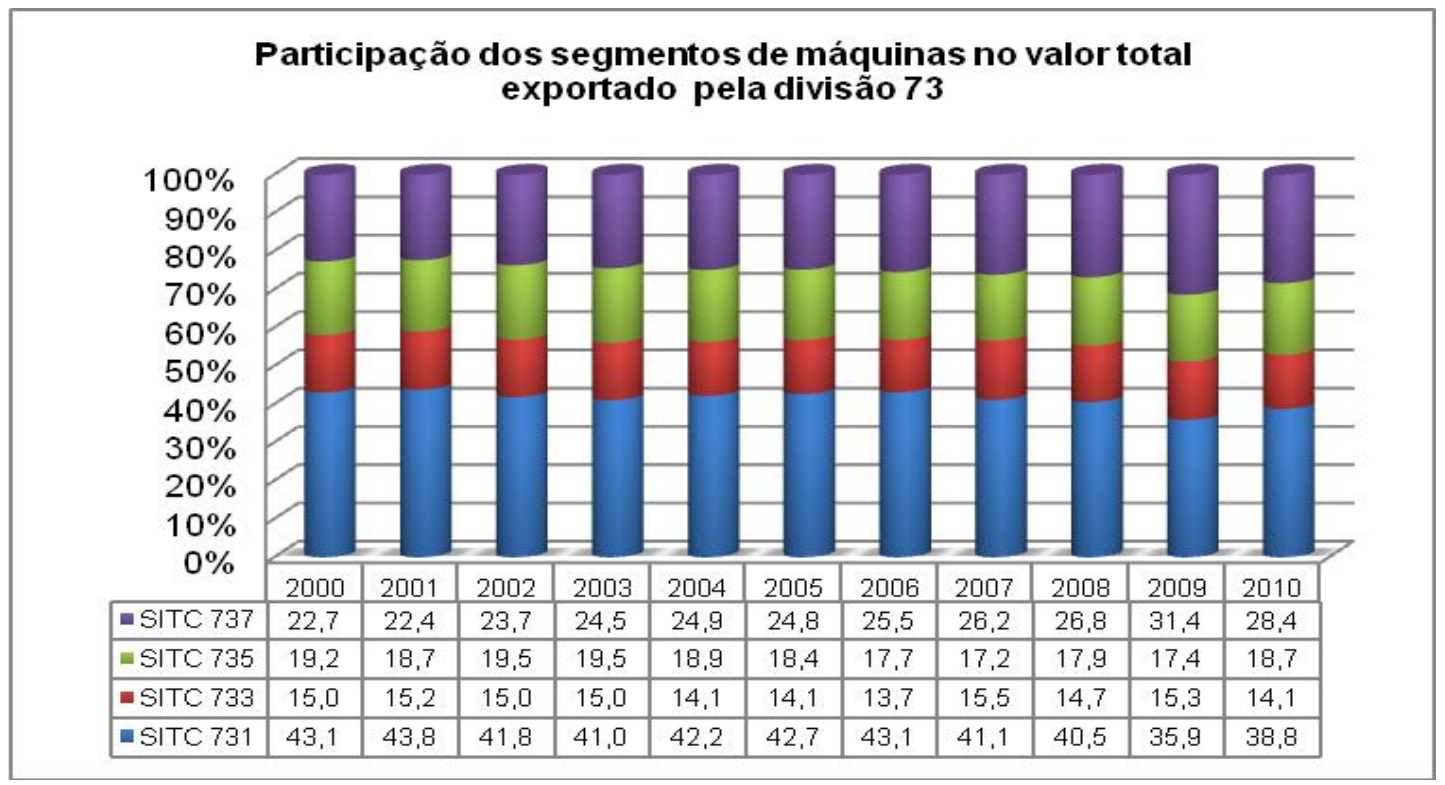

Fonte: Elaboração própria, com dados de Comtrade e SITC Rev. 4 .

SITC 73: Metalworking machinery. Acesso em: 31/março/11. Atualizado em 04/outubro/12.

No período de 2000 a 2010, os segmentos que apresentaram maior participação no total de exportações do setor de máquinas-ferramenta são aqueles que fabricam máquinas para trabalhar metal ou outros materiais com eliminação de material (SITC 731) e sem eliminação de metal (SITC 733).

A análise mais detalhada do comércio mundial de máquinas-ferramenta considerando os países de origem e destino das máquinas-ferramenta e as categorias de máquinas que trabalham com eliminação de material (SITC 731) e sem eliminação de material (SITC 733) podem ajudar a compreender a dinâmica do comércio internacional de máquinas-ferramenta. As tabelas $4.1 \mathrm{e}$ 4.2 apresentam os principais países com participação no comércio exterior no ramo de máquinas-ferramenta que trabalha por eliminação de metal ou outro material (SITC 731). 
Tabela 4.1 - Exportações de máquinas-ferramenta que trabalham metal, por eliminação de metal ou outro material (SIT 731), principais países, 2009 e 2010.

\begin{tabular}{|c|c|c|c|c|c|c|}
\hline & Países & $\begin{array}{l}\text { Exportações } \\
\text { em 2009 } \\
\text { (US\$ milhões) }\end{array}$ & $\begin{array}{l}\text { Participação } \\
\text { no total de } \\
\text { exportações } \\
\text { do setor } \\
(\%)\end{array}$ & Países & $\begin{array}{l}\text { Exportações } \\
\text { em } 2010 \\
\text { (US\$ milhões) }\end{array}$ & $\begin{array}{c}\text { Participaçã } \\
\text { o no total } \\
\text { de } \\
\text { exportaçõe } \\
\text { s do setor } \\
(\%)\end{array}$ \\
\hline 1 & Alemanha & $5.317,1$ & 24,7 & Japão & $6.950,3$ & 25,8 \\
\hline 2 & Japão & $3.445,5$ & 16,0 & Alemanha & $5.013,2$ & 18,6 \\
\hline 3 & Itália & $1.888,7$ & 8,8 & Outros Ásia & $2.319,5$ & 8,6 \\
\hline 4 & Suíça & $1.479,4$ & 6,9 & Itália & $1.818,2$ & 6,8 \\
\hline 5 & EUA & $1.336,1$ & 6,2 & Suíça & $1.727,1$ & 6,4 \\
\hline 6 & Outros Ásia & $1.324,2$ & 6,2 & EUA & $1.652,7$ & 6,1 \\
\hline 7 & China Hong Kong & 954,2 & 4,4 & China & $1.284,2$ & 4,8 \\
\hline 8 & Coréia & 863 & 4,0 & Coréia & $1.180,9$ & 4,4 \\
\hline 9 & Espanha & 632,7 & 2,9 & República Tcheca & 500,2 & 1,9 \\
\hline 10 & República Tcheca & 532,2 & 2,5 & Bélgica & 424,9 & 1,6 \\
\hline 11 & Bélgica & 427,5 & 2,0 & Reino Unido & 411,0 & 1,5 \\
\hline 12 & Reino Unido & 409 & 1,9 & Espanha & 394,4 & 1,5 \\
\hline 13 & Áustria & 397,9 & 1,8 & Áustria & 390,7 & 1,5 \\
\hline 14 & França & 310,7 & 1,4 & China, Hong Kong & 388,2 & 1,4 \\
\hline \multirow[t]{3}{*}{15} & Singapura & 212,8 & 1,0 & Singapura & 356,7 & 1,3 \\
\hline & Subtotal & $19.531,0$ & 90,8 & Subtotal & $24.812,2$ & 92,2 \\
\hline & Total (mundo) & $21.514,0$ & & Total (mundo) & $26.899,2$ & \\
\hline
\end{tabular}

Fonte: Elaboração própria, com dados de United Nations Commodity Trade Statistics Database (UN Comtrade).

Disponível em: http://comtrade.un.org/db/ce/ceSnapshot.aspx?px=S4\&cc=73. Acesso em 14/out/12.

Tabela 4.2 - Importações de máquinas-ferramenta que trabalham metal, por eliminação de metal ou outro material (SIT 731), por países selecionados, 2009 e 2010.

\begin{tabular}{|c|c|c|c|c|c|c|}
\hline & Países & $\begin{array}{c}\text { Importações } \\
\text { em } 2009 \\
\text { (US\$ milhões) }\end{array}$ & $\begin{array}{l}\text { Participação } \\
\text { no total de } \\
\text { importações } \\
\text { do setor } \\
(\%) \\
\end{array}$ & Países & $\begin{array}{c}\text { Importações } \\
\text { em } 2010 \\
\text { (US\$ } \\
\text { milhões) }\end{array}$ & $\begin{array}{c}\text { Participação } \\
\text { no total de } \\
\text { importações } \\
\text { do setor } \\
(\%) \\
\end{array}$ \\
\hline 1 & China & $4.559,0$ & 21,3 & China & $7.526,3$ & 28,8 \\
\hline 2 & EUA & $1.926,8$ & 9,0 & EUA & $2.248,30$ & 8,6 \\
\hline 3 & Alemanha & $1.857,7$ & 8,7 & Alemanha & $1.530,1$ & 5,9 \\
\hline 4 & Coréia & 808,4 & 3,8 & Coréia & $1.145,6$ & 4,4 \\
\hline 5 & Itália & 708,1 & 3,3 & Índia & 836,3 & 3,2 \\
\hline 6 & Índia & 687,9 & 3,2 & Tailândia & 822,5 & 3,2 \\
\hline 7 & Rússia & 685,8 & 3,2 & Rússia & 704,9 & 2,7 \\
\hline 8 & França & 610,3 & 2,8 & Itália & 675,7 & 2,6 \\
\hline 9 & México & 530,0 & 2,5 & Outros Ásia & 572,2 & 2,2 \\
\hline 10 & Bélgica & 494,2 & 2,3 & Brasil & 566,8 & 2,2 \\
\hline 11 & Brasil & 476,6 & 2,2 & México & 541,6 & 2,1 \\
\hline 12 & Tailândia & 437,3 & 2,0 & França & 529 & 2,0 \\
\hline 13 & Suíça & 433,2 & 2,0 & Turquia & 485,4 & 1,9 \\
\hline 14 & Vietnã & 426,5 & 2,0 & Reino Unido & 448,6 & 1,7 \\
\hline \multirow[t]{3}{*}{15} & Polônia & 397,9 & 1,9 & Canadá & 436,3 & 1,7 \\
\hline & Subtotal & $15.039,7$ & 70,2 & Subtotal & $19.069,6$ & 73,0 \\
\hline & Total (mundo) & $21.438,5$ & 100,0 & Total (mundo) & 26109,2 & 100,0 \\
\hline
\end{tabular}

Fonte: Elaboração própria, com dados de United Nations Commodity Trade Statistics Database (UN Comtrade).

Disponível em: http://comtrade.un.org/db/ce/ceSnapshot.aspx?px=S4\&cc=73. Acesso em 14/out/12. 
De acordo com dados da tabela 4.1, os principais países com participação nas exportações da categoria SITC 731 no período de 2009 e 2010 são Japão, Alemanha, Itália, Suíça, EUA e Outros países da Ásia. Esses países foram responsáveis por certa de $70 \%$ do valor total das exportações daquela categoria de produto. Além disso, em 2010 o grupo de Outros países (inclui Taiwan) ocupou a posição da Itália entre os países lideres na exportação de máquinas.

Considerando os dados da tabela 4.2 sobre importações da categoria máquinas-ferramenta que eliminam metal ou outro material, os países com maior participação nas importações totais dessas máquinas foram China, EUA, Alemanha e Coréia. Nos anos de 2009 e 2010 esses quatro países responderam por aproximadamente $45 \%$ do valor das importações de máquinas. Em 2010, a Itália perdeu três posições para a Índia, Rússia e Tailândia. As tabelas 4.3 e 4.4 apresentam os principais países com participação no comércio exterior no ramo de máquinas-ferramenta para trabalhar metais sem eliminação de materiais (SITC 733).

Tabela 4.3 - Exportações de máquinas-ferramenta que trabalham metal, sem eliminação de material (SIT 733), por países selecionados, 2009 e 2010.

\begin{tabular}{|c|c|c|c|c|c|c|}
\hline & Países & $\begin{array}{c}\text { Exportações } \\
\text { em } 2009 \\
\text { (US\$ milhões) }\end{array}$ & $\begin{array}{l}\text { Participação } \\
\text { no total de } \\
\text { exportações } \\
\text { do setor } \\
(\%)\end{array}$ & Países & $\begin{array}{c}\text { Exportações } \\
\text { em } 2010 \\
\text { (US\$ } \\
\text { milhões) }\end{array}$ & $\begin{array}{c}\text { Participação } \\
\text { no total de } \\
\text { exportações } \\
\text { do setor } \\
(\%)\end{array}$ \\
\hline 1 & Alemanha & $1.823,3$ & 20,2 & Alemanha & $1.593,50$ & 16,3 \\
\hline 2 & Itália & $1.490,5$ & 16,5 & Itália & 1444,4 & 14,7 \\
\hline 3 & Japão & 913,8 & 10,1 & Japão & 1142,1 & 11,6 \\
\hline 4 & EUA & 645,4 & 7,2 & EUA & 809,6 & 8,3 \\
\hline 5 & China & 457,5 & 5,1 & Outros Ásia & 628,1 & 6,4 \\
\hline 6 & Outros Ásia & 419,7 & 4,7 & China & 571,5 & 5,8 \\
\hline 7 & Suíça & 353,3 & 3,9 & Coréia & 500,9 & 5,1 \\
\hline 8 & Coréia & 349,5 & 3,9 & Áustria & 342,5 & 3,5 \\
\hline 9 & Bélgica & 258,4 & 2,9 & Suíça & 336,1 & 3,4 \\
\hline 10 & Áustria & 248,8 & 2,8 & Espanha & 247,4 & 2,5 \\
\hline 11 & Espanha & 242,3 & 2,7 & Turquia & 241,7 & 2,5 \\
\hline 12 & França & 229,3 & 2,5 & Bélgica & 221,9 & 2,3 \\
\hline 13 & Turquia & 225,8 & 2,5 & Reino Unido & 215,3 & 2,2 \\
\hline 14 & Reino Unido & 151,0 & 1,7 & França & 213,3 & 2,2 \\
\hline \multirow[t]{3}{*}{15} & Finlândia & 102,2 & 1,1 & Holanda & 108,8 & 1,1 \\
\hline & Subtotal & $7.910,8$ & 87,7 & Subtotal & $8.617,10$ & 87,9 \\
\hline & Total (mundo) & $9.024,7$ & & Total mundo & $9.804,4$ & 100,0 \\
\hline
\end{tabular}

Fonte: Elaboração própria, com dados de United Nations Commodity Trade Statistics Database (UN Comtrade).

Disponível em: http://comtrade.un.org/db/ce/ceSnapshot.aspx?px=S4\&cc=73. Acesso em 14/out/12. 
Tabela 4.4 - Importações de máquinas-ferramenta que trabalham metal, sem eliminação de material (SIT 733), por países selecionados, 2009 e 2010.

\begin{tabular}{|c|c|c|c|c|c|c|}
\hline & Países & $\begin{array}{l}\text { Importações } \\
\text { em } 2009 \\
\text { (US\$ milhões) }\end{array}$ & $\begin{array}{l}\text { Participação } \\
\text { no total de } \\
\text { importações } \\
\text { do setor } \\
(\%) \\
\end{array}$ & Países & $\begin{array}{c}\text { Importações } \\
\text { em } 2010 \\
\text { (US\$ } \\
\text { milhões) }\end{array}$ & $\begin{array}{l}\text { Participação } \\
\text { no total de } \\
\text { importações } \\
\text { do setor } \\
(\%) \\
\end{array}$ \\
\hline 1 & China & $1.338,0$ & 14,0 & China & $1.892,1$ & 18,9 \\
\hline 2 & EUA & 565,6 & 5,9 & EUA & 561,9 & 5,6 \\
\hline 3 & Índia & 509,9 & 5,3 & Tailândia & 433,9 & 4,3 \\
\hline 4 & Brasil & 420,6 & 4,4 & Rússia & 414,1 & 4,1 \\
\hline 5 & Rússia & 386,9 & 4,0 & México & 394,8 & 3,9 \\
\hline 6 & México & 386,9 & 4,0 & Alemanha & 374,9 & 3,7 \\
\hline 7 & Vietnã & 369,8 & 3,9 & Brasil & 374,7 & 3,7 \\
\hline 8 & Alemanha & 361,4 & 3,8 & Vietnã & 340,0 & 3,4 \\
\hline 9 & Coréia & 324,6 & 3,4 & Índia & 333,9 & 3,3 \\
\hline 10 & Tailândia & 286,4 & 3,0 & Malásia & 329,1 & 3,3 \\
\hline 11 & França & 222,1 & 2,3 & Coréia & 290,6 & 2,9 \\
\hline 12 & Polônia & 212,1 & 2,2 & Itália & 247,6 & 2,5 \\
\hline 13 & Espanha & 205,5 & 2,1 & Turquia & 205,5 & 2,0 \\
\hline 14 & Turquia & 192,1 & 2,0 & Indonésia & 183,9 & 1,8 \\
\hline \multirow[t]{3}{*}{15} & Itália & 191,8 & 2,0 & Bélgica & 175,9 & 1,8 \\
\hline & Subtotal & $5.973,7$ & 62,5 & Subtotal & $6.552,9$ & 65,3 \\
\hline & Total (mundo) & $9.562,1$ & 100,0 & Total (mundo) & $10.037,2$ & 100,0 \\
\hline
\end{tabular}

De acordo com dados da tabela acima, os principais países com participação nas exportações da categoria de máquinas sem eliminação de material (SITC 733) no período de 2009 e 2010 são Alemanha, Itália, Japão, EUA, China e Outros países da Ásia.

No período considerado, esses seis países foram responsáveis por cerca de $63 \%$ do valor total das exportações daquela categoria de produto.

Considerando os dados da tabela 4.4 sobre importações da categoria máquinas sem eliminação de material, os países com maior participação nas importações totais dessas máquinas foram China e EUA. Nos anos de $2009 \mathrm{e}$ 2010 esses países responderam por aproximadamente 23\% do valor das importações de máquinas.

As alterações no desempenho e perfil das exportações e importações de máquinas-ferramenta por países e por produtos podem refletir as mudanças estruturais do setor de máquinas-ferramenta mundial. As tabelas 4.5 e 4.6 
apresentam o índice de concentração das exportações e importações de máquinas-ferramenta no mercado internacional, por nível de atividade ${ }^{30}$.

Tabela 4.5 - Índice de concentração das exportações de Máquinas-ferramenta

\begin{tabular}{llcc}
\hline \multicolumn{1}{c}{ Descrição do SITC } & \multicolumn{3}{c}{ Índice de concentração das exportações } \\
$\mathbf{2 0 0 0}$ & $\mathbf{2 0 0 5}$ & $\mathbf{2 0 0 9}$ \\
\hline $\begin{array}{l}\text { Máquinas-ferramenta que trabalhem } \\
\text { por eliminação de metal ou outro } \\
\text { material }\end{array}$ & 0,347 & 0,325 & 0,288 \\
$\begin{array}{l}\text { Máquinas-ferramenta sem eliminação } \\
\text { de materiais }\end{array}$ & 0,261 & 0,258 & 0,257 \\
$\begin{array}{l}\text { Partes não especificados, e acessórios } \\
\text { destinados às máquinas incluídas nos } \\
\text { grupos 731 e 733 }\end{array}$ & 0,301 & 0,253 & 0,231 \\
$\begin{array}{l}\text { Máquinas para metais (exceto } \\
\text { máquinas-ferramenta), e suas partes, } \\
\text { não especificados anteriormente. }\end{array}$ & 0,251 & 0,227 & 0,252 \\
\hline
\end{tabular}

Fonte: Elaboração própria, com dados da Unctad Handbook of Statistic, 2010, p. 204-07.

Tabela 4.6 - Índice de concentração das importações de Máquinas-ferramenta

\begin{tabular}{|c|c|c|c|}
\hline \multirow{2}{*}{ Descrição do SITC } & \multicolumn{3}{|c|}{ İndice de concentração das importações } \\
\hline & 2000 & 2005 & 2009 \\
\hline $\begin{array}{l}\text { Máquinas-ferramenta que trabalhem } \\
\text { por eliminação de metal ou outro } \\
\text { material }\end{array}$ & 0,221 & 0,204 & 0,212 \\
\hline $\begin{array}{l}\text { Máquinas-ferramenta sem eliminação } \\
\text { de materiais }\end{array}$ & 0,203 & 0,191 & 0,144 \\
\hline $\begin{array}{l}\text { Partes não especificados, e } \\
\text { acessórios destinados às máquinas } \\
\text { incluídas nos grupos } 731 \text { e } 733\end{array}$ & 0,208 & 0,173 & 0,158 \\
\hline $\begin{array}{l}\text { Máquinas para metais (exceto } \\
\text { máquinas-ferramenta), e suas partes, } \\
\text { não especificados anteriormente. }\end{array}$ & 0,165 & 0,182 & 0,153 \\
\hline
\end{tabular}

Fonte: Elaboração própria, com dados da Unctad Handbook of Statistic, 2010, p. 208-11.

De maneira geral, a pauta de comércio internacional de máquinasferramenta pode ser caracterizada pela forte concentração em relação aos países importadores e exportadores de máquinas.

O setor de máquinas-ferramenta apresentou queda do índice de concentração das exportações no período entre 2000 e 2009, principalmente, nas atividades correspondentes ao SITC 731 e 735.

O índice de concentração das importações, por sua vez, tem apresentado queda menos expressiva (relativamente à concentração das exportações) nos três anos considerados.

\footnotetext{
30 Índice de concentração: Um valor do índice perto de 1 indica um mercado muito concentrado; enquanto o índice mais próximo de 0 refletem uma distribuição mais equitativa das quotas de mercado entre os exportadores ou importadores (UNIDO, 2010, p. 212 - tradução).
} 
A exceção pode ser atribuída ao setor de máquinas-ferramenta sem eliminação de materiais que apresentou mudança do índice de concentração das compras de 0,203; 0,191; e 0,144; e ao SITC $735(0,208 ; 0,173 ; 0,158$, respectivamente).

O estudo realizado pela Unctad (2010) também destaca o índice de mudança da estrutura das exportações e importações ${ }^{31}$ da indústria de máquinas-ferramenta no período entre 2000 e 2009 (tabela 4.7).

Tabela 4.7 - Índice de mudança estrutural das exportações e importações de Máquinasferramenta

\begin{tabular}{|c|c|c|c|c|}
\hline \multirow[t]{2}{*}{$\begin{array}{l}\text { Descrição do } \\
\text { SITC }\end{array}$} & \multicolumn{2}{|c|}{$\begin{array}{c}\text { Índice de mudança } \\
\text { estrutural das exportações }\end{array}$} & \multicolumn{2}{|c|}{$\begin{array}{l}\text { Índice de mudança } \\
\text { estrutural das } \\
\text { importações }\end{array}$} \\
\hline & 2000 & 2009 & 2000 & 2009 \\
\hline $\begin{array}{l}\text { Máquinas-ferramenta que } \\
\text { trabalhem por eliminação de } \\
\text { metal ou outro material }\end{array}$ & 0,061 & 0,259 & 0,142 & 0,309 \\
\hline $\begin{array}{l}\text { Máquinas-ferramenta sem } \\
\text { eliminação de materiais }\end{array}$ & 0,088 & 0,207 & 0,216 & 0,300 \\
\hline $\begin{array}{l}\text { Partes não especificados, e } \\
\text { acessórios destinados às } \\
\text { máquinas incluídas nos grupos } \\
731 \text { e } 733\end{array}$ & 0,120 & 0,186 & 0,093 & 0,212 \\
\hline $\begin{array}{l}\text { Máquinas para metais (exceto } \\
\text { máquinas-ferramenta), e suas } \\
\text { partes, não especificados } \\
\text { anteriormente. }\end{array}$ & 0,126 & 0,244 & 0,166 & 0,257 \\
\hline
\end{tabular}

A partir da análise e dados desta seção é possível destacar que no início da década de 2000, todas as categorias SITC 73 apresentavam a participação de países exportadores e importadores já com tradição no comércio internacional de máquinas-ferramenta.

Em especial, o menor índice para as exportações do setor de máquinas com eliminação de material (SITC 731) em 2000 pode indicar a forte presença de países desenvolvidos nas exportações da indústria. O menor índice para as importações do SITC 735, por sua vez, pode indicar a presença dos países de industrialização recente nas importações de máquinas.

Entretanto, a partir de 2007, esse perfil mudou de maneira significativa por conta de duas transformações no mercado mundial de máquinas.

\footnotetext{
31 Índice de mudança estrutural: $O$ índice próximo de 1 indica uma alteração significativa na composição de exportadores (importadores). Os valores próximos de 0 , demonstraria um maior grau de "tradicionalidade" nos mercados durante o período em questão (UNIDO, 2010, p. 212 - tradução).
} 
Em primeiro lugar, destaca-se que a crise econômica internacional repercutiu em queda da demanda de máquinas, o que refletiu no desempenho de todos os países na produção e comércio internacional de máquinas. Em segundo lugar, a inserção da China e Taiwan na produção mundial de máquinas-ferramenta influenciou a dinâmica econômica e industrial do setor de máquinas $^{32}$. O aumento do índice de mudança estrutural das exportações e das importações em 2009 pode indicar essa mudança no perfil do setor.

Os países que começaram a atuar na indústria de bens de capital concentram suas atividades em todos os segmentos de máquinas. No ramo de máquinas-ferramenta, os países asiáticos se tornaram grandes fabricantes de máquinas com baixa e média complexidade tecnológica; e grandes consumidores de máquinas com tecnologia embarcada mais sofisticada.

Nos últimos três anos, aqueles dois países asiáticos ocuparam a posição da Itália e EUA, que apresentam participação histórica no comércio internacional.

Apesar dessas transformações, o Japão e a Alemanha mantêm o seu desempenho na produção e no comércio mundial de máquinas. Outro fator importante é que aqueles países apresentaram rápida recuperação de suas exportações relativamente aos outros países líderes no comércio mundial de máquinas.

Em grande medida, esses resultados podem ser atribuídos às características do ambiente em que os setores estão inseridos, à dinâmica de desenvolvimento tecnológico e às relações entre os atores do Sistema Setorial de Inovação de máquinas-ferramenta dos países desenvolvidos. A próxima seção apresenta uma discussão sobre os principais países desenvolvidos com participação no mercado mundial de máquinas-ferramenta (Alemanha, Japão, Itália e EUA) à luz da discussão sobre Sistema Setorial de Inovação.

\footnotetext{
32 A tese não discutirá as características da dinâmica industrial e tecnológica do setor e o conceito de Sistema inovação de máquinas-ferramenta para os países asiáticos.
} 


\subsection{Considerações sobre o setor de máquinas-ferramenta em países selecionados}

Os principais países com participação histórica no setor de máquinasferramenta têm apresentado algumas características estruturais que ajudam a compreender o desempenho e as rupturas no padrão de mudança técnica do setor de máquinas-ferramenta.

O segmento de máquinas de países como EUA, Japão, Alemanha e Itália apresenta importante dinamismo em termos de produção e desenvolvimento tecnológico das máquinas. Entretanto, enquanto 0 desenvolvimento do setor na Europa é relativamente mais estável; o número de firmas de máquinas-ferramenta nos EUA é muito mais volátil (Wengel \& Shapira, 2001).

Essas características podem ser atribuídas, principalmente, a dois conjuntos de fatores. De um lado, destaca-se a atuação de instituições e agentes que forneceram as condições para o desenvolvimento do setor. De outro lado, destaca-se que a demanda interna e as características do ambiente econômico e industrial de cada país implicaram em diferentes condições para a criação, difusão e aprendizado de tecnologias.

A influência desses fatores pode ser abordada sob a perspectiva de Sistema Setorial de Inovação, que abrange os atores, instituições e redes de interações voltadas à inovação.

De maneira geral, os Sistemas Setoriais de Inovação de máquinasferramenta podem ser agrupados em duas categorias: tradicional e emergentes.

Os Sistemas Setoriais tradicionais reúnem as condições típicas do desenvolvimento industrial do setor de máquinas-ferramenta, como resultado da formação histórica do setor através dos países. Os Sistemas Setoriais emergentes, por sua vez, apresentam maior variedade e complexidade de condições para o desenvolvimento inovativo das máquinas. Esse fator pode ser atribuído às transformações verificadas entre os segmentos de máquinas a partir de meados dos anos 90.

Desde o início do desenvolvimento do setor de máquinas-ferramenta, a interdependência entre diferentes áreas de conhecimento assumiu papel 
significativo para o desenvolvimento de produtos e processos. Além disso, as alterações nas fontes de insumos usados na produção ou o surgimento de uma nova tecnologia geraram desequilíbrios técnicos e influenciaram as condições técnicas nas etapas de projeto e melhoria das máquinas-ferramenta.

A principal base tecnológica dos Sistemas Setoriais emergentes é intensiva em informação. Entretanto destaca-se a combinação de conhecimentos de base mecânica, elétrica e de tecnologia da informação que são utilizados no desenvolvimento e melhorias das máquinas-ferramenta nos Sistemas Setoriais mais tradicionais.

Os Sistemas Setoriais têm apresentado relações de troca relativamente mais abertas entre produtores, usuários e instituições dos Sistemas Setoriais.

De maneira geral, as empresas de máquinas-ferramenta apresentam parcerias e alianças com clientes e instituições de pesquisa, como forma de promover o desenvolvimento de técnicos e sua inserção em outros mercados. Além disso, os agentes também têm desenvolvido redes e alianças mais formalizadas voltadas para a inovação (Wengel; Shapira, 2001).

Nas últimas décadas, as empresas de máquinas têm apresentado diferentes estratégias de especialização ou diversificação de produtos. Uma das justificativas para esse comportamento é que a interdependência de conhecimentos e as mudanças nas fontes de insumos podem gerar novas condições de oportunidade ou o abandono da trajetória presente.

As características da base de conhecimento no interior das empresas e dos segmentos de máquinas também têm apresentado algumas transformações.

O conhecimento interno as empresas dos Sistemas Setoriais de máquinas-ferramenta pode ser classificado pelo caráter tácito, por conta das especificidades dos conhecimentos acumulados ao longo do tempo. Entretanto, nos últimos anos os conhecimentos apresentaram também caráter mais codificado, como resultado da intensificação de esforços visando o aprendizado e a difusão de tecnologias. Vale lembrar que alguns modelos de máquinas podem ser fabricados em módulos, o que facilita a troca de informações e a especialização interna às empresas. 
O quadro 4.7 resume os elementos que caracterizam os Sistemas Setoriais de Inovação do setor de máquinas-ferramenta da Itália, Alemanha, EUA e Japão (Wengel \& Shapira, 2001):

\begin{tabular}{|c|c|c|}
\hline Elementos & Tradicional & Emergentes \\
\hline Forma de ligação externa & Limitada, estável & Aberta, flexível \\
\hline Escopo geográfico & Regional -> nacional & Regional -> internacional \\
\hline Base tecnológica & Mecânica & Intensiva em informação \\
\hline Desenvolvimento de produto & Incremental & Incremental -> sistemático \\
\hline Relações de troca & Produtores ligados com usuários & $\begin{array}{c}\text { Parcerias de produtores, usuários, } \\
\text { centros de pesquisa }\end{array}$ \\
\hline Conhecimento-base & Tácito & Tácito e codificado \\
\hline Treinamento & Variado & Variado -> interno e externo \\
\hline Forma Corporate & Individual, família & $\begin{array}{c}\text { Individual -> grupos corporativos } \\
\text { (limitada a multinacional) }\end{array}$ \\
\hline Organização de trabalho & Colaboração interna informal & $\begin{array}{c}\text { Cooperação externa e } \\
\text { formalizada }\end{array}$ \\
\hline Entrantes & Moderada barreira à entrada & Alta barreira à entrada inovação \\
\hline Demanda & Cíclica & Cíclica \\
\hline Política & Setorial nacional & $\begin{array}{l}\text { Regional - nacional - Européia } \\
\text { política de inovação genérica }\end{array}$ \\
\hline
\end{tabular}

Fonte: Wengel; Shapira (2001), p. 36 (tradução).

Quadro 4.7 - Características tradicionais e emergentes do Sistema de inovação no setor de máquinas-ferramenta

O ambiente do setor de máquinas-ferramenta apresenta um perfil de desenvolvimento técnico distinto entre os segmentos através dos países. Em países como a Alemanha, Itália, EUA e Japão as inovações são obtidas a partir de melhorias nas características técnicas de máquinas individuais (Wengel \& Shapira, 2001).

As inovações de processo são provenientes de outras áreas de conhecimento e outros ramos industriais, como a engenharia elétrica e de materiais. Esse aspecto é um dos principais diferenciais da indústria de máquinas-ferramenta daqueles países, relativamente aos países de industrialização recente.

De maneira geral, os vínculos estabelecidos entre diferentes áreas de conhecimento e diferentes atores (empresas, fornecedores, usuários e institutos de pesquisa) possibilitam o aprendizado de informações e de novas aplicações. Esses conhecimentos gerados e absorvidos, por sua vez, são 
internalizados junto às competências técnicas ao nível das empresas e do sistema econômico nacional.

As condições para o desenvolvimento técnico e as melhorias das máquinas são muito diferentes entre aqueles países. E esse fator moldou a dinâmica tecnológica e seu potencial para desenvolvimento no futuro.

Um dos fatores que influenciam as condições para a mudança técnica é o escopo geográfico dos Sistemas Setoriais de inovação de máquinasferramenta.

Na Itália e Alemanha, por exemplo, as empresas estão organizadas em aglomerações regionais típicas, que concentram empresas e instituições de todas as etapas de produção de máquinas numa mesma localidade.

A proximidade geográfica entre fabricantes de máquinas e outras etapas da cadeia contribuiu de maneira decisiva para o desenvolvimento industrial e tecnológico das empresas ao longo das décadas.

Em grande medida, a localização de empresas e instituições em uma mesma área geográfica pode facilitar as interações entre esses agentes, sejam usuários, fornecedores e instituições. A partir das interações estabelecidas entre empresa de diferentes etapas produtivas, verifica-se maior fluxo de informações visando à resolução de problemas técnicos, o desenvolvimento das atividades produtivas e a prestação de serviços.

Desse modo, nos países em que as atividades produtivas e demais etapas estão concentradas num mesmo espaço geográfico, verificam-se maiores condições para melhorias incrementais e o processo inovativo.

O Sistema Setorial de Inovação de máquinas-ferramenta da Itália é representativo da relevância da proximidade geográfica para 0 desenvolvimento do setor de máquinas.

As empresas de máquinas-ferramenta da Itália estão organizadas em Distritos Industriais localizados em quatro regiões do nordeste da Itália (Lombardia, Piemonte, Emilia-Romagna e Veneto).

Os Distritos Industriais italianos podem ser caracterizados pela presença de uma grande quantidade de empresas de pequeno porte que são altamente especializadas em adaptar e customizar máquinas.

Além disso, o setor de máquinas-ferramenta da Itália possui poucas grandes empresas que apresentam alto grau de diversificação da produção e 
que estão focando na fabricação de máquinas mais sofisticadas tecnologicamente (Wengel \& Shapira, 2001).

O desempenho do Sistema Setorial de Inovação de máquinasferramenta da Itália foi influenciado, principalmente, pela atuação de empresas de várias etapas e de atividades correlatas localizadas na mesma região.

As empresas italianas de máquinas-ferramenta são reconhecidas pelo projeto e desenvolvimento de produtos destinados a demandas específicas do mercado interno (e externo).

Grande parte dessas empresas desenvolve suas próprias atividades de projeto, componente mecânicos e testes in house. Outro aspecto importante é que essas empresas preferem comprar componentes eletrônicos de seus fornecedores ao invés de desenvolver.

Os serviços pós-venda oferecidos pelas empresas italianas assumem papel importante para a fidelização do mercado. Além disso, a interação e a troca de informações entre as áreas de venda, engenharia e os usuários das máquinas são importante mecanismo utilizado para o desenvolvimento e melhorias de produtos.

A presença de instituições e associações que surgiram para atender às necessidades específicas na produção das máquinas no interior do Sistema Setorial de Inovação italiano. Entretanto, a contribuição institucional está direcionada mais para o apoio financeiro e inserção no comércio internacional do setor, e menos ao desenvolvimento de ferramentas e técnicas particulares.

Por conta desses fatores, as empresas do Distrito Industrial italiano podem ser consideradas os principais atores responsáveis pela dinâmica tecnológica do Sistema Setorial de Inovação de máquinas-ferramenta da Itália.

A partir da década de 1990, os Distritos Industriais Italianos passaram por importantes transformações em seu ambiente institucional.

O governo italiano estabeleceu medidas voltadas às pequenas empresas, com o objetivo de incentivar o desenvolvimento de competências, a flexibilidade produtiva e a customização de produtos.

Entretanto, somente as empresas de grande porte dispunham de condições de acesso a linhas de financiamento para a aquisição e desenvolvimento de tecnologias de automação. 
Outro aspecto que caracteriza a evolução recente do Sistema Setorial de Inovação de máquinas-ferramenta da Itália é a redução do número de pequenas empresas e o aumento de grandes empresas que dominam a rede de relações no interior do Distrito. Além disso, destaca-se o aumento do número de empresas com orientação exportadora.

Nos últimos anos, o aumento do número de empresas com orientação exportadora tem contribuído para o desenvolvimento do Sistema Setorial de Inovação de três maneiras:

- Ampliação do leque de conhecimentos provenientes do ambiente externo ao Distrito;

- Melhoria da qualidade do conhecimento ao nível das empresas e segmentos industriais de máquina.

- Influência sobre o processo de aprendizado e difusão de tecnologias dos Distritos Industriais.

A concorrência com fabricantes de máquinas-ferramenta de outros países também tem modificado as características do sistema italiano e a estrutura produtiva dos distritos industriais de máquinas-ferramenta (Wengel; Shapira, 2001).

Nesse cenário, as vantagens decorrentes da localização geográfica se tornam menos importantes para o desempenho do Sistema Setorial de Inovação de máquinas-ferramenta da Itália. Além disso, há uma tendência para desempenho baseado em outros fatores competitivos como capacidade inovativa, flexibilidade para desenvolver melhorias e o preço dos produtos.

O Sistema Setorial de Inovação de máquinas-ferramenta da Alemanha apresenta duas características em comum com o Sistema Setorial de máquinas da Itália.

Em primeiro lugar, o setor também é formado por empresas de pequeno e médio porte. Entretanto, destaca-se a presença de empresas organizadas em grandes grupos de propriedade familiar e que apresentam estruturas de negócios mais diversificadas e forte profissionalização (Wengel \& Shapira, 2001).

Em segundo lugar, as empresas de máquinas da Alemanha também estão concentradas geograficamente em clusters industriais. As principais regiões com produção de máquinas-ferramenta estao localizadas nos estados 
federativos de Baden-Wuttemberg, Renânia do Norte-Vestfália e Bavaria (Buenstorf; Guenther, 2010).

A origem da indústria na Alemanha data de meados do século $X I X$, mas foi somente a partir do século XX que o setor se tornou competidor dos EUA, líder na produção mundial de máquinas (Buenstorf \& Guenther, 2010).

No período entre as décadas de 50 e 70, o desenvolvimento industrial das máquinas-ferramenta alemã foi acentuado pela demanda da indústria manufatureira européia (Buenstorf \& Guenther, 2010).

A partir dos anos 80, o governo alemão induziu o desenvolvimento de tecnologia do setor de máquina-ferramenta.

Uma das medidas adotadas nesse período foi o apoio a pesquisa e desenvolvimento sobre sistemas de produção flexível, com o objetivo de promover o desenvolvimento de tecnologias de produção. Posteriormente, os programas estavam direcionados, principalmente, para a ampliação de competências e a difusão de tecnologias CAD/CAM/CIM na indústria (Wengel; Shapira, 2001).

De maneira geral, dois fatores exerceram papel decisivo para o desenvolvimento do Sistema Setor de Inovação de máquinas-ferramenta da Alemanha.

O primeiro fator refere-se às interações usuário-produtor que viabilizaram a incorporação e desenvolvimento de conhecimentos tecnológicos por fabricantes de máquinas.

Além disso, os engenheiros das empresas se tornavam sócios naturais das empresas usuárias (Wengel \& Shapira, 2001), o que acelerou a velocidade para a realização de melhorias, a resolução de problemas técnicos e a especialização do setor.

Até a década de 1990, essas interações eram realizadas de maneira fechada e com a participação de engenheiros e técnicos especializados na produção de máquinas.

Wengel \& Shapira (2001) afirmam que as relações usuário-produtor apresentaram interações mais abertas e baixo grau de confiança entre fabricantes de máquinas e seus clientes. 
O segundo fator para explicar o desenvolvimento do Sistema Setorial de Inovação de máquinas da Alemanha refere-se às características do conhecimento no interior das empresas.

As estratégias inovativas das empresas alemãs estão concentradas, principalmente, na área de projeto e desenvolvimento. Além disso, as empresas direcionaram esforços para a criação de competências e o acúmulo de conhecimentos nos ramos de engenharia mecânica e engenharia elétrica.

O desenvolvimento e as melhorias do conhecimento ao nível da firma foram viabilizados, principalmente, a partir dos esforços orientados para a qualificação profissional; e a aquisição de conhecimento externo, por meio de cooperação em P\&D, inclusive com outros setores industriais. Nesse cenário, a participação de instituições e do Estado foi fundamental para fomentar e apoiar a mudança técnica da indústria de máquinas da Alemanha.

A partir dessas informações é possível notar que o desenvolvimento do Sistema Setorial de Inovação de máquinas-ferramenta da Itália e Alemanha apresenta algumas características específicas decorrentes da formação histórica do setor naqueles países.

Nesses países, a proximidade geográfica atuou como impulso inicial para o desenvolvimento do setor. As políticas públicas e, principalmente, a atuação empreendedora de empresas de várias etapas também contribuíram de maneira decisiva para o desenvolvimento técnico do setor. Além disso, outros fatores econômicos e elementos do Sistema Setorial de Inovação empresas de várias etapas, instituições e suas interações - exerceram papel importante sobre a dinâmica de desenvolvimento industrial e tecnológico das empresas de máquinas-ferramenta através dos países.

Desde a década de 1960, as condições para a inovação no setor de máquinas-ferramenta têm mudado significativamente com o surgimento de arranjos de inovação menos estáveis.

Ao longo das décadas, o surgimento de novas técnicas ou alterações nas propriedades dos insumos utilizados nas máquinas impôs novos limites e novas escolhas técnicas às empresas de máquinas-ferramenta. Neste ambiente, os países não apresentam as mesmas condições para a realização da mudança técnica interna e desenvolvimento industrial. 
O caráter locacional, por exemplo, não é tão significativo para o desempenho inovativo e a mudança técnica no Sistema Setorial de Inovação de máquinas-ferramenta em países como EUA e Japão.

O desenvolvimento das máquinas-ferramenta dos EUA e Japão foram influenciados, principalmente, pela utilização de tecnologias da microeletrônica.

A tecnologia de controle numérico computadorizado é formada por três componentes principais: unidade de controle, sistema de acionamento e a máquina-ferramenta adequada (Mazzoleni, 1997, p. 409):

"o primeiro lê as informações numéricas sobre a peça de metal a ser usinada e armazenada em uma fita, e traduz em comandos que ativam 0 servomecanismo do sistema de acionamento. Esses são conectados por meio mecânico para as partes móveis da máquina, geralmente do eixo da ferramenta e na mesa de trabalho" (tradução)

Nos anos 1960, havia duas trajetórias para a configuração de controle numérico nas máquinas-ferramenta: sistemas open-loop (circuito aberto) e sistemas closed-loop (circuito fechado).

O sistema de controle closed-loop pode ser caracterizado pela presença de feedback que possibilitam a produção flexível de máquinas com poucas especificações e a baixos custos.

Em uma configuração closed-loop, os elementos mecânicos, elétricos ou ópticos detectam o movimento real das peças de máquina e enviam a informação para a unidade de controle. Esta, por sua vez, compara a posição real das peças com o que foi gravado na fita. Detectada uma diferença, a unidade de controle envia os sinais para o servomecanismo que controla 0 movimento das peças da máquina-ferramenta (Mazzoleni, 1997, p. 409)

$\mathrm{Na}$ configuração open-loop não há esse feedback de informações à unidade de controle. Desse modo, a precisão das operações de usinagem dependerá exclusivamente da precisão do sistema de acionamento (Mazzoleni, 1997, p. 409-10), e os custos de produção são mais elevados em relação aos sistemas closed-loop.

Os eventos que possibilitaram o desenvolvimento e a evolução das máquinas de controle numérico foram influenciados por condições da demanda e por divergências na forma como o projeto de produto era realizado. $O$ 
Sistema Setorial de máquinas-ferramenta dos EUA e Japão são os casos mais emblemáticos dessa situação.

O Sistema Setorial de Inovação de máquinas-ferramenta dos EUA é formado por elevado número de pequenas empresas, que são especializadas na produção de máquina de acordo com especificações dos clientes; e por empresas de grande porte, responsáveis pela produção de máquinas destinadas principalmente à indústria automobilística.

A estrutura produtiva das empresas americanas está orientada, principalmente, para o desenvolvimento de processos. Esse fator pode ser atribuído às características da trajetória tecnológica do setor nas últimas décadas.

No início do desenvolvimento da indústria de máquinas, as empresas americanas contavam com a participação da área de engenharia e com a interação estabelecida com usuários de outros setores industriais para o projeto ou para melhoria das máquinas. Além disso, a demanda apresentou forte incentivo para o desenvolvimento técnico do setor.

Nesse cenário, o Sistema Setorial de Inovação de máquinas-ferramenta dos EUA assumiu a liderança no desenvolvimento tecnológico de produtos e processos nos ramos de máquinas.

A partir do século $X X$, a produção em larga escala da indústria automobilística demandava elevado volume de máquinas de várias finalidades e a contínua realização de melhorias nas competências incorporadas a essas máquinas (Wengel \& Shapira, 2001, p. 31).

Esse aspecto poderia influenciar a difusão dos conhecimentos de microeletrônica para outros setores e o desempenho industrial do ramo de máquinas-ferramenta dos EUA. Entretanto, as empresas de máquinasferramenta dos EUA apresentaram cenário distinto para o processo de incorporação de tecnologias de automação nas máquinas.

No período entre os anos 50-70, o envolvimento da demanda do setor militar dos EUA assumiu papel decisivo para o desenvolvimento de tecnologias de automação e a difusão de tecnologias de controle numérico computadorizado (Mazzoleni, 1997).

Os projetos desenvolvidos pelo MIT ainda nas décadas de 1950-60, para os melhoramentos da tecnologia de automação recebiam financiamento da 
Força Área. A demanda daquele setor moldou as escolhas visando o desenvolvimento de sistemas de controle numérico (open-loop) com precisão cada vez maior para atender as necessidades da Força Aérea americana.

Algumas empresas americanas apresentavam esforços para adaptar e incorporar técnicas de comando numérico computadorizado (inicialmente para aplicação na Força Aérea) à produção de máquinas (Mazzoleni, 1997). Mas para grande parte das empresas de máquinas de pequeno porte, a incorporação das novas tecnologias era incompatível com as exigências por produção customizada de pequenos lotes. Além disso, os custos da inserção dessas técnicas nas etapas de produção eram elevados, o que frequentemente, inviabilizavam o negócio.

As características da estrutura industrial americana também dificultaram a difusão inicial das tecnologias de automação (desenvolvidas naquele país) entre os fabricantes de máquinas. O desenvolvimento das máquinas de controle numérico também foi influenciado por dificuldades técnicas na etapa de projeto de produto.

O primeiro protótipo do sistema open-loop data de 1957, como resultado de uma nova aplicação da tecnologia 'stepping motor' inventada nos anos 30 . Entretanto, as melhorias realizadas no stepping motor desde aquela época foram muito modestas.

No período entre os anos de 1960 e 1970, o sistema open-loop apresentava limitações técnicas que dificultavam sua difusão na estrutura industrial americana e a sua utilização nas máquinas-ferramenta.

Uma dessas limitações refere-se às características dos servomotores motores que poderiam ser operados mais precisamente por sinais digitais enviados pelas unidades de controle ou pela transformação adequada desses mecanismos (Mazzoleni, 1997, p. 411).

Os motores desenvolvidos no mercado americano não reuniam os prérequisitos necessários para operar o sistema open-loop. Por esse motivo, o protótipo da máquina não foi mantido nas tentativas de comercializar CNC com sistema open-loop.

A percepção dos fabricantes de máquinas sobre os problemas e as oportunidades colocadas pela tecnologia de comando numérico foram relevantes para a decisão de adotar (ou não) aquelas tecnologias. 
De maneira geral, as alternativas de automação desenvolvidas nos EUA geralmente eram descartadas, seja por conta dos elevados custos de produção ou porque não viabilizavam a precisão nas operações das máquinas. Mas outros fatores também atuavam como incentivo ou limitação ao desenvolvimento daquelas tecnologias.

De um lado, os fabricantes de máquinas não reuniam competências em eletrônica e sistemas, necessários para os melhoramentos das tecnologias de controle numérico computadorizado. De outro lado, a percepção dos usuários apontava para as dificuldades decorrentes da complexidade e elevado custo das máquinas de comando numérico. Esse conjunto de fatores dificultou a difusão inicial das tecnologias nos EUA no setor de máquinas-ferramenta.

A utilização das tecnologias de controle numérico nas máquinasferramenta dos EUA foi viabilizada, principalmente, após a inserção de empresas fabricantes de controle eletrônico que desenvolveram melhorias voltadas à adaptação daquelas tecnologias para as máquinas.

Entretanto, os fabricantes de máquinas apresentavam poucas interações com usuários e fornecedores das unidades de controle eletrônico. Além disso, o tempo decorrido entre a descoberta e a difusão das tecnologias no mercado americano era relativamente elevado.

Por conta desses fatores, os EUA sediaram o desenvolvimento inicial de técnicas de controle numérico em meados dos anos de 1960, mas não apresentaram difusão das tecnologias de automação entre fabricantes de máquinas. A combinação desses fatores também foi determinou a perda de posição dos EUA no mercado mundial de máquinas-ferramenta de controle numérico computadorizado na década de $1980^{33}$.

Nesse período, o Sistema Setorial de máquinas-ferramenta do Japão assumiu a liderança na produção mundial e na mudança técnica do setor de máquinas-ferramenta.

O Sistema Setorial de Inovação de máquinas-ferramenta do Japão pode ser caracterizado pela forte capacidade inovativa interna e dependência em relação às instituições públicas (Wengel \& Shapira, 2001).

\footnotetext{
${ }^{33}$ Outro aspecto que influenciava a escolha pela tecnologia de controle numérico era a necessidade de reorganização do processo de trabalho e a existência de problemas de comunicação entre o chão-defábrica e a área de programação (Mazzoleni, 1997, p. 414-15).
} 
O setor de máquinas-ferramenta do Japão é formado por elevado número de pequenas empresas e algumas de médio porte, que estão associadas a grandes grupos e exercem papel fundamental sobre a dinâmica tecnológica do setor.

As empresas japonesas são reconhecidas mundialmente pelo desenvolvimento e melhorias de tecnologias de produção com uso de informática. Essa característica pode ser atribuída a dois fatores.

Em primeiro lugar, as empresas desenvolvem competências in house (Wengel \& Shapira, 2001), a partir da introdução de novos conceitos de produção e inovações organizacionais que possibilitaram ganhos de produtividade para o setor e para outras indústrias. Em segundo lugar, as empresas de máquinas-ferramenta do Japão desenvolvem contratos fechados com seus principais clientes e participam de vários grupos industriais e projetos colaborativos.

Essa forma de atuação repercute, principalmente, no acúmulo de conhecimentos sobre tecnologias e aplicações que são internalizados pelas empresas e instituições envolvidos nos projetos colaborativos. Além disso, uma consequência importante daqueles contratos fechados para as empresas é o desenvolvimento de habilidades para reconhecer o potencial das trajetórias tecnológicas.

Algumas empresas japonesas também têm direcionado esforços para o desenvolvimento de empresas subsidiárias, que são direcionadas à produção de softwares utilizados nas máquinas-ferramenta.

O desempenho industrial e tecnológico do setor no Japão nas últimas décadas pode ser atribuído, principalmente, às escolhas entre trajetórias tecnológicas dentro do paradigma de controle numérico computadorizado.

No período entre 1965 e 1975, a indústria japonesa estava mais interessada em aplicações de controle numérico voltadas à produção flexível do que em tecnologias destinadas a aumentar a precisão das máquinas. Por esse motivo, o sistema closed-loop encontrou melhores condições para seu desenvolvimento no setor de máquinas-ferramenta no Japão.

Vale notar que no período inicial de desenvolvimento técnico do setor, as empresas japonesas concentram esforços na produção de tipos de máquinas- 
ferramenta relativamente simples e importavam máquinas mais sofisticadas de outros países.

Havia um intenso processo de transferência de conhecimentos através de acordos de licenciamento. Esse mecanismo, por sua vez, possibilitava a criação de competências em manufatura e o melhoramento de seus produtos, e estava direcionado para o atendimento da demanda local por equipamentos especializados.

A necessidade de ampliar as aplicações das tecnologias de produção flexíveis, desenvolvidas por empresas de pequeno e médio porte, foi fundamental para o desenvolvimento de inovações e o rápido aumento na escala de produção (Mazzoleni, 1997, p. 406).

Um diferencial em relação à dinâmica tecnológica do setor de máquinas dos EUA é participação de empresas japonesas individuais, que incorporaram conhecimentos sobre computadores confiáveis e ferramentas flexíveis numericamente controladas (CNC).

A empresa Fujitsu-Fanuc é o caso mais representativo dos mecanismos utilizados para a mudança técnica do setor de máquinas-ferramenta do Japão.

Em meados da década de 1960, o engenheiro Seiuemon Inaba estudou o projeto desenvolvido pelo MIT com o objetivo de replicar o sistema open-loop no Japão.

A empresa Fanuc acreditava que a necessidade de feedback tornava complicado o projeto e a fabricação do sistema. Além disso, aumentava o seu custo de produção, devido à necessidade de circuitos eletrônicos para 'fechar o ciclo' (Mazzoleni, 1997, p. 410-11).

Para a empresa Fanuc, uma maneira mais eficaz para promover 0 desenvolvimento do comando numérico era por meio de melhoramentos da tecnologia stepping motor, usada para operar máquinas de controle numérico na configuração open-loop $p^{34}$. Ao longo dos anos, as melhorias incrementais naquela tecnologia stepping motor e o desenvolvimento de variantes tornaram o sistema open-loop tecnicamente adequado para um conjunto de operações de usinagem nas máquinas japonesas.

\footnotetext{
${ }^{34}$ A empresa Fanuc abandou a configuração open-loop em meados dos anos 70, antes dos esforços de venda nos EUA e outros mercados. O desempenho da empresa não pode ser atrelado exclusivamente ao projeto de produto open loop. Mas esse foi um elemento importante para explicar sua posição no mercado mundial de máquinas (Mazzoleni, 1997, p. 412).
} 
Desse modo, a atuação da Fujitsu foi fundamental para a construção de competências na fabricação de máquinas em grande volume, o que reduziria $o$ seu preço de venda (Wengel \& Shapira, 2001).

Vale notar que essas melhorias foram perseguidas por empresas dos EUA, Japão e Europa, mas um conjunto de fatores contribuiu para o estabelecimento da trajetória de controle numérico no mercado japonês.

Em primeiro lugar, as mudanças institucionais promovidas pelo Estado japonês possibilitaram a incorporação de tecnologias e o desenvolvimento e difusão de técnicas de produto e processo na indústria.

Em segundo lugar, destaca-se a percepção do produtor de máquinas japonesas em relação ao potencial oferecido por essas tecnologias de controle numérico. Após a fase de identificação de oportunidade, as empresas japonesas destinaram esforços para tornar as inovações viáveis economicamente.

Nesse sentido, a participação dos usuários e fornecedores de máquinas também acentuou a dinâmica técnica da indústria. De maneira geral, os usuários contribuíram para o desenvolvimento inovativo das máquinas de três maneiras (Lee, 1996):

a) Fluxo de investimentos direcionados à resolução de problemas decorrentes da expansão de capacidade ou aumento da produtividade;

b) Entrada tecnológica dos usuários no processo de fabricação de máquinas;

c) Entrada comercial dos usuários, visando os ganhos econômicos de suas inovações.

Desse modo, aqueles atores do Sistema Setorial de Inovação de máquinas-ferramenta do Japão conduziam a mudança técnica da indústria de máquinas através de diferentes percepções sobre a tecnologia de controle numérico, que eram ajustadas à escolha estratégica das firmas produtoras e ao comportamento dos usuários.

A direção e velocidade da mudança das tecnologias de controle numérico foram acentuadas por características específicas dos Sistemas Setoriais de máquinas-ferramenta de cada país. 
As características específicas da demanda interna e do ambiente econômico e industrial de cada país forneceram as condições iniciais para o desenvolvimento das tecnologias nas máquinas-ferramenta. No longo prazo, esses fatores repercutiram na criação de novos produtos e, principalmente, em diferentes condições para a criação, difusão e aprendizado de tecnologias.

O processo de aprendizado cumulativo, por sua vez, influenciou as escolhas tecnológicas dos fornecedores e usuários das máquinas em diferentes caminhos. Além disso, as escolhas ocorriam em um tempo diferente entre as etapas de produção, difusão e comercialização das novas técnicas naqueles países.

A partir da década de 1990, a oscilação da demanda (Wengel \& Shapira, 2001, p. 7) e a inserção de outros países com produção de máquinas refletiram em novo reposicionamento das empresas do setor de máquinas-ferramenta. Outro indicador que ilustra essa nova situação é a queda do número de empresas e de funcionários no segmento de máquinas-ferramenta daqueles países.

A pressão por mudança tecnológica e o contexto institucional da indústria de máquinas-ferramenta com diferentes escopos e ações determinaram a consolidação de diferentes tipos nacionais de mudanças da indústria de máquinas através dos países (Wengel \& Shapira, 2001, p. 8).

Nos últimos anos, o Sistema Setorial de Inovação tem fomentado esforços em P\&D e mudanças na dinâmica da inovação organizacional e de processo. Essas características do processo de inovação na indústria de máquinas-ferramenta são apresentadas no quadro 4.8 . 


\begin{tabular}{|c|l|l|}
\hline $\begin{array}{c}\text { Foco da } \\
\text { inovação }\end{array}$ & \multicolumn{1}{|c|}{$\begin{array}{c}\text { Técnica } \\
\text { (harder) }\end{array}$} & \multicolumn{1}{c|}{$\begin{array}{c}\text { Organizacional } \\
\text { (softer) }\end{array}$} \\
\hline Produto & $\begin{array}{l}\text { 1. Novos produtos } \\
\text { - Centros de usinagem, Tecnologias } \\
\text { de corte, software. }\end{array}$ & $\begin{array}{l}\text { 2. Serviços de adicionar valor } \\
\text { - Financiamento, treinamento, etc. }\end{array}$ \\
\hline Processo & $\begin{array}{l}\text { 3. Tecnologia de produção } \\
\text { - Melhoria tecnológicas no processo } \\
\text { de produção, ferramentas e uso de } \\
\text { informática. }\end{array}$ & $\begin{array}{l}\text { 4. Novos conceitos de produção } \\
\text { Administração da cadeia de valor. }\end{array}$ \\
\hline
\end{tabular}

Fonte: Wengel \& Shapira (2001), p. 2 (tradução)

Quadro 4.8 - Spectro da inovação na indústria de máquinas-ferramenta da Alemanha, Itália, Japão e EUA

Diante desse cenário, nota-se uma importante combinação de elementos do Sistema Setorial de Inovação - empresas de várias etapas, instituições e suas interações - no desenvolvimento e melhorias das tecnologias. O quadro 4.9 apresenta os atores e resume as características do desenvolvimento do setor de máquinas-ferramenta, considerando a discussão realizada nos capítulos 3 e 4 da tese.

\begin{tabular}{|c|c|c|c|}
\hline Período & $\begin{array}{l}\text { Principais } \\
\text { países com } \\
\text { produção de } \\
\text { máquinas- } \\
\text { ferramenta }\end{array}$ & Principais atores & $\begin{array}{c}\text { Principais características do } \\
\text { conhecimento tecnológico do } \\
\text { setor }\end{array}$ \\
\hline $\begin{array}{l}\text { Início do } \\
\text { século XIX }\end{array}$ & $\begin{array}{l}\text { Inglaterra e } \\
\text { EUA }\end{array}$ & $\begin{array}{l}\text { - Empresas com produção de } \\
\text { máquinas; } \\
\text { - Usuários das máquinas; }\end{array}$ & $\begin{array}{l}\text { - Aprendizado interno (empresas } \\
\text { de máquinas), durante o processo } \\
\text { de produção. }\end{array}$ \\
\hline $\begin{array}{l}\text { A partir de } \\
\text { meados do } \\
\text { século } X I X\end{array}$ & EUA e Japão & $\begin{array}{l}\text { - Usuários das máquinas } \\
\text { - Participação do Estado e Institutos } \\
\text { de pesquisa; } \\
\text { - Interação com outros ramos } \\
\text { (fornecedores) e outras áreas da } \\
\text { ciência; }\end{array}$ & $\begin{array}{l}\text { - Aprendizado interno (empresas } \\
\text { de máquinas), durante o processo } \\
\text { de produção; } \\
\text { - Conhecimento empírico e } \\
\text { científico (institutos). }\end{array}$ \\
\hline $\begin{array}{l}\text { A partir do } \\
\text { século XX }\end{array}$ & $\begin{array}{l}\text { EUA, Japão, } \\
\text { Itália e } \\
\text { Alemanha. }\end{array}$ & $\begin{array}{l}\text { - Usuários das máquinas; } \\
\text { - Participação do Estado; } \\
\text { - Institutos de pesquisa assumem } \\
\text { papel mais importante na fronteira } \\
\text { tecnológica; } \\
\text { - Empresas individuais e } \\
\text { conglomerados (Japão); } \\
\text { - Participação de fornecedores } \\
\text { (eletrônicos) na difusão e } \\
\text { incorporação de novos } \\
\text { conhecimentos. }\end{array}$ & $\begin{array}{l}\text { - Conhecimento científico também } \\
\text { assume papel importante para o } \\
\text { desenvolvimento e atualização } \\
\text { tecnológica do setor; } \\
\text { - Forte integração entre diferentes } \\
\text { áreas de conhecimento } \\
\text { (mecânica, eletrônica, física, } \\
\text { engenharia de produção, } \\
\text { engenharia de materiais). }\end{array}$ \\
\hline
\end{tabular}

Fonte: Elaboração própria, com base em informações da revisão bibliográfica sobre Sistema Setorial de Inovação.

Quadro 4.9 - Principais atores e características do desenvolvimento do setor de máquinasferramenta - países selecionados 
A presença de um Sistema Setorial de Inovação de máquinasferramenta consolidado é um dos principais fatores para explicar o atual desempenho industrial e tecnológico do Japão e Alemanha.

Os Sistemas Setoriais de Inovação de máquinas-ferramenta mudaram seus limites em resposta às mudanças competitivas e tecnológicas. Além disso, esses Sistemas se adaptaram ao regime tecnológico do setor e impõem condições específicas para as atividades inovativas desenvolvidas no interior das empresas. O próximo capítulo apresenta o panorama do setor de máquinas-ferramenta do Brasil e discute as características de sua dinâmica industrial e tecnológica considerando os conceitos de regime tecnológico e Sistema de Inovação de máquinas-ferramenta. 


\section{Capítulo 5 - O setor de máquinas-ferramenta no Brasil}

Esse capítulo apresenta uma discussão sobre a competitividade e a dinâmica tecnológica do setor de máquinas-ferramenta do Brasil.

A primeira seção apresenta um breve panorama sobre o setor nas últimas décadas do século passado, enfatizando o desenvolvimento de tecnologias.

A segunda seção discute dados recentes sobre a estrutura industrial considerando número e localização das unidades produtivas, perfil das empresas, o emprego do setor, a produção nacional e a participação do setor de máquinas-ferramenta no comércio internacional.

A terceira seção as características da dinâmica competitiva e tecnológica do setor de máquinas-ferramenta do Brasil no período recente

\subsection{Panorama sobre o setor de máquinas-ferramenta no Brasil}

A indústria de bens de capital brasileira apresenta importante papel para o desenvolvimento econômico e tecnológico nacional.

Em primeiro lugar, a produção interna de máquinas é importante para reduzir a restrição externa ao crescimento e melhorar a condição da Balança de Pagamentos. Essa característica pode ser justificada pelo fato de que a maior produção nacional de máquinas possibilita o controle da propensão marginal a importar, mesmo nas condições em que há aumento da taxa de investimento da economia (Alem \& Pessoa, 2005, p. 77).

Em segundo lugar, a indústria pode contribuir para o desempenho macroeconômico nacional por conta de seu papel na geração de emprego e renda no mercado interno.

Em terceiro lugar, a indústria de máquinas também é responsável por ganhos de produtividade e de escala na estrutura produtiva e pela difusão de mudança técnica intra-setorial e para outros ramos industriais no nível nacional (Alem; Pessoa, 2005, p. 77). 
As atividades dos setores de máquinas estão direcionadas para 0 atendimento da demanda de outros setores, interligando a dinâmica de ramos industriais, da agropecuária e de serviços.

Nesse sentido, os esforços voltados ao desenvolvimento e modificações das máquinas podem contribuir para o desempenho produtivo e tecnológico das empresas daqueles ramos industriais.

Por outro lado, os fabricantes de máquinas também são consumidores dos bens que ele próprio produz (Avellar; Strachman, 2008, p. 239) e dependem de interações com outros setores para o desenvolvimento e melhorias de suas máquinas.

Apesar dos fatores positivos atribuídos à presença de uma indústria de bens de capital nacional, o setor de máquinas e em especial o ramo de máquinas-ferramenta do Brasil apresentam grande instabilidade no desenvolvimento de sua estrutura industrial, produtiva e tecnológica.

Além disso, na comparação entre o desempenho do setor de máquinasferramenta do Brasil e de outros países, o setor nacional também apresenta posição relativamente mais difícil.

O setor de máquinas-ferramenta do Brasil começou a ganhar representatividade em termos de produção e número de empresas a partir da década de 1970, em virtude do crescimento da demanda da indústria automobilística por máquinas. De maneira geral, as estratégias de investimento em produção, modernização ou ampliação da capacidade produtiva por empresas de máquinas estão condicionadas à perspectiva de aumento da demanda no mercado nacional, seja da indústria automobilística ou de outros ramos industriais.

Nos períodos em que a indústria de transformação como um todo apresenta baixa perspectiva em relação à demanda, as empresas reduzem seus investimentos na aquisição ou modernização de seu parque produtivo, o que reflete em redução do nível de investimentos em máquinas.

Nos períodos em que a indústria apresenta alta perspectiva em relação à demanda, por sua vez, as empresas tendem a ampliar seus investimentos na ampliação de máquinas ou modernização de seu parque industrial. 
Em especial, as variações da demanda da indústria automobilística repercutem no desempenho dos ramos de máquinas do Brasil, configurando uma característica estrutural da indústria nacional de máquinas-ferramenta.

Até meados dos anos 80, a estrutura produtiva do setor de máquinasferramenta era formada por três grupos de empresas:

a) empresas estrangeiras de grande porte, que fabricavam máquinasferramenta com maior complexidade tecnológica;

b) empresas nacionais de médio e grande porte, que produziam máquinas convencionais e máquina que incorporavam comando numérico de uso universal; e

c) empresas nacionais de micro e pequeno porte, que fabricavam máquinas com menor complexidade tecnológica (Vermulm, 1996).

As empresas nacionais e estrangeiras direcionavam seus modelos de máquinas-ferramenta, principalmente, para o atendimento do mercado interno e pouco para o mercado regional (América Latina) e internacional.

As empresas estrangeiras de grande porte que estabeleceram suas unidades no mercado interno comercializavam modelos de máquinas projetadas na unidade da matriz. Além disso, esses modelos de máquinas incorporavam tecnologias já conhecidas no mercado externo e que representavam novidade para o mercado brasileiro.

As empresas nacionais de máquinas, por sua vez, fabricavam e vendiam máquinas que incorporavam tecnologias mais simples, e que eram comercializadas no mercado interno. Considera-se que o direcionamento da produção de máquinas, principalmente, para o mercado interno influenciou a dinâmica produtiva e tecnológica do setor nacional naquele período.

O tamanho limitado do mercado interno de máquinas implicava em baixa escala de produção dos modelos de máquinas. Para lidar com essa situação, as empresas nacionais apresentavam estratégias de diversificação de suas linhas de produtos. Entretanto, ao ampliar a sua linha de produtos, as empresas apresentavam menores condições para gerar economia de escala tecnológica (Vermulm, 1996, p. 42).

Outro fator que influenciou o desenvolvimento do setor de máquinasferramenta até meados dos anos 80 foi a verticalização da produção, em especial, de peças e componentes usinados. De maneira geral, como as 
empresas precisavam se dedicar também à produção de lotes pequenos de peças e componente, essa característica restringia o desenvolvimento de tecnologias no setor de máquinas (Vermulm, 1996, 42).

Naquele período, as políticas macroeconômicas ${ }^{35}$ de cunho protecionista também conduziam a uma estrutura industrial com baixo incentivo ao desenvolvimento de tecnologias nacionais e presença de elevado conteúdo importado.

Isso porque o elevado conteúdo de máquinas importadas e que incorporavam tecnologias obsoletas refletia na baixa produtividade da estrutura industrial brasileira (Gomes et al, 1995, p. 57).

Um fator positivo para o desempenho do setor é que grande parte do consumo de máquinas era suprida pela oferta do mercado interno. Entretanto, o setor de máquinas-ferramenta apresentava baixo coeficiente de exportações relativamente ao setor de máquinas-ferramenta de outros países (Vermulm, 1996).

A literatura setorial destaca que as condições do mercado interno e a instabilidade no cenário econômico são alguns dos motivos que podem explicar o desenvolvimento tardio de tecnologias e a baixa eficiência produtiva das empresas de máquinas-ferramenta com unidades de produção instaladas no mercado interno.

Um aspecto importante é que para obter ganhos com a produção de máquinas baseadas em tecnologias defasadas, as empresas nacionais precisariam orientar suas vendas também para o mercado externo e ampliar a escala de produção (Sabbatini, 2009). Entretanto, o setor de máquinasferramenta atuava no mercado interno.

No início dos anos de 1980, o setor de máquinas-ferramenta nacional enfrentou uma queda da demanda por máquinas no mercado interno e externo, e essa condição influenciou uma revisão das estratégias tecnológicas das empresas. Naquele cenário, algumas empresas de máquinas-ferramenta de médio e grande porte, que já conheciam as tecnologias de comando numérico, investiram na incorporação daquelas tecnologias aos seus modelos de

\footnotetext{
${ }^{35} \mathrm{O}$ capítulo não discutirá os efeitos das condições macroeconômicas, como taxa de juros e câmbio; os efeitos das políticas de fomento e das políticas industriais sobre o desempenho do setor de máquinasferramenta.
} 
máquinas convencionais, visando à ampliação de suas vendas no mercado nacional e internacional.

A incorporação da eletrônica às máquinas representava uma nova trajetória tecnológica para os segmentos de máquinas e equipamentos. Entretanto, grande parte dos ramos industriais de máquinas do Brasil não apresentava as condições para se apropriar de conhecimentos e obter ganhos econômicos com a nova trajetória tecnológica.

Especialmente no segmento de máquinas-ferramenta, a elevada verticalização da produção influenciou o desenvolvimento industrial das empresas, mas a baixa escala produtiva dificultou a difusão das tecnologias de comando numérico neste setor.

A política macroeconômica adotada em meados dos anos 80 , visando à redução da inflação e da dívida pública, determinou o aumento da incerteza em relação ao desempenho econômico e a queda dos investimentos na economia (Vermulm, 1996, p 84).

A partir do final da década de 1980, a abertura da economia brasileira ao comércio internacional repercutiu na nova dinâmica industrial e tecnológica do setor de máquinas-ferramenta.

Algumas empresas de máquinas-ferramenta promoveram a otimização de suas unidades produtivas considerando as exigências da demanda no mercado interno e passaram a direcionar sua produção de máquinas também para o mercado externo.

Além disso, grande parte dessas empresas revisou suas estratégias de desenvolvimento industrial, considerando a necessidade de incorporar tecnologias de automação. Nesses casos, verifica-se a realização de parceiras entre empresas nacionais e estrangeiras como forma de promover 0 aprendizado de novas tecnologias.

Entretanto, ainda persistia o diferencial entre a estrutura das empresas de máquinas de origem nacional e estrangeira.

Os esforços das empresas nacionais visando o desenvolvimento de tecnologias eram tímidos ou nulos. De maneira geral, as empresas nacionais mantinham gastos médios com P\&D em relação ao faturamento em torno de $1,5 \%$ (Gomes, 1995, p. 57). 
Outro fator importante é que os ramos de máquinas-ferramenta apresentavam sérias restrições em termos de desempenho industrial e tecnológico nacional, e em relação ao desempenho do mesmo setor em outros países.

Após esse panorama sobre o desenvolvimento do setor de máquinasferramenta nas décadas de 1970 a 1990, as próximas seções irão analisar o desempenho do setor de máquinas-ferramenta do Brasil nos últimos anos desta década. 


\subsection{A dinâmica industrial e competitiva do segmento de máquinas- ferramenta}

A Classificação Nacional de Atividade Econômica (CNAE) realizada periodicamente pelo Instituto Brasileiro de Geografia e Estatísticas (IBGE) divide a indústria de bens de capital em quatro setores industriais de acordo com a finalidade principal das máquinas: a) Máquinas, aparelhos e materiais elétricos; b) Máquinas e equipamentos; c) Veículos automotores, reboques e carrocerias; e d) Outros equipamentos de transporte, exceto veículos automotores ${ }^{36}$.

Cada um desses quatro setores é subdividido em outros segmentos industriais. O setor de máquinas e equipamentos, por exemplo, abrange seis classes (ou segmentos) industriais, o que inclui o ramo de máquinasferramenta:

a) Motores, bombas, compressores e equipamentos de transmissão;

b) Fabricação de máquinas e equipamentos;

c) Máquinas e equipamentos de uso geral;

d) Tratores e máquinas e equipamentos para a agricultura e pecuária;

e) Máquinas-ferramenta;

f) Máquinas e equipamentos de uso na extração mineral e na construção;

g) Máquinas e equipamentos de uso industrial específico;

h) Veículos automotores, reboques e carrocerias;

i) Outros equipamentos de transporte, exceto veículos automotores.

A classe 'Fabricação de máquinas-ferramenta', por sua vez, é subdividida na subclasse 2840-2, que é o nível maior de desagregação e corresponde às máquinas-ferramenta propriamente ditas. O quadro 5.1 apresenta a lista de produtos incluídos na subclasse 2840-2 (Fabricação de máquinas-ferramenta).

\footnotetext{
${ }^{36}$ O Anexo A apresenta a Classificação nacional de atividade econômica (CNAE) para a indústria de bens de capital.
} 


\section{Descrição dos produtos incluídos na Classe Fabricação de máquinas-ferramenta}

- Acabadora de engrenagens;

- Acessórios para máquinas-ferramenta (mandris, porta-ferramentas, etc);

- Afiadeira de serras;

- Centros de Usinagem;

- Desbastadora para metais;

- Desempenadeira de madeira;

- Desengrossadeira para madeira;

- Dobradeiras e Viradeiras para metais;

- Esmerilhadeiras (ferramentas elétricas manuais);

- Esmerilhadora para metais, Elétrica manual;

- Fresadoras (Horizontais; Verticais; Universais);

- Furadeira (De Bancada; De coluna; Múltipla; Para a indústria de madeira; Para metais n.e; Radial);

- Furadeiras, lixadeiras, serras, politrizes e outras ferramentas manuais elétricas ou a ar comprimido;

- Laminadores para madeira;

- Lixadeiras (ferramentas elétrica manuais, para madeira, n.e.);

- Mandrilhadeira (Horizontal, Vertical, Múltipla, De coordenadas);

- Máquinas para aplainar, plainas-limadoras e máquinas para escatelar, inclusive de comando numérico;

- Máquinas para mandrilar, inclusive de comando numérico;

- Máquinas para serrar ou seccionar, inclusive de comando numérico;

- Máquinas para solda elétrica ou não, com ou sem capacidade para cortar metais;

- Máquina-ferramenta de comando numérico ou que integre várias fases do trabalho;

- Máquinas-ferramenta não elétricas;

- Máquinas-ferramenta para furar, escarear, fresar ou roscar, inclusive de comando numérico;

- Máquinas-ferramenta para indústria de borracha;

- Máquina-ferramenta para rebarbar, afiar, amolar, retificar, brunir, polir ou outros acabamentos, inclusive de comando numérico;

- Máquinas-ferramenta para serrarias;

- Máquinas-ferramenta para trabalhar quaisquer materiais por desbaste, inclusive de comando numérico;

- Máquinas-ferramenta, incluídas as prensas, para forjar ou estampar, inclusive de comando numérico;

- Motosserras;

- Peças e acessórios para ferramentas elétricas;

- Peças e acessórios para furadeiras industriais;

- Peças e acessórios para prensas industriais;

- Peças e acessórios para serras industriais;

- Peças e acessórios para tornos industriais;

- Peças para máquinas-ferramenta;

- Plainas combinadas para trabalhar madeira;

- Plainas para trabalhar metais;

- Politrizes e moto-esmeris;

- Prensas industriais para madeira ou metal;

- Retificadeira (horizontal, vertical, etc.);

- Rosqueadeiras;

- Serra (circular, combinada, de desdobro, de folhas múltiplas, de pêndulo, radial, etc) para indústria de madeira;

- Serras (de fita, de lamina, etc.) para trabalhar metais;

- Serras para metais, N.E (máquinas);

- Talhadeiras (Máquinas para madeira);

- Tesourões para cortar metais;

- Torno (Copiador; De puxar, Frontal ou de platô; Paralelo Universal; Tipicamente automático; Vertical; Revólver);

- Tornos para metais, inclusive de comando numérico;

- Tornos, inclusive de comando numérico;

- Tupias para trabalhar madeiras.

Fonte: Classificação Nacional de Atividade Econômica. Concla, IBGE (2012c). Disponível em: http://www.cnae.ibge.gov. br/pesquisa. asp? action=anterior\&intPage=2\&Pesquisa=2840-

Quadro 5.1 - Produtos incluídos na classe Fabricação de máquinas-ferramenta

Os quatro setores que compõem a indústria de bens de capital apresentam uma heterogeneidade de condições produtiva, tecnológica e 
concorrencial. E esses fatores, por sua vez, refletem em diferenças no desempenho dos indicadores intra-indústria ao longo do tempo.

Dentre os setores que compõem a indústria de bens de capital, o setor de máquinas e equipamentos é o que apresenta maior número de unidades locais. O gráfico 5.1 apresenta dados sobre o número de unidades locais da indústria de bens de capital, considerando a participação do setor de máquinas e equipamentos no período de 2007 a 2010.

Gráfico 5.1 - Total de unidades locais da indústria de bens de capital do Brasil - 2007 a 2010.

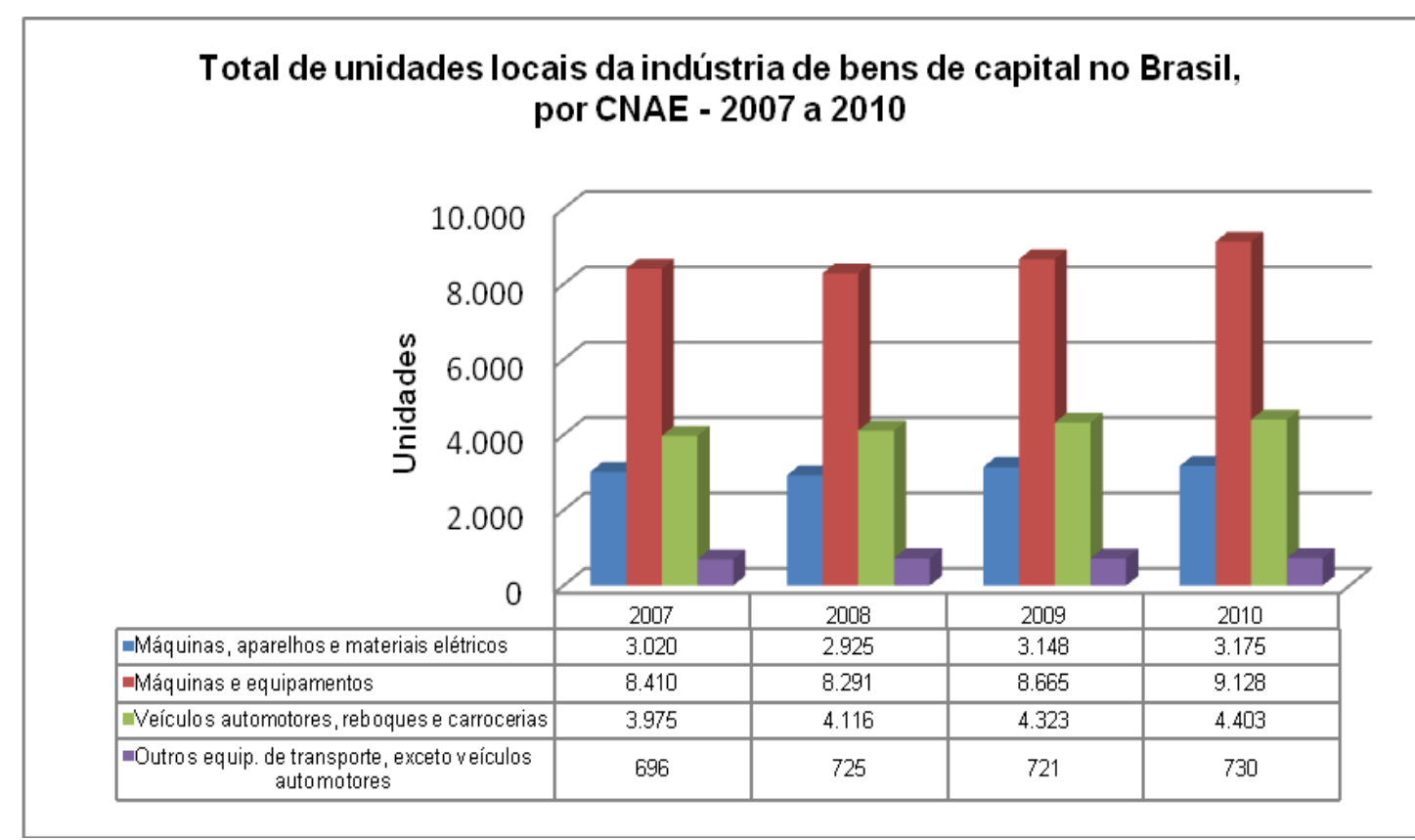

Fonte: IBGE (2012a) - Pesquisa Industrial Anual Empresa. Disponível em: http://www.sidra.ibge.gov.br/bda/tabela/protabl.asp?c=1848\&z=p\&0=16\&i=P

Unidades locais com 5 ou mais pessoas ocupadas, segundo as divisões e os grupos de atividades (CNAE 2.0)

De acordo com o gráfico 5.1, em 2010 a indústria de bens de capital apresentava 17.436 unidades locais, sendo que 9.128 (ou 52,4\%) eram unidades com produção para o setor de máquinas e equipamentos.

Outro setor em que as unidades locais apresentam participação importante no total da indústria é o setor de Veículos automotores, reboques e carrocerias, com 4.403 unidades locais ou $25,3 \%$ do total de unidades locais da indústria de bens de capital. Os dados sobre a participação do total de unidades locais por setores da indústria de bens de capital são apresentados na tabela 5.1 . 
Tabela 5.1 - Participação das unidades locais dos setores de máquinas no total da indústria de bens de capital do Brasil - 2007 a 2010.

\begin{tabular}{|l|c|c|c|c|}
\hline \multirow{2}{*}{\begin{tabular}{|l|l|} 
Segmentos da indústria de bens de capital \\
Máquinas, aparelhos e materiais elétricos.
\end{tabular}} & \multicolumn{3}{|c|}{$\begin{array}{l}\text { Participação das unidades locais no total de } \\
\text { unidades da indústria de bens de capital (\%) }\end{array}$} \\
\cline { 2 - 5 } & $\mathbf{2 0 0 7}$ & $\mathbf{2 0 0 8}$ & $\mathbf{2 0 0 9}$ & $\mathbf{2 0 1 0}$ \\
\hline Máquinas e equipamentos & 18,8 & 18,2 & 18,7 & 18,2 \\
\hline Veículos automotores, reboques e carrocerias. & 52,2 & 51,6 & 51,4 & 52,4 \\
\hline Outros equipamentos de transporte, exceto veículos automotores. & 24,7 & 25,6 & 25,6 & 25,3 \\
\hline
\end{tabular}

Fonte: IBGE (2012a). Pesquisa Industrial Anual Empresa.

Unidades locais com 5 ou mais pessoas ocupadas, segundo as divisões e os grupos de atividades (CNAE 2.0)

\section{A estrutura industrial do segmento de máquinas-ferramenta do}

Brasil pode ser analisada a partir de informações sobre número e localização das unidades locais de produção; dados sobre número e perfil dos funcionários empregados por empresas; dados de produção física e desempenho do segmento no comércio internacional de máquinas. O gráfico 5.2 apresenta o total de unidades locais do setor de máquinas e equipamentos e o do ramo de máquinas-ferramenta no período de 2007 a 2010.

Gráfico 5.2 - Unidades locais do setor de máquinas e do segmento de máquinas-ferramenta do Brasil - 2007 a 2010.

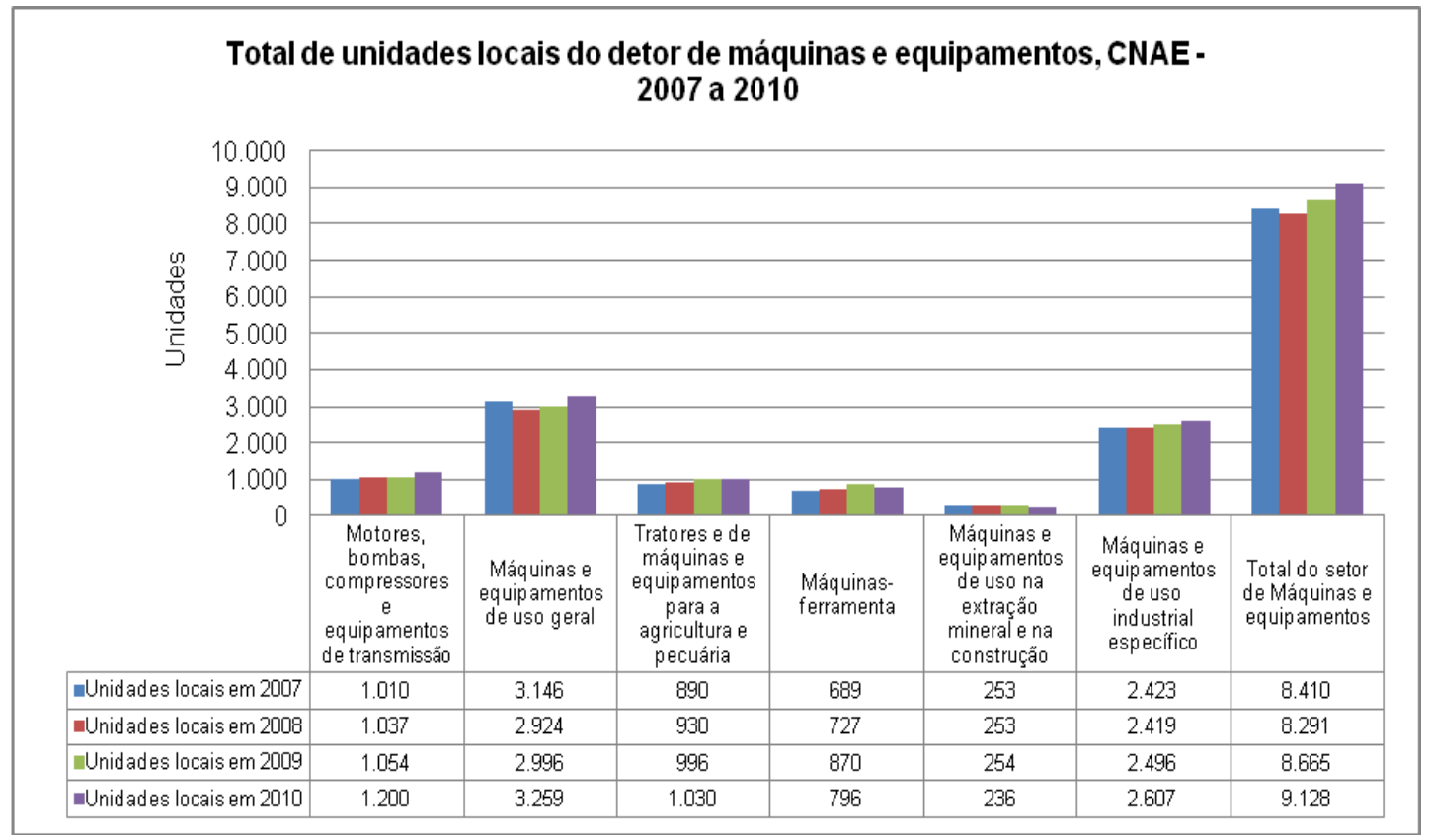

Fonte: IBGE - Pesquisa Industrial Anual Empresa (2012a).

Dados sobre unidades locais com 5 ou mais pessoas ocupadas, segundo as divisões e os grupos de atividades (CNAE 2.0). 
De acordo com os dados do gráfico anterior, pode-se verificar que no período entre 2007 e 2010 os segmentos com maior participação no total de unidades locais (ULs) de máquinas e equipamentos foram Máquinas de uso geral; Máquinas de uso industrial específico; e o segmento Motores e bombas.

Esses três segmentos foram responsáveis, respectivamente, por participação média de 35,5\%, 28,8\% e 12,5\% do total de unidades de produção de máquinas e equipamentos no período entre os anos de 2007 a 2010.

O segmento de máquinas-ferramenta, por sua vez, foi responsável por participação média de $11 \%$ do total de unidades locais existentes no setor de máquinas e equipamentos no mesmo período. Além disso, esse segmento apresentou aumento do número de unidades locais no período entre 20072008 e 2008-2009; e queda do número de empresas no ano de 2010, relativamente a 2009 .

O setor de máquinas e equipamentos, por sua vez, apresentou queda do número de unidades locais em 2008 e aumento das unidades nos períodos seguintes, como pode ser verificado na tabela 5.2.

Tabela 5.2 - Crescimento do número de unidades locais com produção de máquinas-

ferramenta do Brasil - 2007 a 2010

\begin{tabular}{|c|c|c|c|}
\hline Setor de máquinas e equipamentos & $\begin{array}{c}\text { Crescimento } \\
2008-07 \\
(\%)\end{array}$ & $\begin{array}{c}\text { Crescimento } \\
2009-08 \\
(\%)\end{array}$ & $\begin{array}{c}\text { Crescimento } \\
2010-09 \\
(\%)\end{array}$ \\
\hline 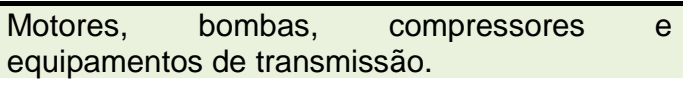 & 2,7 & 1,6 & 13,9 \\
\hline Máquinas e equipamentos de uso geral & $-7,1$ & 2,5 & 8,8 \\
\hline $\begin{array}{l}\text { Tratores e de máquinas e equipamentos para a } \\
\text { agricultura e pecuária }\end{array}$ & 4,5 & 7,1 & 3,4 \\
\hline Máquinas-ferramenta & 5,5 & 19,7 & $-8,5$ \\
\hline $\begin{array}{l}\text { Máquinas e equipamentos de uso na extração } \\
\text { mineral e na construção }\end{array}$ & 0,0 & 0,4 & $-7,1$ \\
\hline $\begin{array}{l}\text { Máquinas e equipamentos de uso industrial } \\
\text { específico }\end{array}$ & $-0,2$ & 3,2 & 4,4 \\
\hline Total do setor de Máquinas e equipamentos & $-1,4$ & 4,5 & 5,3 \\
\hline
\end{tabular}

Fonte: Elaboração própria, com base nos dados da Pesquisa Industrial Anual Empresa, IBGE (2012a).

A distribuição geográfica das unidades com produção de máquinasferramenta do Brasil apresenta participação predominante dos Estados da região sudeste e sul. A tabela 5.3 apresenta o número total de 
estabelecimentos de máquinas-ferramenta por Estados, obtidos na base de dados da RAIS/MTE.

Tabela 5.3 - Total de Estabelecimentos com produção de máquinas-ferramenta, por Estados região sul e sudeste - períodos selecionados

\begin{tabular}{|c|c|c|c|c|c|c|}
\hline \multirow{2}{*}{ Estados } & \multicolumn{2}{|c|}{$\begin{array}{l}\text { Estabelecimentos em } \\
2007\end{array}$} & \multicolumn{2}{|c|}{$\begin{array}{l}\text { Estabelecimentos em } \\
2009\end{array}$} & \multicolumn{2}{|c|}{$\begin{array}{l}\text { Estabelecimentos em } \\
2010\end{array}$} \\
\hline & Unidades & $\begin{array}{c}\text { Participação } \\
(\%)\end{array}$ & Unidades & $\begin{array}{c}\text { Participação } \\
(\%)\end{array}$ & Unidades & $\begin{array}{c}\text { Participação } \\
(\%)\end{array}$ \\
\hline São Paulo & 478 & 57,2 & 515 & 53,9 & 555 & 54,2 \\
\hline Rio Grande do Sul & 128 & 15,3 & 139 & 14,5 & 148 & 14,5 \\
\hline Santa Catarina & 82 & 9,8 & 108 & 11,3 & 118 & 11,5 \\
\hline Paraná & 66 & 7,9 & 84 & 8,8 & 89 & 8,7 \\
\hline Minas Gerais & 56 & 6,7 & 71 & 7,4 & 70 & 6,8 \\
\hline Rio de Janeiro & 15 & 1,8 & 25 & 2,6 & 25 & 2,4 \\
\hline Espírito Santo & 11 & 1,3 & 14 & 1,5 & 19 & 1,9 \\
\hline Total & 836 & 100,0 & 956 & 100,0 & 1024 & 100,0 \\
\hline
\end{tabular}

Fonte: Elaboração própria, com base nos dados da RAIS/MTE (2011).

Dados referentes à classe CNAE 28402: máquinas-ferramenta.

No ano de 2010, destaca-se que Estado de São Paulo apresentava 555 unidades locais de máquinas-ferramenta ou $54,2 \%$ do total de estabelecimentos das duas regiões. Os Estados do Rio Grande do Sul e Santa Catarina, por sua vez, apresentavam, respectivamente, 148 e 118 unidades do segmento de máquinas-ferramenta do Brasil.

$\mathrm{Na}$ análise por microrregiões do Estado de São Paulo, verifica-se que a microrregião de São Paulo é a principal localização das empresas de máquinas-ferramenta no período entre os anos de 2007 e 2010.

De acordo com os dados da RAIS apresentados na tabela 5.4, essa microrregião apresentava 379 estabelecimentos com produção de máquinasferramenta em 2010, o que representava $68,3 \%$ do total de estabelecimentos do segmento localizadas no Estado de São Paulo. 
Tabela 5.4 - Número de estabelecimentos do ramo de máquinas-ferramenta localizados na microrregião de São Paulo

\begin{tabular}{|c|c|c|c|c|c|c|}
\hline \multirow{2}{*}{ Microrregião de SP } & \multicolumn{2}{|c|}{$\begin{array}{l}\text { Estabelecimentos em } \\
2007\end{array}$} & \multicolumn{2}{|c|}{$\begin{array}{l}\text { Estabelecimentos em } \\
2009\end{array}$} & \multicolumn{2}{|c|}{$\begin{array}{c}\text { Estabelecimentos em } \\
2010\end{array}$} \\
\hline & Unidades & $\begin{array}{c}\text { Participação } \\
(\%)\end{array}$ & Unidades & $\begin{array}{c}\text { Participação } \\
(\%)\end{array}$ & Unidades & $\begin{array}{c}\text { Participaçã } \\
\text { o (\%) }\end{array}$ \\
\hline São Paulo & 190 & 56,5 & 200 & 56,0 & 209 & 55,1 \\
\hline Sorocaba & 48 & 14,3 & 50 & 14,0 & 50 & 13,2 \\
\hline Campinas & 38 & 11,3 & 46 & 12,9 & 56 & 14,8 \\
\hline Limeira & 31 & 9,2 & 32 & 9,0 & 36 & 9,5 \\
\hline Bragança Paulista & 29 & 8,6 & 29 & 8,1 & 28 & 7,4 \\
\hline \multirow{2}{*}{$\begin{array}{l}\text { Total desse grupo } \\
\text { Total das microrregiões de } \\
\text { SP }\end{array}$} & 336 & 100,0 & 357 & 100,0 & 379 & 100,0 \\
\hline & 478 & - & 515 & - & 555 & - \\
\hline $\begin{array}{l}\text { Participação das } \\
\text { microrregiões no total de } \\
\text { estabelecimentos de SP (\%) }\end{array}$ & 70,3 & - & 69,3 & - & 68,3 & - \\
\hline
\end{tabular}

Fonte: Elaboração própria, com base nos dados da RAIS/MTE (2011).

Dados referentes à classe CNAE 28402: máquinas-ferramenta

Outra característica importante em relação à estrutura industrial do segmento de máquinas-ferramenta é o porte das empresas com atividades neste segmento. A tabela 5.5 apresenta o total de empresas com produção de máquinas-ferramenta, por faixa de pessoal ocupado, no período entre os anos de 2007 e 2010.

Tabela 5.5 - Número de empresas, por faixa de pessoal ocupado, no segmento de máquinasferramenta do Brasil- 2007 a 2010.

\begin{tabular}{|l|c|c|c|}
\hline \multicolumn{1}{|c|}{$\begin{array}{c}\text { Faixas de pessoal } \\
\text { ocupado }\end{array}$} & \multicolumn{3}{|c|}{ Total de funcionários } \\
\cline { 2 - 4 } & $\mathbf{2 0 0 7}$ & $\mathbf{2 0 0 9}$ & $\mathbf{2 0 1 0}$ \\
\hline Zero & 52 & 60 & 62 \\
\hline De 0 a 4 & 299 & 355 & 380 \\
\hline De 5 a 9 & 165 & 196 & 206 \\
\hline De 10 a 19 & 139 & 172 & 189 \\
\hline De 20 a 49 & 121 & 120 & 130 \\
\hline De 50 a 99 & 35 & 36 & 34 \\
\hline De 100 a 249 & 17 & 11 & 16 \\
\hline De 250 a 499 & 2 & 2 & 3 \\
\hline Acima de 500 & 6 & 4 & 4 \\
\hline Total & 836 & 956 & 1024 \\
\hline
\end{tabular}

Fonte: Elaboração própria, com base nos dados da RAIS/MTE (2011).

Variável categórica: TAMESTAB (Tamanho do estabelecimento) - empregados ativos em 31/12. Dados referentes à classe CNAE 28402: Fabricação de máquinas-ferramenta.

De acordo com os dados apresentados na tabela acima, verifica-se que em 2010 o segmento era formado, principalmente, por empresas de micro e 
pequeno porte, que respondiam, respectivamente, por $81,7 \%$ e $16 \%$ do total de empresas desse ramo ${ }^{37}$.

No período entre os anos de 2007 e 2010, o ramo de máquinasferramenta apresentou aumento de $22,5 \%$ do total de estabelecimentos (de 836 para 1.024). Particularmente entre as empresas participantes da faixa de 10 a 19 funcionários; e de 0 até 4 funcionários, esse crescimento foi mais forte.

As empresas de pequeno e médio porte são especializadas na produção de máquinas-ferramenta seriadas e alguns modelos de máquinas sob encomenda, que são utilizados por vários ramos industriais como automobilístico, metalurgia, instrumentos de precisão, peças e equipamentos para odontologia ${ }^{38}$.

As empresas de grande porte desenvolvem atividades de fabricação de máquinas sob encomenda, destinadas ao atendimento de demandas específicas de indústrias como a automobilística, aviação, extração de petróleo, entre outros.

Apesar dessa distinção entre os dois grupos de empresas, segundo o porte e características gerais da produção, é necessário registrar que o setor de máquinas nacional apresenta capacidade para adaptar e melhorar as linhas de produtos já existentes de acordo com requisitos do cliente ${ }^{39}$.

A produção do setor de máquinas-ferramenta tem apresentado desempenho instável nos últimos três anos. A tabela 5.6 apresenta os dados sobre valor da produção de máquinas-ferramenta no período de 2007 a 2010.

Tabela 5.6 - Valor da produção do segmento de máquinas-ferramenta do Brasil - 2007 a 2010

\begin{tabular}{ccc}
\hline Anos & $\begin{array}{c}\text { Valor da Produção } \\
\text { (RS mil) }\end{array}$ & $\begin{array}{c}\text { Crescimento } \\
\text { da produção (\%) }\end{array}$ \\
\hline 2007 & 3.296 .592 & - \\
2008 & 4.215 .863 & 27,9 \\
2009 & 3.828 .625 & $-9,2$ \\
2010 & 4.413 .968 & 15,3 \\
\hline
\end{tabular}

Fonte: Elaboração própria, com dados da IBGE (2012b). Tabela 3467.

Dados para CNAE 284: Fabricação de máquinas-ferramenta

\footnotetext{
37 A tese utilizou o critério de classificação do porte das empresas (indústria) adotado pelo IBGE: Microempresas: até 19 funcionários; Pequena empresa: de 20 até 99 funcionários; Média empresa: de 100 até 499; Grande empresa: Acima de 500. Fonte: IBGE (2012).

${ }^{38}$ Não foi possível identificar a atual participação percentual dos segmentos usuários no consumo de máquinas-ferramenta nacional.

${ }^{39}$ Essa discussão será retomada na última seção deste capítulo.
} 
No período 2009-2010, o valor da produção do setor de máquinasferramenta apresentou crescimento de 15,2\%, contrastando com a queda do valor da produção de 9,2\% no período 2008-2009.

Um indicador que justifica o baixo desempenho do valor da produção de máquinas-ferramenta é a baixa utilização da capacidade instalada da indústria de transformação ${ }^{40}$ no mesmo período.

De acordo com informações da Confederação Nacional das Indústrias (CNI) apresentadas na tabela 5.7, a indústria de transformação apresentou em 2009 o percentual médio de utilização da capacidade de aproximadamente $79 \%$, considerado o mais baixo do período entre os anos de 2007 a 2010.

Tabela 5.7 - Utilização de capacidade instalada da indústria de transformação (\%) no Brasil 2007 a 2010

\begin{tabular}{lccccccccccccc}
\hline Anos/ & \multicolumn{10}{c}{ Utilização de capacidade instalada } & mensal (\%) & Média \\
meses & $\mathbf{0 1}$ & $\mathbf{0 2}$ & $\mathbf{0 3}$ & $\mathbf{0 4}$ & $\mathbf{0 5}$ & $\mathbf{0 6}$ & $\mathbf{0 7}$ & $\mathbf{0 8}$ & $\mathbf{0 9}$ & $\mathbf{1 0}$ & $\mathbf{1 1}$ & $\mathbf{1 2}$ & anual \\
\hline 2007 & 82,2 & 82,2 & 82,5 & 82,5 & 81,8 & 82,5 & 82,0 & 82,6 & 81,9 & 82,7 & 83.2 & 83,3 & 82,6 \\
2008 & 83,7 & 83,7 & 82,9 & 83,0 & 82,4 & 82,9 & 83,4 & 82,5 & 83,2 & 82,7 & 81,0 & 79,6 & 79,9 \\
2009 & 78,4 & 78,7 & 78,7 & 79,2 & 79,3 & 79,5 & 80,1 & 80,0 & 80,6 & 81,0 & 81,2 & 82,0 & 82,3 \\
2010 & 81,0 & 80,8 & 82,2 & 83,0 & 82,8 & 82,7 & 82,8 & 82,4 & 82,2 & 82,4 & 82,7 & 82,5 & 82,1 \\
2011 & 82,7 & 83,3 & 82,5 & 82,3 & 82,4 & 82,4 & 82,0 & 82,2 & 81,6 & 81,5 & 81,4 & 81,4 & 75,5 \\
\hline
\end{tabular}

Fonte: Adaptado de CNI (2012), p. 07.

Os resultados do valor da produção do setor e a baixa utilização de capacidade instalada no ano de 2009 podem ser atribuídos à revisão ou adiamento dos investimentos do setor frente à queda da demanda de máquinas no mercado interno, particularmente no ano de 2008.

O gráfico 5.3 apresenta os dados de comércio nacional de máquinas e equipamentos no período entre os anos de 1996 e $2010^{41}$

\footnotetext{
${ }^{40}$ Nível de utilização da capacidade instalada (NUCl): indicador que mede a possibilidade de expansão da oferta de produtos industriais. É divulgado mensalmente pela Federação das Indústrias do Estado de São Paulo e pela Confederação Nacional das Indústrias (CNI) em nível nacional (CNI, 2012).

${ }^{41}$ As informações sobre exportações do segmento de máquinas-ferramenta estavam indisponíveis no período da pesquisa. Por esse motivo, foram utilizados os dados de comércio internacional do setor de máquina e equipamentos; e dados de importação dos ramos de máquinas-ferramenta que trabalham com eliminação de material e sem eliminação de material.
} 
Gráfico 5.3 - Comércio de máquinas e equipamentos do Brasil - 1996 a 2010.

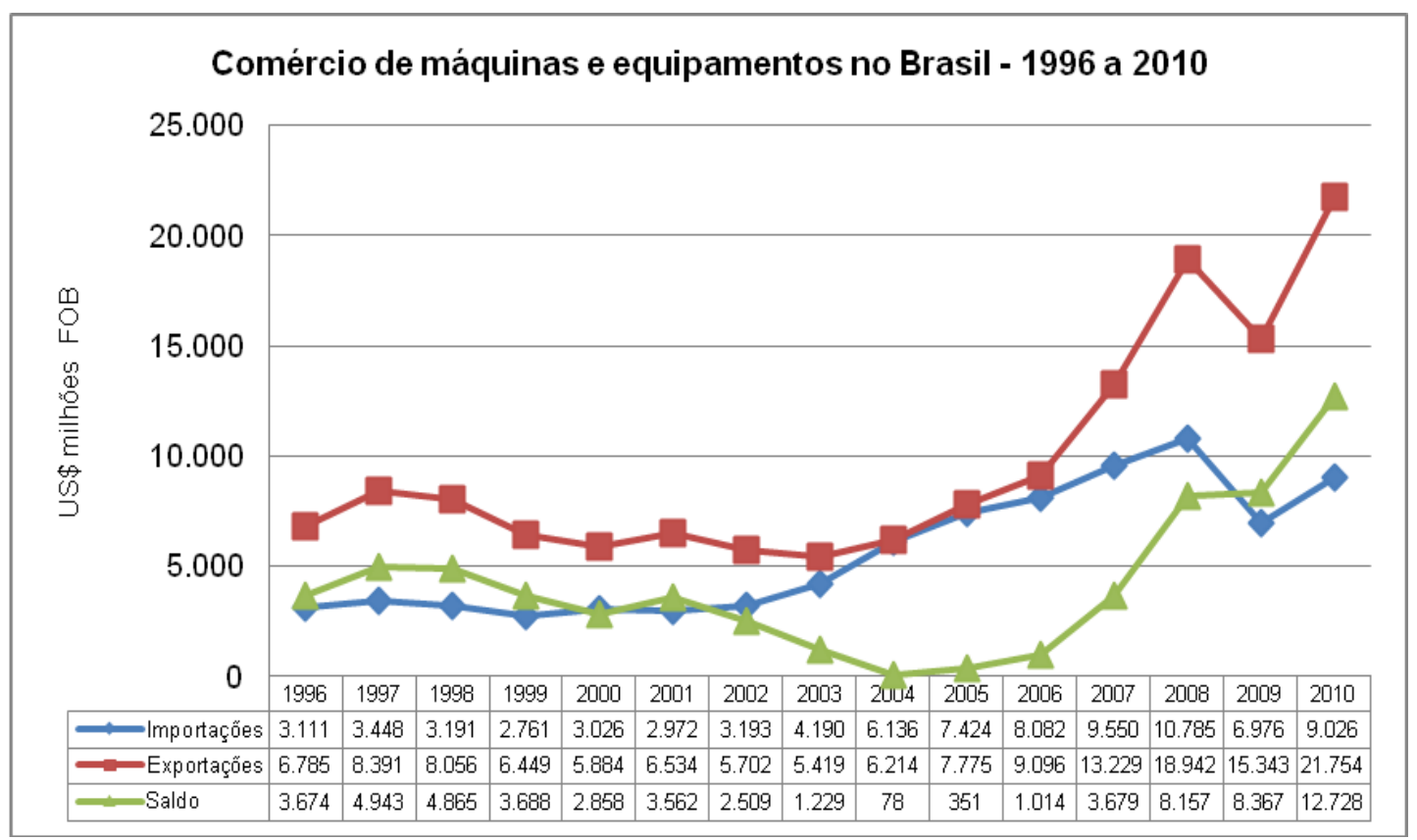

Fonte: Elaboração própria, com base nos dados MDIC/SECEX (2012).

No período entre os anos de 2001 e 2008, o setor de máquinas e equipamentos apresentou aumento dos valores de importação de máquinas. Além disso, os dados de exportação de máquinas apresentaram desempenho positivo entre os anos de 2003 e 2008.

No período entre os anos de 2000 e 2010, as importações de máquinas e equipamentos aumentaram de US\$ 3,02 milhões para US\$ 9.026; enquanto as exportações apresentaram aumento de 5.884 para 21.754. A tabela 5.8 apresenta dados sobre importações do segmento de máquinas-ferramenta do Brasil.

Tabela 5.8 - Importações de máquinas-ferramenta do Brasil, por SITC - 2008 a 2010

\begin{tabular}{|c|c|c|c|c|c|}
\hline $\begin{array}{c}\text { Segmentos de máquinas- } \\
\text { ferramenta }\end{array}$ & $\begin{array}{l}\text { Importações } \\
\text { em } 2008 \\
\text { (US\$ } \\
\text { milhões) }\end{array}$ & $\begin{array}{l}\text { Importações } \\
\text { em } 2009 \\
\text { (US\$ } \\
\text { milhões) }\end{array}$ & $\begin{array}{c}\text { Crescimento } \\
\text { 2009-2008 } \\
(\%)\end{array}$ & $\begin{array}{l}\text { Importações } \\
\text { em } 2010 \\
\text { (US\$ } \\
\text { milhões) }\end{array}$ & $\begin{array}{c}\text { Crescimento } \\
\text { 2010-2009 } \\
(\%)\end{array}$ \\
\hline $\begin{array}{l}\text { Máquinas-ferramenta que } \\
\text { trabalham com eliminação de } \\
\text { metal ou qualquer material } \\
\text { (SITC } 731\end{array}$ & 845,0 & 476,6 & $-43,6$ & 566,8 & 18,9 \\
\hline $\begin{array}{l}\text { Máquinas-ferramenta que } \\
\text { trabalham com metais, sem } \\
\text { eliminação de material (SITC } \\
\text { 733) }\end{array}$ & 397,4 & 420,6 & 5,8 & 375,7 & $-10,7$ \\
\hline Total desse grupo & $1.242,4$ & 897,2 & $-27,8$ & 942,5 & 5,0 \\
\hline
\end{tabular}

Fonte: Elaboração própria, com base nos dados da UN Comtrade (2011). 
De acordo com a tabela, os ramos de máquinas que trabalham com eliminação de material e sem eliminação de material apresentaram queda dos valores de importações em 2008-2009 e pequena recuperação no período seguinte.

Além disso, verifica-se que o ramo de máquinas que executa tarefas de eliminação de material foi mais influenciado pela queda da demanda mundial em 2009. O ramo de máquinas que trabalha com metais sem eliminação de material, por sua vez, apresentou queda das importações relativamente menor e sofreu os efeitos da queda da demanda somente em 2010.

A indústria de máquinas e equipamentos abrange um conjunto de segmentos industriais que apresentam uma diversidade de condições produtivas, competitivas e tecnológicas inter e intra-setoriais

O primeiro fator para explicar a heterogeneidade do segmento de máquinas e equipamentos refere-se às diferenças na escala da produção de máquinas seriadas e sob encomenda.

Os bens de capital seriados apresentam produtos padronizados e fabricados em grande escala, como as máquinas agrícolas e tratores, entre outros.

Nos ramos de bens seriados, as máquinas são produzidas em maior quantidade e apresentam poucas especificações de produto e tecnologias. Neste contexto, as economias de escala são mais importantes para a competitividade das empresas.

A presença de economias de escala é uma das características estruturais das máquinas-ferramenta, que possibilita ganhos de competitividade e a difusão de técnicas para outras indústrias. Entretanto, como o setor de máquinas-ferramenta do Brasil apresenta elevada dependência da demanda no mercado interno, que está sujeito a oscilações de políticas macroeconômicas e fatores conjunturais, os segmentos de máquinas seriadas apresentam dificuldades para manter elevada escala de produção de máquinas.

Os bens sob encomenda apresentam máquinas fabricadas com características técnicas específicas e sob medida, em função da demanda do consumidor (Alem \& Pessoa, 2005, p. 75), como as prensas, alto-fornos, turbinas. 
Nos ramos com fabricação sob encomenda, as máquinas são fabricadas em pequena quantidade e apresentam elevado grau de especificidade em relação ao projeto e às tecnologias incorporadas. Nesse sentido, a presença de economias dinâmicas, atribuídas à experiência e aprendizado contínuo no projeto e processo de desenvolvimento daqueles produtos, assume papel mais importante para o desempenho das empresas (Alem \& Pessoa, 2005, p. 76).

O segundo fator importante para explicar a heterogeneidade entre os segmentos de máquinas é o perfil dos investimentos realizados empresas de máquinas seriadas e sob encomenda.

No segmento de máquinas seriadas, os investimentos em melhorias e incorporação de novas tecnologias tendem a ser diluídos durante a produção de grandes lotes de produtos.

No segmento de máquinas sob encomenda, os esforços destinados à pesquisa, design e desenvolvimento das máquinas sob encomenda estão concentrados em pequenas quantidades de máquinas de alto valor agregado e que são fabricadas sob especificação dos clientes. O prazo para a maturação dos investimentos é relativamente maior porque depende do tempo de duração do projeto e das especificações do cliente.

O maior nível de investimento demandado para a produção de máquinas sob encomenda resulta em barreira à entrada de novas empresas nesse segmento, relativamente às condições apresentadas para as empresas com produção de máquinas fabricadas em série.

Outro fator importante é que o setor de máquinas apresenta condições adversas para investimentos entre os ramos e empresas com produção de máquinas no longo prazo.

As condições do cenário macroeconômico e eventuais mudanças na expectativa em relação aos ganhos econômicos podem intensificar ou restringir os investimentos entre os setores da indústria de transformação.

No cenário de queda do nível de investimentos da indústria, os segmentos de máquinas são os primeiros a sofrer queda da demanda por máquinas. No cenário de recuperação da atividade econômica, os segmentos de máquinas são os últimos a recuperar o seu nível de produção porque dependem da consolidação dos pedidos de diferentes setores usuários. 
O desempenho industrial das empresas está atrelado à sua capacidade para atender à demanda e à competência para resolver eventuais problemas técnicos no processo de produção de máquinas.

A transição entre a fase de realização de melhorias de produto/processo e a fase em que aquela melhoria se torna uma inovação para toda a cadeia dependerá da viabilidade comercial do produto final.

Contudo, os esforços destinados ao desenvolvimento e às melhorias das máquinas apresentam relativa incerteza em relação aos resultados econômicos. E esse fator torna as intenções de investimentos do setor mais tímidas relativamente ao outros setores industriais.

$O$ terceiro fator que influencia a heterogeneidade do setor de bens de capital mecânico é a participação de empresas de grande porte e empresas multinacionais no mercado interno de máquinas.

O segmento de máquinas-ferramenta, por exemplo, tem participação de algumas empresas multinacionais que se estabeleceram no mercado brasileiro a partir da década de 1960 e têm contribuído para o desenvolvimento industrial e as melhorias nas técnicas de produção das máquinas.

Em muitos casos, esses grandes grupos também apresentam melhores condições competitivas e de acesso a linhas de financiamento, o que dificulta o desempenho de empresas de pequeno porte e a inserção de novas empresas no mercado de máquinas.

Um fator primordial para compreender o desempenho do setor de máquinas nas economias industriais é a dinâmica das tecnologias e dos conhecimentos incorporados às máquinas. De maneira geral, as características da estrutura competitiva e tecnológica entre esses segmentos com produção de máquinas podem ser apontados como um possível determinante do desempenho industrial e comercial.

As características da produção e das tecnologias desenvolvidas por empresas de máquinas-ferramenta no longo prazo determinaram 0 desenvolvimento de três faixas de mercado (Avellar, 2008, p. 2):

a. Máquinas de tecnologia tradicional: operadas de forma manual ou semi-automática;

b. Máquinas automáticas, eletrônicas ou não; 
C. Sistemas para produção: incluem as máquinas especiais, os sistemas flexíveis (FMS), as ilhas ou células de produção (CELL), as linhas flexíveis de produção (FML), centro de usinagem e robôs.

De maneira geral, a faixa de mercado de máquinas tradicionais é formada por empresas de micro e pequeno porte, de capital nacional, que são especializadas na produção de máquinas seriadas.

As faixas de mercado de máquinas automáticas e sistemas de produção, por sua vez, são formados por empresas de médio e grande porte que fabricam máquinas seriadas e sob encomenda. Além disso, essas faixas apresentam maior concentração de empresas estrangeiras e empresas nacionais com atuação no mercado interno desde os anos de 1970.

Cada um daqueles grupos (ou faixas de mercado) apresenta diferentes fatores de competitividade, que podem ser atribuídas ao nível de difusão das tecnologias das máquinas no mercado interno e externo.

$\mathrm{Na}$ faixa de mercado de máquinas com tecnologia tradicional, as tecnologias e conhecimentos incorporados as máquina nacionais são amplamente conhecidos e utilizados no cenário internacional. Nesse sentido, o principal fator de competição das empresas com atuação nesses mercados é o preço dos produtos ${ }^{42}$.

$\mathrm{Na}$ faixa de mercado de máquinas que integram tecnologias mais complexas, essas tecnologias e conhecimentos não estão amplamente difundidos entre as empresas.

De maneira geral, essas faixas de mercado apresentam tecnologias que são novidades para grande parte das empresas com atuação no setor. Em outros casos, aquelas empresas concorrentes não apresentam habilidades suficientes para incorporar e difundir tais tecnologias.

Nesse sentido, o principal fator de competitividade das empresas das faixas de mercado de máquinas automáticas e sistemas de produção é a diferenciação do produto.

\footnotetext{
42 Outro fator de competitividade que assume papel importante para o desempenho das empresas dessa faixa de mercado é a flexibilidade para fazer melhorias incrementais aos produtos e o atendimento pósvenda.
} 
Uma importante implicação dessa discussão é que os ramos de máquinas automáticas e sistemas de produção apresentam elevada barreira à entrada, relativamente aos ramos de máquinas tradicionais.

A descrição e análise dos fatores de competitividade para as faixas de mercado de máquinas são importantes para compreender o desenvolvimento do setor no Brasil, mas não são suficientes para explicar as condições competitivas e tecnológicas dos ramos de máquinas-ferramenta do Brasil.

A discussão sobre o desenvolvimento do setor considerando o arcabouço de Sistema Setorial de Inovação e o conceito de regime tecnológico pode contribuir para o entendimento sobre a dinâmica da indústria de máquinas-ferramenta do Brasil. Esse tema será retomado e aprofundado no capítulo sete da tese, com base nas informações obtidas a partir da pesquisa empírica. O próximo capítulo apresenta a metodologia utilizada na pesquisa empírica da tese. 


\section{Metodologia de pesquisa empírica}

A tese apresenta uma análise empírica sobre o desenvolvimento e desempenho recente de empresas de máquinas-ferramenta e de grupos de pesquisas com base na discussão teórica sobre desenvolvimento tecnológico, regime tecnológico e Sistema Setorial. O capítulo com os procedimentos metodológicos da tese foi organizado em quatro seções. A primeira seção apresenta as fases da pesquisa empírica e as fontes de informações utilizadas.

A segunda seção apresenta as os critérios utilizados para selecionar a amostra de empresas de máquinas-ferramenta e os grupos com atividades no ramo de máquinas. Além disso, a seção apresenta dois quadros com a amostra final investigada na pesquisa empírica.

A terceira seção retoma os pressupostos levantados na discussão teórica da tese. Com base nesses pressupostos, a seção apresenta e discute as hipóteses e as questões de pesquisa da tese.

A quarta seção da metodologia apresenta os construtos, o roteiro de questões e as variáveis consideradas nas entrevistas realizadas junto aos representantes das empresas de máquinas-ferramenta e os grupos de pesquisa.

\subsection{Fases da pesquisa e fontes de informações utilizadas}

A metodologia de pesquisa utilizada na tese foi organizada em seis fases. As três primeiras fases da pesquisa empírica abrangem as atividades de levantamento e seleção de informações secundárias sobre produtos, empresas e grupos de pesquisa com atuação no setor de máquinas e equipamentos. As três últimas fases abrangem a elaboração de questionários; a realização de entrevistas e visitas técnicas; e a análise dos resultados obtidos via pesquisa bibliográfica e estudos de caso.

A primeira fase do levantamento de dados consistiu no levantamento de informações que possibilitassem identificar e caracterizar as tecnologias em uso na produção de máquinas-ferramenta nacionais. Já a segunda fase da 
pesquisa bibliográfica consistiu na identificação e seleção de uma amostra de empresas de máquinas-ferramenta com atuação no mercado brasileiro.

As fontes de informações usadas na pesquisa bibliográfica abrangem revistas técnicas e setoriais e jornais de ampla circulação nacional. O quadro 6.1 apresenta as fontes de informação utilizadas na seleção da amostra de empresas.

\begin{tabular}{|c|c|c|c|}
\hline Fontes de informação & $\begin{array}{c}\text { Editorial } \\
\text { consultado }\end{array}$ & Periodicidade & $\begin{array}{l}\text { Endereço } \\
\text { Eletrônico }\end{array}$ \\
\hline \multicolumn{4}{|c|}{ Jornais e revistas de ampla circulação } \\
\hline Revista Exame & $\begin{array}{l}\text { - Melhores e Maiores } \\
\text { Exame (Edições de 2009, } \\
2010 \text { e 2011). } \\
\text { - Portal de notícias }\end{array}$ & Quinzenal & $\begin{array}{l}\text { http://exame.abril.com.br/negoci } \\
\text { os/melhores-e-maiores/ }\end{array}$ \\
\hline Jornal Valor Econômico & $\begin{array}{l}\text { - Revista Valor Grandes } \\
\text { Grupos - impresso } \\
\text { (Edições de 2009, } 2010 \text { e } \\
\text { 2011). } \\
\text { - Portal de notícias }\end{array}$ & $\begin{array}{l}\text { Anual; } \\
\text { Diária; }\end{array}$ & $\frac{\underline{\text { http://www.revistavalor.com.br } / \mathrm{h}}}{\underline{\text { ome.aspx?pub=19\&edicao }=10}}$ \\
\hline \multicolumn{4}{|l|}{ Entidade de representação } \\
\hline Portal da ABIMAQ & $\begin{array}{l}\text { - Informaq (publicação } \\
\text { mensal); } \\
\text { - Datamaq (base de dados } \\
\text { sobre o setor) } \\
\text { - Publicações do } \\
\text { Departamento de } \\
\text { Competitividade e } \\
\text { Estatística (DCEE) }\end{array}$ & Diária & $\begin{array}{l}\text { http://www.abimaq.org.br/ } \\
\frac{\text { http://www.abimaq.org.br/site.as }}{\text { px/Abimaq-Informativo-Mensal- }} \\
\text { Infomaq } \\
\text { http://www.datamaq.com.br/ } \\
\text { http://www.abimaq.com.br/site.a } \\
\text { spx/pginicial DCEE }\end{array}$ \\
\hline $\begin{array}{l}\text { Câmara Setorial de } \\
\text { Máquinas-ferramenta e } \\
\text { Sistemas de } \\
\text { Automação/ABIMAQ }\end{array}$ & $\begin{array}{l}\text { - Lista de associados à } \\
\text { Câmara Setorial de } \\
\text { Máquinas-ferramenta; } \\
\text { - Notícias sobre o } \\
\text { segmento e empresas } \\
\text { associadas }\end{array}$ & Diária & $\begin{array}{l}\text { http://www.camaras.org.br/site.a } \\
\text { spx/Home-CSMF }\end{array}$ \\
\hline Portal IPDMaq/ABIMAQ & - Blog IPDMaq & & $\begin{array}{l}\text { http://www.ipdmaq.org.br/ } \\
\text { http://www.ipdmaq.org.br/ }\end{array}$ \\
\hline \multicolumn{4}{|c|}{ Fonte de informação setorial } \\
\hline $\begin{array}{l}\text { Revista Máquinas Metais } \\
\text { (versão impressa e eletrônica); }\end{array}$ & - Notícias e artigos técnicos & Mensal & $\begin{array}{l}\text { Versão eletrônica a partir da } \\
\text { edição de 11/2011: } \\
\text { http://www.arandanet.com.br/mid } \\
\text { iaonline/máquinas metais/index. } \\
\underline{\text { html }}\end{array}$ \\
\hline $\begin{array}{l}\text { Revista O Mundo da } \\
\text { Usinagem (versão eletrônica); }\end{array}$ & - Notícias e artigos técnicos & Mensal & $\begin{array}{l}\text { http://www.omundodausinagem. } \\
\text { com.br/ }\end{array}$ \\
\hline \multicolumn{4}{|l|}{ Outras fontes } \\
\hline SEADE & $\begin{array}{l}\text { - Investimentos anunciados } \\
\text { no Estado de São Paulo - } \\
2010\end{array}$ & Anual & $\begin{array}{l}\text { http://www.seade.gov.br/produto } \\
\text { s/piesp/consultabanco.php }\end{array}$ \\
\hline
\end{tabular}

Fonte: Elaboração própria.

Quadro 6.1 - Fontes informação utilizadas para a identificação, seleção e análise sobre o setor, empresas e tecnologias do ramo de máquinas-ferramenta do Brasil

A terceira fase do levantamento de informações utilizadas na pesquisa empírica da tese abrange a consulta e identificação de grupos de pesquisa com atuação no ramo de máquinas e equipamentos. 
A principal fonte de consulta utilizada foi o Diretório Grupo de Pesquisa $C N P Q$, que disponibiliza informações sobre os grupos de pesquisa sediados em instituições de pesquisa e ensino (particular e pública) nacionais.

O objetivo principal dessa consulta foi recolher desde dados gerais sobre os grupos como fundação, número de pesquisadores e líderes, as áreas de conhecimento predominante, seus setores de atuação até informações mais específicas como linhas de pesquisa e as interações realizadas com o setor produtivo recentemente.

Após a identificação da amostra de empresas de máquinas-ferramenta e dos grupos de pesquisa, a quarta fase da pesquisa consistiu na elaboração de dois roteiros de questões que foram aplicadas junto aos representantes das empresas e dos grupos de pesquisa.

Os dois roteiros de questões foram elaborados com base nos construtos e questões da revisão teórica da tese.

Após a elaboração dos construtos e questões, a quinta fase da pesquisa foi conduzida através de visitas às unidades industriais das empresas e dos grupos e da aplicação de questionários ${ }^{43}$.

Para obter informações sobre desempenho industrial das empresas e suas interações com atores do sistema Setorial, foi realizado contato com funcionários das áreas de produção; engenharia de produto; P\&D; e Microeletrônica/automação de processos.

Um aspecto importante sobre essa fase da pesquisa é que os dados obtidos nas entrevistas foram mantidos sob sigilo. Nesse sentido, a pesquisa empírica não pretende identificar e classificar eventuais ganhadores ou perdedores no processo de desenvolvimento das máquinas.

A sexta fase da pesquisa abrange a análise das informações obtidas por meio das entrevistas presencias e a análise de dados obtidos através da pesquisa bibliográfica realizada em fontes secundárias e setoriais.

\footnotetext{
${ }^{43}$ Essa fase da pesquisa apresentou papel importante para a conclusão da tese. Em grande medida, as informações obtidas podem ajudar ou dificultar a análise sobre a mudança técnica entre as empresas de máquinas-ferramenta.
} 


\subsection{Objeto de estudo da análise empírica da tese}

A análise empírica da tese pretende captar as características gerais do desenvolvimento tecnológico do setor de máquinas-ferramenta do Brasil

A pesquisa empírica apresenta estudo de casos sobre a atuação de algumas empresas que fabricam máquinas-ferramenta de usinagem no Estado de São Paulo e sobre grupos de pesquisa, também do Estado de São Paulo, com atuação no ramo de máquinas.

A primeira subseção descreve os critérios utilizados para identificar as empresas de máquinas-ferramenta do mercado interno que apresentam unidades produtivas localizadas no Estado de São Paulo.

A segunda subseção deste capítulo apresenta os critérios utilizados para identificar e selecionar os grupos de pesquisa que desenvolvem atividades voltadas ao setor de aplicação máquinas e equipamentos, e que são sediados em instituições de ensino e pesquisa do Estado de São Paulo.

\subsubsection{A Identificação e seleção das empresas de máquinas-ferramenta}

A identificação e seleção das empresas de máquinas-ferramenta da pesquisa empírica da tese foram viabilizadas pela consulta aos jornais de grande circulação, ao sítio eletrônico das entidades de representação do setor e à pesquisa sobre de intenção de investimentos no Estado de São Paulo coordenada pelo SEADE (quadro 6.1)

Os dados das fontes de informação foram comparados com o propósito de identificar uma amostra de empresas com atuação no ramo de máquinasferramenta e que participassem de, pelo menos, três fontes de pesquisa consultadas. Entretanto, apenas duas empresas apresentaram participação em duas fontes de informação. As duas empresas identificadas nessa etapa foram incorporadas à amostra de empresas de máquinas-ferramenta da pesquisa empírica.

É importante registrar_que as fontes setoriais e jornais/revistas de ampla circulação nacional apresentam informações, principalmente, sobre segmentos industriais formados por empresas de grande porte e multinacionais. 
Os segmentos com maior participação de empresas de pequeno e médio porte, como o ramo de máquinas-ferramenta, apresentam carência de informações econômicas e industriais atualizadas que possibilitem compreender o desempenho econômico individualizado ou por segmentos ${ }^{44}$.

Essa condição das estatísticas disponíveis no Brasil sobre o segmento de máquinas-ferramenta refletiu na pesquisa empírica da tese.

Em virtude da pequena participação de empresas de máquinasferramenta nas quatro fontes de pesquisa listadas acima, foram necessários a elaboração de outros critérios que contemplassem um número maior de empresas do setor.

A primeira variável utilizada para identificar e selecionas as empresas de máquinas-ferramenta com unidades de produção localizadas no Brasil é o tipo do produto fabricado. As informações sobre os produtos fabricados por aquelas duas empresas pré-selecionadas foram utilizados como base para a comparação e seleção de outras empresas do setor.

Posteriormente, foi realizada uma consulta ao portal Datamaq (Abimaq) considerando as empresas associadas à Câmara Setorial de Máquinasferramenta e Sistemas de Manufatura (CSMFSM) que fabricam máquinasferramenta utilizadas em processos de usinagem, o que abrange torneamento, fresamento, retificação e centros de torneamento.

A segunda variável utilizada para definir a amostra foi a localização das unidades produtivas daquelas empresas que fabricam máquinas de usinagem. Foram selecionadas as empresas de máquinas-ferramenta com unidades produtivas localizadas no Estado de São Paulo.

A seleção de empresas de máquinas-ferramenta localizadas no Estado de São Paulo pode ser justificada pelo fato de que o Estado é responsável pela maior participação das unidades com produção de máquinas no total de unidades do setor nacional. Além disso, a seleção do Estado de São Paulo permite a cobertura das empresas mais importantes do setor.

Nessa opção metodológica está implícita a idéia de que as regiões com maior concentração de unidades produtivas podem apresentar uma tendência

\footnotetext{
${ }^{44}$ Essas características podem ser atribuídas, principalmente, a dois fatores: a) resistência das empresas de pequeno porte em compartilhar informações de mercado e produtos; b) dificuldade de medir e agregar informações conjunturais e estruturais sobre empresas com características de mercado heterogêneas.
} 
a desenvolver mais interações com outros atores da cadeia como fornecedores, usuários, instituições de ensino e institutos de pesquisa.

A terceira variável utilizada para definir a amostra de empresas de máquinas-ferramenta foi a interação realizada entre essas empresas e os grupos de pesquisa, de acordo com dados divulgados do Diretório de Grupos de Pesquisa CNPQ. Por fim, as empresas identificadas na pesquisa aos dados Datamaq deveriam apresentar produtos similares ou complementares aqueles fabricados por duas empresas já selecionadas na amostra.

O quadro 6.2 apresenta a lista completa de empresas de máquinasferramenta identificadas de acordo com os requisitos citados e que aceitaram colaborar com o estudo da tese $\mathrm{e}^{45}$.

\begin{tabular}{|c|c|c|c|c|c|c|c|c|c|c|}
\hline & \multirow[b]{2}{*}{ Empresas } & \multirow[b]{2}{*}{$\begin{array}{l}\text { Origem da } \\
\text { matriz }\end{array}$} & \multirow[b]{2}{*}{$\begin{array}{l}\text { Localização } \\
\text { da unidade } \\
\text { produtiva }\end{array}$} & \multicolumn{2}{|c|}{ ABIMAQ } & \multirow{2}{*}{$\begin{array}{c}\text { Grupos } \\
\text { CNPQ } \\
\\
\text { Interação } \\
\text { realizada com } \\
\text { grupos de } \\
\text { pesquisa }\end{array}$} & \multirow{2}{*}{$\begin{array}{c}\begin{array}{c}\text { Valor } \\
\text { Econômico }\end{array} \\
\begin{array}{c}\text { Maiores } \\
\text { grupos }\end{array} \\
(2010 \text { e 2009) }\end{array}$} & \multicolumn{2}{|c|}{$\begin{array}{c}\text { Exame Maiores e Melhores - } \\
\text { BK }\end{array}$} & \multirow{2}{*}{$\begin{array}{c}\text { Seade } \\
\text { Investimentos } \\
\text { anunciados } \\
\text { no setor de } \\
\text { máquinas e } \\
\text { equipamentos } \\
\text { - Estado de } \\
S P(2010) \\
\end{array}$} \\
\hline & & & & $\begin{array}{c}\text { Produtos } \\
\text { utilizados } \\
\text { em } \\
\text { processos } \\
\text { de } \\
\text { usinagem }\end{array}$ & $\begin{array}{c}\text { Associado } \\
\text { s CSMF }\end{array}$ & & & $\begin{array}{c}\text { Maiores } \\
\text { empresas em } \\
\text { vendas (2010 } \\
\text { e 2009) }\end{array}$ & $\begin{array}{c}\text { Melhores } \\
\text { empresas } \\
\text { (2010 e 2009) }\end{array}$ & \\
\hline 1 & $\begin{array}{l}\text { B. Grob do } \\
\text { Brasil }\end{array}$ & Alemanha & \begin{tabular}{|l|} 
São \\
Bernardo do \\
Campo/SP \\
\end{tabular} & 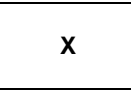 & & & & & & \\
\hline 2 & D.R. Promaq & Brasil & $\begin{array}{l}\text { São } \\
\text { Bernardo do } \\
\text { Campo/SP } \\
\end{array}$ & $x$ & & & & & & \\
\hline 3 & Ergomat & Brasil & \begin{tabular}{|l|} 
São \\
Paulo/SP \\
\end{tabular} & $x$ & $x$ & & & & & \\
\hline 4 & Ferdimat & Brasil & $\begin{array}{l}\text { São José dos } \\
\text { Campos/SP }\end{array}$ & 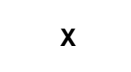 & & & & & & \\
\hline 5 & Index & Alemanha & Sorocaba/SP & $x$ & & $x$ & & & & \\
\hline 6 & $\begin{array}{l}\text { Indústrias } \\
\text { Romi }\end{array}$ & Brasil & \begin{tabular}{|l|} 
Santa \\
Bárbara \\
D'Oeste/SP
\end{tabular} & $x$ & $x$ & $x$ & $x$ & $\mathrm{X}$ & $x$ & $x$ \\
\hline
\end{tabular}

Fonte: Elaboração própria.

Quadro 6.2 - Empresas de máquinas-ferramenta selecionadas para a pesquisa empírica

Vale notar que as empresas apresentadas no quadro têm representatividade em relação ao total de empresas do setor de máquinasferramenta do Estado de São Paulo ${ }^{46}$.

\footnotetext{
${ }^{45} \mathrm{O}$ anexo B apresenta um quadro com as informações principais sobre as empresas de máquinasferramentas que não puderam participar da pesquisa empírica da tese.

${ }^{46} \mathrm{~A}$ tese apresentou dificuldade para mensurar a representatividade em termos de faturamento e número de funcionários das empresas citadas porque não foram encontras essas informações para todas as empresas do setor.
} 


\subsubsection{A identificação e seleção dos grupos de pesquisa}

A identificação dos grupos de pesquisa analisados na pesquisa empírica da tese foi realizada a partir da consulta a três fontes de informação: a) Diretórios Grupos de Pesquisa CNPQ; b) Página eletrônica dos grupos de pesquisa e da IES em que o grupo está inserido; e c) Página eletrônica do currículo lattes dos líderes dos grupos identificados;

O único órgão do Brasil responsável pela divulgação de dados sobre a atuação dos grupos de pesquisa nacionais é o Conselho Nacional de Desenvolvimento Científico e Tecnológico (CNPq).

Os dados disponíveis do Diretório Grupo de Pesquisa CNPq representam importante fonte de consulta sobre grupos e linhas de pesquisa de IES públicas e privadas no cenário nacional

De maneira geral, o sítio eletrônico do Diretório apresenta informações sobre a origem e a atuação dos grupos, destacando as linhas de pesquisa, 0 número de participantes nas categorias líder, pesquisador, alunos e técnicos. Além disso, o sítio apresenta informações sobre as interações realizadas com o setor produtivo. Em alguns casos, as informações divulgadas no sítio do Diretório CNPq não apresentam as atividades acadêmicas e profissionais exercidas pelos grupos de pesquisa e os projetos de pesquisa em andamento no período. As variáveis utilizadas para a seleção dos grupos de pesquisa no Diretório CNPq são apresentadas no quadro 6.3:

\begin{tabular}{|l|l|}
\hline \multicolumn{1}{|c|}{ Variáveis } & \multicolumn{1}{c|}{ Segmentação } \\
\hline Participação do grupo em IES & $\bullet$ Pública ou privada \\
\hline Áreas de atuação da IES & $\bullet$ Ensino e pesquisa \\
\hline Localização do grupo/IES & $\bullet$ Estado de São Paulo \\
\hline Áreas de conhecimento & $\bullet$ Engenharia mecânica e engenharia de produção \\
\hline Setor (produtivo) de atuação dos grupos & $\bullet$ Máquinas-ferramenta. \\
\hline
\end{tabular}

Fonte: Elaboração própria, com base em informações do Diretório Grupo de Pesquisa CNPQ.

Quadro 6.3 - Variáveis utilizadas na seleção dos grupos de pesquisa

De maneira geral, os grupos de pesquisa estão localizados em instituições de ensino e pesquisa sediados no Estado de São Paulo. 
A seleção de grupos de pesquisa sediados no Estado de SP também é atribuída ao papel que o Estado exerce na produção total do setor de máquinas do Brasil.

Considera-se que o fato de haver muitas empresas em SP e a presença de importantes instituições de ensino e pesquisa no Estado podem representar um fator positivo para as interações e aprendizado desses atores do setor de máquinas-ferramenta.

Após a seleção dos grupos de pesquisa inseridos em instituições de ensino (público ou privado) localizadas no Estado de São Paulo, considerou-se dentre esses grupos, apenas aqueles que apresentam atividades acadêmicas nas áreas de conhecimento engenharia de produção e engenharia mecânica.

Após a seleção dos grupos com atuação nessas duas áreas de conhecimento, foram identificados apenas aqueles grupos que desenvolvem atividades para o ramo de máquinas e ferramenta.

O desenvolvimento tecnológico do setor de máquinas e equipamentos e, mais especificamente, o segmento de máquinas-ferramenta engloba uma variedade de linhas de pesquisa e áreas de conhecimento que estão interelacionadas.

Os grupos de pesquisa selecionados a partir dos critérios IES, localização, área de conhecimento e setor de atuação apresentam estudos em uma diversidade linhas de pesquisa.

Para viabilizar a análise empírica, foi necessária a realização de um filtro que possibilitasse a identificação de grupos de pesquisa com atuação em linhas de pesquisa mais relevantes para a tese.

De maneira geral, há dois campos de conhecimento sobre as máquinasferramenta que estão entrelaçados: projeto mecânico e processos de fabricação ${ }^{47}$.

Os grupos de pesquisa com atuação no Brasil apresentam grande variedade de linhas de pesquisa que são contemplados nessas duas áreas de estudo.

\footnotetext{
${ }^{47}$ As características dessas duas áreas foram abordadas no capítulo sobre o setor de máquinas no mundo.
} 
Outro fator importante é que a metodologia utilizada na seleção final dos grupos para a análise empírica esteve apoiada em dois conceitos discutidos na revisão teórica da tese.

Em primeiro lugar, considera-se que o desenvolvimento técnico do setor de máquinas e equipamentos é influenciado por alterações das características dos materiais utilizados na produção das máquinas. As características dos insumos alteram os parâmetros de desempenho das máquinas na execução de tarefas.

Para lidar com essa situação, as empresas de máquinas realizam adaptações à máquina durante o processo de produção. As adaptações, por sua vez, podem integrar o campo de conhecimento sobre projeto e a fabricação de outras máquinas. Entretanto, um fator que pode restringir as adaptações aos modelos de máquinas é a competência e os conhecimentos internos acumulados pela equipe responsável pelo processo de fabricação da máquina.

Em segundo lugar, considera-se que as características dos insumos também influenciaram o desenvolvimento entre as categorias de uso das máquinas-ferramenta. Em especial, as máquinas destinadas às tarefas de usinagem apresentam alterações de seus parâmetros de desempenho dependendo das características do tipo do material trabalhado.

Acredita-se que as máquinas utilizadas no processo de produção em tarefas de corte e perfuração de peças (usinagem) podem representar questão crítica para o desenvolvimento tecnológico do setor de máquinas-ferramenta do Brasil. Por conta desses fatores, a seleção final da amostra de grupos identificou aqueles que preencheram os critérios anteriores, e que desenvolvem pesquisas relacionadas ao processo de produção de máquinas de usinagem.

Para complementar esses dados, foi verificado se esses grupos apresentaram ou apresentam interações com o setor produtivo, de acordo com as informações disponíveis no sítio do Diretório Grupo CNPq.

É importante destacar que o não preenchimento desse requisito não implicou em exclusão dos grupos de pesquisa. As informações foram utilizadas para nortear as entrevistas entre os grupos e as empresas de máquinasferramenta. 
O quadro 6.4 apresenta os grupos de pesquisa de IES sediados no Estado de São Paulo, que desenvolvem pesquisa nas áreas de conhecimento engenharia de produção e mecânica, no setor de aplicação máquinasferramenta. Além disso, esses grupos desenvolvem pesquisas em áreas correlatas ao processo de usinagem ${ }^{48}$.

\begin{tabular}{|c|c|c|}
\hline Grupos & Faculdade e Cidade & $\begin{array}{c}\text { Departamentos/ } \\
\text { Centros }\end{array}$ \\
\hline $\begin{array}{l}\text { Grupo de Pesquisa em } \\
\text { Usinagem por Abrasão }\end{array}$ & $\begin{array}{c}\text { Faculdade de Engenharia e Tecnologia de } \\
\text { Bauru/UNESP (Bauru/SP) }\end{array}$ & Engenharia Mecânica \\
\hline $\begin{array}{l}\text { Núcleo de Desenvolvimento e } \\
\text { Otimização de Processos e } \\
\text { Sistemas Produtivos }\end{array}$ & $\begin{array}{c}\text { Faculdade de Engenharia Arquitetura e } \\
\text { Urbanismo /UNIMEP } \\
\text { (Santa Bárbara D' Oeste/SP) }\end{array}$ & $\begin{array}{l}\text { Programa de Pós-graduação em Engenharia } \\
\text { de Produção }\end{array}$ \\
\hline $\begin{array}{l}\text { Núcleo para Projeto e } \\
\text { Manufatura Integrados }\end{array}$ & $\begin{array}{c}\text { Faculdade de Engenharia Arquitetura e } \\
\text { Urbanismo/UNIMEP } \\
\text { (Santa Bárbara D' Oeste/SP) }\end{array}$ & $\begin{array}{c}\text { Laboratório de Sistemas Computacionais Para } \\
\text { Projeto e Manufatura }\end{array}$ \\
\hline Processos de fabricação & $\begin{array}{c}\text { Faculdade de Engenharia } \\
\text { Mecânica/UNICAMP (Campinas/SP) }\end{array}$ & Engenharia de Fabricação \\
\hline $\begin{array}{l}\text { Dinâmica, Identificação e } \\
\text { Controle de Estruturas }\end{array}$ & $\begin{array}{c}\text { Faculdade de Engenharia } \\
\text { Mecânica/UNICAMP (Campinas/SP) }\end{array}$ & Projeto Mecânico \\
\hline $\begin{array}{l}\text { Usinagem Com altas } \\
\text { velocidades }\end{array}$ & $\begin{array}{c}\text { Escola de Engenharia de São Carlos/USP } \\
\text { (São Carlos/SP) }\end{array}$ & Engenharia de produção \\
\hline $\begin{array}{l}\text { Otimização e Processos de } \\
\text { fabricação }\end{array}$ & $\begin{array}{c}\text { Escola de Engenharia de São Carlos/USP } \\
\text { (São Carlos/SP) }\end{array}$ & Engenharia de produção \\
\hline
\end{tabular}

Fonte: Elaboração própria, com base em informações do Diretório Grupo de Pesquisa CNPq(2012).

Quadro 6.4-Grupos de pesquisa selecionados

Após a identificação e seleção dos grupos, foi realizada uma consulta às informações sobre esses grupos na página eletrônica da instituição de ensino e pesquisa em que eles estão sediados. Além disso, foi realizada uma consulta ao currículo lattes dos líderes dos grupos, com o objetivo de obter informações mais atualizadas e específicas sobre as linhas de pesquisa, atividades acadêmicas e relações com o setor produtivo ${ }^{49}$.

\footnotetext{
${ }^{48} \mathrm{O}$ anexo B apresenta um quadro com as informações principais sobre os grupos de pesquisa que não puderam participar da pesquisa empírica da tese.

49 O Anexo D da tese apresenta as informações obtidas no sítio eletrônico da instituição em que os grupos estão sediados.
} 


\subsection{Construtos, questões e variáveis ${ }^{50}$}

Os construtos podem ser compreendidos como os conceitos principais abordados na discussão teórica da tese. Na fase de organização desses construtos, foi possível identificar algumas questões gerais e as variáveis que explicam essas questões. O quadro 6.5 apresenta os conceitos e construtos da revisão bibliográfica da tese.

\begin{tabular}{|c|c|c|}
\hline Conceitos & Variáveis & $\begin{array}{l}\text { Indicadores } \\
\text { Operacionais }\end{array}$ \\
\hline \multirow{4}{*}{$\begin{array}{l}\text { Regime tecnológico do } \\
\text { setor de MFs }\end{array}$} & Cumulatividade: & \\
\hline & Condições de oportunidade: & \\
\hline & Condições de apropriabilidade: & \\
\hline & $\begin{array}{l}\text { Características do conhecimento-base } \\
\text { interno às empresas: }\end{array}$ & \\
\hline \multirow[t]{2}{*}{ Trajetória tecnológica } & $\begin{array}{l}\text { Fontes de inovação externa ao setor de } \\
\text { MFs: }\end{array}$ & $\begin{array}{l}\text { - Características dos Insumos } \\
\text { usados; } \\
\text { - Fornecedores de componentes } \\
\text { eletrônicos; } \\
\text { - Usuários das máquinas; }\end{array}$ \\
\hline & Fontes de inovação interna ao setor de MFs: & $\begin{array}{l}\text { - Engenharia; } \\
\text { - Engenharia reversa; }\end{array}$ \\
\hline \multirow{6}{*}{ Tecnologias } & Domínio: & $\begin{array}{l}\text { - Científico ou de aplicações ou } \\
\text { ambos; }\end{array}$ \\
\hline & Grau de acessibilidade: & - Oportunidade para inovações \\
\hline & Fonte de informações tecnológicas: & $\begin{array}{l}\text { - Aprendizado, capacidade } \\
\text { organizacional ou feedbacks. }\end{array}$ \\
\hline & Base técnica predominante: & - Produtos ou processos \\
\hline & Caráter pervasivo dos conhecimentos: & - Alto ou baixo \\
\hline & Áreas de conhecimento envolvidas: & $\begin{array}{l}\text { - Produção, mecânica, } \\
\text { microeletrônica, materiais, física. }\end{array}$ \\
\hline \multirow{2}{*}{$\begin{array}{l}\text { Características gerais do } \\
\text { processos produtivo }\end{array}$} & Especialização ou diversificação & \\
\hline & Nível de sinergia com outras áreas & \\
\hline \multirow{2}{*}{$\begin{array}{l}\text { Características específicas } \\
\text { do processo produtivo }\end{array}$} & $\begin{array}{l}\text { Principais requisitos para a produção de } \\
\text { máquinas seriadas: }\end{array}$ & $\begin{array}{l}\text { - Produção: escala, escopo, } \\
\text { flexibilidade; } \\
\text { - Tecnologias de automação }\end{array}$ \\
\hline & $\begin{array}{l}\text { Principais requisitos para a produção de } \\
\text { máquinas sob encomenda }\end{array}$ & $\begin{array}{l}\text { - Produção: escala, escopo, } \\
\text { flexibilidade; } \\
\text { - Tecnologias de automação }\end{array}$ \\
\hline \multirow{2}{*}{$\begin{array}{l}\text { Características do Sistema } \\
\text { Setorial de Inovação de } \\
\text { máquinas-ferramenta }\end{array}$} & $\begin{array}{l}\text { Papel das empresas da cadeia de máquinas } \\
\text { (fabricantes, fornecedores e concorrentes): }\end{array}$ & $\begin{array}{l}\text { - Redes e relações no interior do } \\
\text { sistema; } \\
\text { - Processo de aprendizado entre } \\
\text { os atores; } \\
\text { - Desenvolvimento de tecnologias, } \\
\text { melhorias em produtos e } \\
\text { processos; } \\
\end{array}$ \\
\hline & $\begin{array}{l}\text { Atuação de instituições (pesquisa, ensino, } \\
\text { apoio, fomento): }\end{array}$ & $\begin{array}{l}\text { - Processo de aprendizado entre } \\
\text { os atores; } \\
\text { - Desenvolvimento de tecnologias, } \\
\text { melhorias em produtos e } \\
\text { processos; }\end{array}$ \\
\hline
\end{tabular}

Fonte: Elaboração própria, com base na revisão teórica e setorial da tese

Quadro 6.5 - Conceitos e construtos utilizados na pesquisa empírica

${ }^{50} \mathrm{O}$ anexo $\mathrm{C}$ apresenta os questionários aplicados junto aos representantes das empresas de máquinasferramenta e dos grupos de pesquisa. 
As questões e variáveis da revisão teórica foram trabalhadas para 0 contexto do setor de máquinas e equipamentos, visando a elaboração do questionário que foi aplicado junto aos representantes das empresas de máquinas-ferramenta e dos grupos de pesquisa. $O$ quadro 6.6 apresenta 0 roteiro de questões aplicadas em empresas de máquinas-ferramenta.

\begin{tabular}{|c|c|}
\hline Temas (questões) gerais & Características gerais \\
\hline \multirow{6}{*}{ Produção } & - Principais fabricantes no segmento da empresa (Brasil e mundo); \\
\hline & - Características dos produtos. \\
\hline & - Características dos processo; \\
\hline & - Informações sobre etapas da produção das empresas; \\
\hline & - Características dos tecnologias; \\
\hline & - Características dos serviços; \\
\hline \multirow{4}{*}{ Desempenho industrial recente } & - Vendas no mercado interno e externo (principal produto ou cliente); \\
\hline & - Concorrência; \\
\hline & - Principais Clientes (setores e empresas); \\
\hline & - Principais fornecedores (setores e empresas); \\
\hline \multirow{2}{*}{$\begin{array}{l}\text { Características do desenvolvimento } \\
\text { de produtos }\end{array}$} & $\begin{array}{l}\text { - Fatores que impulsionam o desenvolvimento e melhorias das } \\
\text { tecnologias }\end{array}$ \\
\hline & - Fatores importantes na parte técnica (máquinas) \\
\hline \multirow{2}{*}{$\begin{array}{l}\text { Fontes de informação (produto, } \\
\text { tecnologias e mercado) utilizadas. }\end{array}$} & - Participação em feiras e outros eventos (nacional e internacional) \\
\hline & - Interações com outros atores \\
\hline \multirow{3}{*}{ Capacidade de inovação } & - Características da engenharia (processo de produção, projeto) \\
\hline & $\begin{array}{l}\text { - Vetores para o desenvolvimento de tecnologias no mercado interno e } \\
\text { externo. }\end{array}$ \\
\hline & - Formas de financiamento utilizadas nas atividades inovativas \\
\hline \multirow{4}{*}{ Interações com o Sistema Setorial } & - Interações com instituições de ensino; \\
\hline & - Interações com instituições de pesquisa; \\
\hline & - Interação com clientes (empresas); \\
\hline & - Interações com fornecedores e concorrentes; \\
\hline
\end{tabular}

Fonte: Elaboração própria, com base na revisão teórica e setorial da tese.

Quadro 6.6 - Roteiro de questões e variáveis de controles aplicados nas visitas às empresas de máquinas-ferramenta

Os quadros 6.7 até 6.10 apresentam as características mensuradas na pesquisa empírica entre empresas de máquinas-ferramenta:

\begin{tabular}{|l|l|}
\hline \multicolumn{1}{|c|}{$\begin{array}{c}\text { Características gerais do desempenho } \\
\text { industrial }\end{array}$} & \multicolumn{1}{c|}{ Características mensuradas } \\
\hline Capacidade produtiva & \\
\hline Total de produção (unidades) & • Máquinas de usinagem ou dar forma \\
\hline Tipos de produtos fabricados & $\begin{array}{l}\text { • Máquinas de tecnologias tradicionais, } \\
\text { automáticas ou sistemas de produção; }\end{array}$ \\
\hline Faixas de mercado das máquinas-ferramenta &
\end{tabular}

Fonte: Elaboração própria, com base na revisão teórica e setorial da tese.

Quadros 6.7 - Variáveis mensuradas na análise sobre o desenvolvimento industrial das empresas de máquinas-ferramenta selecionadas 


\begin{tabular}{|l|l|}
\hline \multicolumn{1}{|c|}{$\begin{array}{c}\text { Características gerais do desempenho } \\
\text { econômico }\end{array}$} & \multicolumn{1}{c|}{ Características mensuradas } \\
\hline Vendas (unidades e R\$) & \\
\hline Exportações & $\begin{array}{l}\text { • Principais produtos exportados; } \\
\text { •Principais países de destino das máquinas }\end{array}$ \\
\hline Importações & $\begin{array}{l}\text { •Principais produtos importados; } \\
\text { • Principais países de origem das máquinas }\end{array}$ \\
\hline Investimentos previstos & \\
\hline Investimentos realizados & \\
\hline
\end{tabular}

Fonte: Elaboração própria, com base na revisão teórica e setorial da tese.

Quadro 6.8 - Variáveis mensuradas na análise sobre o desenvolvimento econômico das empresas de máquinas-ferramenta selecionadas

\begin{tabular}{|l|l|}
\hline \multicolumn{1}{|c|}{$\begin{array}{c}\text { Características gerais sobre o panorama } \\
\text { tecnológico do setor }\end{array}$} & \multicolumn{1}{c|}{ Características mensuradas } \\
\hline $\begin{array}{l}\text { Características das linhas de produtos } \\
\text { desenvolvidos }\end{array}$ & $\begin{array}{l}\bullet \text { Máquinas de usinagem (torneamento, } \\
\text { fresamento, retificação, outros) ou } \\
\bullet \text { Máquinas de dar forma. }\end{array}$ \\
\hline $\begin{array}{l}\text { Características das melhorias/mudança } \\
\text { técnica }\end{array}$ & $\bullet$ Incremental ou radical; \\
\hline $\begin{array}{l}\text { Áreas de conhecimento envolvidas no } \\
\text { processo de desenvolvimento/melhorias }\end{array}$ & $\bullet$ Engenharia de produção e mecânica \\
\hline Principais dificuldades enfrentadas & $\bullet$ Econômicas (macro), técnicas, outras. \\
\hline
\end{tabular}

Fonte: Elaboração própria.

Quadros 6.9 - Variáveis mensuradas sobre o panorama dos produtos e tecnologias nas empresas de máquinas-ferramenta

\begin{tabular}{|c|c|c|}
\hline Foco da inovação & Técnica & Organizacional \\
\hline Produto & & \\
\hline Processo & & \\
\hline \multicolumn{2}{|c|}{ Fonte: Adaptado de Wengel \& Shapira }
\end{tabular}

Quadro 6.10 - Características mensuradas na análise sobre a capacidade inovativa das empresas de máquinas-ferramenta selecionadas

\begin{tabular}{|c|c|}
\hline $\begin{array}{c}\text { Características gerais das interações entre } \\
\text { as empresas e o SSI }\end{array}$ & Características mensuradas \\
\hline Interações com usuários: & $\begin{array}{l}\text { - Dinâmica, resultados e eventuais dificuldades para } \\
\text { as empresas; }\end{array}$ \\
\hline Interações com fornecedores: & $\begin{array}{l}\text { - Dinâmica, resultados e eventuais dificuldades para } \\
\text { as empresas; }\end{array}$ \\
\hline Interações com concorrentes: & $\begin{array}{l}\text { - Dinâmica, resultados e eventuais dificuldades para } \\
\text { as empresas; }\end{array}$ \\
\hline $\begin{array}{l}\text { Interações com Instituições de ensino e } \\
\text { pesquisa e institutos (grupos de pesquisa): }\end{array}$ & $\begin{array}{l}\text { - Dinâmica, resultados e eventuais dificuldades para } \\
\text { as empresas; }\end{array}$ \\
\hline Interações com outros atores (apontar): & $\begin{array}{l}\text { - Dinâmica, resultados e eventuais dificuldades para } \\
\text { as empresas; }\end{array}$ \\
\hline
\end{tabular}

Fonte: Elaboração própria, com base na revisão teórica e setorial da tese.

Quadro 6.11 - Características mensuradas na análise sobre as interações das empresas com o Sistema Setorial de Inovação 
Após a identificação de questões e a elaboração do questionário aplicado junto aos representantes das empresas de máquinas-ferramenta, foi elaborado um roteiro com questões que permitissem analisar a dinâmica dos grupos de pesquisa selecionados.

O quadro 6.12 apresenta o roteiro de questões aplicadas junto aos representantes dos grupos de pesquisa com atuação no setor de máquinas. Os quadros 6.13 a 6.15 apresentam outras características mensuradas na análise empírica da tese.

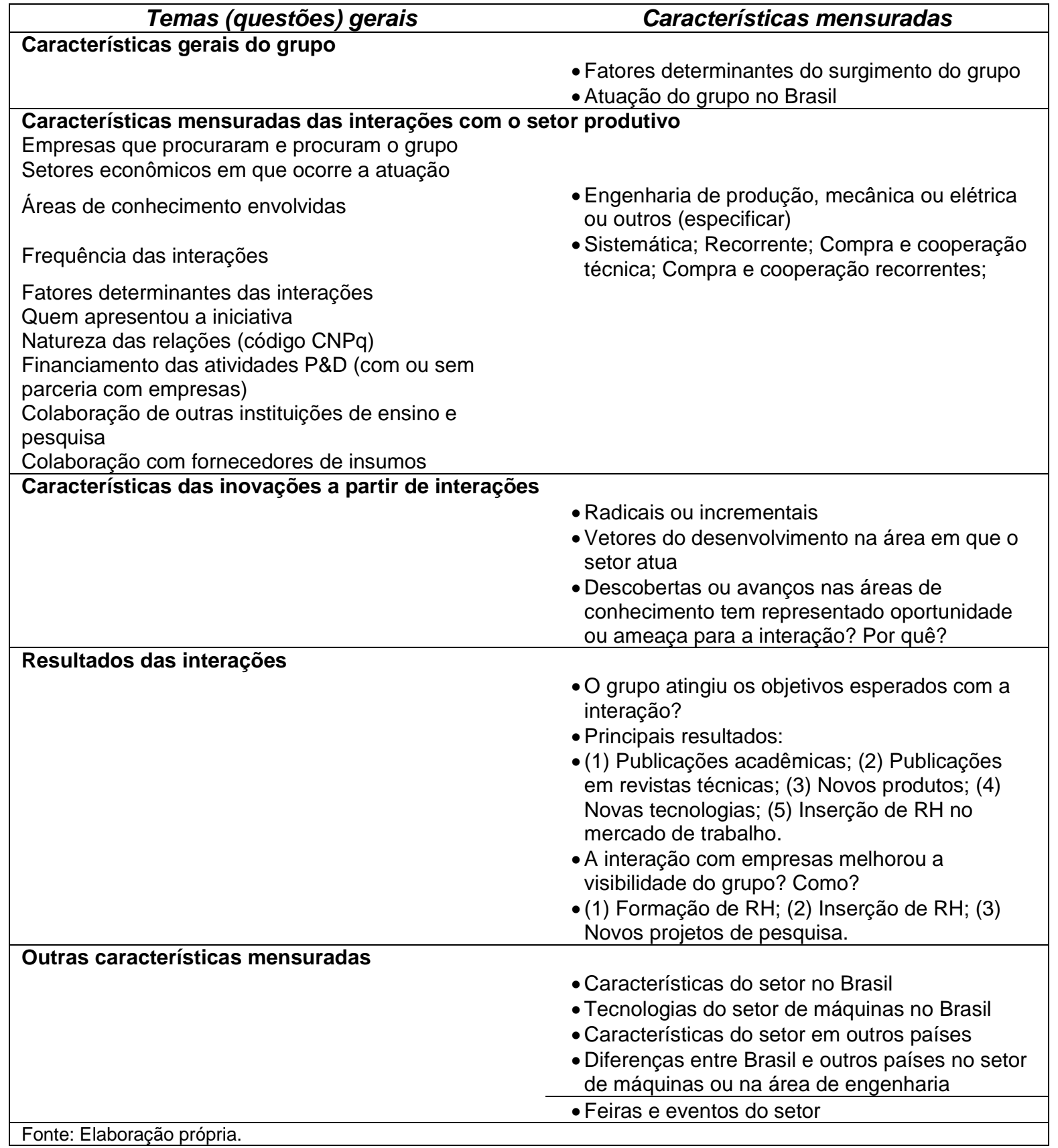

Quadro 6.12 - Roteiro de questões e variáveis de controles aplicados nas visitas aos grupos de pesquisa 


\begin{tabular}{|c|c|c|l|c|}
\hline Grupo & $\begin{array}{c}\text { Departamento/ } \\
\text { Instituição - } \\
\text { Cidade }\end{array}$ & $\begin{array}{c}\text { Ano de } \\
\text { fundação }\end{array}$ & $\begin{array}{c}\text { Áreas de conhecimento } \\
\text { em que atua }\end{array}$ & $\begin{array}{c}\text { Linhas de } \\
\text { pesquisa }\end{array}$ \\
\hline & & & $\begin{array}{l}\text { Engenharia de produção; } \\
\text { Engenharia mecânica. }\end{array}$ & \\
\hline & & & & \\
\hline
\end{tabular}

Fonte: Elaboração própria. Informações obtidas a partir de consulta ao Diretório Grupo de pesquisas CNPq (2012).

Quadro 6.13 - Características gerais dos grupos de pesquisa selecionados

\begin{tabular}{|l|c|c|}
\hline \multirow{2}{*}{ Grupo } & \multicolumn{2}{|c|}{ Interações recentes relatadas } \\
\cline { 2 - 3 } & Setores & Empresas \\
\hline & & \\
\hline
\end{tabular}

Fonte: Elaboração própria. Informações obtidas a partir de consulta ao Diretório Grupo de pesquisas CNPq (2012).

Quadro 6.14 - Grupos de pesquisa selecionados e interações recente registradas com o setor produtivo

\begin{tabular}{|l|l|}
\hline \multicolumn{2}{|c|}{ Tipo de interação } \\
\hline Código CNPq & Descrição \\
\hline & \\
\hline
\end{tabular}

Fonte: Elaboração própria. Informações obtidas a partir de consulta ao Diretório Grupo de pesquisas CNPq (2012).

Quadro 6.15 - Grupos de pesquisa selecionados e características gerais das interações 


\section{Capítulo 7 - Estudo empírico sobre o setor de máquinas- ferramenta}

\subsection{Empresas de máquinas-ferramenta e as características das interações mensuradas com o setor}

Essa seção apresenta as características das empresas de máquinasferramenta analisadas e as interações realizadas entre essas empresas e grupos de pesquisa nos últimos anos. A seção está dividida em cinco partes que abrangem os seguintes temas:

a) Características gerais das empresas de máquinas-ferramenta ${ }^{51}$.

b) Fatores de competitividade das empresas de máquinas-ferramenta.

c) Desempenho industrial e comercial das empresas.

d) Capacidade inovativa das empresas de máquinas-ferramenta considerando dois fatores: características da área de engenharia das empresas; e características do processo de produção e melhoria das máquinas.

e) Características das interações realizadas entre as empresas de máquinas-ferramenta e três categorias de atores do Sistema Setorial: fornecedores; usuários; e Instituições de ensino e pesquisa.

\subsubsection{Características gerais das empresas de máquinas-ferramenta}

A amostra de empresas de máquinas-ferramenta analisada na pesquisa empírica da tese é formada por empresas de capital nacional e estrangeiro que apresentam unidades de produção no Estado de São Paulo. O quadro 7.1 apresenta as características gerais das empresas de máquinas-ferramenta analisadas.

\footnotetext{
${ }^{51} \mathrm{O}$ anexo $\mathrm{D}$ da tese apresenta a nota técnica sobre as empresas visitadas na pesquisa empírica.
} 


\begin{tabular}{|c|c|c|c|c|c|}
\hline \multicolumn{2}{|r|}{ Empresas } & \multirow{2}{*}{$\begin{array}{c}\text { Nacionalidade } \\
\text { Alemanha }\end{array}$} & \multirow{2}{*}{$\begin{array}{l}\text { Porte } \\
\text { Grande }\end{array}$} & \multirow{2}{*}{$\begin{array}{c}\begin{array}{c}\text { Ano de } \\
\text { fundação } \\
\text { (matriz e filial BR) }\end{array} \\
\begin{array}{c}\text { Alemanha: } 1926 \\
\text { Brasil: } 1956\end{array}\end{array}$} & \multirow{2}{*}{$\begin{array}{c}\text { Localização } \\
\text { (unidade no Brasil) } \\
\text { São Bernardo do Campo/SP }\end{array}$} \\
\hline 1 & B. Grob & & & & \\
\hline 2 & $\begin{array}{l}\text { D. R. } \\
\text { Promaq }\end{array}$ & Brasil & Micro & 1986 & $\begin{array}{c}\text { São Bernardo do Campo/SP } \\
\text { (desde 1999) }\end{array}$ \\
\hline 3 & Ergomat & Brasil & Médio & 1962 & São Paulo/SP \\
\hline 4 & Ferdimat & Brasil & Médio & 1970 & São José dos Campos/SP \\
\hline 5 & Index & Alemanha & Grande & $\begin{array}{c}\text { Alemanha: } 1944 . \\
\text { Brasil: } 1973\end{array}$ & Sorocaba/SP \\
\hline 6 & Romi & Brasil & Grande & 1930 & Santa Bárbara D’Oeste/SP \\
\hline
\end{tabular}

Quadro 7.1 - Características gerais das empresas de máquinas-ferramenta selecionadas

A partir das informações divulgadas sobre os números de funcionários ${ }^{52}$, as empresas multinacionais podem ser classificadas como grande porte; enquanto as empresas de capital nacional podem ser classificadas como pequeno e médio porte.

As empresas analisadas têm atuação consolidada no mercado nacional na produção de uma variedade de linhas de produtos. Em alguns casos, as empresas também oferecem serviços de reforma de máquinas usadas, o que é bastante utilizado por empresas usuárias de pequeno e médio porte instaladas no mercado interno ${ }^{53}$. O quadro 7.2 apresenta informações sobre os tipos produtos fabricados e revendidos pelas empresas analisadas.

\footnotetext{
${ }^{52}$ As informações sobre número de funcionários foram obtidas nas entrevistas e não serão divulgadas para manter o sigilo.

${ }^{53}$ Os serviços de assistência técnica e a reforma de máquinas são utilizados por fabricantes de máquinas do mercado interno para promover a fidelização de clientes e a troca de informações sobre produtos e processos. Esse assunto será retomado na seção 7.2.5.
} 


\begin{tabular}{|c|c|c|c|c|c|c|}
\hline \multirow[b]{2}{*}{ Máquinas } & \multicolumn{6}{|c|}{ Empresas } \\
\hline & B. Grob & $\begin{array}{c}\text { D. R. } \\
\text { Promaq }\end{array}$ & Ergomat & Ferdimat & Index & Romi \\
\hline Centros de torneamento & & & & & $\mathbf{x}$ & $\mathbf{x}$ \\
\hline Centros de usinagem & & $\mathbf{x}$ & $x$ & $\mathbf{x}$ & & $\mathbf{x}$ \\
\hline Fresadora & & & $\mathbf{x}$ & $\mathbf{x}$ & & \\
\hline Mandriladora & & & & 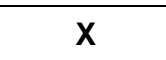 & & $x$ \\
\hline Retificadora & & & & $\mathbf{X}$ & & \\
\hline Torno horizontal & & & & & $\mathbf{x}$ & $\mathbf{x}$ \\
\hline Torno vertical & & $\mathbf{x}$ & 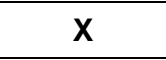 & & $x$ & $\mathbf{x}$ \\
\hline Máquinas-ferramenta especiais & $x$ & $\mathbf{x}$ & & & & \\
\hline Linhas Transfer & $\mathbf{x}$ & & & & & \\
\hline Sistemas Flexíveis & $\mathbf{x}$ & & & & & \\
\hline Soluções de sistemas & $\mathbf{x}$ & & & & & \\
\hline Células & & $\mathbf{x}$ & & & & \\
\hline
\end{tabular}

Fonte: Elaboração própria, com base nas informações disponíveis no Portal Datamaq/Abimaq e dados do sítio eletrônico das empresas.

Quadro 7.2 - Empresas de máquinas e linhas de produtos

Os produtos fabricados pela amostra de empresas apresentam características distintas em relação às tecnologias embutidas e às especificações dos componentes utilizados $^{54}$. Essas especificidades conferem algumas variações aos tipos de máquinas dentro de uma mesma linha ${ }^{55}$.

As máquinas-ferramenta fabricadas pelas empresas analisadas podem ser agrupadas de acordo com as suas tecnologias em três faixas de mercado: tecnologia tradicional, máquinas automáticas e sistemas de produção.

\footnotetext{
${ }^{54}$ A tese apresentou preocupação em abranger empresas que fabricam diferentes linhas de máquinas e a diversidade de modelos dentro de cada linha.

${ }^{55} \mathrm{O}$ anexo $\mathrm{C}$ apresenta as informações detalhadas sobre as linhas e tipos de máquinas fabricados pela amostra de empresas de máquinas-ferramenta.
} 


\begin{tabular}{|c|l|l|}
\hline $\begin{array}{c}\text { Faixas de mercado de } \\
\text { máquinas-ferramenta }\left(^{*}\right)\end{array}$ & \multicolumn{1}{|c|}{ Máquinas } & \multicolumn{1}{|c|}{$\begin{array}{c}\text { Características principais das } \\
\text { tecnologias embarcadas }\end{array}$} \\
\hline $\begin{array}{c}\text { Máquinas de tecnologia } \\
\text { tradicional }\end{array}$ & $\begin{array}{l}\text { Tornos convencionais; } \\
\text { Fresadoras }\end{array}$ & $\begin{array}{l}\text { Podem ser operadas de forma manual ou } \\
\text { semi-automática; }\end{array}$ \\
\hline Máquinas automáticas & $\begin{array}{l}\text { Tornos automáticos, universais e } \\
\text { multifusos. } \\
\text { Fresadora CNC; } \\
\text { Mandrilhadoras CNC; } \\
\text { Retificadoras; }\end{array}$ & $\begin{array}{l}\text { Esse grupo abrange as máquinas } \\
\text { eletrônicas ou não. }\end{array}$ \\
\hline Sistemas para produção & $\begin{array}{l}\text { Máquinas especiais; } \\
\text { Sistemas flexíveis; } \\
\text { llhas ou células de produção; } \\
\text { Linhas flexíveis de produção; } \\
\text { Centro de usinagem e robôs; } \\
\text { Centros de torneamento. }\end{array}$ & $\begin{array}{l}\text { Esse grupo abrange máquinas que } \\
\text { apresentam elevado nível de automação. }\end{array}$ \\
\hline
\end{tabular}

Fonte: Sítio das empresas e dados obtidos na pesquisa empírica.

(*) Conceito sobre 'faixas de mercado' das máquinas: Adaptado de Avellar (2008).

Quadro 7.3 - Faixas de mercado e características das tecnologias embarcadas

A faixa de mercado de máquinas com tecnologia tradicional é formada por empresas nacionais de pequeno e médio porte, que se especializaram na produção de máquinas simples e em pequenas modificações no projeto e tecnologias utilizadas.

O grupo de máquinas com tecnologia convencional abrange tornos convencionais e máquinas fresadoras, que apresentam baixa complexidade tecnológica ou que incorporam conhecimentos e processos mais simples. As máquinas podem apresentar algumas variações nas características físicas, como diâmetro, quantidade de ferramentas acopladas, mas de maneira geral, trabalham com o mesmo tipo de material.

Além disso, esse grupo de máquinas é formado por alguns modelos considerados 'standard', que são relançados com algumas modificações de componentes, sem mudar o projeto inicial, visando o atendimento da demanda no mercado interno. As máquinas de usinagem, por exemplo, podem apresentar diferenças em relação ao número de eixos, quantidade de ferramenta que são acopladas à porta-ferramentas, e as tecnologias de comando numérico utilizadas. Essas diferenças são atribuídas às características da peça que a máquina foi projetada para trabalhar e da quantidade de tarefas designadas para essa máquina. 
De maneira geral, as máquinas com tecnologia tradicional são fabricadas no mercado interno há algumas décadas e que têm boa aceitação entre os consumidores por apresentar preços mais acessíveis.

As faixas de mercado de máquinas automáticas e sistemas de produção, por sua vez, são formados por empresas de médio e grande porte, nacionais e estrangeiras, que fabricam máquinas com maior quantidade de componentes e tecnologias com maior complexidade tecnológica.

Essas máquinas podem trabalhar com peças que exigem uma quantidade maior de tarefas ou apresentam parâmetros menores para a execução dessas tarefas. O modelo de torno a cames, por exemplo, é uma máquina seriada que apresenta dispositivo mecânico para tornear peças executando tarefas mais simples; o torno de carros múltiplos é uma máquina fabricada sob encomenda, que pode realizar tarefas mais complexas. Outro exemplo de máquina desse grupo é a máquina de usinagem com variações de 3 a 5 eixos.

Por conta das características das tecnologias presentes nessas máquinas, seu preço é relativamente mais alto do que o preço praticado para as máquinas tradicionais.

As empresas de máquinas-ferramenta visitadas fabricam produtos sob encomenda para consumidores do mercado interno e externo. Os principais setores usuários das máquinas-ferramenta das empresas selecionadas na pesquisa empírica são a indústria automobilística e seus fornecedores (02 empresas); empresas prestadoras de serviços de usinagem, tornearias e ferramentaria (06 empresas); componentes médicos e odontológicos; telecomunicações; eletrodomésticos e aviação e gás (01 empresa).

Vale notar que o desempenho industrial dos usuários de máquinasferramenta exerce papel decisivo sobre as vendas e as estratégias de investimentos do setor de máquinas no mercado interno ${ }^{56}$.

As empresas de máquinas-ferramenta da amostra utilizam, principalmente, capital próprio em suas estratégias produtivas, tecnológicas e

\footnotetext{
${ }^{56}$ Essa discussão será retomada e aprofundada na seção sobre Dinâmica industrial e comercial do setor de máquinas.
} 
de mercado. Entre essas empresas, algumas já utilizaram recursos da FINEP ${ }^{57}$ para desenvolvimento de produto.

A principal fonte de acesso ao financiamento por parte dos clientes que compram as máquinas fabricadas por essas empresas é o FINAME (utilizado por quatro empresas).

As empresas de máquinas-ferramenta da amostra estão atuando no mercado interno há aproximadamente 50 anos. Desde a sua fundação, essas empresas resistiram às várias fases de declínio da produção nacional de máquinas, o que pode ser atribuído às competências incorporadas e à revisão de suas estratégias de atuação nas fases de queda e aquecimento da demanda.

As competências acumuladas ao longo do tempo resultaram em variedade de linhas de produtos que são utilizados, principalmente, por empresas usuárias do mercado interno. Além disso, as empresas visitadas apresentam flexibilidade para adaptar suas linhas de produtos às especificidades da demanda, o que representa um diferencial em relação às empresas de máquinas do mercado externo.

Por conta desses fatores, é possível afirmar que as empresas de máquinas-ferramenta exercem papel importante para $\circ$ desenvolvimento industrial e tecnológico da indústria de transformação do Brasil.

As próximas seções discutem o desempenho das empresas, as características do desenvolvimento de tecnologias e as interações realizadas entre as empresas visitadas e outros atores.

\footnotetext{
${ }^{57}$ A tese reconhece a importância dos instrumentos públicos de financiamento e incentivo tecnológico dos setores industriais. Entretanto, optou-se por não realizar uma análise aprofundada sobre políticas públicas de apoio e incentivo ao desenvolvimento do setor de máquinas-ferramentas do Brasil.
} 


\subsubsection{Fatores de competitividade das empresas de máquinas-ferramenta}

A competitividade das empresas de máquinas-ferramenta analisadas na pesquisa empírica depende, principalmente, de dois fatores: preço e condições técnicas das máquinas.

O primeiro fator de competitividade identificado para as empresas de máquinas-ferramenta visitadas é o preço dos produtos vendidos no mercado interno.

Esse fator está diretamente relacionado aos custos de produção das máquinas. De maneira geral, o custo do material e da mão-de-obra utilizados no processo de produção das máquinas e os custos impostos pelo ambiente macroeconômico (taxa de juros, câmbio) refletem no preço de venda da máquina-ferramenta nacional.

Os custos diretos e indiretos de produção refletem no preço das máquinas nacionais e dificultam a atuação das empresas no mercado interno e externo, principalmente entre as empresas de pequeno porte.

O preço da máquina é o principal fator de competitividade para as empresas com atuação na faixa de mercado de máquinas mais tradicionais, como alguns modelos de tornos e fresadoras.

Um dos fatores que explica a concorrência em preços é que os conhecimentos em mecânica incorporados a esses produtos estão amplamente difundidos entre empresas do mercado interno e externo. Os funcionários das empresas visitadas, por exemplo, apresentam relativa facilidade para incorporar conhecimentos e promover pequenas adaptações ao produto. A difusão de conhecimentos no ambiente interno dessas empresas, por sua vez, apresenta duas consequências para o seu desempenho no mercado interno e externo.

Em primeiro lugar, a possibilidade de realizar pequenas melhorias no produto repercute em baixa barreira à entrada de novas empresas na faixa de mercado de máquinas-ferramenta tradicionais. Esse fato pode ser ilustrado pelo elevado número de empresas de micro e pequeno porte com atuação no mercado brasileiro.

Em segundo lugar, como os conhecimentos incorporados aos produtos ou processos apresentam característica incremental e são facilmente 
transmitidos através de interações entre funcionários, a competitividade da empresa que desenvolveu a melhoria na máquina é bastante frágil. No curto prazo, uma melhoria realizada na mesma base de conhecimentos por empresas concorrentes é suficiente para 'liquidar' a vantagem competitiva da empresa que antes apresentava ganhos de mercado.

As máquinas de retificação apresentam uma exceção a essa condição porque os conhecimentos em tecnologias de precisão não estão tão difundidos no mercado interno. Mesmo nesse caso, a pesquisa empírica identificou que as empresas de retificação com atuação no mercado interno têm apresentado concorrência em preço.

Com base nessas informações, verifica-se que a competitividade baseada, exclusivamente, no preço dos produtos se tornou um obstáculo para a manutenção e o desempenho das empresas de máquinas no mercado interno e externo.

O segundo fator de competitividade identificado para as empresas de máquinas-ferramenta visitadas abrange as características técnicas e de produção das máquinas.

As características técnicas abrangem aspectos como a tolerância das máquinas na execução de tarefas e as condições para trabalhar com diferentes materiais e apresentar maior produtividade; e a capacidade de trabalhar com projetos simples ou adaptar projetos existentes para atender requisitos da demanda. Além disso, pode-se destacar a qualidade do processo de produção executado pela máquina e 0 tempo gasto na produção das peças para 0 cliente.

As características técnicas e do processo de produção de máquinas são fatores de competitividade importante para as empresas com atuação nas faixas de mercado de máquinas automáticas e sistemas de produção.

De maneira geral, as transformações nas características dos materiais utilizados em setores como aviação, petróleo e gás e a indústria automobilística, a rapidez verificada no processo produtivo daqueles setores e as exigências em relação à qualidade do produto final influenciaram a adaptação e as melhorias das máquinas-ferramenta.

Nesse cenário, as características técnicas dos materiais, das ferramentas e componentes eletrônicos incorporados às máquinas podem 
conferir às empresas desse setor um melhor desempenho na realização de suas tarefas.

No processo de produção das peças em materiais mais resistentes, como o aço inox, por exemplo, o trabalho da máquina é relativamente diferente do trabalho realizado em peças de outros tipos de aços.

No primeiro caso, a máquina deve operar com velocidade menor para usinar peças com as especificações demandadas. Isso porque o aumento da velocidade de trabalho pode provocar o superaquecimento da máquina e a danificação da máquina e do material trabalhado. Em materiais menos resistentes, por sua vez, a máquina pode executar as tarefas com maior velocidade e avanço diferente.

A flexibilidade para adaptar produtos às especificações dos consumidores também é um fator de competitividade importante para as empresas com atuação no ramo de máquinas-ferramenta, principalmente, aquelas que desenvolvem sistemas de produção.

De maneira geral, essas empresas apresentam pequena equipe de funcionários que são responsáveis por adaptações e melhorias no projeto de produto, visando 0 atendimento de especificações do consumidor. Frequentemente, essa flexibilidade para mudar os projetos de máquinas está apoiada em habilidades e na experiência daqueles funcionários do ambiente interno das empresas ${ }^{58}$.

A qualidade do processo de produção e a otimização do tempo gasto na produção de peças são fatores importantes para a competitividade, principalmente, de empresas que desenvolvem sistemas de produção e máquinas automáticas. Nas empresas visitadas que desenvolvem sistemas de produção, por exemplo, há uma preocupação em incorporar componentes e ferramentas que permitam a produção com melhor qualidade e que utilizem o menor tempo possível na execução de cada tarefa.

É importante registrar que as alterações nas características técnicas das máquinas e a flexibilidade para adaptar projetos são preocupações mais comuns entre as empresas com produção sob encomenda.

\footnotetext{
${ }^{58}$ A análise sobre capacidade produtiva e inovativa das empresas visitadas é apresentada na seção 7.1.4 da tese.
} 
A qualidade do processo de produção e o tempo gasto a realização de cada tarefa, por sua vez, são preocupações que estão implícitas no processo produtivo de qualquer máquina e qualquer porte da empresa. Entretanto, esses dois fatores são mais importantes para o desempenho industrial das empresas que desenvolvem máquinas com tecnologias automáticas ou sistemas de produção.

À medida que se transita para categorias de automáticas e sistemas de produção, as competências são relativamente mais difíceis de imitar porque demandam a atualização de conhecimentos e o aprendizado no ambiente interno às empresas. Por esse motivo, essas faixas de mercado apresentam mais barreiras à entrada de novas empresas. 0 quadro 7.4 resume os fatores de competitividade nas três faixas de mercado de máquinas-ferramenta.

\begin{tabular}{|c|c|c|}
\hline $\begin{array}{c}\text { Faixas de mercado de } \\
\text { máquinas-ferramenta }\end{array}$ & $\begin{array}{c}\text { Principal } \\
\text { fator de competitividade }\end{array}$ & $\begin{array}{c}\text { Barreiras à } \\
\text { entrada de novas } \\
\text { empresas }\end{array}$ \\
\hline $\begin{array}{c}\text { Máquinas de tecnologia } \\
\text { tradicional }\end{array}$ & Preço & Baixa \\
\hline Máquinas automáticas & $\begin{array}{c}\text { Preço (em menor } \\
\text { grau),características técnicas dos } \\
\text { produtos, flexibilidade para adaptar } \\
\text { projeto; }\end{array}$ & $\begin{array}{c}\text { Baixa ou Alta } \\
\text { (depende do tipo do } \\
\text { produto) }\end{array}$ \\
\hline Sistemas para produção & $\begin{array}{c}\text { Qualidade, tecnologias } \\
\text { incorporadas, flexibilidade para } \\
\text { adaptar projeto; Tempo de } \\
\text { execução das tarefas. }\end{array}$ & Alta \\
\hline Fonte: Elaboração própria, com base na pesquisa empírica.
\end{tabular}

Quadro 7.4 - Fator de competitividade e características das barreiras à entrada, segundo as faixas de mercado.

A partir das informações obtidas na pesquisa empírica da tese é possível classificar as empresas com produção de máquinas-ferramenta em dois grupos. O primeiro grupo é formado por três empresas que apresentam capacidade para adaptar projetos, qualidade do produto final e otimização do tempo gasto no processo produtivo como principais fatores de competitividade. O segundo grupo é formado por três empresas de máquinas-ferramenta que apresentam o preço dos produtos como principal fator de competitividade no mercado interno e externo.

Entretanto, como as empresas com produção de máquinas-ferramenta apresentam diversificação de linhas de produtos e diferentes modelos dentro de uma mesma linha, é possível identificar a combinação de todos esses 
fatores de competitividade em uma mesma empresa, dependendo do tipo de produto analisado.

A atuação das empresas em faixas de mercado de máquinas-ferramenta com diferentes fatores de competitividade apresenta algumas implicações importantes para o desempenho industrial e tecnológico do setor de máquinas no mercado interno. A próxima seção analisa as informações qualitativas sobre o desempenho industrial e comercial das empresas de máquinas-ferramenta no período recente.

\subsubsection{Análise qualitativa sobre o desempenho industrial e comercial das empresas de máquinas-ferramenta selecionadas}

As empresas de máquinas-ferramenta visitadas na pesquisa empírica vendem seus produtos, principalmente, no mercado interno, mas em alguns casos, as empresas vendem algumas linhas de produtos também para 0 mercado externo.

No período entre os anos de 2010 e 2012, essas empresas de máquinas-ferramenta apresentaram queda do seu desempenho industrial e econômico em termos de produção, vendas e investimentos em capacidade instalada. Entretanto, essa condição não é visualizada para as empresas fabricantes de máquinas para todos os setores industriais.

A pesquisa empírica identificou empresas com produção de máquinas voltadas para a indústria automobilística que apresentaram aumento do número de pedidos de máquinas no ano de 2011.

As empresas nessa situação apresentam a revisão das estratégias de investimentos visando à modernização da capacidade produtiva de máquinas. O aumento das vendas tem influenciado o aumento do nível de utilização de sua capacidade produtiva ${ }^{59}$, o que difere do nível de utilização de capacidade verificado para a indústria de transformação.

\footnotetext{
${ }^{59}$ As empresas visitadas não divulgaram dados sobre utilização da capacidade produtiva recente. De acordo com os dados divulgados pela Confederação Nacional das Indústrias, a indústria de transformação nacional apresentou 75,5\% de utilização de capacidade instalada no ano de 2011 . As informações podem ser consultadas na tabela 5.5.
} 
Por outro lado, a pesquisa empírica também identificou empresas com produção de máquinas destinadas a outros setores industriais que apresentaram queda da demanda nos últimos dois anos.

As empresas desse grupo apresentaram queda do número de pedidos e não apresentam planos de investimento em modernização da unidade fabril. Além disso, essas empresas estão revendo estratégias de atuação do mercado nacional e abandonando o desenvolvimento de algumas linhas de produtos.

A pesquisa empírica identificou dois fenômenos que podem ajudar a explicar o desempenho industrial e comercial das empresas de máquinasferramenta e têm influenciado as estratégias industriais das empresas com atuação no ramo de máquinas-ferramenta nacional.

O primeiro fenômeno identificado na pesquisa empírica refere-se à inserção de outros países na produção mundial de máquinas, que concorrem diretamente com os fabricantes brasileiros desde o final da década de 1990. O segundo fenômeno é a queda da demanda mundial de máquinas verificada entre os anos de 2008 e 2009.

De maneira geral, as empresas nacionais e as multinacionais com filiais instaladas no Brasil têm enfrentado aumento da concorrência no comércio internacional de máquinas, principalmente entre os produtos que apresentam tecnologias mais simples.

O mercado de tornos e fresadoras, por exemplo, apresentam maior inserção de empresas estrangeiras, provenientes, principalmente de Taiwan e da China, que apresentam produtos com preços em média até $60 \%$ menor do que os preços praticados por empresas de máquinas do Brasil.

As vendas de máquinas-ferramenta para o mercado externo, por sua vez, apresentaram modificações no volume e no perfil dos países importadores. De acordo com os dados da pesquisa, destaca-se a redução da demanda de máquinas brasileiras por alguns países desenvolvidos da União Européia, da América Latina e os Estados Unidos. Além disso, os países asiáticos têm apresentado participação mais significativa no volume de exportações para o Brasil do que no volume de importações.

Diante dessa situação, algumas empresas nacionais de máquinas ampliaram 0 desenvolvimento de projetos especiais de máquinas sob encomenda. A pesquisa empírica da tese identificou duas empresas de grande 
porte e uma empresa de médio porte que estão investindo no desenvolvimento de competências visando a produção de máquinas especiais.

O desenvolvimento dessa estratégia assumiu papel importante para 0 desempenho industrial e econômico daquelas empresas porque os modelos de máquinas especiais apresentam maior valor agregado e reúnem fatores de competitividade que são mais difíceis de imitar. Desse modo, as empresas que desenvolvem projetos especiais conseguem amenizar a concorrência com produtos provenientes de outros países.

O desempenho das empresas multinacionais com filiais instaladas no Brasil também tem sido afetado pela inserção de outras empresas no setor de máquinas.

Nas últimas décadas, a atuação dessas empresas de máquinas esteve fundamentada pela divisão mundial da produção dos tipos de máquinas nos países em que as empresas apresentam unidades fabris. Naquele cenário, enquanto a matriz produzia máquinas mais sofisticadas, a filial brasileira se especializava na 'nacionalização' de máquinas simples projetadas pela matriz.

As empresas multinacionais com filiais instaladas no mercado brasileiro tem apresentado a revisão de algumas estratégias produtivas e concorrenciais. Há movimento por parte dessas empresas visando novo posicionamento do Brasil na produção mundial de máquinas. De acordo com essa visão, o Brasil se transformaria em nova plataforma de produção de linhas de máquinasferramenta que incorporam especificidades exigidas no mercado interno e podem atender à demanda dos países de industrialização recente.

De acordo com os dados obtidos na pesquisa empírica até o ano de 2008, grande parte das empresas com atuação no ramo de máquinasferramenta do Brasil apresentava resultados positivos das vendas, por conta da alta demanda de máquinas nacionais e as perspectivas de aumento dos investimentos do setor produtivo.

No período entre os anos de 2008 a 2010, a queda da atividade econômica mundial contribuiu para a revisão dos investimentos em capacidade produtiva e influenciou a queda da venda de máquinas no mercado nacional e externo.

A pesquisa empírica identificou três empresas nacionais de máquinasferramenta que estão revendo sua atuação no mercado interno e optando por 
parar a produção de algumas linhas de máquinas. Duas dessas empresas se tornaram representante de empresas de máquinas estrangeiras.

Além disso, a pesquisa identificou empresas de máquinas-ferramenta que estão migrando para a produção de linhas de máquinas um pouco mais sofisticadas ou estão se especializando em projetos sob demanda de clientes, como forma de ampliar suas competências internas.

Com base nas informações apresentadas até aqui, é possível destacar que as empresas com atuação no ramo de máquinas-ferramenta, independente do porte e da origem de capital, têm apresentado condições adversas em seu desempenho industrial. A próxima seção analisa as informações sobre a capacidade inovativa do grupo de empresas de máquinas-ferramenta selecionadas na pesquisa empírica.

\subsubsection{Capacidade inovativa interna das empresas analisadas}

Essa seção apresenta uma análise da capacidade inovativa das empresas de máquinas-ferramenta considerando dois fatores: características da área de engenharia das empresas e características do processo de produção e melhoria das máquinas.

\section{Características da área de engenharia das empresas}

As atividades de engenharia das empresas visitadas estão organizadas, basicamente, em duas subáreas: engenharia de sistemas eletrônicos e engenharia de sistemas mecânicos.

De acordo com os entrevistados, os funcionários vinculados a essas subáreas apresentam boa base de conhecimentos e competências em engenharia, tanto de formação (graduação) como de experiência no ramo. Os funcionários com experiência em engenharia estão trabalhando há mais tempo nas empresas e, nem sempre apresentam a graduação na área correspondente à sua atuação.

Em alguns casos, esses funcionários ocupam funções de projetistas ou assumem papel importante nas etapas de melhorias do projeto das máquinas em virtude das competências e da experiência acumulados ao longo do tempo. 
Os funcionários com graduação em engenharia, por sua vez, também apresentam participação importante no projeto das máquinas.

Especialmente entre as empresas de máquinas-ferramenta com produção destinada também ao mercado europeu, o conhecimento técnico e científico obtido por meio de cursos regulares constitui fator importante para o desenvolvimento e fabricação das máquinas e os avanços em temas correlatos.

As empresas visitadas enfatizaram o papel desempenhado pelos funcionários dessas áreas da engenharia nas etapas de projeto, melhoramento e no processo de fabricação das máquinas.

Particularmente nas etapas de projeto e melhoramento das máquinas, esses funcionários têm atuado no atendimento de especificidades de algumas linhas de produtos.

Algumas empresas de máquinas dispõem de funcionários ou uma equipe que trabalha em conjunto com o departamento de engenharia de produto visando à operacionalização de mudanças específicas.

Além disso, os gerentes das áreas de engenharia mecânica e eletrônica têm atuação importante na prospecção de novas tecnologias ou novas aplicações difundidas através de feiras e eventos do setor.

\section{Processo de produção das máquinas}

As empresas de máquinas visitadas trabalham por projetos (sob encomenda) e contam com a colaboração entre as subáreas de sistemas eletrônicos e mecânicos para operacionalizar as melhorias desses projetos.

As empresas não divulgaram informações sobre tempo médio utilizado na produção das máquinas, mas destacaram que o tempo médio necessário para a execução de cada projeto é diferente, dependendo do tipo da máquina.

As máquinas especiais, os centros de torneamento, os sistemas flexíveis, entre outros, apresentam prazo de produção relativamente maior do que a produção de máquinas seriadas. Aquelas máquinas são projetadas para executar tarefas em peças com muitas especificações em relação ao tamanho, largura, profundidade e detalhamento dos trabalhos, o que reflete em maior complexidade ao processo dependendo do uso final da peça. 
O setor de máquinas-ferramenta tem apresentado redução do tempo médio decorrido desde a programação e a entrega do produto final. Em alguns casos, as empresas de máquinas-ferramenta utilizam informações de mercado e sua experiência na venda desses produtos visando à melhoria da programação da produção. Nesse sentido, para se antecipar às demandas e reduzir o tempo de entrega do produto, há uma preocupação interna à empresa em ampliar suas competências e os conhecimentos sobre mercado.

Nos últimos cinco anos, três empresas adotaram mudanças no processo produtivo das máquinas seja através da reorganização de algumas etapas da produção ou da internalização de atividades correlacionadas à produção de máquinas.

$\mathrm{Na}$ etapa de preparação das peças, por exemplo, o ambiente é climatizado visando à manutenção das características físicas na execucação de tarefas com menor tolerância.

$\mathrm{Na}$ etapa de medição da peça fabricada, os testes são realizados várias vezes antes da usinagem, após a usinagem e junto com o comprador da máquina, para garantir que a máquina adquirida executará as tarefas de acordo com programação e as especificações do cliente.

A etapa em que os componentes eletrônicos são incorporados à máquina e testados é uma das mais importantes no processo de produção. $O$ objetivo principal dessa etapa é verificar se a máquina suporta variações na velocidade de execução das tarefas ou em outros parâmetros. Além disso, o teste de componentes eletrônicos é importante para identificar os resultados dessas variações para o desempenho da máquina ao final de um período de tempo.

A etapa de teste dos componentes eletrônicos demanda mais tempo, seja para testar o funcionamento desses componentes ou para testar as limitações de seu funcionamento na máquina em determinadas condições.

A maior atenção dada a algumas etapas de produção de máquinas tem possibilitado a algumas empresas melhorar a imagem e a confiabilidade das máquinas entre os consumidores no mercado interno.

Outro fator importante é que algumas empresas dispõem de um pequeno estoque de ferramentas, partes e peças usinadas que são utilizadas na produção da máquina. A disponibilidade desse lote permite que a produção 
da parte mecânica da máquina seja efetuada em tempo relativamente menor, contribuindo para a redução do tempo de entrega do produto após a entrada do pedido na fábrica.

Em algumas empresas com produção de máquinas-ferramenta, as atividades de chaparia e funilaria também passaram a ser realizadas dentro da empresa, como forma de garantir a rapidez na entrega das peças que serão trabalhadas pela empresa fabricante da máquina.

As características do material que compõe a peça utilizada no processo de produção das máquinas é um fator que influencia diretamente os parâmetros necessários para o bom desempenho das máquinas. De maneira geral, o modelo da máquina é pré-concebido e fabricado considerando as variações nas características de materiais como aço, alumínio, latão, entre outros.

A qualidade desse modelo de máquina está atrelada à sua capacidade de trabalhar com variedade de materiais, e com diferentes velocidades e profundidade de corte. Além disso, fatores como condutibilidade e a maleabilidade dos materiais influenciam no rendimento da produção e bom acabamento da peça. A máquina tem que estar adaptada para essas diferenças nas características físicas dos materiais.

Por outro lado, essas características também podem influenciar negativamente nas melhorias das máquinas porque impõem limitações técnicas ao projeto de máquinas especiais no futuro.

Para realizar as tarefas considerando essas características, as máquinas podem utilizar tecnologias simples ou sofisticadas e quantidade distinta de ferramentas e componentes.

A interface da máquina com componentes eletrônicos e mecânicos viabiliza a produção das máquinas considerando as características desses materiais.

Os parâmetros de rotação, por exemplo, viabilizam a execução das tarefas com a velocidade necessária para o processo de produção. A potência de corte da máquina obtida através dessa interface possibilita a execução das tarefas com diferentes níveis de velocidade para qualquer material. 
Apesar dessa condição, uma empresa destacou a relevância do desenvolvimento de projetos especiais, como forma de reduzir a concorrência nas linhas de produtos mais simples, como tornos. 


\subsubsection{Características das interações e resultados apontados por empresas de máquinas-ferramenta}

Essa seção apresenta uma discussão sobre as características das interações realizadas entre as empresas fabricantes de máquinas-ferramenta e os seguintes atores do Sistema Setorial de Inovação de máquinas-ferramenta: a) fornecedores; b) usuários; e c) Instituições de ensino e pesquisa.

As interações realizadas entre os fabricantes de máquinas-ferramenta e empresas e instituições pertencentes ao Sistema Setorial de máquinas constitui fator importante para explicar o desenvolvimento de tecnologias e 0 desempenho do setor de máquinas nos últimos anos.

O principal instrumento de interação utilizado por empresas de máquinas-ferramenta de médio e grande porte é a participação em feiras nacionais e internacionais dos ramos de máquinas, matrizaria e automação.

A participação das empresas analisadas em feiras possibilita a ampliação de contatos com fornecedores internacionais do ramo de eletrônica, com fornecedores nacionais e estrangeiros de componentes e ferramentas; e com fornecedores de insumos.

O principal objetivo das visitas às essas feiras é ter acesso a informações que viabilizam a atualização sobre tendências e novos conceitos relacionados à construção das máquinas.

Em alguns casos, os funcionários da área de engenharia visitam as feiras realizadas no mercado interno e externo (principalmente da Alemanha) com o objetivo de também obter informações sobre aplicações que são novidade para o mercado interno, mas não são novas no mercado internacional.

As empresas de máquinas de micro e pequeno porte, por sua vez, utilizam principalmente os contatos com fornecedores e os usuários locais estabelecidos do mercado interno.

Os fornecedores das empresas de máquinas-ferramenta são considerados uma fonte importante de mudança técnica.

Em muitos casos, as interações estabelecidas entre os fabricantes de máquinas e seus fornecedores são baseadas na negociação técnica e na negociação de preços e prazos para a entrega dos componentes que serão 
incorporados às máquinas-ferramenta. Em outros casos, as interações também envolvem o acesso a tecnologias que podem melhorar o desempenho da máquina.

Os fornecedores de dispositivos pequenos, por exemplo, oferecem atualização tecnológica para as empresas de máquinas e impulsionam a busca de inovação e novas concepções para incorporar tais dispositivos. Os fornecedores de tecnologia de comando numérico, por sua vez, oferecem cursos sobre o desempenho de seus produtos e o desempenho das máquinas com esses componentes.

Os representantes das empresas fabricantes de máquinas-ferramenta analisadas na pesquisa empírica destacaram interações realizadas com duas categorias de fornecedores: componentes eletrônicos e materiais (insumos).

Os componentes eletrônicos incorporados às máquinas do Brasil são fornecidos, principalmente, pela empresa japonesa Fanuc, a empresa alemã Siemens e a empresa (japonesa) Mitsubishi.

Uma das principais justificativas para essa concentração no segmento de componentes no mercado interno é que os consumidores das máquinas brasileiras comparam esses produtos com os similares fabricados no exterior. A utilização de componentes da mesma marca utilizada no exterior aumenta a chance de aceitação e a inserção dos produtos nacionais no mercado interno e externo.

De maneira geral, os fabricantes de máquinas europeus apresentam preferência por comandos Siemens, enquanto as empresas de máquinas da América preferem os componentes Fanuc.

De acordo com os entrevistados, a utilização de componentes eletrônicos fabricados por essas empresas pode ser explicada por características econômicas e técnicas dos produtos.

Em primeiro lugar, não há diferenças significativas no preço para incorporar componentes às máquinas, mas alguns componentes fabricados pela Siemens apresentam preço mais acessível que os componentes Fanuc. Em segundo lugar, embora a Siemens apresente uma equipe maior e boa estrutura de assistência técnica nacional, a interface com componentes Fanuc é mais fácil, relativamente aos componentes da empresa Siemens. 
O segmento de fornecedores de insumos, por sua vez, é relativamente menos concentrado que segmento de componentes eletrônicos. As empresas produtoras de máquinas-ferramenta apresentam interações 'homologadas' com várias empresas fornecedoras de insumos, principalmente aquelas localizadas na mesma região/Estado em que a fabricante de máquina está instalada.

A principal justificativa para a seleção de grupo de fornecedores é a preocupação em não comprometer os prazos de entrega do produto final e não ser surpreendido pelo aumento do custo de produção em situações adversas.

As empresas fornecedoras de insumos não são muito especializadas e, em alguns casos, a baixa competência na realização de trabalhos com os materiais influenciaram as empresas fabricantes de máquinas à internalizar essas etapas. Essa é uma característica comum entre as empresas de máquinas-ferramenta que trabalham com fundidos de peças maiores (acima de $20 \mathrm{~kg})$.

As interações realizadas entre os fabricantes das máquinas e seus usuários apresentam caráter comercial ou são organizadas para promover 0 treinamento e a utilização correta das máquinas compradas. Entretanto, há um diferencial em relação ao porte das empresas usuárias que compram as máquinas-ferramenta do mercado interno.

Nas situações em que os clientes das máquinas são empresas de pequeno porte, o principal fator levado em consideração na compra das máquinas é o custo das máquinas e as condições de financiamento para a compra da máquina. Nas situações em que os clientes das máquinas são empresas de grande porte, o principal atributo é a tecnologia incorporada ao produto.

Para algumas empresas de máquinas-ferramenta, o baixo nível de conhecimentos técnicos dos funcionários das empresas usuárias de pequeno porte repercute negativamente no desempenho do setor de máquinasferramenta.

Destaca-se que, em geral, parte dos problemas das máquinas usadas por empresas de pequeno porte são decorrentes da falta de manutenção e da utilização da máquina em condições inadequadas. Nessa situação, as empresas de máquinas entrevistadas consideram que a venda dos produtos 
para esses clientes pode se tornar um empreendimento oneroso no longo prazo porque demanda maior assistência e reparos no produto.

As empresas usuárias de grande porte, por sua vez, apresentam melhores condições técnicas internas para aprender e incorporar informações sobre tecnologias e os componentes necessários ao processo produtivo.

As empresas de máquinas-ferramenta analisadas também destacaram a relevância de interações e parcerias com instituições de ensino. De maneira geral, as interações entre as empresas e a área de ensino e pesquisa são importantes para o desenvolvimento do setor porque podem promover a formação de novas de competências nas áreas de engenharia e em áreas correlatas. Além disso, as interações podem influenciar na atualização e melhoria da qualidade da mão-de-obra disponível no mercado interno.

É possível identificar dois tipos de interações entre empresas fabricantes de máquinas e instituições de ensino: interações visando à formação básica em áreas de engenharia em nível técnico e de graduação; e interações voltadas à formação específica, em nível de pós-graduação.

Os representantes das empresas ressaltaram que os cursos técnicos e de graduação disponíveis no mercado interno oferecem uma boa base para a formação e atualização dos funcionários. Entretanto, em algumas localidades a demanda por funcionários com formação técnica para vagas de estágio é maior que a oferta.

Outro fator importante é que após a finalização do curso, os alunos precisam passar por uma etapa de capacitação interna e teste de conhecimentos específicos, o que demanda tempo e investimentos da empresa de máquina-ferramenta.

Apesar do papel importante atribuído aos cursos de formação básica, três empresas visitadas destacam a estratégia de oferecer a formação básica internamente, com o objetivo de promover a formação técnica para as funções que o funcionário irá executar na empresa. Por conta desses fatores, as interações entre as empresas de máquinas-ferramenta e escolas técnicas podem ser classificadas como esporádica.

A interação realizada entre as empresas e instituições de ensino em nível de pós-graduação apresenta característica não muito distinta da interação efetuada com instituições de formação básica. 
O principal determinante para a realização dessas interações é o acesso a conhecimentos sobre temas correlatos e específicos para o desenvolvimento e melhorias das máquinas. Uma característica positiva dessas interações é que elas são mantidas por um período de tempo relativamente maior, o que abrange desde o início do projeto até a defesa e divulgação do trabalho final.

O funcionário da empresa inicia o curso de mestrado acadêmico ou profissionalizante com o objetivo de ter acesso a informações que ajudarão a melhorar o desempenho das máquinas, seja a partir da resolução de problema específico ou através da incorporação de conhecimento novo para a empresa.

A existência de grupos de pesquisa na instituição de ensino em que o funcionário da empresa está cursando a pós-graduação pode acelerar o seu aprendizado. Nesse sentido, algumas empresas consideram que os Institutos e grupos de pesquisa podem colaborar para o desenvolvimento na área de interesse da empresa.

O processo de interação estabelecido entre esses atores pode resultar não apenas na elaboração de trabalho acadêmico, mas na realização de eventos como workshops interno (empresa) ou externo e palestras. A principal vantagem decorrente da realização desses eventos é que eles podem ampliar as informações nas áreas correlatas à questão de pesquisa; podem acelerar o processo de pesquisa conjunta e contribuir para aplicação desses conhecimentos.

Apesar dessa contribuição para o desenvolvimento tecnológico da máquina e da empresa, a pesquisa identificou apenas três interações entre empresas de máquinas-ferramenta e os grupos de pesquisa e institutos de ensino. A próxima seção apresenta uma análise sobre alguns grupos de pesquisa com atuação no ramo de máquinas e equipamentos que aceitaram colaborar com a pesquisa empírica. 


\subsection{Grupos de pesquisa e as características das interações mensuradas com setor produtivo}

Essa seção descreve as características dos grupos de pesquisa e analisa o perfil e os resultados das interações realizadas entre esses grupos de pesquisa e o setor produtivo nos últimos cinco anos. A discussão desta seção foi dividida em três subseções (temas): a) origem e desenvolvimento dos grupos de pesquisa analisados; b) dinâmica das interações para os grupos de pesquisa selecionados; e c) Resultados das interações para esses grupos.

\subsubsection{Origem e desenvolvimento dos grupos de pesquisa analisados}

A pesquisa empírica da tese analisou sete grupos de pesquisa que estão sediados em instituições de ensino superior do Estado de São Paulo. O quadro 7.5 apresenta informações sobre as instituições e os departamentos em que os grupos estão localizados e os líderes de cada grupo.

\begin{tabular}{|c|c|c|c|}
\hline Faculdade e Cidade & $\begin{array}{c}\text { Departamentos/ } \\
\text { Centros }\end{array}$ & Grupos & Líderes \\
\hline $\begin{array}{c}\text { Faculdade de Engenharia e } \\
\text { Tecnologia de Bauru/UNESP } \\
\text { (Bauru/SP) }\end{array}$ & Engenharia Mecânica & $\begin{array}{l}\text { Grupo de Pesquisa em } \\
\text { Usinagem por Abrasão }\end{array}$ & $\begin{array}{l}\text { - Eduardo Carlos Bianchi } \\
\text { - Paulo Roberto de } \\
\text { Aguiar }\end{array}$ \\
\hline $\begin{array}{c}\text { Faculdade de Engenharia } \\
\text { Arquitetura e Urbanismo /UNIMEP } \\
\text { (Santa Bárbara D' Oeste/SP) }\end{array}$ & $\begin{array}{l}\text { Programa de Pós-graduação } \\
\text { em Engenharia de Produção }\end{array}$ & $\begin{array}{l}\text { Núcleo de Desenvolvimento e } \\
\text { Otimização de Processos e } \\
\text { Sistemas Produtivos }\end{array}$ & $\begin{array}{l}\text { - Alexandre Tadeu } \\
\text { Simon }\end{array}$ \\
\hline $\begin{array}{c}\text { Faculdade de Engenharia } \\
\text { Arquitetura e Urbanismo/UNIMEP } \\
\text { (Santa Bárbara D' Oeste/SP) }\end{array}$ & $\begin{array}{l}\text { Laboratório de Sistemas } \\
\text { Computacionais Para Projeto } \\
\text { e Manufatura }\end{array}$ & $\begin{array}{l}\text { Núcleo para Projeto e } \\
\text { Manufatura Integrados }\end{array}$ & - Klaus Schützer \\
\hline $\begin{array}{l}\text { Faculdade de Engenharia } \\
\text { Mecânica/UNICAMP } \\
\text { (Campinas/SP) }\end{array}$ & Engenharia de Fabricação & Processos de fabricação & $\begin{array}{l}\text { - Anselmo Eduardo Diniz } \\
\text { - Maria Helena Robert }\end{array}$ \\
\hline $\begin{array}{c}\text { Faculdade de Engenharia } \\
\text { Mecânica/UNICAMP } \\
\text { (Campinas/SP) }\end{array}$ & Projeto Mecânico & $\begin{array}{l}\text { Dinâmica, Identificação e } \\
\text { Controle de Estruturas }\end{array}$ & $\begin{array}{l}\text { - Paulo Roberto Gardel } \\
\text { Kurka } \\
\text { - João Mauricio Rosário }\end{array}$ \\
\hline $\begin{array}{c}\text { Escola de Engenharia de São } \\
\text { Carlos/USP } \\
\text { (São Carlos/SP) }\end{array}$ & Engenharia de produção & $\begin{array}{l}\text { Usinagem Com altas } \\
\text { velocidades }\end{array}$ & $\begin{array}{l}\text { - Reginaldo Teixeira } \\
\text { Coelho } \\
\text { - João Fernando Gomes } \\
\text { de Oliveira }\end{array}$ \\
\hline $\begin{array}{c}\text { Escola de Engenharia de São } \\
\text { Carlos/USP } \\
\text { (São Carlos/SP) }\end{array}$ & Engenharia de produção & $\begin{array}{l}\text { Otimização e Processos de } \\
\text { fabricação }\end{array}$ & $\begin{array}{l}\text { - Reginaldo Teixeira } \\
\text { Coelho } \\
\text { - Eraldo Jannone da } \\
\text { Silva }\end{array}$ \\
\hline
\end{tabular}

Fonte: Elaboração própria, com base nos dados disponíveis no Diretório dos Grupos de Pesquisa do Brasil (CNPq), 2012.

Quadro 7.5 - Grupos de pesquisa analisados 
As principais áreas de conhecimento das pesquisas desses grupos são engenharia mecânica e engenharia de produção. As atividades de pesquisa desenvolvidas nessas duas áreas abrangem uma diversidade de linhas de pesquisa. O quadro 7.6 apresenta informações sobre as linhas de pesquisa e área de conhecimento predominante.

\begin{tabular}{|c|c|c|}
\hline Grupos & Linhas de pesquisa & $\begin{array}{l}\text { Área de conhecimento } \\
\text { predominante }\end{array}$ \\
\hline $\begin{array}{l}\text { Grupo de Pesquisa em } \\
\text { Usinagem por Abrasão }\end{array}$ & $\begin{array}{l}\text { - Desgaste de ferramentas, materiais e de órgãos } \\
\text { ativos; } \\
\text { - Desgaste dos materiais; } \\
\text { - Estudo bacteriológico nos fluidos de corte; } \\
\text { - Fadiga dos metais; } \\
\text { - Monitoramento do processo de retificação; } \\
\text { - Otimização do processo de retificação; }\end{array}$ & Engenharia Mecânica \\
\hline $\begin{array}{l}\text { Núcleo de Desenvolvimento e } \\
\text { Otimização de Processos e } \\
\text { Sistemas Produtivos }\end{array}$ & $\begin{array}{l}\text { - Logística Industrial e Gestão da Cadeia de } \\
\text { Suprimentos; } \\
\text { - Processos de fabricação; } \\
\text { - Sistemas de Apoio à Decisão; } \\
\text { - Sistemas de automação; }\end{array}$ & Engenharia de produção \\
\hline $\begin{array}{l}\text { Núcleo para Projeto e } \\
\text { Manufatura Integrados }\end{array}$ & $\begin{array}{l}\text { - Desenvolvimento Integrado do Produto; } \\
\text { - Monitoramento do Processo de Usinagem com } \\
\text { Altíssima Velocidade; } \\
\text { - Usinagem com Altíssima Velocidade; }\end{array}$ & Engenharia Mecânica \\
\hline Processos de fabricação & $\begin{array}{l}\text { - Desenvolvimento de aços e ligas metálicas; } \\
\text { - Processo de fabricação; } \\
\text { - Sistemas de Apoio à Decisão; } \\
\text { - Sistemas de Automação; } \\
\text { - Usinagem dos Metais; } \\
\text { - Projeto Mecânico; }\end{array}$ & Engenharia Mecânica \\
\hline $\begin{array}{l}\text { Dinâmica, Identificação e } \\
\text { Controle de Estruturas }\end{array}$ & - Dinâmica, Identificação e Controle de Estruturas. & Engenharia Mecânica \\
\hline $\begin{array}{l}\text { Usinagem Com altas } \\
\text { velocidades }\end{array}$ & $\begin{array}{l}\text { - Automação, Controle de Monitoramento. } \\
\text { - Engenharia Mecânica e Mecânica dos Sólidos }\end{array}$ & Engenharia Mecânica \\
\hline $\begin{array}{l}\text { Otimização e Processos de } \\
\text { fabricação (OPF) }\end{array}$ & $\begin{array}{l}\text { - Automação, Controle de Monitoramento. } \\
\text { - Automação da Usinagem }\end{array}$ & Engenharia Mecânica \\
\hline
\end{tabular}

Fonte: Elaboração própria, com base nos dados disponíveis no Diretório dos Grupos de Pesquisa do Brasil (CNPq), 2012.

Quadro 7.6 - Linhas de pesquisa e áreas de conhecimento predominante dos grupos de pesquisa analisados

Os grupos de pesquisa começaram suas atividades a partir do final dos anos 80, com o objetivo de estudar temas das áreas de engenharias que não 
eram abordados no ambiente acadêmico nacional. $\mathrm{O}$ quadro 7.7 apresenta 0 ano de fundação e as informações sobre a atuação recente desses grupos.

\begin{tabular}{|c|c|c|}
\hline Grupos & $\begin{array}{c}\text { Ano de } \\
\text { fundação }\end{array}$ & Atuação e objetivos \\
\hline $\begin{array}{l}\text { Grupo de Pesquisa } \\
\text { em Usinagem por } \\
\text { Abrasão }\end{array}$ & 1992 & $\begin{array}{l}\text { "Estuda processos abrasivos, com maior ênfase no processo de retificação. Utiliza } \\
\text { técnicas como inteligência artificial, queima de peças, otimização da aplicação dos fluidos } \\
\text { de corte, melhoria da produtividade e qualidade." }\end{array}$ \\
\hline $\begin{array}{l}\text { Núcleo de } \\
\text { Desenvolvimento e } \\
\text { Otimização de } \\
\text { Processos e } \\
\text { Sistemas Produtivos }\end{array}$ & 1996 & $\begin{array}{l}\text { Desenvolve técnicas de otimização de processos em ambiente fabril e aplicação de } \\
\text { sistemas de monitoramento e controle de processos e apoio de sistemas. O objetivo é } \\
\text { permitir a operação desses processos através de apoio à decisão no gerenciamento do } \\
\text { processo, ou em versões automáticas com sistema especialista dentro do conceito de } \\
\text { fábrica virtual ou conectado à WEB. Também trabalha no diagnóstico e correção de falhas } \\
\text { ocorridas em máquinas CNC. }\end{array}$ \\
\hline $\begin{array}{l}\text { Núcleo para Projeto e } \\
\text { Manufatura } \\
\text { Integrados }\end{array}$ & 1995 & $\begin{array}{l}\text { O NPMI nasceu da experiência de um profundo relacionamento com empresas e } \\
\text { universidades visando o desenvolvimento de pesquisa tecnológica e sua apropriação } \\
\text { pelos setores produtivos. Dentro deste enfoque o SCPM foi o primeiro laboratório a trazer } \\
\text { a Tecnologia de Usinagem em Altíssima Velocidade (HSC) para o Brasil, através do } \\
\text { Seminário Internacional de Alta Tecnologia, que vem sendo realizado regularmente desde } \\
\text { 1996. }\end{array}$ \\
\hline $\begin{array}{l}\text { Processos de } \\
\text { fabricação }\end{array}$ & 1983 & $\begin{array}{l}\text { O grupo desenvolve atividades nas áreas de desenvolvimento de processos de fabricação } \\
\text { mecânico-metalúrgico, atuando numa interface entre engenharia mecânica (processos) e } \\
\text { metalúrgica (análise de fenômenos metalúrgicos envolvidos). }\end{array}$ \\
\hline $\begin{array}{l}\text { Dinâmica, } \\
\text { Identificação e } \\
\text { Controle de } \\
\text { Estruturas }\end{array}$ & 1998 & $\begin{array}{l}\text { Desenvolve pesquisas e aplicações de processamento de sinais, análise e controle de } \\
\text { sistemas dinâmicos voltados a máquinas, estruturas e sistemas robóticos. }\end{array}$ \\
\hline $\begin{array}{l}\text { Usinagem Com altas } \\
\text { velocidades }\end{array}$ & 1995 & n.d. \\
\hline $\begin{array}{l}\text { Otimização e } \\
\text { Processos de } \\
\text { fabricação (OPF) }\end{array}$ & 1990 & $\begin{array}{l}\text { Desenvolve pesquisa sobre aplicação de processos de usinagem de precisão. Os } \\
\text { trabalhos abrangem os temas de automação industrial, máquinas inteligentes, usinagem } \\
\text { de precisão e projetos de redução de custos. }\end{array}$ \\
\hline
\end{tabular}

Fonte: Elaboração com base nos dados disponíveis no Diretório dos Grupos de Pesquisa do Brasil (CNPq), 2012.

Quadro 7.7 - Características gerais dos grupos de pesquisa analisados

O principal determinante do surgimento dos grupos de pesquisa visitados foi 0 interesse estritamente acadêmico de professores e pesquisadores das instituições de ensino público e privadas.

De maneira geral, os professores fundadores daqueles grupos iniciaram suas atividades de pesquisa em colaboração com pesquisadores e alunos do departamento ou de outras instituições. O objetivo principal das pesquisas era aprofundar os conhecimentos em alguns temas correlacionados ao processo de fabricação e desempenho das máquinas.

Em alguns grupos, os professores já estudavam o tema em uma instituição do exterior (Alemanha) e decidiram dar continuidade à pesquisa em instituições brasileiras. Em outros grupos, os professores identificaram 
questões de pesquisa que poderiam ajudar a resolver problemas no processo de produção de modelos de máquinas usadas no mercado nacional.

De acordo com alguns pesquisadores entrevistados, no período de fundação desses grupos não havia um reconhecimento das empresas brasileiras sobre o papel da pesquisa acadêmica para o desenvolvimento do setor de máquinas. Além disso, os recursos financeiros para a pesquisa acadêmica nacional eram limitados, o que dificultava a criação de infraestrutura e os primeiros estudos nas áreas de interesse dos grupos.

A partir de 2000, algumas empresas começaram a se interessar por contribuições da pesquisa acadêmica para o seu desempenho industrial. Entretanto, o setor de máquinas não apresentava percepção sobre as vantagens de longo prazo decorrentes das interações entre pesquisa científica e engenharia aplicada. Por esse motivo, as interações entre os grupos de pesquisa e a indústria eram fracas ou nulas.

$\mathrm{Na}$ década de 2010, algumas empresas nacionais passaram a reconhecer a importância da formação dos recursos humanos (graduação e pós-graduação) para o desempenho das atividades internas das empresas.

Por outro lado, grande parte das empresas de máquinas não considera que as universidades possam colaborar com o desenvolvimento de inovações do setor. A partir da pesquisa empírica constatou-se que há um distanciamento entre a pesquisa científica e o desenvolvimento de produtos, principalmente, entre empresas de máquinas de pequeno porte ${ }^{60}$.

Os grupos visitados desenvolvem projetos de pesquisa visando à discussão de questões de sua área de conhecimento ou a resolução de problemas levantados pelo setor produtivo. Além disso, os grupos desenvolvem atividades de prestação de serviços como teste das máquinas e a participação em eventos como workshops e palestras técnicas em temas correlatos à sua área de conhecimento.

Os projetos são conduzidos e operacionalizados por pesquisadores, alunos de pós-graduação, graduação e técnicos que participam dos grupos de pesquisa. O quadro 7.8 apresenta o número de membros de cada grupo estudado, segundo a sua formação.

\footnotetext{
${ }^{60}$ Os fatores que podem justificar esse comportamento das empresas com atuação no ramo de máquinas são analisados na seção 7.3
} 


\begin{tabular}{|l|c|c|c|c|}
\hline \multirow{2}{*}{ Grupos } & \multicolumn{3}{|c|}{ Número de integrantes, por formação acadêmica } \\
\cline { 2 - 5 } & Pesquisadores & $\begin{array}{c}\text { Alunos de } \\
\text { graduação e } \\
\text { pós-graduação }\end{array}$ & Técnicos & $\begin{array}{c}\text { Total } \\
\text { (data) }\end{array}$ \\
\hline $\begin{array}{l}\text { Grupo de Pesquisa em Usinagem por } \\
\text { Abrasão }\end{array}$ & 9 & 51 & 2 & $62(15 / 09 / 12)$ \\
\hline $\begin{array}{l}\text { Núcleo de Desenvolvimento e } \\
\text { Otimização de Processos e Sistemas } \\
\text { Produtivos }\end{array}$ & 12 & 8 & 2 & $22(22 / 02 / 12)$ \\
\hline $\begin{array}{l}\text { Núcleo para Projeto e Manufatura } \\
\text { Integrados }\end{array}$ & 07 & 17 & 02 & $26(19 / 09 / 12)$ \\
\hline Processos de fabricação & 09 & 23 & 04 & $36(30 / 07 / 12)$ \\
\hline $\begin{array}{l}\text { Dinâmica, Identificação e Controle de } \\
\text { Estruturas }\end{array}$ & 07 & 05 & 00 & $12(25 / 11 / 10)$ \\
\hline Usinagem Com altas velocidades & 04 & 13 & 02 & $19(23 / 04 / 12)$ \\
\hline $\begin{array}{l}\text { Otimização e Processos de fabricação } \\
\text { (OPF) }\end{array}$ & 04 & 12 & 02 & $18(23 / 04 / 12)$ \\
\hline
\end{tabular}

Fonte: Elaboração própria, com base nos dados disponíveis no Diretório dos Grupos de Pesquisa do Brasil, CNPQ (2012).

Quadro 7.8 - Número de integrantes dos grupos de pesquisa analisados

O principal setor de aplicação das pesquisas desenvolvidas por esses grupos é 'fabricação de máquina e equipamentos, inclusive máquinasferramenta'.

Para desenvolver as pesquisas em temas relacionados ao processo de fabricação, os pesquisadores e líderes de alguns grupos desenvolvem vínculos com grupos sediados em institutos e instituições de pesquisa localizados no Brasil e no exterior, principalmente a Alemanha. Frequentemente, as pesquisas demandam vínculos informais também com pesquisadores da área de engenharia elétrica e de materiais. O quadro 7.9 apresenta as empresas e grupos que já realizaram interações com os grupos de pesquisa analisados.

\begin{tabular}{|c|c|c|}
\hline Grupos & $\begin{array}{c}\text { Empresas que realizaram interações com } \\
\text { os grupos analisados }\end{array}$ & Interações com outros grupos \\
\hline $\begin{array}{l}\text { Grupo de Pesquisa em } \\
\text { Usinagem por Abrasão }\end{array}$ & $\begin{array}{l}\text { - Nikkon Ferramentas de Corte; } \\
\text { - Agena Resinas e Colas; } \\
\text { - Royall Diamond Ferramentas Diamantadas. }\end{array}$ & $\begin{array}{l}\text { No período de } 1999 \text { a } 2002 \text { o Grupo de } \\
\text { Pesquisa em Usinagem por Abrasão integrou- } \\
\text { se formalmente a Rede Metal Mecânica, Sub- } \\
\text { rede Usinagem, do Programa de Redes } \\
\text { Cooperativas de Pesquisa - RECOPE, } \\
\text { apoiado pela FINEP. } \\
\text { De } 2001 \text { a } 2007 \text { o mesmo grupo integrou-se } \\
\text { ao Instituto Fábrica do Milênio - IFM (versões } \\
1 \text { e 2), apoiado pelo CNPq. }\end{array}$ \\
\hline $\begin{array}{l}\text { Núcleo de } \\
\text { Desenvolvimento e } \\
\text { Otimização de Processos } \\
\text { e Sistemas Produtivos }\end{array}$ & - LabMat Análises e Ensaios Materiais & n.d. \\
\hline $\begin{array}{l}\text { Núcleo para Projeto e } \\
\text { Manufatura Integrados }\end{array}$ & $\begin{array}{l}\text { - Siemens PLM Software do Brasil; } \\
\text { - Sandvik do Brasil; } \\
\text { - Indústrias Romi. }\end{array}$ & $\begin{array}{l}\text { O Núcleo possui parceria com a University of } \\
\text { Tecnology Darmstadt (Alemanha), através da } \\
\text { qual tem ocorrido um intercâmbio científico de } \\
\text { estudantes e de professores, inclusive } \\
\text { gerando uma dissertação de mestrado } \\
\text { agraciada com o Prêmio Schenck na } \\
\text { Alemanha. } \\
\text { É a única entidade na América Latina filiada a } \\
\text { ProSTEP e.V., Alemanha, - associação para } \\
\text { o desenvolvimento de processadores para as }\end{array}$ \\
\hline
\end{tabular}




\begin{tabular}{|c|c|c|}
\hline & & $\begin{array}{l}\text { Normas ISO } 10303 \text { (STEP) com a qual está } \\
\text { realizando um projeto de transferência de } \\
\text { tecnologia visando oferecer os mesmos } \\
\text { serviços na área de Tecnologia de Dados do } \\
\text { Produto, além de sediar a Secretaria Técnica } \\
\text { da ISO para o AP } 214\end{array}$ \\
\hline Processos de fabricação & n.d. & n.d. \\
\hline $\begin{array}{l}\text { Dinâmica, Identificação e } \\
\text { Controle de Estruturas. }\end{array}$ & n.d. & n.d. \\
\hline $\begin{array}{l}\text { Usinagem Com altas } \\
\text { velocidades }\end{array}$ & $\begin{array}{l}\text { - Index Tornos Automáticos Indústria e } \\
\text { Comércio; } \\
\text { - Indústrias Romi; } \\
\text { - Tecno How Engenharia Industrial e } \\
\text { Comércio; } \\
\text { - Saint-Gobain Abrasivos. }\end{array}$ & n.d. \\
\hline $\begin{array}{l}\text { Otimização e Processos } \\
\text { de fabricação (OPF) }\end{array}$ & $\begin{array}{l}\text { - Microma Projetos e Construcões Mecânicas; } \\
\text { - Index Tornos Automáticos Indústria e } \\
\text { Comércio; } \\
\text { - Aços Villares - Matriz; } \\
\text { - Saint-Gobain Abrasivos; } \\
\text { - Indústria de Máquinas Zema. }\end{array}$ & n.d. \\
\hline
\end{tabular}

Fonte: Elaboração própria, com base nos dados disponíveis no Diretório dos Grupos de Pesquisa do Brasil (CNPq), 2012.

Quadro 7.9 - Grupos de pesquisa e interações desenvolvidas recentemente

As atividades de pesquisa conduzidas por esses grupos e os gastos com a infraestrutura física são financiadas, predominantemente, por recurso público $^{61}$. A principal fonte de financiamento das atividades de pesquisa desenvolvidas por esses grupos são as bolsas de iniciação científica ou bolsas de pesquisa em nível de pós-graduação (FAPESP, CNPQ). A concessão de financiamento obtidos por meio da FINEP e FAPESP também é utilizada para financiar as atividades dos grupos de pesquisa.

Os resultados da pesquisa empírica apontam que as empresas de máquinas não disponibilizam seus recursos financeiros para a realização das pesquisas $^{62}$. Em alguns casos, as empresas fornecem as máquinas necessárias para a operacionalização do projeto ao preço abaixo do praticado no mercado.

Desde o surgimento desses grupos, os pesquisadores tem se dedicado a pesquisas em temas relacionados aos processos de fabricação das máquinas por conta da necessidade de compreender e melhorar características técnicas desse processo.

\footnotetext{
${ }^{61}$ A infraestrutura física dos grupos não foi avaliada na pesquisa empírica da tese. Quando questionados sobre as condições internas para a realização das pesquisas, os entrevistados não levantaram pontos negativos que possam influenciar os resultados de suas pesquisas.

62 De acordo com um dos entrevistados, na Alemanha há uma participação mais igualitária dos recursos financeiros de empresas e das universidades e institutos de pesquisa.
} 
Por outro lado, o Brasil apresenta poucos grupos de pesquisa na área de projeto mecânico. Esse fator pode ser atribuído ao fato de que apesar dos pesquisadores apresentarem diferentes filiações, as suas pesquisas apresentam maior preocupação em incorporar avanços na área mecânica ${ }^{63}$.

Com base nas informações obtidas na pesquisa empírica, os avanços em algumas áreas de conhecimento difundidos pelo setor de máquinas do Brasil têm apresentado distanciamento em relação aos avanços nos principais países com produção de máquinas.

A principal justificativa para essa condição é que o ritmo de incorporação, difusão e apropriação dos conhecimentos é relativamente distinto entre as empresas fabricantes de máquinas. Além disso, muitas empresas nacionais não investem na absorção daqueles conhecimentos e na criação de competências internas nas linhas de pesquisas em ascensão.

Nesse cenário, os avanços nos temas de pesquisa podem representar oportunidades para o desempenho do setor de máquinas no mercado internacional. Entretanto, como as empresas não estão preparadas para absorver os conhecimentos, essas mudanças representam uma ameaça, principalmente, para as empresas de pequeno porte.

\subsubsection{Características das interações e principais resultados apontados por grupos de pesquisa}

Essa seção utiliza informações obtidas por meio das entrevistas junto aos representes dos grupos de pesquisa para discutir a dinâmica das interações realizadas entre esses grupos e as empresas de máquinasferramenta do Estado de São Paulo. A discussão abrange os seguintes pontos:

- Setores econômicos em que ocorre a interação;

- As empresas que procuraram e procuram o grupo;

- Áreas de conhecimento envolvidas;

- Natureza das relações;

- Frequência das interações;

\footnotetext{
${ }^{63}$ Um dos entrevistados ressaltou que não há espaço para o desenvolvimento de projetos mecânico no Brasil.
} 
- Determinantes das interações;

- Características das interações;

- Formas de financiamento das atividades P\&D a partir das interações;

- Participação de outras instituições de ensino e pesquisa;

- Principais resultados das interações para os grupos de pesquisa analisados.

A análise sobre a atuação dos oito grupos de pesquisa do Estado de São Paulo identificou que cinco desses grupos apresentou (ou apresenta) alguma interação com a indústria ${ }^{64}$. Além disso, dentre esses cinco grupos que desenvolveram interações com empresas, apenas três desenvolveram pesquisa em parceria com empresas do ramo de máquinas.

De acordo com os representantes dos grupos de pesquisa analisados, o setor de máquinas e equipamentos do mercado interno tem direcionado seus esforços para o atendimento da demanda dos setores automobilístico, aviação e petróleo e gás.

A dinâmica industrial desses setores é relativamente distinta e esse fator reflete no desempenho dos fabricantes das máquinas utilizadas por aqueles setores. Além disso, as perspectivas de crescimento da demanda de máquinas utilizadas por esses setores não refletiu nas interações das empresas fabricantes de máquinas com grupos de pesquisa considerados na pesquisa empírica da tese.

As empresas de máquinas procuram os grupos com o objetivo de melhorar o desempenho do processo de produção de alguns modelos como retificadoras e tornos. Entretanto, há algumas diferenças entre os determinantes das interações dependendo do porte da empresa com produção de máquinas.

As empresas de máquinas-ferramenta de pequeno e médio porte realizam interações com grupos de pesquisa visando à incorporação de soluções simples (pequenas melhorias) aos modelos de máquinas antigos. As empresas de máquinas de grande porte, por sua vez, buscam interações com grupos visando o desenvolvimento e incorporação de soluções tecnológicas mais complexas.

\footnotetext{
${ }^{64}$ Os outros dois grupos de pesquisa não têm atuado em pesquisa acadêmica ou não tem interação
} 
As áreas de conhecimento envolvidas nas interações entre os grupos e as empresas com produção de máquinas são a engenharia mecânica, elétrica, produção e robótica. Além disso, os grupos de pesquisa visitados também apresentam interações com grupos de pesquisa da área de engenharia de materiais.

Em alguns casos, o desenvolvimento dos projetos de pesquisa e a operacionalização da pesquisa são realizados conjuntamente pelo grupo da área de mecânica e os grupos (ou pesquisadores) da área de materiais. Esse comportamento é atribuído ao fato de que os estudos sobre processos e tecnologias das máquinas precisam se adequar às mudanças e características dos materiais do qual a peça é formada.

O grupo de pesquisa detentor do projeto também pode utilizar os laboratórios da engenharia de materiais, como forma de testar os parâmetros das máquinas-ferramenta estudados. Durante esse processo, os grupos de pesquisa analisam as características dos materiais, das ferramentas e dos insumos utilizados na produção dessas máquinas.

A proximidade geográfica entre os grupos de pesquisa com atuação nas áreas de engenharia mecânica e engenharia de materiais é um aspecto importante que age como facilitador da troca de informações entre os grupos.

As interações realizadas nos últimos cinco anos entre os grupos de pesquisa e empresas de máquinas podem ser classificadas, segundo sua natureza, em dois tipos: Pesquisa científica com considerações de uso imediato dos resultados; e Fornecimento, pelo grupo, de insumos materiais para as atividades do parceiro sem vinculação a um projeto específico de interesse mútuo.

Além disso, as interações abrangem as seguintes atividades: pesquisa e melhoria das características das máquinas, compra de materiais e insumos; treinamento visando a utilização correta de componentes eletrônicos; e o teste de peças.

Em alguns casos, os grupos também colaboraram na elaboração e melhoria de projetos usados pelas empresas para solicitar recursos financeiros junto aos órgãos públicos de financiamento. A pesquisa também identificou um grupo que apresenta interação com empresas fornecedoras de componentes 
para a área dentária com o objetivo de realizar teste dos componentes utilizados por outros setores industriais.

O quadro 7.10 descreve a natureza das interações e a quantidade das interações a partir dos dados fornecidos pelos grupos de pesquisa.

\begin{tabular}{|c|c|}
\hline $\begin{array}{c}\text { Natureza das interações entre empresas e instituições de } \\
\text { pesquisa (1) }\end{array}$ & $\begin{array}{l}\text { Número de } \\
\text { interações }\end{array}$ \\
\hline Pesquisa científica sem considerações de uso imediato dos resultados & 0 \\
\hline Pesquisa científica com considerações de uso imediato dos resultados & 2 \\
\hline $\begin{array}{l}\text { Atividades de engenharia não rotineira inclusive o desenvolvimento de } \\
\text { protótipo cabeça de série ou planta-piloto para o parceiro }\end{array}$ & N.d. \\
\hline $\begin{array}{l}\text { Atividades de engenharia não rotineira inclusive o } \\
\text { desenvolvimento/fabricação de equipamentos para o grupo }\end{array}$ & 0 \\
\hline Desenvolvimento de software não rotineiro para o grupo pelo parceiro & 0 \\
\hline Desenvolvimento de software para o parceiro pelo grupo & 0 \\
\hline Transferência de tecnologia desenvolvida pelo grupo para o parceiro & 1 \\
\hline Transferência de tecnologia desenvolvida pelo parceiro para o grupo & N.d. \\
\hline Atividades de consultoria técnica não contemplada nos demais tipos & N.d. \\
\hline $\begin{array}{l}\text { Fornecimento, pelo parceiro, de insumos materiais para as atividades de } \\
\text { pesquisa do grupo sem vinculação a um projeto específico de interesse } \\
\text { mútuo. }\end{array}$ & 0 \\
\hline $\begin{array}{l}\text { Fornecimento, pelo grupo, de insumos materiais para as atividades do } \\
\text { parceiro sem vinculação a um projeto específico de interesse mútuo. }\end{array}$ & 1 \\
\hline $\begin{array}{l}\text { Treinamento de pessoal do parceiro pelo grupo incluindo cursos e } \\
\text { treinamento "em serviço" }\end{array}$ & N.d. \\
\hline $\begin{array}{l}\text { Treinamento de pessoal do grupo pelo parceiro incluindo cursos e } \\
\text { treinamento "em serviço" }\end{array}$ & N.d. \\
\hline $\begin{array}{l}\text { Outros tipos predominantes de relacionamento que não se enquadrem } \\
\text { em nenhum dos anteriores (2) }\end{array}$ & 2. \\
\hline $\begin{array}{l}\text { Fonte: Elaboração própria, com base nos dados disponíveis na pesquisa } \\
\text { (1) Com base na classificação utilizada no Diretório Grupo de Pes } \\
\text { (2) Inclui teste e ensaio de peças. }\end{array}$ & q. \\
\hline
\end{tabular}

Quadro 7.10 - Quantidades de interações por natureza

Os grupos de pesquisa analisados apresentaram baixa frequência de interações com empresas do setor de máquinas e equipamentos nos últimos dois anos. O estudo de caso com os grupos de pesquisa identificou apenas dois exemplos de projetos conjuntos realizados entre esses grupos e empresas de máquinas-ferramenta do Estado de São Paulo nos últimos anos.

O primeiro exemplo de interação universidade-empresa refere-se à empresa com produção de máquinas-ferramenta que estabeleceu parceria nos 
anos 90 visando o desenvolvimento de máquina com tecnologia pouco difundida no mercado interno.

A parceria estabelecida com o grupo de pesquisa possibilitou à empresa o acesso de conhecimentos sobre a utilização de tecnologia High Speed Machine (HSM) para máquinas retificadoras. Para viabilizar a incorporação dessa tecnologia, a empresa investiu na criação de competências internas e na absorção dos conhecimentos ao seu ambiente fabril.

O segundo exemplo de interação universidade-empresa refere-se à empresa com produção de máquinas-ferramenta que também teve acesso a informações sobre a utilização de $H S M$ em máquinas de usinagem no início desta década.

De acordo com o grupo de pesquisa, a empresa não apresentava visibilidade sobre o potencial da tecnologia HSM para o seu desempenho tecnológico e industrial. Além disso, os resultados financeiros de curto prazo assumiram papel mais importante relativamente à pesquisa e desenvolvimento de tecnologias e a empresa não investiu o suficiente na criação de competências internas para desenvolver a tecnologia.

Como a empresa postergou as iniciativas e investimentos visando 0 desenvolvimento de competências internas, a interação entre essa empresa e o grupo de pesquisa não resultou em incorporação de conhecimentos.

Em grande medida, as interações com grupos de pesquisa são utilizados como forma de promover a atualização tecnológica de alguns modelos de máquinas comercializadas no mercado brasileiro. Entretanto, as fontes de atualização de produtos mais utilizadas entre os fabricantes de máquinas são os contatos com seus fornecedores e com os usuários das máquinas. Particularmente essa empresa com produção de máquinas-ferramenta tem desenvolvido interações com um dos grupos de pesquisa analisados, com fornecedores do mercado interno e com concorrentes do mercado interno e externo.

Os grupos visitados destacaram que as interações realizadas com empresas atingiram três resultados: formação de recursos humanos nas instituições de ensino superior, que é o principal resultado comentado pelos grupos de pesquisa; desenvolvimento ou acréscimo de conhecimentos na área de atuação dos grupos; e publicações acadêmicas. 
Em primeiro lugar, as parcerias realizadas com empresas de diferentes ramos industriais contribuíram para a formação e a experiência profissional de alunos matriculados nos cursos de graduação e pós-graduação das Instituições de Ensino Superior. Isso porque as atividades de pesquisa acadêmica associadas a pesquisa empírica acentuam o aprendizado de conhecimentos teóricos e o desenvolvimento de novas habilidades no processo de produção de máquinas entre os alunos.

Em segundo lugar, as interações entre os grupos de pesquisa e empresas resultaram em mudanças incrementais nas características das máquinas e ajudaram a ampliar os conhecimentos sobre tecnologias do processo de produção de máquinas-ferramenta. Entretanto, alguns grupos de pesquisa visitados destacaram que a transferência de conhecimentos novos é mais intensa dos grupos para as empresas fabricantes de máquinas do que o inverso.

A principal justificativa apontada para esse comportamento é que algumas empresas não aceitam compartilhar parte de suas informações sobre produtos ou processos com os grupos de pesquisa. Mesmo nos casos em que a empresa solicita apenas o teste de uma máquina ou tecnologia para o grupo, as empresas apresentam receio em fornecer informações sobre o projeto das máquinas para o grupo envolvido na parceria.

Em terceiro lugar, as interações entre os grupos de pesquisa e empresas de diferentes setores industriais contribuem para as publicações científicas na forma de periódicos, trabalhos de iniciação científica, dissertações e teses, e em menor grau, para a participação dos grupos em eventos setoriais. Para operacionalizar as atividades de pesquisa, os grupos também contam com a atuação de pesquisadores de áreas das engenharias. Esses pesquisadores, por sua vez, podem apresentar conhecimentos sobre etapas como projeto mecânico ou processos de fabricação.

Nesse cenário, mesmo que a interação com as empresas não apresente resultados esperados pelo grupo, a mobilização e troca de informações com pesquisadores de outras áreas é um fator importante para as publicações acadêmicas e a continuidade das pesquisas do grupo. 


\subsection{As dificuldades nas interações entre as empresas de máquinas e os grupos de pesquisa analisados}

A pesquisa empírica identificou que as empresas de máquinasferramenta do mercado interno apresentam interações com os grupos localizados no Estado de São Paulo. Além disso, as principais áreas envolvidas nas interações são as áreas de engenharia mecânica e engenharia de produção.

Considerando o tamanho do parque produtivo de máquinas e a infraestrutura de pesquisa científica no Estado de São Paulo, há poucos exemplos de interações no mercado interno e há baixa regularidade das iniciativas por parte das empresas.

As entrevistas e visitas realizadas junto aos grupos de pesquisa permitiram a identificação de cinco fatores que podem explicar o perfil de interações entre empresas e os grupos de pesquisa com atuação no ramo de máquinas.

O primeiro fator que pode explicar a baixa regularidade de interações entre empresas e grupos de pesquisas é que as empresas preferem utilizar os conhecimentos que já detém no seu ambiente de fábrica para lidar com problemas técnicos ou melhorar as características de seus produtos.

Considera-se que essa afirmação pode ser corroborada por uma característica estrutural do desenvolvimento do setor de máquinas no Brasil. De maneira geral, as estratégias visando à especialização dos conhecimentos em engenharia mecânica possibilitaram às empresas nacionais de máquinas 0 acúmulo de competências e de habilidades em projeto e produção de máquinas. A partir dos resultados da pesquisa empírica é possível constatar que há algumas especificidades nessas condições, dependendo do porte da empresa de máquina-ferramenta.

Nas empresas de máquinas de micro e pequeno porte, que desenvolvem produtos com tecnologias mais simples, as fontes para as alterações incrementais nas características dos produtos ou processos são o ambiente interno, a experiência dos funcionários e, em menor grau, as interações estabelecidas com os usuários das máquinas. 
Nas empresas de médio e grande porte, que fabricam máquinas com tecnologias relativamente mais complexas, as interações realizadas com usuários e fornecedores das máquinas exercem papel relativamente mais importante para o desenvolvimento e melhoria dos produtos. Além disso, aquelas interações possibilitam a ampliação de conhecimentos e competências no ambiente interno das empresas de máquinas.

Em ambos os grupos de empresas com produção de máquinas, as competências acumuladas internamente resultaram em condições próprias para lidar com problemas técnicos e adotar melhorias no processo de produção. Por conta dessa característica, frequentemente, as empresas consideram desnecessário o contato com instituições de pesquisa.

O segundo fator apontado como justificativa para o perfil de interações entre empresas e grupos está diretamente relacionado ao primeiro fator. De acordo com dois grupos de pesquisa analisados, há um distanciamento entre o que é pesquisado nas instituições públicas e privadas e o que é praticado entre as empresas de máquinas no Brasil.

O distanciamento entre a pesquisa científica e a produção pode indicar que as questões de interesse das empresas e dos grupos de pesquisa são diferentes ou que há dificuldade em conciliar os objetivos de ambos os grupos. Entretanto, o distanciamento entre pesquisa científica e produção também é atribuído ao desconhecimento, por parte das empresas, sobre a atuação dos grupos e eventuais contribuições das parcerias para o desenvolvimento e as melhorias das máquinas.

O terceiro fator apontado como justificativa para a baixa regularidade de interações entre empresas e grupos pesquisa é a incompatibilidade em relação ao tempo requerido por empresas e por grupos de pesquisa para a obtenção de resultados da pesquisa científica.

De maneira geral, os projetos de pesquisa apresentam resultados no médio e longo prazo. Isso porque a identificação de um problema de pesquisa e a realização das atividades científicas correlacionadas depende de fatores como a disponibilidade de recursos financeiros e a mobilização de pesquisadores de diferentes áreas de conhecimento.

As empresas com atuação no ramo de máquinas, por sua vez, trabalham com expectativa de curto prazo em relação aos resultados das 
pesquisas científicas. Em muitos casos, as empresas não podem esperar tais resultados porque isso implicaria, por exemplo, em queda das vendas ou perda de mercado para concorrentes.

$O$ quarto fator que influencia negativamente as iniciativas e contatos das empresas com os grupos de pesquisa é a incerteza em relação aos resultados da pesquisa científica. De acordo com três pesquisadores entrevistados, nem sempre a pesquisa científica resulta em ganhos econômicos de produtos e mercado para a empresa.

O quinto fator citado por grupos de pesquisa e empresas com produção de máquinas refere-se às exigências burocráticas para a realização de contratos de parceria e os custos envolvidos nas atividades de pesquisa.

De acordo com três grupos de pesquisa visitados, as exigências burocráticas podem inviabilizar ou desestimular as iniciativas de parceria das empresas com grupos de pesquisa, principalmente, entre as empresas de pequeno e médio porte. Para reduzir a burocracia na realização de pesquisa conjunta, há esforços por parte de alguns grupos visando as interações informais com empresas de outros ramos industriais.

Além disso, o mercado interno apresenta programas públicos visando o apoio financeiro de atividades inovativas e a redução dos custos das atividades de pesquisa conjunta para as empresas. Entretanto, de acordo os entrevistados (empresas e grupos de pesquisa), os órgãos e entidades responsáveis por esses programas impõem algumas condições irreais para as empresas de pequeno e médio porte interessadas no desenvolvimento de produtos.

O distanciamento entre pesquisa científica e tecnológica, a incompatibilidade de tempo, a incerteza em relação aos resultados econômicos e os custos e burocracia da pesquisa conjunta exercem influência sobre as iniciativas e parcerias entre empresas e grupos de pesquisa com atuação no ramo de máquinas e equipamentos. Entretanto, dois pesquisadores entrevistados a burocracia interna às empresas e a falta de visão para inovar.

O sexto fator que influencia as iniciativas e contatos das empresas de máquinas-ferramenta com os grupos de pesquisa é a característica do processo de produção praticado por empresas de máquinas-ferramenta no mercado interno. 
De maneira geral, as empresas nacionais que fabricam máquinasferramenta trabalham com escala de produção baixa, o que funciona como desestímulo para os investimentos em máquinas. Em muitos casos, as empresas procuram por grupos de pesquisa, principalmente, nos períodos em que o mercado não está aquecido. Entretanto, com a expectativa de consumo em baixa, os esforços e os gastos com parcerias são limitados.

Nos períodos em que ocorre o crescimento da demanda, grande parte das empresas prefere investir em aumento da escala de produção e não há tempo ou recursos para investir em pesquisas. As empresas preferem postergar os investimentos voltados à criação de competências e absorção de conhecimentos tecnológicos.

Outro fator importante é que alguns modelos de máquinas são modularizadas, isto é, são desenvolvidas em plataformas. Nesse cenário não há necessidade de interagir visando às mudanças de tecnologias porque é só procurar as opções de componentes e respectivos preços no mercado.

De acordo com o pesquisador de um grupo de pesquisa que não apresenta interações com o setor nacional de máquinas, as empresas nacionais de máquinas têm condições de atuar no processo de fabricação e em melhorias incrementais de seus produtos. Então esse fator poderia explicar 0 baixo índice de interações entre as empresas e os grupos de pesquisa.

Por outro lado, a área de projeto mecânico representa o principal gargalo para o desenvolvimento técnico do setor de máquinas do Brasil. A maior parte das empresas nacionais se especializou em adaptar modelos de máquinas antigos e não apresenta um departamento próprio de projeto. As empresas estrangeiras com atuação no Brasil, por sua vez, trazem os projetos da matriz.

Para o pesquisador, é necessário criar infraestrutura e apoio para estimular as pesquisas e o desenvolvimento da área de projeto mecânico entre as empresas nacionais de máquinas.

O próximo capítulo discute os conceitos de regime tecnológico, trajetórias tecnológicas e o arcabouço sobre Sistema Setorial de Inovação considerando as informações sobre o setor de máquinas-ferramenta do Brasil e os resultados da pesquisa empírica. 


\section{Capítulo 8 - Considerações sobre o setor de máquinas- ferramenta no Brasil}

Esse capítulo analisa as características do desenvolvimento competitivo e tecnológico do setor de máquinas-ferramenta, considerando as informações da revisão teórica e a discussão empírica da tese. O capítulo abrange três perspectivas tratadas na tese: desenvolvimento industrial; trajetórias e regime tecnológico; e Sistema Setorial de Inovação.

A primeira seção apresenta uma discussão sobre algumas das características estruturais do setor de máquinas-ferramenta do Brasil, que têm norteado as decisões sobre produção e desenvolvimento tecnológico.

A segunda seção discute as características do regime tecnológico do setor de máquinas-ferramenta do Brasil.

A terceira seção retoma a discussão sobre Sistema Setorial de Inovação, considerando informações obtidas na pesquisa empírica com empresas de máquinas-ferramenta e grupos de pesquisa do Estado de São Paulo.

\subsection{Desenvolvimento industrial e trajetórias tecnológicas do setor de máquinas-ferramenta no Brasil}

Desde o surgimento do setor de máquinas-ferramenta no século $\mathrm{XIX}$, o desenvolvimento e o desempenho das empresas de máquinas foram influenciados por escolhas entre trajetórias tecnológicas, que se difundiram de maneira distinta entre os países, como foi apresentado na revisão teórica da tese.

De maneira geral, critérios econômicos com a possibilidade de redução de custos da nova tecnologia e a possibilidade de economizar com a quantidade de mão de obra utilizada no processo produtivo são fatores importantes para a escolha de uma trajetória tecnológica a ser seguida. 
Além disso, as características da demanda e o ambiente institucional contribuem para a difusão inicial das tecnologias e possibilitaram que os conhecimentos fossem internalizados ao sistema econômico.

No Brasil, as características do ambiente institucional e da demanda também constituem fatores importantes para orientar a escolha entre as trajetórias tecnológicas da indústria. Entretanto, as trajetórias de desenvolvimento adotadas pelo setor nacional são distintas, relativamente aos outros países que atuam na produção de máquinas.

O ambiente institucional do Brasil apresenta um conjunto de atores, regras e políticas macroeconômicas ${ }^{65}$ que orientam o desenvolvimento produtivo e tecnológico do setor de máquinas-ferramenta.

A demanda nacional por máquinas, por sua vez, pode influenciar as pesquisas, o desenvolvimento e as melhorias das máquinas, influenciando as escolhas entre trajetórias tecnológicas distintas daquelas verificadas em outros países com produção no setor.

A demanda por máquinas é fortemente influenciada pelas expectativas em relação ao desempenho da economia. Nos períodos em que os setores industriais apresentam expectativa de queda em relação ao desempenho da economia nacional, haverá revisão de suas estratégias produtivas e queda da demanda por máquinas. Nos períodos que os setores industriais apresentam expectativa de crescimento em relação ao desempenho da economia, haverá aumento dos investimentos na aquisição de máquinas.

A dependência em relação a essa condição cíclica da economia implica que, ao direcionar a produção de máquinas para o atendimento de um único mercado (nacional), o desempenho industrial e os resultados econômicos das empresas estão mais sujeitos às condições daquele mercado.

Para lidar com a condição cíclica da demanda, as empresas produtoras de máquinas-ferramenta do Brasil apresentam um padrão de desenvolvimento produtivo que pode ser apontado como uma das causas da atual fragilidade no desempenho industrial e econômico do setor de máquinas-ferramenta.

\footnotetext{
65 A influência dos atores do ambiente institucional sobre o desenvolvimento do setor de máquinasferramenta será abordado na última seção deste capítulo, considerando a discussão sobre Sistema Setorial de Inovação.
} 
Até meados da década de 1970, as orientações de política econômica conduziam o setor de máquinas-ferramenta nacional a desenvolver sua estrutura industrial voltado para $\mathrm{o}$ atendimento da demanda do mercado interno.

As empresas com produção de máquinas-ferramenta fabricavam produtos com baixa complexidade tecnológica e contavam com incentivos fiscais e políticas de proteção ao setor nacional.

O desenvolvimento tecnológico do setor estava apoiado, principalmente, em importações de tecnologias provenientes de outros países.

As medidas protecionistas permitiram a formação e consolidação do setor de máquinas do Brasil. Isso porque as importações assumiam papel decisivo para a ampliação da capacidade produtiva e a modernização do parque produtivo de máquinas do mercado interno.

Entretanto, essas importações não incentivavam a criação e difusão de competências próprias entre empresas e demais atores com atividades no setor de máquinas.

Destaca-se que as importações repercutiam em baixa incorporação de conhecimentos tecnológicos voltados às características do sistema econômico nacional. Além disso, as importações associadas a medidas protecionistas funcionavam como um desestímulo ao desenvolvimento de competências entre as empresas do setor de máquinas e equipamentos.

A partir da década de 1970, a inserção de tecnologias de automação na produção das máquinas aumentou a velocidade da mudança técnica no interior das empresas e do setor de máquinas internacional.

No caso do setor de máquinas-ferramenta do Brasil, a primeira ruptura no padrão de desenvolvimento de tecnologias ocorreu somente a partir de meados dos anos de 1980.

No inicio da década de 1980, algumas empresas nacionais e multinacionais de grande porte começaram a incorporar tecnologias de automação, como controle numérico, a alguns modelos de máquinas.

Em grande medida, essas empresas utilizaram as competências desenvolvidas num ambiente de mercado protegido e investiram para ampliaram essas competência e utilizar as tecnologias de automação. 
Como resultado, destaca-se o aprendizado e a melhoria contínua das linhas de máquinas possibilitaram novo padrão de mudança técnica, a partir de conhecimentos da área de engenharia mecânica e de sua combinação com conhecimentos da microeletrônica.

Por outro lado, grande parte das empresas do setor não reunia as competências necessárias para aprender aqueles conhecimentos e incorporálos ao seu ambiente de produção.

Além disso, alguns fatores estruturais impossibilitaram a difusão daquelas tecnologias para as demais empresas do setor de máquinasferramenta com atuação no Brasil.

A instabilidade econômica e as políticas macroeconômicas restringiam o nível de investimento da indústria de transformação. $E$ as variações do nível de investimento, por sua vez, determinavam queda da demanda por máquinas nacionais.

Naquele cenário, o setor de máquinas não apresentava escala suficiente para fabricar linhas de máquinas de forma a diluir os investimentos com a aquisição das novas tecnologias.

Para lidar com essa situação, muitas empresas com produção de máquinas e equipamentos adotaram a estratégia de diversificação dos modelos de máquinas dentro de uma mesma linha de produtos.

A diversificação dos modelos de máquinas associada à baixa escala de produção são características vigentes ainda hoje no setor de máquinasferramenta nacional.

As empresas nacionais utilizam a diversificação de produtos como forma de atender às especificidades nos pedidos dos clientes e, principalmente, para garantir os ganhos econômicos e amenizar os efeitos sofridos por oscilações da demanda do mercado interno ${ }^{66}$.

Os efeitos de uma eventual queda da demanda de alguns modelos de produtos, por exemplo, podem ser amenizados pela venda de modelos de máquinas similares, que apresentam diferenças em algumas especificações.

${ }^{66}$ Outra característica vigente no setor de máquinas nacional é a elevada verticalização da produção. 
A abertura da economia e as políticas macroeconômicas adotadas a partir da década de 1990 ajudaram a reforçar as características estruturais do desenvolvimento do setor de máquinas-ferramenta nacional.

Nesse período, empresas de diferentes setores realizaram a revisão de suas estratégias industriais e de desenvolvimento tecnológico como forma de se adequar às condições macroeconômicas e à abertura do mercado interno ao comércio exterior.

Em especial, algumas empresas de máquinas-ferramenta de médio e grande porte promoveram a atualização tecnológica por meio de parcerias e contratos formais estabelecidos com empresas de máquinas provenientes de outros países.

A partir daqueles acordos, essas empresas puderam acessar informações sobre tecnologias de produto e processo. E esse fator permitiu a atualização do parque produtivo brasileiro de uma maneira geral.

Esse processo foi restrito àquele grupo de empresas de grande e médio porte. Muitas empresas de micro e pequeno porte que atuavam no setor de máquinas-ferramenta não apresentavam condições para realizar a racionalização de seus processos produtivos e investimentos em atualização tecnológica.

A instabilidade da demanda do mercado interno e as alterações da política macroeconômica dificultavam a atuação de ambos os grupos de empresas do setor de máquinas-ferramenta no mercado interno.

As estratégias voltadas à incorporação de tecnologias no longo prazo, frequentemente, eram substituídas por mecanismos voltados à manutenção das receitas de vendas no curto prazo.

$\mathrm{Na}$ ultima década deste século, o setor de máquinas e equipamentos nacional apresentou algumas mudanças na sua estrutura industrial e em seu desempenho no comércio internacional de máquinas-ferramenta.

A estrutura industrial do setor apresentou queda do número de estabelecimentos e queda do número de emprego no período entre 2005 e 2009. Esses resultados, por sua vez, podem ser atribuídos à queda da produção nacional de máquinas e equipamentos.

Destaca-se que como o segmento de máquinas ferramenta do Brasil é formado, principalmente, por empresas de pequeno porte, as variações da 
demanda do mercado interno no período 2007-2009 exerceram forte pressão sobre a produção e a sobrevivência daquelas empresas estabelecidas no mercado brasileiro.

As empresas de médio e grande porte, por sua vez, também têm enfrentado dificuldades para ampliar a produção de máquinas-ferramenta, seja no mercado interno, regional (América Latina) ou internacional.

A partir dos anos 90, a indústria nacional de máquinas-ferramenta passou a enfrentar a concorrência com países do leste asiático, em especial, China e Taiwan, que fabricam máquinas-ferramenta com diferentes níveis tecnológicos.

A crise econômica mundial, a partir de 2008, acentuou as diferenças da dinâmica competitiva e tecnológica do setor entre os países. Como analisado no capítulo 5, no período entre os anos de 2007 e 2009, a queda da demanda mundial por máquinas repercutiu no desempenho do setor de máquinasferramenta de todos os países com atuação nesse setor.

A Alemanha, o Japão e a China apresentam elevada participação nas exportações e importações de máquinas-ferramenta para trabalhar metal ou outros materiais, com ou sem remoção de material.

Mesmo com a queda da demanda mundial de máquinas, destaca-se que a Alemanha e o Japão mantém sua posição entre os principais fabricantes e exportadores de máquinas-ferramenta.

No período pós-crise, o setor de máquinas daqueles países conseguiu recuperar seu desempenho de maneira mais rápida, relativamente aos demais países com produção de máquinas-ferramenta.

Outros países que também apresentam participação importante na produção e comércio de máquinas, em especial, os Estados Unidos e a Itália, perderam sua posição para os países do leste asiático.

O setor de máquinas-ferramenta do Brasil, por sua vez, é um dos principais importadores mundiais de máquinas-ferramenta, em especial, nas categorias de máquinas que apresentam maior complexidade tecnológica.

Os dados sobre comércio internacional de máquinas-ferramenta por tipos de produtos e países também podem ilustrar algumas diferenças na escolha entre trajetórias tecnológicas do setor de máquinas-ferramenta entre os países. 
A Alemanha e o Japão apresentam importante participação no comércio exterior de máquinas, especialmente, nos ramos de máquinas para trabalhar metais, com ou sem formação de cavaco. As máquinas fabricadas por aqueles países incluem desde modelos com tecnologias automáticas até sistemas de máquinas com maior complexidade tecnológica.

Em grande medida, os resultados no comércio internacional de máquinas podem ser atribuídos às competências desenvolvidas pelo setor de máquinas-ferramenta daqueles países desde o século passado.

Além disso, os atores do Sistema Setorial de Inovação de máquinasferramenta, em especial, o governo e os institutos de pesquisa, possibilitaram o aprendizado, incorporação e difusão dos conhecimentos no sistema econômico.

Os países do leste asiático, por sua vez, apresentam participação crescente nos dados de comércio internacional de todas as categorias de máquinas-ferramenta.

O desempenho daqueles países na produção e no comércio internacional de máquinas-ferramenta, mesmo no período de queda da demanda internacional, pode ser atribuído ao seu mercado consumidor.

A existência de um grande mercado consumidor nacional possibilita que os efeitos de variações da demanda internacional sejam amenizados pela venda de máquinas para o mercado nacional.

A escala de produção também é um fator importante para 0 desempenho industrial das empresas de máquinas-ferramenta porque ajuda a reduzir os custos associados à $P \& D$ e a difundir os conhecimentos dentro do setor produtivo.

A existência de um amplo mercado consumidor na China, por exemplo, possibilita a produção de máquina-ferramenta em grande escala. Como o setor de máquinas-ferramenta da China apresenta elevada escala de produção de máquinas, as tecnologias podem ser desenvolvidas, difundidas e internalizadas ao cenário econômico.

Em relação ao setor de máquinas-ferramenta do Brasil, destaca-se a pequena participação do setor nos dados de exportação mundial de máquinas, mesmo nas categorias de produtos em que o país apresenta forte 
especialização. Nas categorias de produtos com tecnologia mais complexa, por sua vez, o setor nacional se tornou um dos principais importadores mundiais.

O desenvolvimento técnico do setor de máquinas não é proveniente apenas de tecnologias de automação, que são incorporadas às máquinas através da aquisição de componentes eletrônicos. O avanço nos conhecimentos em outras áreas que permeiam o desenvolvimento técnico das máquinas-ferramenta, como a engenharia de materiais e engenharia de produção, também contribui para o desenvolvimento das máquinas-ferramenta no cenário internacional.

A maior parte das empresas com atuação no setor de máquinasferramenta do Brasil não tem conseguido aproveitar e criar oportunidades diante das trajetórias colocadas para o desenvolvimento técnico das máquinas. E esse fator pode comprometer as condições para o atendimento da demanda, inclusive no mercado interno.

Vale notar que há algumas empresas de máquinas-ferramenta de médio e grande porte que não se enquadram na situação anterior. Essas empresas de máquinas-ferramenta apresentam competências que foram acumuladas ao longo do tempo. Essas competências, por sua vez, possibilitaram a identificação de novas trajetórias tecnológicas importantes para o desenvolvimento das máquinas e o desempenho industrial.

Nesse cenário, o pequeno grupo de empresas de médio e grande porte tem apresentado esforços para ampliar o acesso aos conhecimentos das trajetórias disponíveis para o setor de máquinas. Para viabilizar o acesso a essas tecnologias, as empresas realizam parcerias com empresas e instituições de pesquisa, ou compram empresas estrangeiras que detém conhecimentos sobre tecnologias de produto e processo.

Apesar dos esforços e das competências já acumuladas ao longo do tempo, essas empresas apresentam dificuldades para integrar esses conhecimentos ao seu conjunto de competências e fabricar produtos comercialmente viáveis.

Além disso, em seus esforços visando o desempenho econômico, aquelas empresas se deparam com trade off entre a produção de máquinas com tecnologias mais simples e a produção de máquinas com tecnologias mais complexas. 
A produção de máquinas com tecnologias mais simples é viabilizada, principalmente, pelo estoque de conhecimentos que essas empresas já dominam, e que estão difundidos entre as empresas concorrentes e outros ramos industriais de máquinas.

Como o principal fator de competitividade daquelas máquinas é o preço, as vantagens competitivas dessas empresas são transitórias.

A produção de máquinas com tecnologia mais complexa, por sua vez, está apoiada em interações que as empresas realizam com fornecedores e outros atores da cadeia de máquinas.

De maneira geral, esses conhecimentos não estão amplamente difundidos entre as empresas com produção de máquinas-ferramenta. E por esse motivo, as interações com outros atores podem se importantes para 0 desenvolvimento e melhoria das máquinas.

Como o principal fator de competitividade desses produtos é a qualidade e desempenho na realização de tarefas, as vantagens competitivas das empresas podem ser mais duradouras. Entretanto, a criação dessas vantagens demanda mais esforços em termos de tempo e dinheiro investido para ao desenvolvimento daqueles produtos.

Com base análise realizada até aqui, é possível afirmar que as condições macroeconômicas do país exercem papel importante na fase inicial da escolha da trajetória tecnológica do setor de máquinas-ferramenta através dos países.

O principal elemento que respalda esse argumento é que a condição macroeconômica influencia a demanda por máquinas. E a demanda nacional por máquinas, por sua vez, pode dificultar ou acelerar o processo de difusão das tecnologias e a internalização dos conhecimentos no sistema econômico.

Por outro lado, as escolhas produtivas e as características do ambiente tecnológico em que as empresas atuam, assim como estrutura do Sistema Setorial de Inovação podem exercer maior peso para o desenvolvimento tecnológico de um setor do que a condição macroeconômica nacional.

A próxima subseção analisa as características do regime tecnológico do setor de máquinas-ferramenta no Brasil. 


\subsection{O regime tecnológico do setor de máquinas-ferramenta do Brasil}

O conceito de regime tecnológico refere-se às características do ambiente tecnológico colocado recentemente para o desenvolvimento do setor de máquinas-ferramenta do Brasil.

O regime tecnológico de cada setor industrial reunirá diferentes estratégias e condições relacionadas ao processo de criação, incorporação e difusão de tecnologias realizadas por empresas e setores.

De maneira geral, as estratégias adotadas por empresas do setor de máquinas-ferramenta são condicionadas pelas condições macroeconômicas do mercado de destino das máquinas.

Como ressaltado na seção anterior, o principal mecanismo utilizado pelas empresas de máquinas-ferramenta no Brasil para amenizar os efeitos dessas condições macroeconômicas sobre as variações da demanda no mercado interno é a diversificação dos modelos de máquinas atrelada à especialização dos conhecimentos tecnológicos.

A estratégia utilizada pelo setor de máquinas-ferramenta do Brasil refletiu nas condições de seu ambiente tecnológico e em seu dinamismo competitivo e tecnológico recente.

O desenvolvimento tecnológico do setor de máquinas-ferramenta do Brasil está apoiado, principalmente, em conhecimento interno da área de engenharia mecânica. Grande parte desses conhecimentos internos das empresas de máquinas-ferramenta pode ser classificada como tácitos, porque são construídos a partir da experiência e das habilidades dos funcionários da área de produção das máquinas ${ }^{67}$. Como as empresas de máquinasferramenta incorporam conhecimentos e desenvolvem competências numa mesma base, o setor de máquinas-ferramenta nacional apresenta elevada especialização nessa área de conhecimento.

Considera-se que a elevada especialização de conhecimentos pode apresentar efeitos positivos e negativos para o desenvolvimento tecnológico do setor de máquinas-ferramenta do Brasil.

\footnotetext{
${ }^{67}$ A formação e atualização dos funcionários também têm assumido papel importante, principalmente, entre as empresas de médio e grande porte.
} 
O efeito positivo da especialização dos conhecimentos é a elevada cumulatividade dos conhecimentos internos às empresas e internos ao setor.

As informações acumuladas internamente são utilizadas na adaptação e melhorias dos modelos de máquinas comercializadas no mercado interno e na resolução de problemas técnicos que podem comprometer o desempenho da máquina.

A elevada cumulatividade dos conhecimentos do setor de máquinasferramenta possibilita o desenvolvimento de variedade de modelos de máquinas dentro de uma mesma linha de máquinas.

A diversificação de produtos é um fator importante para o desempenho do setor de máquinas-ferramenta do Brasil no mercado interno porque garante participação das empresas em uma fatia maior do mercado consumidor. Além disso, as empresas de máquinas podem atender às especificidades da demanda por máquinas especiais.

Entretanto, 0 fato de as empresas de máquinas-ferramenta apresentarem competências para adaptar os modelos de máquinas às necessidades do usuário pode ser importante para a sua competitividade, mas essa competitividade é transitória. Há alguns fatores que corroboram essa afirmação.

Em primeiro lugar, os conhecimentos tecnológicos incorporados às máquinas são provenientes da área mecânica e apresentam caráter pervasivo, isto é, estão difundidos para outras áreas de conhecimento. Isso significa que esses conhecimentos podem ser incorporados por empresas nacionais e internacionais de máquinas-ferramenta.

Neste cenário, mesmo os produtos com adaptações podem ser considerados commodities e podem ser copiados por concorrentes das empresas nacionais de máquinas-ferramenta.

Em segundo lugar, as melhorias incrementais da máquina não garantem grandes ganhos de mercado para as empresas de máquinas-ferramenta por conta da variável preço do produto.

O principal fator de competitividade das máquinas-ferramenta que incorporam melhorias e são baseadas em conhecimentos de engenharia mecânica é o preço do produto final. 
Em muitos casos, as empresas fabricantes de máquinas não podem cobrar o preço de mercado que cubra os custos com aquelas modificações no projeto do produto. Isso porque os clientes podem procurar outra empresa de máquina-ferramenta que realize as alterações do produto a um preço mais acessível.

Essa questão se tornou decisiva para a competitividade das empresas de máquinas-ferramenta do Brasil, principalmente após a inserção de empresas de máquinas provenientes da China no mercado nacional.

Por conta desses fatores, pode-se ressaltar que a especialização dos conhecimentos e a diversificação dos produtos não têm sido suficiente para garantir a competitividade das empresas de máquinas-ferramenta do Brasil no mercado interno e externo.

O efeito negativo da especialização do conhecimento na base mecânica refere-se aos efeitos de trancamento (lock in) da trajetória tecnológica do setor de máquinas-ferramenta no longo prazo.

Em grande medida, as empresas de máquinas-ferramenta de pequeno porte não reúnem as competências e as experiências necessárias para acompanhar outras trajetórias tecnológicas e avanços em outras áreas da ciência. Por esse motivo, aquelas empresas podem apresentar dificuldades para identificar o potencial dos avanços da ciência básica e do conhecimento aplicado para o desenvolvimento de produtos.

Entre as empresas de máquinas de médio e grande porte, por sua vez, mesmo que o potencial desses conhecimentos seja visível, algumas empresas podem apresentar dificuldade para incorporar, internalizar e difundir esses conhecimentos no seu parque produtivo. Nesses casos, o custo e o tempo requeridos para a aquisição e aprendizado de uma nova tecnologia e a incerteza em relação aos resultados dessa escolha podem limitar o desenvolvimento e incorporação das tecnologias às máquinas. Além disso, esse conjunto de características influencia as condições de oportunidade para o desenvolvimento de tecnologias no longo prazo.

De maneira geral, a especialização dos conhecimentos tecnológicos pode ser apontada como determinantes da baixa condição de oportunidade do setor de máquinas-ferramenta nacional. 
Outro fator importante é que as empresas de máquinas-ferramenta incorporam conhecimentos da área mecânica e conseguem gerar economias externas que são importantes para o atendimento de nichos de mercado. Como uma parte dos conhecimentos acumulados ao longo do tempo apresenta caráter tácito, as informações utilizadas na melhoria dos tipos de máquinas podem ser difundidas através da troca de experiência entre os funcionários no interior das empresas ou entre os ramos industriais de máquinas-ferramenta.

As empresas com produção de máquinas-ferramenta que atuam na área de usinagem, por exemplo, conhecem bem os processos de torneamento, retificação ou fresamento, mesmo que esses três processos não sejam desenvolvidos internamente.

A difusão de conhecimentos entre aquelas empresas, por sua vez, implica em baixa apropriabilidade (ou poucas condições) para proteger os conhecimentos do acesso de empresas concorrentes. Além disso, a baixa apropriabilidade dos conhecimentos do setor determina que as economias externas geradas a partir da alta cumulatividade também sejam responsáveis por vantagens competitivas transitórias.

Um elemento adicional que ajuda a explicar a dinâmica tecnológica do setor de máquinas-ferramenta do Brasil é a elevada participação de produtos provenientes de outros países no mercado brasileiro.

Uma parte das máquinas com maior complexidade tecnológica utilizadas no mercado nacional é adquirida através da importação. Esse comportamento pode indicar que o setor produtivo está postergando suas estratégias visando à criação e difusão de competências internas às empresas e internas ao sistema econômico.

A próxima seção apresenta a análise sobre a dinâmica das interações entre empresas fabricantes de máquinas-ferramenta e os grupos de pesquisa com atuação no setor, considerando essas características do regime tecnológico e a noção de Sistema Setorial de Inovação. 


\subsection{Elementos do Sistema Setorial de Inovação de máquinas-ferramenta no Brasil}

O Sistema Setorial de Inovação de máquinas-ferramenta abrange o conhecimento-base; os atores e redes; e as instituições que possibilitam a criação, incorporação e difusão de conhecimentos internos às empresas e aos ramos industriais de máquinas-ferramenta.

Considera-se que as empresas apresentam papel importante para o atendimento da demanda nacional de máquinas e podem contribuir para a produtividade da indústria de transformação e para a qualidade dos produtos fabricados no mercado interno. Entretanto o desempenho industrial e tecnológico das empresas do setor de máquinas-ferramenta está limitado pelas características do regime tecnológico discutido na seção anterior.

As empresas de máquinas-ferramenta de médio e grande porte já vislumbraram a limitação imposta pelo regime tecnológico para o seu desenvolvimento industrial e técnico. Para viabilizar o aprendizado e a incorporação de informações provenientes de outras áreas e promover a atualização tecnológica, essas empresas de máquinas-ferramenta têm ampliado seus esforços para construir interações e parcerias com empresas e instituições no mercado interno e externo.

Desse modo, pode-se destacar que aquele grupo de empresas máquinas-ferramenta apresenta uma tendência para desenvolver e fortalecer interações entre as empresas e instituições de diferentes ramos industriais.

A partir dos resultados da análise empírica, é possível afirmar que o setor de máquina-ferramenta nacional apresenta um padrão de interações para o aprendizado e incorporação de conhecimentos tecnológicos.

No mercado externo, as principais fontes de atualização tecnológica das empresas de grande porte é a participação em feiras internacionais do setor, a realização de parcerias com empresas estrangeiras de grande porte ou a compra de empresas de pequeno porte e capital estrangeiro que atuam no ramo de máquinas. No mercado interno, as principais fontes de atualização tecnológica das empresas nacionais de máquinas-ferramenta são as interações realizadas com fornecedores de componentes eletrônicos e com os usuários das máquinas. 
É importante registrar que essas duas formas de atualização tecnológica são realizadas por um pequeno grupo de empresas de máquinas-ferramenta que atua no mercado nacional há algumas décadas.

As parcerias realizadas por essas empresas contribuem para 0 desenvolvimento ou melhoria dos produtos e influenciam a criação de novas competências internas. Além disso, essas empresas apresentam maior capacidade de inovação, relativamente às demais empresas com atuação no setor de máquinas-ferramenta.

Os conhecimentos sobre as características dos materiais usados na produção das máquinas ou informações da área de engenharia elétrica, por exemplo, não são amplamente difundidos entre as empresas de máquinasferramenta. Esse fator é importante para o desempenho daquelas empresas porque eventuais modificações na trajetória de desenvolvimento daqueles insumos - por meio de uma nova combinação de metais ou através da eliminação de materiais, por exemplo - podem repercutir em alterações na forma de produzir as máquinas e influenciar o desempenho dos segmentos produtores das máquinas-ferramenta.

Como resultado dessas interações, destaca-se o fornecimento de máquinas e tecnologias para empresas de vários portes e níveis de intensidade tecnológica; e o desenvolvimento de competências de produto e processos que podem se tornar endógenos ao sistema de produção das máquinas.

Essa condição reforça a necessidade de criar vínculos com grupos de pesquisa que desenvolvem projetos relacionados ao setor de máquinasferramenta e que podem contribuir para a incorporação de conhecimentos de outras áreas da ciência.

A pesquisa empírica constatou que, há baixa regularidade de interações entre as empresas de máquinas-ferramenta e grupos de pesquisa com unidades localizadas no Estado de São Paulo

De acordo com as informações apresentadas no capítulo anterior, os principais fatores levantados pelas empresas de máquinas-ferramenta para justificar esse comportamento são o custo, a burocracia e o tempo.

Em primeiro lugar, as empresas destacam que o investimento para desenvolver a parceria e operacionalizar as atividades estipuladas no projeto é 
elevado. Em muitos casos, as condições de financiamento disponíveis no mercado não cobrem as condições das empresas de micro e pequeno porte.

Em segundo lugar, as empresas destacam que a burocracia e a quantidade de documentos exigidos dificulta a operacionalização da pesquisa.

Em terceiro lugar, o tempo demandado desde a fase de elaboração do projeto de pesquisa conjunta até a apropriação dos resultados finais é alto e as empresas precisam arcar com os riscos e a incerteza em relação aos resultados esperados.

A partir da análise das informações setoriais e empíricas é possível afirmar que a baixa integração entre empresas e grupos de pesquisa pode ser atribuída muito mais às características dos produtos e às competências internas que as empresas de máquinas-ferramenta detêm.

Em grande medida, como a maioria das empresas de máquinasferramenta produz máquinas com tecnologias relativamente simples, que não exigem conhecimentos científicos ou tecnológicos complexos, essas empresas não sentem necessidade de realizar parcerias com grupos de pesquisa. De acordo com a pesquisa empírica, as empresas de máquinas destacaram que não investem no aprendizado de novas tecnologias porque não há demanda por máquinas com essas tecnologias.

É possível analisar esse argumento sobre o desenvolvimento de tecnologias por empresas de máquinas-ferramenta do Brasil considerando a tipologia de Pavitt (1984).

Ao contrário do que é evidenciado na tipologia de Pavitt (1984) sobre o setor de fornecedores especializados, pode-se destacar que o desenvolvimento de tecnologias do setor de máquinas do Brasil é muito mais dependente da demanda do mercado interno e cada vez menos fornecedor de novas tecnologias (ou conhecimentos) para outros segmentos da indústria. Ou seja, o setor não empurra os conhecimentos para os usuários, mas é empurrado pelas especificações e exigências da demanda.

A 'dependência' em relação às características da demanda do mercado interno, por sua vez, pode repercutir negativamente no desenvolvimento de tecnologias das empresas brasileiras, relativamente ao padrão de desenvolvimento tecnológico verificado no cenário mundial. 
Os investimentos na aquisição de novas tecnologias por empresas de máquinas estão condicionados à existência de uma demanda por aquelas tecnologias. Esse argumento justificaria a reposta de algumas empresas de máquinas-ferramenta analisadas na pesquisa empírica ${ }^{68}$.

Mas o que se verifica através dos dados de comércio internacional de máquinas, por categoria de produtos, é que o mercado brasileiro apresenta demanda por tecnologias mais complexas. $\mathrm{E}$ a demanda por essas tecnologias é atendida por empresas estrangeiras.

A demanda do mercado interno pode apresentar papel importante para o nível de investimentos realizados por empresas de máquinas-ferramenta do Brasil, como foi apontado na primeira seção. Por outro lado, a característica da demanda nacional por máquinas não pode ser considerada determinante dos poucos esforços das empresas fabricantes de máquinas visando o aprendizado de tecnologias.

Apesar dessas características do desenvolvimento de tecnologias no setor máquinas-ferramenta, é importante relembrar que as empresas também detêm competências importantes para atender às especificações do mercado interno.

Outro elemento já discutido na literatura setorial e que pode ajudar a compreender a dinâmica do setor de máquinas-ferramenta é a idéia de descolamento entre as necessidades do parque produtivo brasileiro (consumo) e a oferta de máquinas e tecnologias por empresas de máquinas do mercado interno (Resende, 1999).

A ideia de descolamento considera que um dos principais efeitos da abertura comercial na década de 1990 para o setor de máquinas foi o crescimento do consumo doméstico em proporção relativamente maior ao aumento da produção local.

De maneira geral, o descolamento da produção nacional de máquinas pode ser atribuído às características macroeconômicas, às condições facilitadas para a compra de máquinas do exterior e ao alto preço do produto do mercado interno. A partir da pesquisa empírica da tese, considera-se que 0 descolamento entre oferta do setor de máquinas-ferramenta do Brasil e 
necessidades tecnológicas do mercado interno pode ser abordado sob outro ponto de vista.

Os conhecimentos tecnológicos sobre máquinas-ferramenta desenvolvidos mundialmente apresentam elevada convergência com outras áreas da ciência. Os avanços além da base de conhecimentos em mecânica, por exemplo, têm incorporado informações provenientes de outras áreas. $\mathrm{E}$ isso provocou o esgotamento do 'ciclo de vida' das tecnologias mais simples.

Para lidar com essa nova situação, é necessária a formação e atualização de competências nessas áreas. Entretanto, salvo algumas exceções, o mercado interno de máquinas mantém o desenvolvimento de seus projetos com base em conhecimentos tecnológicos que são difundidos entre os ramos industriais de máquinas através países.

Essa discussão reforça a importância dos Institutos e grupos de pesquisa para o desenvolvimento e o desempenho do setor de máquinasferramenta nacional. A análise empírica da tese identificou que, na década de 2000, apenas duas empresas estabeleceram interações com grupos de pesquisa.

De acordo com alguns pesquisadores, a baixa frequência de interações entre empresas e instituições de pesquisa não podem ser explicados por fatores econômicos, como os custos dos projetos. Isso porque, em muitos casos, as empresas podem recorrer ao financiamento de recursos no longo prazo.

Com base na análise setorial e empírica, destaca-se que 0 distanciamento entre as empresas com produção de máquinas-ferramenta e a pesquisa científica podem ser atribuídos à especialização do conhecimento das empresas de máquinas-ferramenta na base mecânica.

A baixa percepção das empresas de máquinas-ferramenta do mercado interno em relação ao potencial de algumas trajetórias tecnológicas e as estratégias industriais adotadas nas últimas décadas dificultam a apropriação e difusão desses conhecimentos pelo setor de máquinas-ferramenta do Brasil. Esse fenômeno é o oposto da condição verificada no desenvolvimento do setor de máquinas-ferramenta da Alemanha, Japão e EUA.

De um lado, a demanda interna e atuação do Estado possibilitaram a difusão inicial das mudanças técnicas entre as empresas de máquinas 
daqueles países. De outro lado, a infraestrutura científica e tecnológica, em parceria com a indústria, possibilitou a exploração dos conhecimentos provenientes das trajetórias selecionadas e viabilizou a incorporação daqueles conhecimentos ao sistema econômico nacional.

Com base na discussão realizada no capítulo 4, sobre os Sistemas Setoriais de Inovação tradicional e emergentes, destaca-se que o setor de máquinas-ferramenta do Brasil aproxima-se mais do modelo tradicional, e menos do modelo emergente.

A partir dos resultados da pesquisa empírica sobre empresas com produção de máquinas-ferramenta e as interações com instituições de pesquisa, ambos do Estado de São Paulo, é possível distinguir quatro diferenças em relação ao Sistema Setorial tradicional.

Em primeiro lugar, as formas de ligação externa para a amostra de empresas de máquinas e instituições de pesquisa são mais instáveis por conta do peso que a demanda interna exerce sobre as estratégias produtivas e tecnológicas das empresas de máquinas-ferramenta.

Em segundo lugar, o escopo geográfico do setor de máquinasferramenta é nacional, o que significa que a região em que os agentes atuam não exerce influência sobre o perfil e os resultados do Sistema Setorial de Inovação de máquinas.

Em terceiro lugar, o conhecimento-base das empresas com produção de máquinas-ferramenta é mais tácito, porque foi construído a partir de experiências dos funcionários. Além disso, esses funcionários exercem papel importante no projeto e melhorias técnicas das máquinas.

O último elemento do setor de máquinas-ferramenta é a barreira à entrada de novas empresas. Os segmentos de máquinas-ferramenta analisados na pesquisa empírica apresentam baixa barreira à entrada de novas empresas porque os conhecimentos utilizados na construção e melhoria das máquinas estão difundidos entre os ramos industriais.

O quadro 8.1 revisa as características do Sistema Setorial de Inovação tradicional e emergente; e apresenta as características do Sistema Setorial de Inovação de máquinas-ferramenta no Brasil. 


\begin{tabular}{|c|c|c|c|}
\hline Elementos & $\begin{array}{l}\text { Sistema Setorial } \\
\text { tradicional }\end{array}$ & $\begin{array}{l}\text { Sistema Setorial } \\
\text { Emergentes }\end{array}$ & $\begin{array}{c}\text { Sistema Setorial de } \\
\text { Inovação de máquinas- } \\
\text { ferramenta no Brasil }\end{array}$ \\
\hline $\begin{array}{l}\text { Forma de ligação } \\
\text { externa }\end{array}$ & Limitada, estável & Aberta, flexível & $\begin{array}{c}\text { Limitada e instável } \\
\text { (depende da perspectiva } \\
\text { sobre crescimento da } \\
\text { demanda) }\end{array}$ \\
\hline Escopo geográfico & Regional e nacional & Regional e internacional & Nacional \\
\hline Base tecnológica & Mecânica & Intensiva em informação & $\begin{array}{c}\text { Mecânica (pouco } \\
\text { eletrônica, depende da } \\
\text { categoria de produtos); }\end{array}$ \\
\hline $\begin{array}{l}\text { Desenvolvimento } \\
\text { de produto }\end{array}$ & Incremental & $\begin{array}{l}\text { Incremental e } \\
\text { sistemático }\end{array}$ & Incremental \\
\hline Relações de troca & $\begin{array}{c}\text { Produtores ligados com } \\
\text { usuários }\end{array}$ & $\begin{array}{l}\text { Parcerias de } \\
\text { produtores, usuários, } \\
\text { centros de pesquisa }\end{array}$ & $\begin{array}{l}\text { Usuários e fornecedores } \\
\text { (eletrônica) exercem papel } \\
\text { mais importante para o } \\
\text { desenvolvimento do setor }\end{array}$ \\
\hline Conhecimento-base & Tácito & Tácito e codificado & $\begin{array}{c}\text { Muito tácito, depende de } \\
\text { experiências dos } \\
\text { funcionários das empresas }\end{array}$ \\
\hline Forma corporativa & Individual, família & $\begin{array}{l}\text { Variado: interno e } \\
\text { externo }\end{array}$ & Individual, familiar \\
\hline $\begin{array}{l}\text { Organização de } \\
\text { trabalho }\end{array}$ & $\begin{array}{c}\text { Colaboração interna } \\
\text { informal }\end{array}$ & $\begin{array}{c}\text { Individual: grupos } \\
\text { corporativos (limitada a } \\
\text { multinacional) }\end{array}$ & $\begin{array}{c}\text { Colaboração interna } \\
\text { informal }\end{array}$ \\
\hline Entrantes & $\begin{array}{c}\text { Moderada barreira à } \\
\text { entrada }\end{array}$ & $\begin{array}{l}\text { Cooperação externa e } \\
\text { formalizada }\end{array}$ & $\begin{array}{l}\text { Baixa barreira à entrada } \\
\text { (depende do tipo de } \\
\text { produto fabricado) }\end{array}$ \\
\hline Demanda & Cíclica & $\begin{array}{c}\text { Alta barreira à entrada } \\
\text { inovação }\end{array}$ & $\begin{array}{l}\text { Cíclica (mais estável para } \\
\text { bens seriados, de baixo } \\
\text { conteúdo tecnológico) }\end{array}$ \\
\hline Política & Setorial, nacional & Cíclica & Setorial \\
\hline
\end{tabular}

Fonte: Elaboração própria, com informações da pesquisa setorial e empírica. Quadro adaptado de Wengel \& Shapira (2001).

Quadro 8.1 - Sistema Setorial de Inovação de máquinas-ferramenta: o caso do setor de máquinas-ferramenta do Brasil

Com base na análise apresentada nos capítulos de revisão teórica e de discussão empírica, o próximo capítulo apresenta a conclusão do trabalho. 


\section{Conclusão}

Os conceitos de paradigma tecnológico, trajetórias e regime tecnológico podem trazer importantes contribuições para a discussão sobre o desempenho tecnológico entre as economias industriais recentes.

Considera-se que o desenvolvimento industrial e tecnológico dos setores industriais é influenciado por escolhas realizadas pelas empresas entre diferentes trajetórias tecnológicas dentro do paradigma tecnológico.

As trajetórias tecnológicas orientam 0 processo de produção e a mudança técnica entre os setores. Além disso, essas trajetórias apresentam características específicas entre os países e entre um mesmo setor industrial através dos países.

Esses dois comportamentos são atribuído às características do ambiente de seleção em que ocorre a criação e difusão inicial de conhecimentos; e às características do processo de incorporação, aprendizado e difusão de conhecimentos.

A literatura aponta que o processo de busca e seleção da trajetória tecnológica dentro de um paradigma tecnológico é influenciado por fatores econômicos e não econômicos.

A capacidade de redução de custos da nova tecnologia e seu potencial para economizar mão-de-obra, assim como as características da demanda e as variações nos preços dos insumos usados na produção, orientam as escolhas por uma trajetória tecnológica, em detrimento de outras opções disponíveis em um paradigma.

Após a fase de seleção da trajetória, outros fatores influenciarão a viabilidade dessa trajetória tecnológica.

Neste ponto, a literatura destaca que a demanda de mercado, o Estado e a integração entre as atividades de pesquisa científica e empírica exercem papel importante para a consolidação da trajetória tecnológica escolhida.

As características da demanda e a atuação do Estado podem viabilizar e acentuar a difusão dos conhecimentos da trajetória tecnológica escolhida. A integração entre a pesquisa científica e empírica, por sua vez, pode ampliar o acervo de possibilidades tecnológicas daquela trajetória. 
Um fator importante é que a atuação do Estado e as características da demanda de mercado também podem transformar aquele processo de integração entre a ciência e o conhecimento empírico.

Isso porque as estruturas que viabilizam aquela integração podem ser orientadas para a resolução de problemas técnicos e para a comercialização das tecnologias, de acordo com o que é definido pelo Estado e pela demanda de mercado.

As empresas e setores industriais apresentam um padrão para a incorporação e o aprendizado de cada trajetória. E esse padrão dificultará a mudança da trajetória ao longo do tempo.

Há três fatores importantes do processo de incorporação e aprendizado das tecnologias que podem dificultar o abandono de uma trajetória tecnológica.

Em primeiro lugar, os conhecimentos criados e aprendidos ao longo do tempo são acumulados ao estoque de informações das empresas de diferentes setores industriais. Nesse cenário, como há uma interdependência entre o conhecimento anterior e o atual, as empresas podem enfrentar dificuldades para abandonar rotas pré-estabelecidas.

$\mathrm{Em}$ segundo lugar, os mecanismos utilizados para acessar as informações sobre tecnologias estão sujeitas a uma diversidade de condições no nível macroeconômico e no ambiente da firma.

Em terceiro lugar, as empresas e instituições apresentam incerteza em relação aos resultados de cada trajetória e, frequentemente, essa incerteza pode desestimular as mudanças de trajetória.

Os fatores que influenciam a escolha de uma trajetória e a sua viabilidade ao longo do tempo imprimem um regime tecnológico a cada setor industrial em cada país.

O regime tecnológico de um setor abrange as características do conhecimento interno às empresas, o grau e nível de cumulatividade desses conhecimentos, as condições de oportunidade para gerar inovações e as condições para proteger as informações de eventuais imitadores.

Desse modo, o regime ou ambiente tecnológico abrange as condições para a criação, incorporação e difusão dos conhecimentos entre os setores industriais. 
Os fatores que possibilitaram a escolha entre trajetórias tecnológicas e a formação dos setores industriais tendem a se perpetuar e influenciam as decisões e estratégias das empresas ao longo do tempo.

Uma alteração da trajetória escolhida é um processo que demanda tempo e apresenta custos porque aquelas condições iniciais repercutem em um tipo de ambiente tecnológico específico ao setor e ao país.

A noção sobre Sistema Setorial de Inovação pode ajudar a promover 0 desenvolvimento tecnológico e eventuais alterações na trajetória tecnológica de um setor.

Isso porque os atores e relações do Sistema Setorial podem ajudar a compreender os elementos do processo de desenvolvimento tecnológico. Nesse cenário, a integração das atividades de pesquisa científica e empírica, que possibilitaram a difusão inicial dos conhecimentos, também pode ser um mecanismo importante para viabilizar alterações na trajetória.

Paralelamente, os setores a jusante e a montante também contribuem para a difusão e o aprendizado daqueles conhecimentos, acentuando os efeitos das atividades de pesquisa científica e de produção.

A tese analisou a relação entre trajetória tecnológica, regime tecnológico e Sistema Setorial de Inovação considerando o desenvolvimento inicial e o dinamismo do setor de máquinas-ferramenta.

Nas economias industriais, a formação e consolidação do setor de máquinas-ferramenta foram viabilizadas pelo processo de especialização dos conhecimentos da área mecânica e pela convergência de tecnologias visando à resolução de problemas comuns a todos os ramos usuários das máquinas.

Ao longo do tempo, esses conhecimentos acumulados avançavam em diferentes direções e promoveram a formação de vários ramos industriais.

À medida que as empresas de diferentes ramos industriais incorporavam e utilizavam os conhecimentos para diferentes usos, verifica-se também a incorporação de informações provenientes de outras áreas ou a identificação de novas aplicações.

O ambiente institucional em que os setores de máquinas estavam inseridos apresentava particularidades que reforçavam a escolha entre as trajetórias tecnológica e influenciava a integração entre ciência e produção em cada segmento de máquina. 
Destaca-se que os conhecimentos empíricos da área de produção assumiam papel mais importante na definição dessas trajetórias, relativamente ao conhecimento científico.

Entretanto, à medida que o conhecimento empírico era difundido entre os setores industriais, a estrutura científica contribuía para a ampliação, incorporação e consolidação daqueles conhecimentos no sistema econômico.

Em países como a Inglaterra, os Estados Unidos e o Japão, por exemplo, o desenvolvimento industrial do setor de máquinas-ferramenta foi distinto porque o ambiente institucional e a demanda de mercado focavam em trajetórias tecnológicas diferentes.

Além disso, a integração entre a pesquisa científica e as atividades de produção em cada país reforçava as condições para o desenvolvimento tecnológico do setor de máquinas-ferramenta.

As empresas com produção de máquinas-ferramenta de cada um daqueles países adotavam estratégias visando à especialização ou diversificação dos conhecimentos. $E$ essas estratégias influenciavam o conjunto de informações que as empresas acumulavam ao longo do tempo.

Diante desse cenário, destaca-se que 0 conhecimento $e$ as competências acumulados por empresas e instituições apresentam papel decisivo para a identificação do potencial de novas tecnologias e a continuidade ou ruptura no padrão de desenvolvimento da tecnologia.

O desenvolvimento industrial do setor de máquinas-ferramenta do Brasil também foi influenciado pelo ambiente institucional e pela demanda de máquinas no mercado interno.

O Estado assumiu papel importante para a formação do setor de máquinas no mercado interno e deu as condições iniciais para 0 desenvolvimento das empresas.

Por outro lado, as flutuações econômicas exerciam forte influência sobre as expectativas da indústria da transformação nacional. E o setor produtivo, de maneira geral, alterava os investimentos na aquisição de máquinas usadas na ampliação da capacidade ou modernização fabril.

Esse fator pode ser apontado como um dos obstáculos à difusão inicial de conhecimentos no setor de máquinas-ferramenta do Brasil. Vale ressaltar que muitas empresas de máquinas-ferramenta do Brasil, salvo algumas 
exceções, não apresentaram o acúmulo de competências necessárias para identificação de novas trajetórias tecnológicas e para o aprendizado e a internalização dos conhecimentos.

Em grande medida, as empresas fabricantes de máquinas desenvolveram sua estrutura produtiva com base na especialização dos conhecimentos tecnológicos em engenharia mecânica.

A especialização dos conhecimentos, por sua vez, possibilitou a diversificação dos tipos de máquinas dentro de uma mesma linha. E esse fator é importante para o atendimento de demandas específicas dos usuários.

Além disso, a especialização dos conhecimentos tecnológicos se tornou fator importante para o setor amenizar os efeitos das variações da demanda no mercado interno.

As condições iniciais do desenvolvimento de tecnologias no interior das empresas de máquinas-ferramenta imprimiram um padrão de regime tecnológico do setor que abrange alta cumulatividade dos conhecimentos sob a base mecânica; baixa apropriabilidade e baixa condição de oportunidade para inovações.

A constituição e o desenvolvimento inicial do setor de máquinas no Brasil também estavam apoiados em elos fracos entre a pesquisa científica e empírica.

Com a mudança da política econômica e abertura do mercado nacional a partir década de 1980, algumas empresas nacionais apresentaram a revisão de suas estratégias produtivas e tecnológicas.

De maneira geral, as empresas começaram a investir tempo e esforços na atualização de conhecimentos e no estreitamento de relações com fornecedores e usuários.

Nos últimos anos deste século, destaca-se a preocupação do setor de máquinas em manter vínculos com instituições de ensino e pesquisa e Institutos com atividades de apoio.

Entretanto, os resultados da pesquisa empírica realizada com empresas fabricantes de máquinas e grupos de pesquisa localizados no Estado de São Paulo apontam que há poucos exemplos de interações estabelecidas entre esses agentes. 
De maneira geral, as empresas analisadas destacaram que a baixa integração entre a pesquisa científica e aplicada do setor de máquinasferramenta no Brasil pode ser justificada por fatores econômicos com o custo dos projetos e a falta de recursos financeiros por parte das empresas.

O estudo da tese não descarta essa justificativa econômica para a baixa frequência de interações entre empresas e grupos de pesquisa. Isso porque os fatores econômicos associados à inovação podem apresentar peso importante para a estrutura financeira das empresas, principalmente, aquelas de pequeno e médio porte.

Uma das contribuições é apontar que as estratégias produtivas adotadas no passado repercutiram em um padrão de regime tecnológico do setor de máquinas-ferramenta.

O regime tecnológico do setor de máquinas-ferramenta, por sua vez, apresenta papel decisivo para explicar a baixa integração entre pesquisa científica e produção; e a dinâmica competitiva e tecnológica do setor no mercado interno.

As empresas nacionais de máquinas-ferramenta de pequeno e médio porte apresentam elevada especialização dos conhecimentos na área mecânica e fabricam máquinas com tecnologias mais simples ou semiautomáticas. Por conta da especialização dos conhecimentos, as empresas deste grupo apresentam condições para realizar melhorias nos modelos de máquinas e não apresentam demanda tecnológica dos grupos de pesquisa.

As condições para promover melhorias incrementais em seus produtos conferem a essas empresas vantagens competitivas instáveis.

Além disso, a elevada especialização e a pequena integração entre essas empresas de máquinas e Institutos de pesquisa científica determinam poucas (ou nulas) condições para o desenvolvimento de tecnologias.

As empresas de máquinas-ferramenta de grande porte, por sua vez, apresentam especialização dos conhecimentos na área mecânica e têm investido na atualização de conhecimentos provenientes de outras áreas e em novas aplicações para as máquinas. Neste cenário, as empresas apresentam competências para desenvolver máquinas com tecnologias um pouco mais complexas, mas apresentam pouca demanda por serviços e pesquisa científica desenvolvidos nos grupos de pesquisa. 
Nos casos em que há interações, muitas vezes, esses contatos são direcionados mais para o teste de peças e uma parte dos conhecimentos das empresas não são compartilhados com os grupos de pesquisa.

A vantagem competitiva dessas empresas de máquinas-ferramenta também é frágil, mas não tão instável como no caso anterior.

Isso porque alguns produtos fabricados por essas empresas de grande porte podem representar novidade para o mercado interno e não são facilmente copiados por empresas nacionais de máquinas-ferramenta com atuação no mercado interno. Por outro lado, a inserção de empresas estrangeiras no ramo de atuação das empresas brasileiras pode interromper a competitividade da empresa nacional de máquinas-ferramenta.

$\mathrm{Na}$ década de 2000, uma pequena parte das empresas nacionais de máquinas-ferramenta de grande porte ampliou suas competências em processos e produtos e aumentou sua participação no comércio internacional de máquinas. Entretanto, o desempenho das empresas nacionais está condicionado às expectativas em relação à demanda nacional ou internacional por máquinas.

Como o desempenho industrial do setor de máquinas-ferramenta é instável, frequentemente, as estratégias inovativas de longo prazo são postergadas e substituídas por estratégias orientadas para a obtenção de resultados econômicos no curto prazo.

Nesse cenário, é possível apontar que o Sistema Setorial de Inovação de máquinas-ferramenta apresenta condições para alterar algumas características do ambiente tecnológico do setor de máquinas-ferramenta, particularmente entre as empresas de médio e grande porte.

Em grande medida, as pesquisas científicas realizadas no Brasil e as informações provenientes de fornecedores de componentes podem ampliar o leque de conhecimentos sobre o processo de produção das máquinasferramenta, contribuindo para uma diversificação da base de conhecimentos internos às empresas.

O domínio de conhecimentos menos especializados não implica necessariamente em abandono da trajetória tecnológica do setor, mas pode ampliar as competências para identificar novas trajetórias tecnológicas no futuro. 


\section{Referências Bibliográficas}

ALCORTA, L. (2000). New economic policies and the diffusion of machine tools in Latin America. World Development, V. 28, N. 9, p. 1657-1672.

ALEM, A. C. ; PESSOA, R. M (2005). O setor de bens de capital e o desenvolvimento econômico: quais os desafios? BNDES Setorial, Rio de Janeiro, n. 22, p. 71-88, set. 2005. Disponível em:

http://www.bndes.gov.br/SiteBNDES/export/sites/default/bndes pt/Galerias/Arquivos/conhecim ento/bnset/set2203.pdf

AVELLAR, A. P. (2008) Uma agenda de competitividade para a indústria paulista - setor de máquinas-ferramenta. Instituto de Pesquisas Tecnológicas do Estado de São Paulo (IPT)/FIPE. Secretaria de Desenvolvimento do Estado de São Paulo. Nota Técnica.

AVELLAR, A. P. M. ; STRACHMAN, E. (2008). Estratégias, Desenvolvimento Tecnológico e Inovação no Setor de Bens de Capital no Brasil. Ensaios FEE, v. 29, n. 01, p. 237-266, jun/2008.

BASTOS, R. L. A. (1999). As novas tecnologias de automação: desenvolvimento, atributos e implicações de sua adoção em termos de escalas. Revista Ensaios FEE. Porto Alegre, v. 20, n. 02, p. 189-219.

Disponível em: <http://revistas.fee.tche.br/index.php/ensaios/article/view/1955/2332>. Acesso em 05.jul.2010.

BRAVERMAN, H. (1987) Trabalho e capital monopolista: a degradação do trabalho no século XX. Rio de Janeiro, Guanabara.

BRESCHI, S.; MALERBA, F. (1997). Sectoral System of innovation: technological regimes, Schumpeterian dynamics and spatial boundaries. In: Edquist, C. (Ed.). Systems of Innovation Frances Pinter London

BUENSTORF, G.; GUENTHER, C. (2010). No place like home? Relocation, capabilities, and firm survival in the German machine tool industry after World War II. Industrial and Corporate Change. V. 20, N. 1, p. 1-28.

CIMM (2012). Centro de Informação Metal Mecânica. Disponível em: http://www.cimm.com.br/portal/noticia/material didatico/3350. Acesso em: 01. Out. 12. 
CNI (2012). Indicadores Industriais. Informativo da Confederação Nacional das Indústrias CNI), Ano 23, Número 06, Junho de 2012. Disponível em: http://www.cni.org.br/portal/data/pages/FF808081310B1CBB01314F1713B5119A.htm. Acesso em: 14. out.2012

CNPq (2012). Conselho Nacional de Desenvolvimento Científico e Tecnológico. Diretório Grupos de Pesquisa. Disponível em: http://dgp.cnpq.br/buscaoperacional/.

COHEN, W. M. e LEVINTHAL, D. A (1990). Absorptive Capacity: New Perspective on Learning and Innovation. Administrative Science Quarterly, v. 35, p. 128-152, 1990.

COLLINS, J.A (2006a). Seleção de materiais. In: Projeto Mecânico de Elementos de Máquinas: uma perspectiva de prevenção da falha. RJ: Livros Técnicos e Científicos Editora S.A. Capítulo 3.

(2006b). Etapas do projeto referente à integração dos requisitos de fabricação e manutenção. In: Projeto Mecânico de Elementos de Máquinas: uma perspectiva de prevenção da falha. RJ: Livros Técnicos e Científicos Editora S.A. Capítulo 7.

COMTRADE (2012). Data Availability by Commodity, United Nations Commodity Trade Statistics Database, Statistics Division. Disponível em: http://comtrade.un.org/db/mr/daCommodities.aspx. Acesso em: 04. out.2012.

COMTRADE (2011). Comtrade Explorer Snapshot, United Nations Commodity Trade Statistics Database, Statistics Division.

Disponível em: http://comtrade.un.org/db/ce/ceSnapshot.aspx?rg=1\&cc=7\&px=S3\&so=1\&qt=n . Acesso em: 12.fev.2011.

DOSI, G. (2006). Tendências da inovação e seus determinantes: os ingredientes do processo inovador. In: Mudança técnica e transformação industrial - a teoria e uma aplicação à indústria dos semicondutores. SZLAK, C. D (tradutor). Capítulo 2, p. 29-126. Clássicos da Inovação. Editora da Unicamp. Campinas - SP.

DOSI, G. (1988). Sources, Procedures and Microeconomic Effects of Innovation. Journal of Economic Literature. V. XXVI, N.3 (September 1988), p.1120-1171.

DOSI, G. (1982). Technological paradigms and technological trajectories. A suggested interpretation of the determinants and directions of technical change. Research Policy, V. 11, p. 147-162. 
FRANSMAN, M. (1982). Learning and the capital goods sector under free trade: the case of Hong Kong. World Development, V. 10, N. 11, p. 991-1104.

FRANSMAN, M. (1984). Conceptualising Technical Change in the Third World in the 1980s: An interpretative Survey. The Journal of Development Studies, p. 572-653, Oct/1984.

FRANSMAN, M. (1986). "New thinks on old themes". In: Technology and Economic Development. Wheatshead Books, Great Britain. Capítulo 2, pp. 7-21.

FURTADO (2003). Subdesenvolvimento e distribuição de renda. In: Raízes do subdesenvolvimento. Capítulo 3, p. $87-115$.

GARDNER (2012). World Machine Tool output \& consumption survey, 2012 e 2010. Gardner Publications. Disponível em: http://www.gardnerweb.com/articles/-2012-worldmachine-tool-output-and-consumption-survey.

GOMES, M. T. O; AYRES, M. L. A; FILHO, G. A. S. (1995). A indústria de máquinasferramenta. Publicações. Consulta Expressa. BNDES, Novembro/1995. Disponível em: http://www.bndes.gov.br/SiteBNDES/export/sites/default/bndes pt/Galerias/Arquivos/conhecim ento/bnset/set202.pdf.

HECKER, R. L; FLORES, G. M; XIE, Q; HARAN, R. (2008). Servocontrols of machine-tools: a review. Latin American Applied Research.

HELLER, C. (2006). Path-dependence, Lock-in e Inertia. In: PELAEZ, Victor e SZMRECSANY (2006). Economia da Inovação Tecnológica. Editora Hucitec, São Paulo. Capítulo 11, p. 260 284.

HITOMI, K. (1994). Automation - its concepts and a short history. Technovation. Vol. 14, no. 02, pp. 121-128.

IBGE (2012a). Pesquisa Industrial Anual Empresa. Banco de Dados agregados, Sistema de IBGE de Recuperação Automática (SIDRA).

Disponível em: http://www.sidra.ibge.gov.br/bda/tabela/protabl.asp?c=1848\&z=p\&o=16\&i=P.

IBGE (2012b). Banco de Dados agregados, Sistema de IBGE de Recuperação Automática (SIDRA).

Disponível em: http://www.sidra.ibge.gov.br/bda/tabela/protabl.asp?c=1848\&z=p\&o=16\&i=P. 
IBGE (2012c). Comissão Nacional de Classificação (CONCLA). Disponível em: http://www.cnae.ibge.gov.br/pesquisa.asp?action=anterior\&intPage=2\&Pesquisa=28402\&TipoOrdenacao=C\&TabelaBusca=CNAE_201@CNAE

Subclasses@0@cnaefiscal@0\&SourcePage=índex

ITSY (2010) International Trade Statistics Yearbook. United Nations Statistics Division, Department of Economic and Social Affairs. International Merchandise Trade Statistic (COMTRADE). Trade by commodity, Vol. II

Disponível em: http://comtrade.un.org/pb/. Acesso em: 12.fev.2011. Atualizado em: 04.out.2012.

KLEVORICK, A.; LEVIN, R.; NELSON, R.; WINTER, S. (1995). On the sources and significance of interindustry differences in technological opportunities. Research Policy, $24,2$.

LEE, K. R. (1996). The role of user firms in the innovation of machine tools: the Japanese case. Research Policy, V. 25, p. 491-507.

LUNDVALL, Bengt-Ake (1988). Innovation as an interactive process: from user-producer interaction to the national systems of innovation. In: Dosi, G. et al. Technical Change and Economy Theory. London: Pinter Publishers. p. 349-369, 1988.

(1992). User Producer Relationships, National Systems of Innovation and Internationalization. In: National Systems of Innovation: Towards a theory of innovation and interactive learning. Cap. 3, p. 45-67.

MALERBA, F. \& ORSENIGO, L (1993). Technological regimes and firm behavior. Industrial and Corporate Change. Vol. 02, p. 45-74.

MALERBA, F. (2000). Knowledge, Innovative Activities and Industrial Evolution. Industrial and Corporate Change. Vol. 9, p. 289-314.

MALERBA, F. (2002). Sectoral Systems of innovation and production. Research Policy, no. 31 , pp. 247-264.

MALERBA, F. (2004). Introduction. In: Sectoral Systems of Innovation: Concepts, Issues and Analyses of Six Major Sectors in Europe, pp. 1-12. 
MARX, K. (1983). Desenvolvimento da maquinaria. In: O Capital - crítica da economia política. Volume 1, Parte Quarta, Capítulo 13: A maquinaria e a indústria moderna, p. 423-440. São Paulo: Abril Cultural.

MAZZOLENI, R. (1997). Learning and path-dependence in the diffusion of innovations: comparative evidence on numerically controlled machine tools. Research Policy. Vol. 26, pp. 405-28.

MDIC/SECEX (2012). Exportações e Importações dos setores industriais por intensidade tecnológica. Departamento de Desenvolvimento e Planejamento do Comércio Exterior (DEPLA), Secretaria de Comércio Exterior (SECEX), Ministério do Desenvolvimento, Indústria e Comércio Exterior (MDIC). Disponível em: http://www.desenvolvimento.gov.br/sitio/interna/interna.php?area=5\&menu=1113

Acesso em: 06.fev.2011.

MORAES, C.; ABREU, C. M. (2006). A história das Máquinas: Abimaq 70 anos. Abimaq/Sindimaq. Magma Editora Cultural, São Paulo, 2006.

MOWERY; ROSENBERG, N. (1999). Paths of innovation: Technological Change in 20th Century America. New York, NY:Cambridge University Press, 214 pp. Introduction.

NELSON, R. R.; WINTER, S. (1982/2005). Uma Teoria Evolucionária da Mudança Técnica. HELLER, C. (trad.). Clássicos da Inovação. Campinas, SP: Editora da Unicamp.

PATEL P.; PAVITT, K., (1994). Uneven (and Divergent) Technological Accumulation among Advanced Countries: Evidence and a Framework of Explanation. Industrial and Corporate Change. Vol. 3, n.3, pp. 759-787.

PAVITT, K. (1984). Sectoral patterns of technical change: towards a taxonomy and a theory. Research Policy. Vol. 13, p.343-373.

PREBISCH, R. (1973). "Progresso técnico, industrialização e desequilíbrio". In: BIELSCHOWSKY, R. (org). Problemas Teóricos e Práticos do Crescimento Econômico. Cinquenta anos de pensamento da CEPAL. Editora Record, CEPAL, Cofecon, Rio de Janeiro e São Paulo, 2000, Vol. 1, pp. 179-215.

RAIS (2012). Disponível em: <http://www.rais.gov.br/RAIS_SITIO/tabelas.asp>. Acesso em: 31.out.2011. 
RESENDE, M. F. C. e ANDERSON, P. (1999). Mudanças estruturais na industria brasileira de bens de capital. Texto para discussão n. 658. Instituto de Pesquisas Econômicas Aplicadas (IPEA), Brasília, Julho de 1999. Disponível em: <http://www.ipea.gov.br/pub/td/td.html>

ROLFO, S. (1993). The Italian Machine Tool Industry. Working Papers n. 04, Institute for Economic Research on Firms and Growth (CERIS), National Research Council (CNR).

Disponível em: http://www.ceris.cnr.it/ceris/workingpaper/1993/wp04 93.pdf. Acesso em: 04.out.11

ROSENBERG, N. (1927/2006a). A historiografia do progresso técnico. In: MAIORINO, J. E. (trad.). Por dentro da caixa preta - tecnologia e economia. Capítulo 1, p. 17-65. Clássicos da Inovação. Campinas, SP: Editora da Unicamp.

ROSENBERG, N. (1927/2006b). Marx como estudioso da tecnologia. In: MAIORINO, J. E. (trad.). Por dentro da caixa preta - Tecnologia e econômica. Capítulo 2, p. 67-92. Clássicos da Inovação. Campinas, SP: Editora da Unicamp.

ROSENBERG, N. (1974). Science, Invention and economic Growth. Economic Development and cultural Change. Vol. 84, No. 33, (March/1974), pp. 90-108.

Disponível em: <http:/ideas.repec.org/a/ecj/econj//v84y1974i333p90-108.html>

ROSENBERG, N. (1970) Economic Development and the Transfer of Technology: some historical perspectives. Technology and Culture, Vol. 11, No. 4, pp. 550-575, Oct/1970.

ROSENBERG, N.(1969).The direction of technological change: inducement mechanisms and focusing devices. Economic Development and cultural Change. Vol. 18, No. 01, Part. 1 (October/1969), pp. 1-24. Disponível em:

<http://econpapers.repec.org/article/ucpecdecc/v_3a18_3ay_3a1969_3ai_3a1_3ap_3a1-24.htm>

ROSENBERG, N. (1963). Technological change in the Machine Tool Industry, 1840-1910. The Journal of Economic History. Vol. 23, No. 04, (Dec/1963), pp. 414-443.

ROVERE, Renata Lèbre La (2006). Paradigmas e Trajetórias Tecnológicas. In: Economia da Inovação Tecnológica. Série Economia \& Planejamento. Victor Pelaez e Tamas Szmrecsányi, (org.). Editora Hucitec: São Paulo, p. 285-301.

SABBATINI, R. (2009). Perspectiva do Investimento em Mecânica. Equipe Beatriz Bertasso et al. Rio de Janeiro: UFRJ, Instituto de Economia, 2008/2009. 252 p. Relatório integrante da pesquisa "Perspectivas do Investimento no Brasil", em parceria com o Instituto de Economia da UNICAMP, financiada pelo BNDES. Disponível em: http://www.projetopib.org/?p=documentos 
Acesso em: 06. Abr. 2012

SABATO, J. A. (1979). "El comercio de tecnologia". In: SABATO, J. A. Ensayos de Campera. Juarez Editor, Buenos Aires. Capitulo IV, pp. 59-95.

TAUILE, R. (1993). Automação industrial e diferentes alternativas de organização do trabalho e da produção. Revista Indicadores Econômicos FEE. Vol. 21, No. 01

Disponível em: http://revistas.fee.tche.br/index.php/indicadores/article/view/410/642

UNCTAD (2010). Unctad Handbook of Statistics. Disponível em:

http://archive.unctad.org/Templates/webflyer.asp?docid=16171\&intltemID=5772\&lang=1

Acesso em: 02.mar.2011.

UNIDO (2012). INDSTAT4 (Industrial Statistics Database), Statistics Division, Disponível em:

Disponível em: <http://data.un.org/Data.aspx?d=UNIDO\&f=tableCode\%3a01>. Acesso em: 04.

Out. 12.

VERMULM, R. (1996). Estratégias empresariais nos anos 80: o setor de máquinasferramenta. Caderno de Gestão Tecnológica. Número 30. Núcleo de Política e Gestão Tecnológica (NPGT), Faculdade de Administração, Economia e Contabilidade da USP. Disponível em: http://www.fundacaofia.com.br/pgtusp/publicacoes/arquivos_cyted/Cad30.PDF. Acesso em: 21. dez. 2011.

VERMULM, R. (2003). A indústria de bens de capital seriados. Comissão Econômica para a América Latina e o Caribe (CEPAL). Publicações.

Disponível em: http:/www.eclac.org/publicaciones/xml/4/21524/LCBRS147RobertoVermulm.pdf. Acesso em: 21. dez. 2011.

VERLMULM, R. (1993). O Setor de bens de capital. Disponível em: http://www.schwartzman.org.br/simon/scipol/pdf/vermulm.pdf. Acesso em: 21. dez. 2011.

WENGEL, J. \& SHAPIRA, P.(2001). Machine Tools: The remanking of a Traditional Sectoral Innovation System? Final Paper. In: Sectoral Systems in Europe - Innovation, Competitiveness and Growth (ESSY). November/2001. Disponível em: http://www2.cespri.unibocconi.it/essy/wp/wengshap.pdf. 


\section{Anexos}

Anexo A - Classificações sobre a indústria de bens de capital .......................227

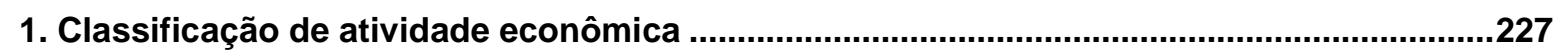

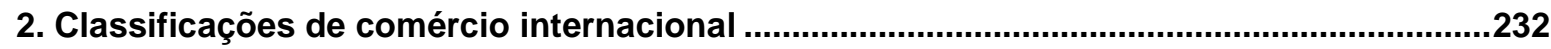

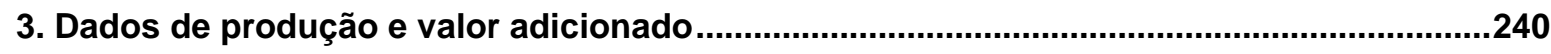

Anexo B - Lista geral de empresas e grupos de pesquisa identificados

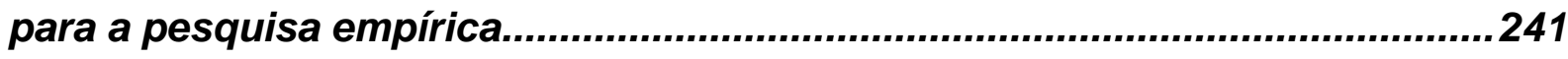

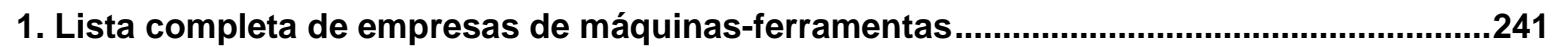

Anexo C - Questionário utilizado na pesquisa empírica ...................................243

1. Questionários aplicado em empresas de máquinas-ferramenta ..........................................243

2. Questionário aplicado nos grupos de pesquisa com atuação no ramo de máquinasferramenta.

Anexo C - Informações sobre as empresas e os grupos de pesquisa

1. Informações sobre as empresas de máquinas-ferramenta e as linhas de produtos fabricados

2. Notas técnicas sobre as empresas de máquinas-ferramenta visitadas ............................266

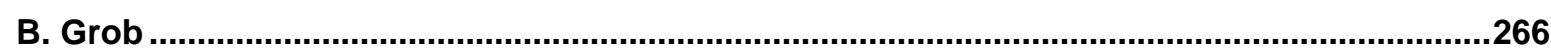

D. R. Promaq

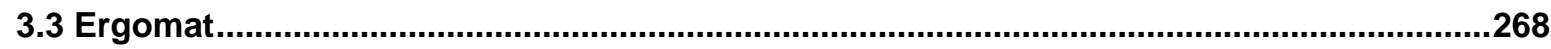

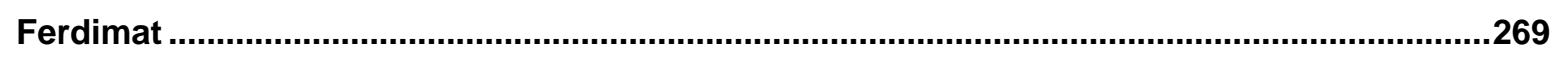

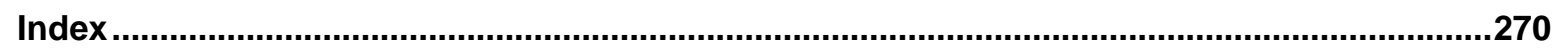

Indústrias Romi

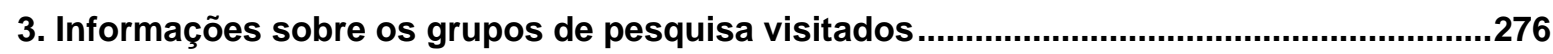




\section{ANEXO A - CLASSIFICAÇÕES SOBRE A INDÚSTRIA DE BENS DE CAPITAL}

\section{Classificação de atividade econômica}

Quadro 1 - Estrutura de atividades da indústria de bens de capital a três e quatro dígitos - ISIC 4⿳亠丷a $\cdot$ Rev.4 (2008)

\begin{tabular}{|c|c|c|}
\hline Group & Class & Description \\
\hline \multicolumn{3}{|r|}{ 27: Manufacture of electrical equipment } \\
\hline 271 & & $\begin{array}{l}\text { Manufacture of electric motors, generators, transformers and electricity } \\
\text { distribution and control apparatus }\end{array}$ \\
\hline 272 & & Manufacture of batteries and accumulators \\
\hline 273 & & Manufacture of wiring and wiring devices \\
\hline 274 & & Manufacture of electric lighting equipment \\
\hline 275 & & Manufacture of domestic appliances \\
\hline 279 & & Manufacture of other electrical equipment \\
\hline \multicolumn{3}{|r|}{ 28: Manufacture of machinery and equipment n.e.c. } \\
\hline \multirow[t]{10}{*}{281} & & Manufacture of general-purpose machinery \\
\hline & 2811 & $\begin{array}{l}\text { Manufacture of engines and turbines, except aircraft, vehicle and cycle } \\
\text { engines }\end{array}$ \\
\hline & 2812 & Manufacture of fluid power equipment \\
\hline & 2813 & Manufacture of other pumps, compressors, taps and valves \\
\hline & 2814 & Manufacture of bearings, gears, gearing and driving elements \\
\hline & 2815 & Manufacture of ovens, furnaces and furnace burners \\
\hline & 2816 & Manufacture of lifting and handling equipment \\
\hline & 2817 & $\begin{array}{l}\text { Manufacture of office machinery and equipment (except computers and } \\
\text { peripheral equipment) }\end{array}$ \\
\hline & 2818 & Manufacture of power-driven hand tools \\
\hline & 2819 & Manufacture of other general-purpose machinery \\
\hline \multirow[t]{8}{*}{282} & & Manufacture of special-purpose machinery \\
\hline & 2821 & Manufacture of agricultural and forestry machinery \\
\hline & 2822 & Manufacture of metal-forming machinery and machine tools \\
\hline & 2823 & Manufacture of machinery for metallurgy \\
\hline & 2824 & Manufacture of machinery for mining, quarrying and construction \\
\hline & 2825 & Manufacture of machinery for food, beverage and tobacco processing \\
\hline & 2826 & Manufacture of machinery for textile, apparel and leather production \\
\hline & 2829 & Manufacture of other special-purpose machinery \\
\hline \multicolumn{3}{|r|}{ 29: Manufacture of motor vehicles, trailers and semi-trailers } \\
\hline 291 & & Manufacture of motor vehicles \\
\hline
\end{tabular}




\begin{tabular}{|c|c|l|}
\hline 292 & & $\begin{array}{l}\text { Manufacture of bodies (coachwork) for motor vehicles; manufacture of } \\
\text { trailers and semi-trailers } \\
\text { Manufacture of parts and accessories for motor vehicles }\end{array}$ \\
\hline 293 & \multicolumn{2}{|l|}{ 30: Manufacture of other transport equipment } \\
\hline 301 & Building of ships and boats \\
\hline 302 & Manufacture of railway locomotives and rolling stock \\
\hline 303 & Manufacture of air and spacecraft and related machinery \\
\hline 304 & Manufacture of military fighting vehicles \\
\hline 309 & Manufacture of transport equipment n.e.c. \\
\hline
\end{tabular}

Fonte: United Nations Statistics Division (UNSD), UNCTAD.

Classificação com base nos dos dados de International Standard of Industrial Classification (ISIC) $4^{\text {a }}$ Rev (2008), p. 50. Disponível em: <http://unstats.un.org/unsd/publication/seriesM/seriesm_4rev4e.pdf.> Acesso em: 01/fev/2011.

Quadro 2 - Estrutura de atividades da indústria de bens de capital a três e quatro dígitos - ISIC $4^{\mathrm{a}}$.Rev.3

\begin{tabular}{|c|c|c|}
\hline Group & Class & Description \\
\hline \multicolumn{3}{|r|}{ Division 29: Manufacture of machinery and equipment n.e.c. } \\
\hline \multirow[t]{7}{*}{291} & & Manufacture of general purpose machinery \\
\hline & 2911 & Manufacture of engines and turbines, except aircraft, vehicle and cycle engines \\
\hline & 2912 & Manufacture of pumps, compressors, taps and valves \\
\hline & 2913 & Manufacture of bearings, gears, gearing and driving elements \\
\hline & 2914 & Manufacture of ovens, furnaces and furnace burners \\
\hline & 2915 & Manufacture of lifting and handling equipment \\
\hline & 2919 & Manufacture of other general purpose machinery \\
\hline \multirow[t]{9}{*}{292} & & Manufacture of special purpose machinery \\
\hline & 2921 & Manufacture of agricultural and forestry machinery \\
\hline & 2922 & Manufacture of machine-tools \\
\hline & 2923 & Manufacture of machinery for metallurgy \\
\hline & 2924 & Manufacture of machinery for mining, quarrying and construction \\
\hline & 2925 & Manufacture of machinery for food, beverage and tobacco processing \\
\hline & 2926 & Manufacture of machinery for textile, apparel and leather production \\
\hline & 2927 & Manufacture of weapons and ammunition \\
\hline & 2929 & Manufacture of other special purpose machinery \\
\hline \multirow[t]{2}{*}{293} & & Manufacture of domestic appliances n.e.c. \\
\hline & 2930 & Manufacture of domestic appliances n.e.c. \\
\hline
\end{tabular}


Quadro 3 - Descrição dos produtos incluídos na classe de máquinas-ferramenta (ISIC 2822)

\begin{tabular}{|c|c|}
\hline Products & Description \\
\hline $\begin{array}{l}\text { Machine-tools for working any } \\
\text { material by removal of material }\end{array}$ & $\begin{array}{l}\text { Machine-tools for working any material by removal of } \\
\text { material, by laser or other light or photon beam, ultrasonic, } \\
\text { electro-discharge, electro-chemical, electron beam, ionic- } \\
\text { beam or plasma arc processes. }\end{array}$ \\
\hline Lathes for removing metal & $\begin{array}{l}\text { Lathes including turning centres for removing metal, } \\
\text { horizontal, numerically controlled or otherwise. }\end{array}$ \\
\hline $\begin{array}{l}\text { Machine-tools for drilling, boring or } \\
\text { milling metal }\end{array}$ & $\begin{array}{l}\text { Machine-tools (including way-type unit head machines) for } \\
\text { drilling, boring, milling, threading or tapping by removing } \\
\text { metal, other than lathes and turning centres. }\end{array}$ \\
\hline Grinding and sharpening machines & $\begin{array}{l}\text { Grinding and sharpening machines, numerically controlled } \\
\text { or otherwise. }\end{array}$ \\
\hline $\begin{array}{l}\text { Metal finishing machines except } \\
\text { grinding and sharpening machines }\end{array}$ & $\begin{array}{l}\text { All other metal finishing machines except grinding and } \\
\text { sharpening machines, such as: Honing or lapping } \\
\text { machines, machine-tools for planing, shaping, slotting, } \\
\text { broaching, gear cutting, gear grinding or gear finishing, } \\
\text { sawing, cutting-off and other machine-tools working by } \\
\text { removing metal or cermets and other metal finishing } \\
\text { machines except grinding and sharpening machines. }\end{array}$ \\
\hline Machine tools for working metal & $\begin{array}{l}\text { Machine-tools for working metal by forging, hammering or } \\
\text { die-stamping; machine-tools for working metal by bending, } \\
\text { folding, straightening, flattening, shearing, punching or } \\
\text { notching; other presses for working metal or metal } \\
\text { carbides }\end{array}$ \\
\hline
\end{tabular}

Fonte: Statistics Division, United Nations Industrial Development Organization (UNIDO).69

Classificação com base nos dados da Lista de produtos por classe da ISIC 4.

Disponível em: <http://unstats.un.org/unsd/industry/commoditylist2.asp?s=1\&Lg=1> Acesso em: 04/out/12.

\footnotetext{
69 "The INDSTAT4 database contains time series data from 1990 onwards. Data are available for country, year and ISIC at the 3- and 4-digit levels of ISIC (Revision 3), which comprises 151 manufacturing sectors and sub-sectors. All value data are originally stored in national currency at current prices. The system allows for data conversion from national currency into current US dollars using the average period exchange rates as given in the International Monetary Fund International Financial Statistics (IFS). In support of the statistical data, relevant metadata information is collected from national data suppliers and OECD, which is available to users in a highly flexible form" (Research and Statistic, UNIDO 2012).
} 
Quadro 4 - Estrutura de atividades da indústria de bens de capital a quatro dígitos CNAE

\begin{tabular}{|c|c|c|}
\hline Classe & Subclasse & Descrição \\
\hline \multicolumn{3}{|c|}{ Grupo 28: Fabricação de máquinas e equipamentos } \\
\hline \multirow[t]{6}{*}{281} & & $\begin{array}{l}\text { Fabricação de motores, bombas, compressores e } \\
\text { equipamentos de transmissão }\end{array}$ \\
\hline & $2811-9$ & $\begin{array}{l}\text { Fabricação de motores e turbinas, exceto para aviões e } \\
\text { veículos rodoviários }\end{array}$ \\
\hline & $2812-7$ & $\begin{array}{l}\text { Fabricação de equipamentos } \\
\text { pneumáticos,exceto válvulas }\end{array}$ \\
\hline & $2813-5$ & Fabricação de válvulas, registros e dispositivos semelhantes \\
\hline & $2814-3$ & Fabricação de compressores \\
\hline & $2815-1$ & $\begin{array}{l}\text { Fabricação de equipamentos de transmissão para fins } \\
\text { industriais }\end{array}$ \\
\hline \multirow[t]{7}{*}{282} & & Fabricação de máquinas e equipamentos de uso geral \\
\hline & $2821-6$ & $\begin{array}{l}\text { Fabricação de aparelhos e equipamentos para instalações } \\
\text { térmicas }\end{array}$ \\
\hline & $2822-4$ & $\begin{array}{l}\text { Fabricação de máquinas, equipamentos e aparelhos para } \\
\text { transporte e elevação de cargas e pessoas }\end{array}$ \\
\hline & $2823-2$ & $\begin{array}{l}\text { Fabricação de máquinas e aparelhos de refrigeração e } \\
\text { ventilação para uso industrial e comercial }\end{array}$ \\
\hline & $2824-1$ & Fabricação de aparelhos e equipamentos de ar condicionado \\
\hline & $2825-9$ & $\begin{array}{l}\text { Fabricação de máquinas e equipamentos para saneamento } \\
\text { básico e ambiental }\end{array}$ \\
\hline & $2819-1$ & $\begin{array}{l}\text { Fabricação de máquinas e equipamentos de uso geral não } \\
\text { especificado anteriormente }\end{array}$ \\
\hline \multirow[t]{4}{*}{283} & & $\begin{array}{l}\text { Fabricação de tratores e de máquinas e equipamentos } \\
\text { para a agricultura e pecuária }\end{array}$ \\
\hline & $2831-3$ & Fabricação de tratores agrícolas \\
\hline & $2832-1$ & Fabricação de equipamentos para irrigação agrícola \\
\hline & $2833-0$ & $\begin{array}{l}\text { Fabricação de máquinas e equipamentos para a agricultura e } \\
\text { pecuária, exceto para irrigação }\end{array}$ \\
\hline \multirow[t]{2}{*}{284} & & Fabricação de máquinas-ferramenta \\
\hline & $2840-2$ & Fabricação de máquinas-ferramenta \\
\hline \multirow[t]{2}{*}{285} & & $\begin{array}{l}\text { Fabricação de máquinas e equipamentos de uso na } \\
\text { extração mineral e na construção }\end{array}$ \\
\hline & $2851-8$ & $\begin{array}{l}\text { Fabricação de máquinas e equipamentos para prospecção e } \\
\text { extração de petróleo }\end{array}$ \\
\hline
\end{tabular}




\begin{tabular}{|l|c|l|}
\hline & $2852-6$ & $\begin{array}{l}\text { Fabricação de outras máquinas e equipamentos para uso na } \\
\text { extração mineral, exceto na extração de petróleo }\end{array}$ \\
\hline $2853-4$ & Fabricação de tratores, exceto agrícolas \\
\hline 2864 & $\begin{array}{l}\text { Fabricação de máquinas e equipamentos para terraplenagem, } \\
\text { pavimentação e construção, exceto tratores }\end{array}$ \\
\hline $2861-5$ & $\begin{array}{l}\text { Fabricação de máquinas e equipamentos de uso } \\
\text { industrial especifico }\end{array}$ \\
\hline & $\begin{array}{l}\text { Fabricação de máquinas para a indústria metalúrgica, exceto } \\
\text { máquinas-ferramenta }\end{array}$ \\
\hline $2862-3$ & $\begin{array}{l}\text { Fabricação de máquinas e equipamentos para as indústrias } \\
\text { de alimentos, bebidas e fumo }\end{array}$ \\
\hline $2864-1$ & $\begin{array}{l}\text { Fabricação de máquinas e equipamentos para a indústria } \\
\text { têxtil }\end{array}$ \\
\hline $2865-8$ & $\begin{array}{l}\text { Fabricação de máquinas e equipamentos para a indústria do } \\
\text { vestuário, couro e de calçados }\end{array}$ \\
\hline $2866-6$ & $\begin{array}{l}\text { Fabricação de máquinas e equipamentos para a indústria de } \\
\text { celulose, papel e papelão e artefatos }\end{array}$ \\
\hline Fabricação de máquinas e equipamentos para a indústria do \\
\hline
\end{tabular}

Fonte: Retirado de CONCLA (2011). Descrição CNAE 2.1 - Subclasses.

Disponível em: <http://www.cnae.ibge.gov.br/divisao.asp?coddivisao=28\&CodSecao=C\&TabelaBusca=CNAE 201@CNAE 2.1-Subclasses@0@cnaefiscal@0> 


\section{Classificações de comércio internacional}

Quadro 4 - Padrão de Classificação de comércio internacional para a indústria de máquinaria e equipamentos de transporte (dois dígitos), segundo a Standard International Trade Classification (SITC), Rev.3

\begin{tabular}{|l|l|}
\hline \multicolumn{1}{|c|}{ SITC } & \multicolumn{1}{c|}{ Sescription } \\
\hline \multicolumn{2}{|c|}{ SIT: Machinery and transport equipment } \\
\hline 71 & Power-generating machinery and equipment \\
\hline 72 & Machinery specialized for particular industries \\
\hline 73 & Metal working machinery \\
\hline 74 & General industrial machinery and equipment, n.e.s., and machine parts, n.e.s. \\
\hline 75 & Office machines and automatic data-processing machines \\
\hline 76 & Telecommunications and sound-recording and reproducing apparatus and equipment \\
\hline 77 & Electrical machinery, apparatus and appliances, n.e.s., and electrical parts thereof \\
(including non-electrical counterparts, n.e.s., of electrical household-type equipment)
\end{tabular}

Fonte: Unctad Handbook Statistic (2010), com base no Standard International Trade Classification (SITC), Rev.3. 
Quadro 5 - Padrão de Classificação de comércio internacional para os segmentos da indústria de máquinaria e equipamentos de transporte (três dígitos), segundo o

Standard International Trade Classification (SITC), Rev.3

\begin{tabular}{|c|c|}
\hline $\begin{array}{c}\text { SITC } \\
\text { (3 dígitos) }\end{array}$ & Descrição \\
\hline \multicolumn{2}{|c|}{ 72: Machinery specialized for particular industries } \\
\hline 721 & Agricultural machinery (excluding tractors), and parts thereof \\
\hline 722 & Tractors (other than those of headings 744.14 and 744.15 ) \\
\hline 723 & civil engineering and contractors' plant and equipment; parts thereof \\
\hline 724 & Textile and leather machinery, and parts thereof, n.e.s. \\
\hline 725 & $\begin{array}{l}\text { Paper mill and pulp mill machinery, paper-cutting machines and other machinery for } \\
\text { the manufacture of paper articles; parts thereof }\end{array}$ \\
\hline 726 & Printing and bookbinding machinery, and parts thereof \\
\hline 727 & Food-processing machines (excluding domestic); parts thereof \\
\hline 728 & $\begin{array}{l}\text { Other machinery and equipment specialized for particular industries; parts thereof, } \\
\text { n.e.s. }\end{array}$ \\
\hline \multicolumn{2}{|c|}{73 : Metalworking machinery } \\
\hline 731 & Machine tools working by removing metal or other material \\
\hline 733 & $\begin{array}{l}\text { Machine tools for working metal, sintered metal carbides or cermets, without } \\
\text { removing material }\end{array}$ \\
\hline 735 & $\begin{array}{l}\text { Parts, n.e.s., and accessories suitable for use solely or principally with the machines } \\
\text { falling within groups } 731 \text { and } 733 \text { (including work or tool holders, self-opening die- } \\
\text { heads, dividing heads and other special attachments for machine tools); tool holders } \\
\text { for any type of tool for working in the hand }\end{array}$ \\
\hline 737 & Metalwork machinery (other than machine tools), and parts thereof, n.e.s. \\
\hline \multicolumn{2}{|c|}{ 74: General industrial machinery and equipment, n.e.s., and machine parts, n.e.s. } \\
\hline 741 & Heating and cooling equipment, and parts thereof, n.e.s. \\
\hline 742 & $\begin{array}{l}\text { Pumps for liquids, whether or not fitted with a measuring device; liquid elevators; } \\
\text { parts for such pumps and liquid elevators }\end{array}$ \\
\hline 743 & $\begin{array}{l}\text { Pumps (other than pumps for liquids), air or other gas compressors and fans; } \\
\text { ventilating or recycling hoods incorporating a fan, whether or not fitted with filters; } \\
\text { centrifuges; filtering or purifying apparatus; parts thereof }\end{array}$ \\
\hline 744 & Mechanical handling equipment, and parts thereof, n.e.s \\
\hline 745 & Non-electrical machinery, tools and mechanical apparatus, and parts thereof, n.e.s. \\
\hline 746 & Ball- or roller bearings \\
\hline 747 & $\begin{array}{l}\text { Taps, cocks, valves and similar appliances for pipes, boiler shells, tanks, vats or the } \\
\text { like, including pressure-reducing valves and thermostatically controlled valves }\end{array}$ \\
\hline 748 & Transmission shafts (including camshafts and cral \\
\hline
\end{tabular}




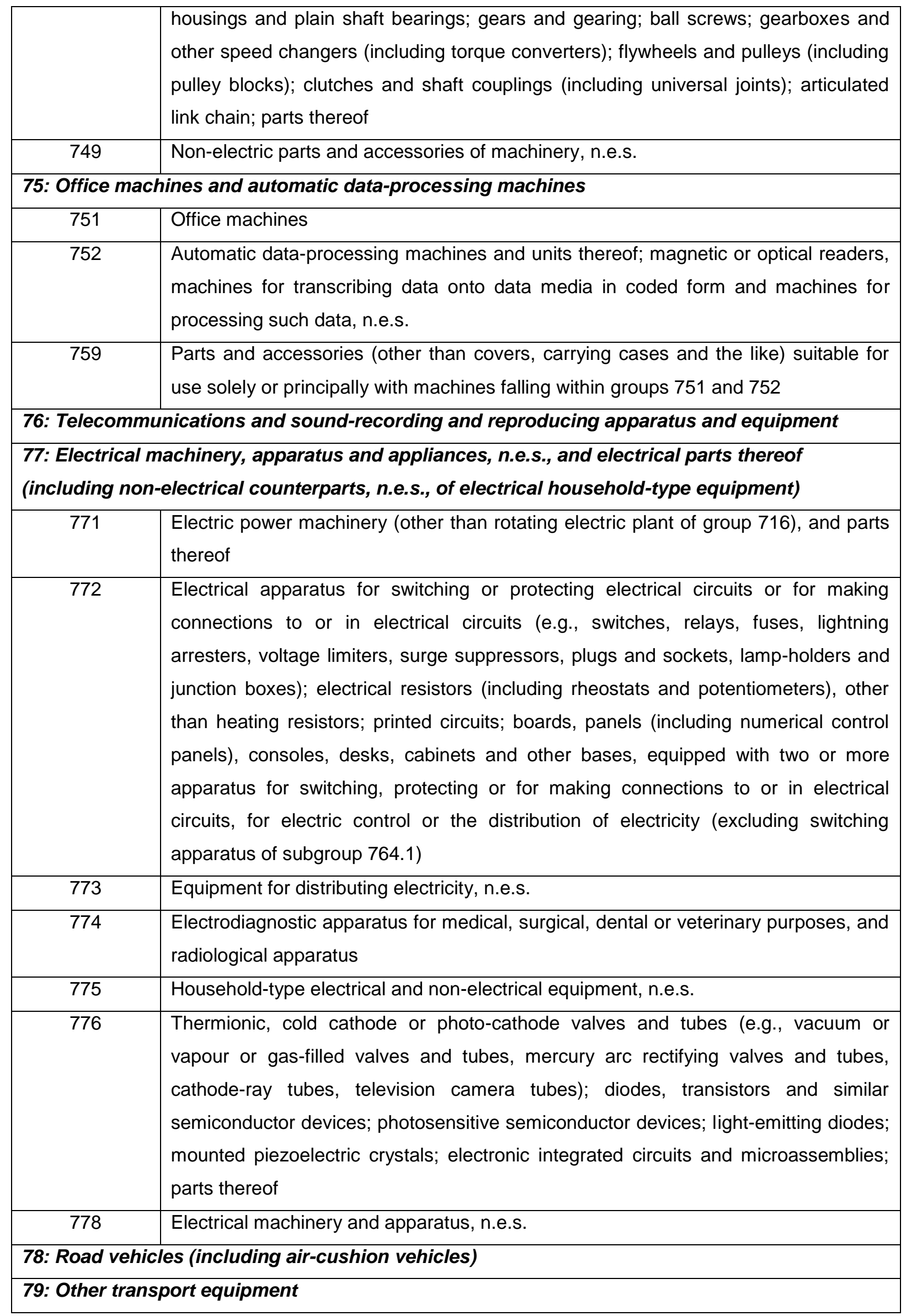

Fonte: Unctad Handbook Statistic (2010), com base no Standard International Trade Classification (SITC), Rev.3. 
Quadro 6 - Padrão de Classificação de comércio internacional para o capítulo 84 (quatro dígitos), segundo a Nomenclatura Comum do Mercosul (NCM)

\begin{tabular}{|c|c|}
\hline & ção \\
\hline \multicolumn{2}{|r|}{$\begin{array}{l}\text { Capítulo 84: Reatores nucleares, caldeiras, máquinas, aparelhos e instrumentos mecânicos, e suas } \\
\text { partes }\end{array}$} \\
\hline 84.50 & Máquinas de lavar roupa, mesmo com c \\
\hline 84.51 & $\begin{array}{l}\text { Máquinas e aparelhos (exceto as máquinas da posição 84.50) para lavar, limpar, } \\
\text { espremer, secar, passar, prensar (incluídas as prensas fixadoras), branquear, tingir, para } \\
\text { apresto e acabamento, para revestir ou impregnar fios, tecidos ou obras de matérias } \\
\text { têxteis e máquinas para revestir tecidos-base ou outros suportes utilizados na fabricação } \\
\text { de revestimentos para pavimentos (pisos), tais como linóleo; máquinas para enrolar, } \\
\text { desenrolar, dobrar, cortar ou dentear tecidos. }\end{array}$ \\
\hline 84.52 & $\begin{array}{l}\text { Máquinas de costura, exceto as de costurar cadernos da posição 84.40; móveis, bases e } \\
\text { tampas, próprios para máquinas de costura; agulhas para máquinas de costura. }\end{array}$ \\
\hline 84.53 & $\begin{array}{l}\text { Máquinas e aparelhos para preparar, curtir ou trabalhar couros ou peles, ou para fabricar } \\
\text { ou consertar calçados e outras obras de couro ou de pele, exceto máquinas de costura. }\end{array}$ \\
\hline 84.54 & $\begin{array}{l}\text { Conversores, cadinhos ou colheres de fundição, lingoteiras e máquinas de vazar (moldar) } \\
\text { para metalurgia, aciaria ou fundição. }\end{array}$ \\
\hline 55 & indros. \\
\hline 84.56 & $\begin{array}{l}\text { Máquinas-ferramenta que trabalhem por eliminação de qualquer matéria, operando } \\
\text { por "laser" ou por outro feixe de luz ou de fótons, por ultra-som, por eletroerosão, } \\
\text { por processos eletroquímicos, por feixes de elétrons, por feixes iônicos ou por jato } \\
\text { de plasma. }\end{array}$ \\
\hline 84.57 & $\begin{array}{l}\text { Centros de usinagem, máquinas de sistema monostático ("single station") } \\
\text { máquinas de estações múltiplas, para trabalhar metais. }\end{array}$ \\
\hline 84.58 & Tornos (incluídos os centros de torneamento) para metais. \\
\hline 84.59 & $\begin{array}{l}\text { Máquinas-ferramenta (incluídas as unidades com cabeça deslizante) para furar, } \\
\text { mandrilar, fresar ou roscar interior e exteriormente metais, por eliminação de } \\
\text { matéria, exceto os tornos (incluídos os centros de torneamento) da posição } 84.58 \text {. }\end{array}$ \\
\hline 84.60 & $\begin{array}{l}\text { Máquinas-ferramenta para rebarbar, afiar, amolar, retificar, brunir, polir ou realizar outras } \\
\text { operações de acabamento em metais ou ceramais ("cermets") por meio de mós, de } \\
\text { abrasivos ou de produtos polidores, exceto as máquinas de cortar ou acabar engrenagens } \\
\text { da posição } 84.61 \text {. }\end{array}$ \\
\hline 8461 & $\begin{array}{l}\text { Máquinas-ferramenta para aplainar, plainas-limadoras, máquinas-ferramenta para } \\
\text { escatelar, brochar, cortar ou acabar engrenagens, serrar, seccionar e outras máquinas- } \\
\text { ferramenta que trabalhem por eliminação de metal ou de ceramais ("cermets"), não } \\
\text { especificadas nem compreendidas em outras posições. }\end{array}$ \\
\hline 8462 & Má \\
\hline
\end{tabular}




\begin{tabular}{|c|c|}
\hline & $\begin{array}{l}\text { pilões e martinetes, para trabalhar metais; máquinas-ferramenta (incluídas as prensas) } \\
\text { para enrolar, arquear, dobrar, endireitar, aplanar, cisalhar, puncionar ou chanfrar metais; } \\
\text { prensas para trabalhar metais ou carbonetos metálicos, não especificadas acima. }\end{array}$ \\
\hline 8463 & $\begin{array}{l}\text { Outras máquinas-ferramenta para trabalhar metais ou ceramais (“cermets"), que } \\
\text { trabalhem sem eliminação de matéria. }\end{array}$ \\
\hline 8464 & $\begin{array}{l}\text { Máquinas-ferramenta para trabalhar pedra, produtos cerâmicos, concreto, fibrocimento ou } \\
\text { matérias minerais semelhantes, ou para o trabalho a frio do vidro. }\end{array}$ \\
\hline 8465 & $\begin{array}{l}\text { Máquinas-ferramenta (incluídas as máquinas para pregar, grampear, colar ou reunir por } \\
\text { qualquer outro modo) para trabalhar madeira, cortiça, osso, borracha endurecida, } \\
\text { plásticos duros ou matérias duras semelhantes. }\end{array}$ \\
\hline 8466 & $\begin{array}{l}\text { Partes e acessórios reconhecíveis como exclusiva ou principalmente destinados às } \\
\text { máquinas das posições } 84.56 \text { a } 84.65 \text {, incluídos as porta-peça e porta-ferramentas, as } \\
\text { fieiras de abertura automática, os dispositivos divisores e outros dispositivos especiais, } \\
\text { para máquinas-ferramenta; porta-ferramentas para ferramentas manuais de todos os } \\
\text { tipos. }\end{array}$ \\
\hline 8467 & $\begin{array}{l}\text { Ferramentas pneumáticas, hidráulicas ou com motor (elétrico ou não elétrico) } \\
\text { incorporado, de uso manual. }\end{array}$ \\
\hline 8468 & $\begin{array}{l}\text { Máquinas e aparelhos para soldar, mesmo de corte, exceto os da posição 85.15; } \\
\text { máquinas e aparelhos a gás, para têmpera superficial. }\end{array}$ \\
\hline 8469 & $\begin{array}{l}\text { Máquinas de escrever, exceto as impressoras da posição 84.43; máquinas de tratamento } \\
\text { de textos. }\end{array}$ \\
\hline
\end{tabular}

Fonte: Retirado de Ministério de Desenvolvimento, Indústria e Comércio. Comércio Exterior - Estatísticas de comércio exterior. Disponível em: http://www.mdic.gov.br/sitio/interna/interna.php?area=5\&menu=1095

Quadro 7 - Padrão de Classificação de comércio internacional para o capítulo 85 (quatro dígitos), segundo a Nomenclatura Comum do Mercosul (NCM)

\begin{tabular}{|c|l|}
\hline Subgrupo & \multicolumn{1}{c|}{ Descrição } \\
\hline $\begin{array}{c}\text { Capítulo 85: Máquinas, aparelhos e materiais elétricos, e suas partes; aparelhos de gravação ou de reprodução } \\
\text { de som,aparelhos de gravação ou de reprodução de imagens e de som em televisão, e suas partes e acessórios }\end{array}$ \\
\hline 85.01 & Motores e geradores, elétricos, exceto os grupos eletrogêneos. \\
\hline 85.02 & Grupos eletrogêneos e conversores rotativos elétricos. \\
\hline 8503 & $\begin{array}{l}\text { Partes reconhecíveis como exclusiva ou principalmente destinadas às máquinas das posiçães } \\
85.01 \text { ou 85.02. }\end{array}$ \\
\hline 85.04 & $\begin{array}{l}\text { Transformadores elétricos, conversores elétricos estáticos (retificadores, por exemplo), bobinas de } \\
\text { reatância e de auto-indução. }\end{array}$ \\
\hline 85.05 & $\begin{array}{l}\text { Eletroímãs; ímãs permanentes e artefatos destinados a tornarem-se ímãs permanentes após } \\
\text { magnetização; placas, mandris e dispositivos semelhantes, magnéticos ou eletromagnéticos, de } \\
\text { fixação; acoplamentos, embreagens, variadores de velocidade e freios, eletromagnéticos; cabeças } \\
\text { de elevação eletromagnéticas. }\end{array}$ \\
\hline 85.06 & \begin{tabular}{l} 
Pilhas e baterias de pilhas, elétricas. \\
\hline
\end{tabular}
\end{tabular}




\begin{tabular}{|c|c|}
\hline 85.07 & Acumuladores elétricos e seus separadores, mesmo de forma quadrada ou retangular. \\
\hline 85.08 & Aspiradores. \\
\hline 85.09 & $\begin{array}{l}\text { Aparelhos eletromecânicos de motor elétrico incorporado, de uso doméstico, exceto os aspiradores } \\
\text { da posição } 85.08 \text {. }\end{array}$ \\
\hline 85.10 & $\begin{array}{l}\text { Aparelhos ou máquinas de barbear, máquinas de cortar o cabelo ou de tosquiar e aparelhos de } \\
\text { depilar, de motor elétrico incorporado. }\end{array}$ \\
\hline 85.11 & $\begin{array}{l}\text { Aparelhos e dispositivos elétricos de ignição ou de arranque para motores de ignição por centelha } \\
\text { ou por compressão (por exemplo, magnetos, dínamos-magnetos, bobinas de ignição, velas de } \\
\text { ignição ou de aquecimento, motores de arranque); geradores (dínamos e alternadores, por } \\
\text { exemplo) e conjuntores-disjuntores utilizados com estes motores. }\end{array}$ \\
\hline 85.12 & $\begin{array}{l}\text { Aparelhos elétricos de iluminação ou de sinalização (exceto os da posição 85.39), limpadores de } \\
\text { pára-brisas, degeladores e desembaçadores (desembaciadores) elétricos, dos tipos utilizados em } \\
\text { ciclos e automóveis. }\end{array}$ \\
\hline 85.13 & $\begin{array}{l}\text { Lanternas elétricas portáteis destinadas a funcionar por meio de sua própria fonte de energia (por } \\
\text { exemplo, de pilhas, de acumuladores, de magnetos), excluídos os aparelhos de iluminação da } \\
\text { posição } 85.12 \text {. }\end{array}$ \\
\hline 85.14 & $\begin{array}{l}\text { Fornos elétricos industriais ou de laboratório, incluídos os que funcionam por indução ou por perdas } \\
\text { dielétricas; outros aparelhos industriais ou de laboratório para tratamento térmico de matérias por } \\
\text { indução ou por perdas dielétricas. }\end{array}$ \\
\hline 85.15 & $\begin{array}{l}\text { Máquinas e aparelhos para soldar (mesmo de corte) elétricos (incluídos os a gás aquecido } \\
\text { eletricamente), a "laser" ou outros feixes de luz ou de fótons, a ultra-som, a feixes de elétrons, a } \\
\text { impulsos magnéticos ou a jato de plasma; máquinas e aparelhos elétricos para projeção a quente } \\
\text { de metais ou de ceramais ("cermets"). }\end{array}$ \\
\hline 85.16 & $\begin{array}{l}\text { Aquecedores elétricos de água, incluídos os de imersão; aparelhos elétricos para aquecimento de } \\
\text { ambientes, do solo ou para usos semelhantes; aparelhos eletrotérmicos para arranjos do cabelo } \\
\text { (por exemplo, secadores de cabelo, frisadores, aquecedores de ferros de frisar) ou para secar as } \\
\text { mãos; ferros elétricos de passar; outros aparelhos eletrotérmicos para uso doméstico; resistências } \\
\text { de aquecimento, exceto as da posição } 85.45 .\end{array}$ \\
\hline 85.17 & $\begin{array}{l}\text { Aparelhos telefônicos, incluídos os telefones para redes celulares e para outras redes sem fio; } \\
\text { outros aparelhos para transmissão ou recepção de voz, imagens ou outros dados, incluídos os } \\
\text { aparelhos para comunicação em redes por fio ou redes sem fio (tal como um rede local (LAN) ou } \\
\text { uma rede de área estendida (WAN)), exceto os aparelhos das posições } 84.43,85.25,85.27 \text { ou } \\
85.28 \text {. }\end{array}$ \\
\hline 85.18 & $\begin{array}{l}\text { Microfones e seus suportes; alto-falantes, mesmo montados nos seus receptáculos; fones de } \\
\text { ouvido, mesmo combinados com um microfone, e conjuntos ou sortidos constituídos por um } \\
\text { microfone e um ou mais alto-falantes; amplificadores elétricos de audiofreqüência; aparelhos } \\
\text { elétricos de amplificação de som. }\end{array}$ \\
\hline 85.19 & $\begin{array}{l}\text { Aparelhos de gravação de som; aparelhos de reprodução de som; aparelhos de gravação e de } \\
\text { reprodução de som. }\end{array}$ \\
\hline 85.21 & $\begin{array}{l}\text { Aparelhos videofônicos de gravação ou de reprodução, mesmo incorporando um receptor de sinais } \\
\text { videofônicos. }\end{array}$ \\
\hline 85.22 & $\begin{array}{l}\text { Partes e acessórios reconhecíveis como sendo exclusiva ou principalmente destinados aos } \\
\text { aparelhos das posições } 85.19 \text { a } 85.21 \text {. }\end{array}$ \\
\hline
\end{tabular}




\begin{tabular}{|c|c|}
\hline 85.23 & $\begin{array}{l}\text { Discos, fitas, dispositivos de armazenamento não-volátil de dados à base de semicondutores, } \\
\text { "cartões inteligentes" ("smart cards") e outros suportes para gravação de som ou para gravações } \\
\text { semelhantes, mesmo gravados, incluídos as matrizes e moldes galvânicos para fabricação de } \\
\text { discos, exceto os produtos do Capítulo } 37 \text {. }\end{array}$ \\
\hline 85.25 & $\begin{array}{l}\text { Aparelhos transmissores (emissores) para radiodifusão ou televisão, mesmo incorporando um } \\
\text { aparelho receptor ou um aparelho de gravação ou de reprodução de som; câmeras de televisão, } \\
\text { câmeras fotográficas digitais e câmeras de vídeo. }\end{array}$ \\
\hline 85.26 & $\begin{array}{l}\text { Aparelhos de radiodetecção e de radiossondagem (radar), aparelhos de radionavegação e } \\
\text { aparelhos de radiotelecomando. }\end{array}$ \\
\hline 85.27 & $\begin{array}{l}\text { Aparelhos receptores para radiodifusão, mesmo combinados num mesmo invólucro, com um } \\
\text { aparelho de gravação ou de reprodução de som, ou com um relógio. }\end{array}$ \\
\hline 85.28 & $\begin{array}{l}\text { Monitores e projetores, que não incorporem aparelho receptor de televisão; aparelhos receptores } \\
\text { de televisão, mesmo que incorporem um aparelho receptor de radiodifusão ou um aparelho de } \\
\text { gravação ou de reprodução de som ou de imagens. }\end{array}$ \\
\hline 85.29 & $\begin{array}{l}\text { Partes reconhecíveis como exclusiva ou principalmente destinadas aos aparelhos das posições } \\
85.25 \text { a } 85.28 \text {. }\end{array}$ \\
\hline 85.30 & $\begin{array}{l}\text { Aparelhos elétricos de sinalização (excluindo os de transmissão de mensagens), de segurança, de } \\
\text { controle e de comando, para vias férreas ou semelhantes, vias terrestres ou fluviais, para áreas ou } \\
\text { parques de estacionamento, instalações portuárias ou para aeródromos (exceto os da posição } \\
\text { 86.08). }\end{array}$ \\
\hline 85.31 & $\begin{array}{l}\text { Aparelhos elétricos de sinalização acústica ou visual (por exemplo, campainhas, sirenes, quadros } \\
\text { indicadores, aparelhos de alarme para proteção contra roubo ou incêndio), exceto os das posições } \\
85.12 \text { ou } 85.30 \text {. }\end{array}$ \\
\hline 85.32 & Condensadores elétricos, fixos, variáveis ou ajustáveis. \\
\hline 85.33 & Resistências elétricas (incluídos os reostatos e os potenciômetros), exceto de aquecimento. \\
\hline 8534 & Circuitos impressos. \\
\hline 85.35 & $\begin{array}{l}\text { Aparelhos para interrupção, seccionamento, proteção, derivação, ligação ou conexão de circuitos } \\
\text { elétricos (por exemplo, interruptores, comutadores, corta-circuitos, pára-raios, limitadores de } \\
\text { tensão, eliminadores de onda, tomadas de corrente e outros conectores, caixas de junção), para } \\
\text { tensão superior a } 1.000 \mathrm{~V} \text {. }\end{array}$ \\
\hline 85.36 & $\begin{array}{l}\text { Aparelhos para interrupção, seccionamento, proteção, derivação, ligação ou conexão de circuitos } \\
\text { elétricos (por exemplo, interruptores, comutadores, relés, corta-circuitos, eliminadores de onda, } \\
\text { plugues e tomadas de corrente, suportes para lâmpadas e outros conectores, caixas de junção), } \\
\text { para uma tensão não superior a 1.000V; conectores para fibras ópticas, feixes ou cabos de fibras } \\
\text { ópticas. }\end{array}$ \\
\hline 85.37 & $\begin{array}{l}\text { Quadros, painéis, consoles, cabinas, armários e outros suportes com dois ou mais aparelhos das } \\
\text { posições } 85.35 \text { ou } 85.36 \text {, para comando elétrico ou distribuição de energia elétrica, incluídos os que } \\
\text { incorporem instrumentos ou aparelhos do Capítulo } 90 \text {, bem como os aparelhos de comando } \\
\text { numérico, exceto os aparelhos de comutação da posição } 85.17 \text {. }\end{array}$ \\
\hline 85.38 & $\begin{array}{l}\text { Partes reconhecíveis como exclusiva ou principalmente destinadas aos aparelhos das posições } \\
85.35,85.36 \text { ou } 85.37 \text {. }\end{array}$ \\
\hline 85.39 & $\begin{array}{l}\text { Lâmpadas e tubos elétricos de incandescência ou de descarga, incluídos os artigos denominados } \\
\text { "faróis e projetores, em unidades seladas" e as lâmpadas e tubos de raios ultravioleta ou } \\
\text { infravermelhos; lâmpadas de arco. }\end{array}$ \\
\hline
\end{tabular}




\begin{tabular}{|c|c|}
\hline 85.40 & $\begin{array}{l}\text { Lâmpadas, tubos e válvulas, eletrônicos, de cátodo quente, cátodo frio ou fotocátodo (por exemplo, } \\
\text { lâmpadas, tubos e válvulas, de vácuo, de vapor ou de gás, ampolas retificadoras de vapor de } \\
\text { mercúrio, tubos catódicos, tubos e válvulas para câmeras de televisão), exceto os da posição } \\
\text { 85.39. }\end{array}$ \\
\hline 85.41 & $\begin{array}{l}\text { Diodos, transistores e dispositivos semelhantes semicondutores; dispositivos fotossensíveis } \\
\text { semicondutores, incluídas as células fotovoltaicas, mesmo montadas em módulos ou em painéis; } \\
\text { diodos emissores de luz; cristais piezelétricos montados. }\end{array}$ \\
\hline 85.42 & Circuitos integrados eletrônicos. \\
\hline 85.43 & $\begin{array}{l}\text { Máquinas e aparelhos elétricos com função própria, não especificados nem compreendidos em } \\
\text { outras posições do presente Capítulo. }\end{array}$ \\
\hline 85.44 & $\begin{array}{l}\text { Fios, cabos (incluídos os cabos coaxiais) e outros condutores, isolados para usos elétricos } \\
\text { (incluídos os envernizados ou oxidados anodicamente), mesmo com peças de conexão; cabos de } \\
\text { fibras ópticas, constituídos de fibras embainhadas individualmente, mesmo com condutores } \\
\text { elétricos ou munidos de peças de conexão. }\end{array}$ \\
\hline 85.45 & $\begin{array}{l}\text { Eletrodos de carvão, escovas de carvão, carvões para lâmpadas ou para pilhas e outros artigos de } \\
\text { grafita ou de carvão, com ou sem metal, para usos elétricos. }\end{array}$ \\
\hline 85.46 & Isoladores de qualquer matéria, para usos elétricos. \\
\hline 85.47 & $\begin{array}{l}\text { Peças isolantes inteiramente de matérias isolantes, ou com simples peças metálicas de montagem } \\
\text { (suportes roscados, por exemplo) incorporadas na massa, para máquinas, aparelhos e instalações } \\
\text { elétricas, exceto os isoladores da posição } 85.46 \text {; tubos isoladores e suas peças de ligação, de } \\
\text { metais comuns, isolados interiormente. }\end{array}$ \\
\hline 85.48 & $\begin{array}{l}\text { Desperdícios e resíduos de pilhas, de baterias de pilhas e de acumuladores, elétricos; pilhas, } \\
\text { baterias de pilhas e acumuladores, elétricos, inservíveis; partes elétricas de máquinas e aparelhos, } \\
\text { não especificadas nem compreendidas em outras posições do presente Capítulo. }\end{array}$ \\
\hline
\end{tabular}

Fonte: Retirado de Ministério de Desenvolvimento, Indústria e Comércio. Comércio Exterior - Estatísticas de comércio exterior. Disponível em: http://www.mdic.gov.br/sitio/interna/interna.php?area=5\&menu=1095 


\section{Dados de produção e valor adicionado}

Tabela 8: Valor adicionado e indicadores de relacionados por indústria, a preços correntes, anos selecionados

\begin{tabular}{|c|c|c|c|c|c|c|c|c|}
\hline \multirow{3}{*}{$\begin{array}{c}\text { Indústria } \\
\text { (ISIC Revisão 3) }\end{array}$} & \multicolumn{8}{|c|}{ Valor adicionado } \\
\hline & \multicolumn{2}{|c|}{$\begin{array}{c}\text { At factor values } \\
\text { (em milhões de US\$) }\end{array}$} & \multicolumn{2}{|c|}{$\begin{array}{c}\text { Participação na } \\
\text { produção } \\
\text { (em \%) }\end{array}$} & \multicolumn{2}{|c|}{$\begin{array}{l}\text { Por empregado } \\
\text { (em US\$) }\end{array}$} & \multicolumn{2}{|c|}{$\begin{array}{l}\text { Participação na } \\
\text { indústria de } \\
\text { manufatura } \\
\text { (em \%) }\end{array}$} \\
\hline & 2000 & 2007 & 2000 & 2007 & 2000 & 2007 & 2000 & 2007 \\
\hline Máquinas de uso geral & 3,294 & 7,568 & 50 & 42 & 23494 & 39957 & 2.5 & 2.6 \\
\hline $\begin{array}{lll}\text { Máquinas } & \text { para } & \text { uso } \\
\text { específico } & & \\
\end{array}$ & 2,919 & 9,508 & 47 & 45 & 20420 & 36032 & 2.2 & 3.3 \\
\hline Subtotal & 6,213 & 17,076 & 97 & 87 & 43914 & 75989 & 0 & 0 \\
\hline $\begin{array}{l}\text { Total indústria de } \\
\text { manufatura }\end{array}$ & 131,364 & 286,654 & 45 & 42 & 25650 & 40908 & 100.0 & 100.0 \\
\hline
\end{tabular}

Fonte: Statistical Country Briefs. UNIDO. An asterisk (*) next to the year denotes estimated figures.

Disponível em: http://www.unido.org/index.php?id=1000313. 


\section{ANEXO B - LISTA GERAL DE EMPRESAS E GRUPOS DE PESQUISA IDENTIFICADOS PARA A PESQUISA EMPÍRICA}

\section{Lista completa de empresas de máquinas-ferramentas}

\begin{tabular}{|c|c|c|c|c|c|c|c|c|c|c|}
\hline & \multirow[b]{2}{*}{ Empresas } & \multirow[b]{2}{*}{$\begin{array}{c}\text { Origem da } \\
\text { matriz }\end{array}$} & \multirow[b]{2}{*}{$\begin{array}{l}\text { Localização } \\
\text { da unidade } \\
\text { produtiva }\end{array}$} & \multicolumn{2}{|c|}{ ABIMAQ } & \multirow{2}{*}{$\begin{array}{c}\text { Grupos } \\
\text { CNPQ } \\
\\
\text { Interação } \\
\text { realizada com } \\
\text { grupos de } \\
\text { pesquisa }\end{array}$} & \multirow{2}{*}{$\begin{array}{c}\begin{array}{c}\text { Valor } \\
\text { Econômico }\end{array} \\
\text { Maiores } \\
\text { grupos } \\
\text { (2010 e 2009) }\end{array}$} & \multicolumn{2}{|c|}{$\begin{array}{l}\text { Exame Maiores e Melhores - } \\
\text { BK }\end{array}$} & \multirow{2}{*}{$\begin{array}{c}\text { Seade } \\
\text { Investimentos } \\
\text { anunciados } \\
\text { no setor de } \\
\text { máquinas e } \\
\text { equipamentos } \\
\text { - Estado de } \\
S P(2010)\end{array}$} \\
\hline & & & & $\begin{array}{l}\text { Produtos } \\
\text { utilizados } \\
\text { em } \\
\text { processos } \\
\text { de } \\
\text { usinagem }\end{array}$ & $\begin{array}{l}\text { Associado } \\
\text { s CSMF }\end{array}$ & & & $\begin{array}{c}\text { Maiores } \\
\text { empresas em } \\
\text { vendas (2010 } \\
\text { e 2009) }\end{array}$ & $\begin{array}{c}\text { Melhores } \\
\text { empresas } \\
\text { (2010 e 2009) }\end{array}$ & \\
\hline \multicolumn{11}{|c|}{ Empresas de máquinas-ferramentas analisadas na pesquisa empírica: } \\
\hline 1 & $\begin{array}{l}\text { B. Grob do } \\
\text { Brasil S/A }\end{array}$ & Alemanha & $\begin{array}{l}\text { São } \\
\text { Bernardo do } \\
\text { Campo/SP }\end{array}$ & $\mathbf{x}$ & & & & & & \\
\hline 2 & $\begin{array}{l}\text { D.R. Promaq } \\
\text { indústria e } \\
\text { comércio Ltda }\end{array}$ & Brasil & $\begin{array}{l}\text { São } \\
\text { Bernardo do } \\
\text { Campo/SP }\end{array}$ & $\mathbf{x}$ & & & & & & \\
\hline 3 & $\begin{array}{l}\text { Ergomat } \\
\text { indústria e } \\
\text { comércio } \\
\text { Ltda. }\end{array}$ & Brasil & $\begin{array}{l}\text { São } \\
\text { Paulo/SP }\end{array}$ & $\mathbf{x}$ & $\mathbf{x}$ & & & & & \\
\hline 4 & $\begin{array}{l}\text { Ferdimat } \\
\text { indústria e } \\
\text { comércio de } \\
\text { maqs. } \\
\text { Operatrizes } \\
\text { Ltda }\end{array}$ & Brasil & $\begin{array}{l}\text { São José dos } \\
\text { Campos/SP }\end{array}$ & $\mathbf{x}$ & & & & & & \\
\hline 5 & $\begin{array}{l}\text { Index tornos } \\
\text { automáticos } \\
\text { ind. E com. } \\
\text { Ltda }\end{array}$ & Alemanha & Sorocaba/SP & $\mathbf{x}$ & & $\mathbf{X}$ & & & & \\
\hline 6 & $\begin{array}{l}\text { Indústrias } \\
\text { Romi }\end{array}$ & Brasil & $\begin{array}{l}\text { Santa } \\
\text { Bárbara } \\
\text { D'Oeste/SP }\end{array}$ & $\mathbf{x}$ & $\mathbf{x}$ & $\mathbf{X}$ & $\mathbf{X}$ & $\mathbf{X}$ & $\mathbf{x}$ & $\mathbf{x}$ \\
\hline \multicolumn{11}{|c|}{ Empresas de máquinas-ferramentas que não puderam colaborar com a pesquisa empírica } \\
\hline & $\begin{array}{l}\text { Heller } \\
\text { Máquinas } \\
\text { operatrizes } \\
\text { Ind. E Com. } \\
\text { Ltda }\end{array}$ & Alemanha & Sorocaba/SP & $\mathbf{x}$ & $\mathbf{x}$ & & & & & \\
\hline & $\begin{array}{c}\text { Indústria de } \\
\text { Máquinas } \\
\text { Operatrizes } \\
\text { Zema Zselics } \\
\text { Ltda }\end{array}$ & Brasil & $\begin{array}{l}\text { São } \\
\text { Bernardo do } \\
\text { Campo/SP }\end{array}$ & $\mathbf{x}$ & & $\mathbf{X}$ & & & & \\
\hline & $\begin{array}{l}\text { Indústrias } \\
\text { Nardini }\end{array}$ & Brasil & $\begin{array}{l}\text { Americana/S } \\
\mathrm{P}\end{array}$ & $\mathbf{x}$ & & & & & & \\
\hline
\end{tabular}




\begin{tabular}{|l|l|l|l|l|l|l|l|}
\hline $\begin{array}{l}\text { Máquinas } \\
\text { operatrizes } \\
\text { Zocca Ltda. }\end{array}$ & Brasil & $\begin{array}{l}\text { Jaboticaba/S } \\
\text { P }\end{array}$ & $\mathbf{X}$ & & & \\
\hline $\begin{array}{l}\text { TM Bevo ind. } \\
\begin{array}{l}\text { E com. De } \\
\text { máquinas } \\
\text { operatrizes } \\
\text { Ltda }\end{array}\end{array}$ & Alemanha & $\begin{array}{l}\text { São } \\
\text { Bernardo do } \\
\text { Campo/SP }\end{array}$ & $\mathbf{X}$ & $\mathbf{X}$ & & & \\
\hline
\end{tabular}

Fonte: Elaboração própria. 


\section{ANEXO C - QUESTIONÁRIO UTILIZADO NA PESQUISA EMPÍRICA}

\section{Questionários aplicado em empresas de máquinas-ferramenta}

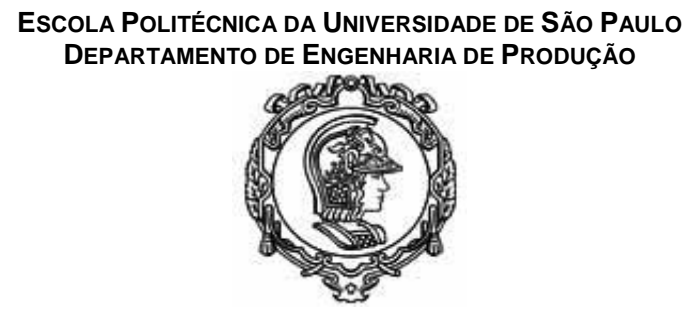

QUESTÕES APLICADAS EM EMPRESAS DE MÁQUINAS-FERRAMENTA

DATA DE REALIZAÇÃo DA ENTREVISTA:

HORÁRIO DA ENTREVISTA: Início: ; Fim:

Identificação do entrevistado e de sua trajetória na empresa

Nome:

Área de atuação:

Cargo:

Tempo de empresa:

Formação:

\section{I) IDENTIFICAÇÃo E CARACTERÍSTICA DA EMPRESA INVESTIGADA}

Dados Gerais da empresa investigada

Nome fantasia:

Ano de fundação:

Origem de capital:

Atividades principais

(linha de produtos):

Dados sobre as unidades de produção:

Número e localização das unidades no Brasil

Número e localização das unidades no exterior: 
Capacidade de produção anual (volumes):

Nível atual de utilização da capacidade produtiva (\%):

Número de turnos trabalhados:

II) Produto e vendas

1. Descrição das linhas de produtos:

\begin{tabular}{|l|l|l|l|l|l|}
\hline $\begin{array}{c}\text { Linha de } \\
\text { produtos }\end{array}$ & $\begin{array}{c}\text { Principais } \\
\text { produtos }\end{array}$ & $\begin{array}{c}\text { Idade média } \\
\text { das linhas de } \\
\text { produtos }\end{array}$ & $\begin{array}{c}\text { Tem departamento } \\
\text { de projeto interno } \\
\text { (sim/não) }\end{array}$ & $\begin{array}{c}\text { Participação no } \\
\text { faturamento } \\
(\%)\end{array}$ & $\begin{array}{c}\text { Investimentos } \\
\text { (\%) }\end{array}$ \\
\hline & & & & & \\
\hline
\end{tabular}

2. Divisão das vendas entre as quatro principais linhas de produtos (mercado interno e externo):

\begin{tabular}{|l|c|c|c|}
\hline $\begin{array}{c}\text { Linha de } \\
\text { produtos }\end{array}$ & $\begin{array}{c}\text { Participação das vendas no } \\
\text { mercado interno } \\
(\%)\end{array}$ & $\begin{array}{c}\text { Participação das vendas no } \\
\text { mercado externo } \\
(\%)\end{array}$ & \begin{tabular}{c} 
Mercados \\
\hline
\end{tabular} \\
\hline
\end{tabular}

3. A empresa terceirizou (ou terceiriza) alguma atividade/etapa da produção? Por quê?

4. Quais os principais setores de utilização das máquinas-ferramenta no mercado interno e externo?

\begin{tabular}{|c|c|c|}
\hline \multirow{2}{*}{ Produtos } & \multicolumn{2}{|c|}{ Setores de aplicação (clientes) } \\
\hline & Mercado interno & Mercado externo \\
\hline & & \\
\hline & & \\
\hline & & \\
\hline & & \\
\hline
\end{tabular}

5. Quais os principais requisitos (demandas) dos setores de aplicação usuários das máquinas-ferramenta no mercado externo e externo?

\begin{tabular}{|l|l|l|}
\hline \multirow{2}{*}{$\begin{array}{c}\text { Setores de aplicação } \\
\text { (clientes) }\end{array}$} & \multicolumn{2}{|c|}{$\begin{array}{c}\text { Demandas dos setores de aplicação } \\
\text { em relação às MFs da empresa }\end{array}$} \\
\cline { 2 - 4 } & Mercado interno & \multicolumn{2}{|c|}{ Mercado externo } \\
\hline & & \\
\hline & & \\
\hline & & \\
\hline & & \\
\hline & & \\
\hline
\end{tabular}


6. Como a empresa classifica a sua relação com os setores usuários das máquinas-ferramenta?

\begin{tabular}{l}
\begin{tabular}{|c|c|c|c|}
\hline 1.Compra sistemática & 2.Compra recorrente & $\begin{array}{c}\text { 3.Compra e cooperação } \\
\text { técnica sistemática }\end{array}$ & $\begin{array}{c}\text { 4.Compra e cooperação } \\
\text { técnica recorrente }\end{array}$ \\
\hline $\begin{array}{c}\text { Setores usuários das máquinas- } \\
\text { ferramenta }\end{array}$ & $\begin{array}{c}\text { Classificação } \\
(1-4)\end{array}$ & Justificativa \\
\hline & & \\
\hline & &
\end{tabular} \\
\hline
\end{tabular}

III) CARACTERÍSTICAS DA DINÂMICA CONCORRENCIAL

7. Quais fatores relacionados aos produtos/processos são mais importantes para a competitividade da empresa no mercado interno? (1 a 4)

\begin{tabular}{|l|l|l|l|}
\hline \multicolumn{1}{|c|}{ 1.Sem importância } & 2. Pouco importante & $\begin{array}{c}\text { 3.Moderadamente } \\
\text { importante }\end{array}$ & 4.Muito importante \\
\hline Fator de competitividade & $\begin{array}{c}\text { Nota } \\
(\mathbf{1 - 4})\end{array}$ & & Justificativa \\
\hline Custo & & & \\
\hline Projeto de produto & & & \\
\hline Qualidade & & \\
\hline Flexibilidade & & \\
\hline Produtividade & & \\
\hline Assistência técnica para outros & & \\
\hline $\begin{array}{l}\text { Utilização para } \\
\text { materiais }\end{array}$ & & \\
\hline Outro - qual & & \\
\hline
\end{tabular}

8. Quais fatores relacionados aos produtos/processos são mais importantes para a competitividade da empresa no mercado externo (inclusive América Latina)? (1 a 4)

\begin{tabular}{|c|c|c|c|}
\hline 1.Sem importância & 2. Pouco importante & $\begin{array}{c}\text { 3.Moderadamente } \\
\text { importante }\end{array}$ & 4.Muito importante \\
\hline
\end{tabular}

\begin{tabular}{|l|l|l|}
\hline \multicolumn{1}{|c|}{ Fator de competitividade } & $\begin{array}{l}\text { Nota } \\
(1-4)\end{array}$ & \\
\hline Custo & & \\
\hline Projeto de produto & & \\
\hline Qualidade & & \\
\hline Flexibilidade & & \\
\hline Produtividade & & \\
\hline Assistência técnica & & \\
\hline Utilização para novos materiais & & \\
\hline Outro- qual? & & \\
\hline
\end{tabular}

\section{Quais os principais concorrentes da empresa no mercado interno e externo}

\begin{tabular}{|l|l|}
\hline \multicolumn{2}{|c|}{ Concorrentes da empresa de máquinas-ferramenta } \\
\hline Mercado interno & Mercado externo \\
\hline & \\
\hline & \\
\hline
\end{tabular}




\section{IV) Vetores do Desenvolvimento técnico no Ramo de Máquinas-FerRamenta}

\section{CARACTERÍSTICAS GERAIS}

10. Em sua opinião, quais foram as inovações mais importantes (produto e processo) dos últimos anos no setor em que a empresa atua?

11. Quais foram os impactos dessas inovações para a atuação da empresa no mercado (Brasil e mundo)?

12. Como a empresa caracteriza a natureza do desenvolvimento tecnológico interno (explique):

a) Produto - radical ou incremental ou ambos:

b) Processo - radical ou incremental ou ambos:

13. O conhecimento técnico de produtos (tarefas cotidianas) é:

\begin{tabular}{|l|l|l|}
\hline \multicolumn{2}{|c|}{ Parâmetros de conhecimento técnico de produtos } & Resposta \\
\hline Especialização & Especializado ou diversificado & \\
\hline Domínio & Base Cientifica e tecnológica & \\
\hline Grau de acessibilidade & Aberto ou fechado & \\
\hline
\end{tabular}

14. O conhecimento técnico de processos (tarefas cotidianas) é:

\begin{tabular}{|l|l|l|}
\hline \multicolumn{2}{|c|}{ Parâmetros de conhecimento técnico de processos } & Resposta \\
\hline Especialização & Especializado ou diversificado & \\
\hline Domínio & Cientifico e tecnológico & \\
\hline Grau de acessibilidade & Aberto ou fechado & \\
\hline
\end{tabular}

15. Qual o tempo médio (meses, anos) que a empresa leva para criar um novo produto? E para alterar as características (incrementais) de produtos e dos processos (atualização)?

16. Os elementos listados a seguir são importantes para o desenvolvimento e melhorias das máquinas? Há um trade-offs na decisão (escolha) de algum desses elementos?

\begin{tabular}{l|l|c|c|} 
1.Sem importância & 2. Pouco importante & $\begin{array}{c}\text { 3.Moderadamente } \\
\text { importante }\end{array}$ & 4.Muito importante \\
\hline
\end{tabular}

Fatores importantes para o desenvolvimento das máquinas 


\begin{tabular}{|l|l|l|}
\hline $\begin{array}{l}\text { Características do uso da máquina } \\
\text { (velocidade, flexibilidade, precisão de } \\
\text { corte) }\end{array}$ & & \\
\hline Experiências tácitas no projeto & & \\
\hline $\begin{array}{l}\text { Experiências tácitas no uso de } \\
\text { equipamentos }\end{array}$ & & \\
\hline $\begin{array}{l}\text { Interface entre controles eletrônicos } \\
\text { e mecânicos }\end{array}$ & & \\
\hline $\begin{array}{l}\text { Interface entre elementos estruturais, } \\
\text { de controle e de transmissão }\end{array}$ & & \\
\hline Outros & & \\
\hline
\end{tabular}

\section{ÁREAS DE CONHECIMENTO}

17. Qual a importância das áreas de conhecimento listadas a seguir para o desenvolvimento e melhorias das máquinas (dê um exemplo de produtos em cada área)?

\begin{tabular}{|c|c|c|c|c|}
\hline 1.Sem importância & \multicolumn{2}{|c|}{ 2. Pouco importante } & $\begin{array}{l}\text { 3.Moderadamente } \\
\text { importante }\end{array}$ & 4.Muito importante \\
\hline $\begin{array}{c}\text { Áreas de } \\
\text { conhecimento }\end{array}$ & $\begin{array}{c}\text { Notas } \\
(1-4)\end{array}$ & \multicolumn{3}{|c|}{$\begin{array}{c}\text { Contribuições da área para o desenvolvimento (ou melhorias) das } \\
\text { MFs da empresa (exemplos) }\end{array}$} \\
\hline \multicolumn{5}{|l|}{ Produção: } \\
\hline \multicolumn{5}{|l|}{ Mecânica: } \\
\hline \multirow{2}{*}{\multicolumn{5}{|c|}{ Eletrônica: }} \\
\hline & & & & \\
\hline \multicolumn{5}{|l|}{ Mecatrônica: } \\
\hline \multicolumn{5}{|l|}{ Outras (quais) } \\
\hline & & & & \\
\hline
\end{tabular}

18. Quais os fatores determinantes (motivador) para a empresa incorporar os conhecimentos dessas áreas à sua linha de produtos? (1-4)

\begin{tabular}{|c|c|c|c|}
\hline 1.Sem importância & 2. Pouco importante & $\begin{array}{c}\text { 3.Moderadamente } \\
\text { importante }\end{array}$ & 4.Muito importante \\
\hline
\end{tabular}

\begin{tabular}{|l|l|l|}
\hline \multicolumn{1}{|c|}{ Fatores determinantes } & \multicolumn{1}{|c|}{$\begin{array}{c}\text { Notas } \\
(\mathbf{1 - 4})\end{array}$} & \\
\hline $\begin{array}{l}\text { Alterações nas características } \\
\text { dos materiais (mercado) }\end{array}$ & & \\
\hline $\begin{array}{l}\text { Alterações nas características } \\
\text { dos materiais (do usuário) }\end{array}$ & & \\
\hline $\begin{array}{l}\text { Atualização das } \\
\text { características técnicas das } \\
\text { máquinas }\end{array}$ & & \\
\hline $\begin{array}{l}\text { Resolução de problemas } \\
\text { técnicos no mercado }\end{array}$ & & \\
\hline Lucro mo mercado & & \\
\hline $\begin{array}{l}\text { Desempenho no } \\
\text { interno }\end{array}$ & & \\
\hline Inserção no mercado externo & & \\
\hline $\begin{array}{l}\text { Desempenho no mono } \\
\text { externo }\end{array}$ & & \\
\hline Outros & & \\
\hline
\end{tabular}

19. A empresa tem passado por alguma reestruturação visando à incorporação de conhecimentos de outras áreas (quais)?

20. Eventuais mudanças nessas áreas de conhecimento representam uma oportunidade ou ameaça para o desenvolvimento das máquinas-ferramenta da empresa? E do setor nacional? Por quê? (cite ao menos um exemplo) 


\section{MATERIAIS E TECNOLOGIAS DE AUTOMACÃO}

21. A empresa apresentou modificações no desenvolvimento das máquinas em virtude de alterações nas características dos materiais empregados? Quais?

\begin{tabular}{|c|c|c|}
\hline Linha de máquinas & Máquinas & Modificações determinadas por novos materiais \\
\hline & & \\
\hline & & \\
\hline & & \\
\hline
\end{tabular}

22. Na última década a empresa investiu no desenvolvimento de tecnologias de automação das máquinasferramenta? Quais os determinantes da decisão de investimento?

Determinantes:

1. Atualização/modernização; 2.Aquisição de nova tecnologia; 3. Outros (quais)

\begin{tabular}{|c|l|l|}
\hline $\begin{array}{c}\text { Tecnologias } \\
\text { (especificar) }\end{array}$ & $\begin{array}{c}\text { Participação no total de } \\
\text { investimentos em } \\
\text { tecnologias (\%) }\end{array}$ & $\begin{array}{c}\text { Determinante dos } \\
\text { investimentos }\end{array}$ \\
\hline & & \\
\hline & & \\
\hline
\end{tabular}

23. Sobre as máquinas com tecnologias CNC:

Característica: 1.Tecnologia nova no mercado interno; 2. Tecnologia nova no mercado externo

\begin{tabular}{|l|l|l|}
\hline Máquinas com CNC & Características & Competências internas necessárias \\
\hline & & \\
\hline & & \\
\hline & & \\
\hline
\end{tabular}

24. Quais foram os principais efeitos das tecnologias para o desempenho da máquina? E da empresa?

\begin{tabular}{|l|l|}
\hline Tecnologias & Efeitos para o desempenho técnico da máquina \\
\hline & \\
\hline & \\
\hline & \\
\hline & \\
\hline
\end{tabular}

\begin{tabular}{|c|c|}
\hline Tecnologias & Efeitos para a competitividade da empresa \\
\hline & \\
\hline & \\
\hline & \\
\hline & \\
\hline
\end{tabular}

\section{PESQUISA, APRENDIZADO E DESENVOLVIMENTO DE MFS}

25. Como a empresa classifica as formas de acessar informações no desenvolvimento ou melhorias nas máquinas-ferramenta?

\begin{tabular}{|l|l|c|c|} 
1.Sem importância & 2. Pouco importante & $\begin{array}{c}\text { 3.Moderadamente } \\
\text { importante }\end{array}$ & 4.Muito importante \\
\hline
\end{tabular}




\begin{tabular}{|l|l|l|}
\hline \multicolumn{1}{|c|}{ Condições } & Nota (1-4) & \\
\hline Aprendizado & & \\
\hline Capacidade organizacional & & \\
\hline Feedback & & \\
\hline Outros fatores & & \\
\hline & & \\
\hline
\end{tabular}

26. Como ocorre a difusão dessas informações no ambiente interno à empresa?

27. Sobre o aprendizado de fontes externas:

1.Sem importância
\begin{tabular}{|l|l|l|}
\hline \multicolumn{1}{|c|}{ 2. Pouco importante } & \multicolumn{1}{c|}{$\begin{array}{c}\text { 3.Moderadamente } \\
\text { importante }\end{array}$} & 4.Muito \\
\hline Fornecedor & Nota (1-4) \\
\hline Usuário & \\
\hline Instituições de pesquisa & \\
\hline Instituições de apoio (teste) & \\
\hline Instituições de formação de RH & \\
\hline Outras fontes (1): & \\
\hline Outras fontes (2): & \\
\hline
\end{tabular}

28. Como ocorre o aprendizado das informações provenientes do ambiente externo à empresa?

\section{V) Regime Tecnológico}

29. As tecnologias embutidas nas máquinas podem ser classificadas como pervasivas (aplicação do conhecimento em variedade de produtos) ou não pervasivas (alta cumulatividade e especialização)? Por quê?

\begin{tabular}{|l|l|l|}
\hline & & Exemplo \\
\hline \multirow{2}{*}{ Tecnologias } & Pervasivas & \\
\cline { 2 - 3 } & Não-pervasivas & \\
\hline
\end{tabular}

30. Os conhecimentos utilizados nas empresas podem ser caracterizados por qual desses níveis de cumulatividade?

\begin{tabular}{|l|l|l|}
\hline & & \multicolumn{1}{|c|}{ Exemplo } \\
\hline \multirow{3}{*}{ Cumulatividade } & Nível individual & \\
\cline { 2 - 3 } & Nível da firma & \\
\cline { 2 - 3 } & Nível organizacional & \\
\hline
\end{tabular}


31. A empresa considera que o setor de MFs apresenta alta ou baixa oportunidade para o desenvolvimento de MFs? Por quê?

32. Sobre os instrumentos de proteção das informações, quais os mais usados pela empresa? Eles são eficazes? Há dificuldades (quais)?

\begin{tabular}{|l|l|l|}
\hline \multirow{2}{*}{$\begin{array}{c}\text { Mecanismos de proteção das } \\
\text { informações }\end{array}$} & \multicolumn{2}{|c|}{ Produto } \\
\cline { 2 - 4 } & $\begin{array}{c}\text { Eficácia } \\
\text { (sim/não) }\end{array}$ & (dificuldade alta, média ou baixa) \\
\hline Defasagem temporal & & \\
\hline Complexidade & & \\
\hline Aprendizado & & \\
\hline Lead time & & \\
\hline Curva de aprendizado & & \\
\hline Custo e tempo requerido & & \\
\hline Canais de comercialização & & \\
\hline Outros mecanismos & & \\
\hline & & \\
\hline
\end{tabular}

\begin{tabular}{|c|c|c|}
\hline \multirow{2}{*}{$\begin{array}{c}\text { Mecanismos de proteção das } \\
\text { informações }\end{array}$} & \multicolumn{2}{|c|}{ Processo } \\
\hline & $\begin{array}{l}\text { Eficácia } \\
\text { (sim/não) }\end{array}$ & $\begin{array}{c}\text { Dificuldades } \\
\text { (dificuldade alta, media ou baixa) }\end{array}$ \\
\hline \multicolumn{3}{|l|}{ Defasagem temporal } \\
\hline \multicolumn{3}{|l|}{ Complexidade } \\
\hline \multicolumn{3}{|l|}{ Aprendizado } \\
\hline \multicolumn{3}{|l|}{ Lead time } \\
\hline \multicolumn{3}{|l|}{ Curva de aprendizado } \\
\hline \multicolumn{3}{|l|}{ Custo e tempo requerido } \\
\hline \multicolumn{3}{|l|}{ Canais de comercialização } \\
\hline Outros mecanismos & & \\
\hline & & \\
\hline
\end{tabular}

33. A empresa depositou alguma patente referente à mudança tecnológica nos seus produtos ou processos? Sim (1); Não (2).

No Brasil?

Sim (1); Não (2). Quantas e quais?

No exterior?

Sim (1); Não (2). Quantas e quais?

34. A empresa realizou algum pagamento referente às mudanças tecnológicas ou organizacionais recentes em seus produtos ou processos? Sim (1) Não (2)

Modalidade 


\begin{tabular}{|l|l|}
\hline & \\
\hline Valor & \\
\hline & \\
\hline & \\
\hline
\end{tabular}

35. A empresa recebeu algum pagamento referente às mudanças tecnológicas ou organizacionais recentes em seus produtos ou processos? Sim (1) Não (2)

\begin{tabular}{|l|l|}
\hline Modalidade & \\
\hline & \\
\hline & \\
\hline Valor & \\
\hline & \\
\hline
\end{tabular}

\section{VI) SISTEMA SETORIAL DE MÁQUINAS-FERRAMENTA}

\section{CARACTERÍSTICAS GERAIS}

36. Há colaboração dos atores citados a seguir para o desenvolvimento de produtos e melhorias das máquinas? (Dê exemplos)

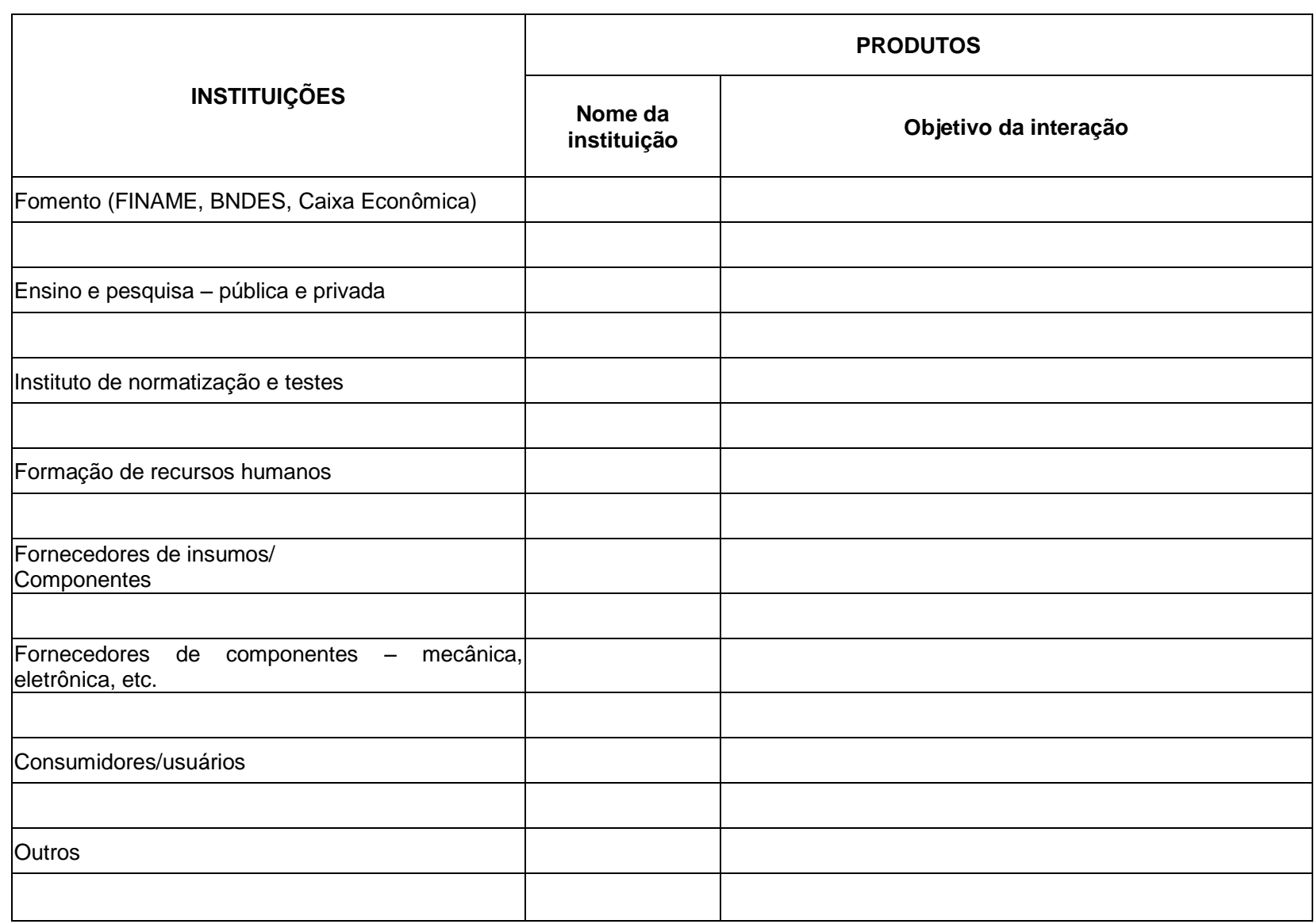

37. Há colaboração dos atores citados a seguir para o desenvolvimento e melhoria dos processos (Dê exemplo).

\begin{tabular}{|l|l|l|}
\hline \multirow{2}{*}{ INSTITUIÇÕES } & \multicolumn{2}{|c|}{ PROCESSOS /TECNOLOGIAS } \\
\cline { 2 - 3 } & $\begin{array}{c}\text { Nome da } \\
\text { instituição }\end{array}$ & Objetivo da interação \\
\hline
\end{tabular}




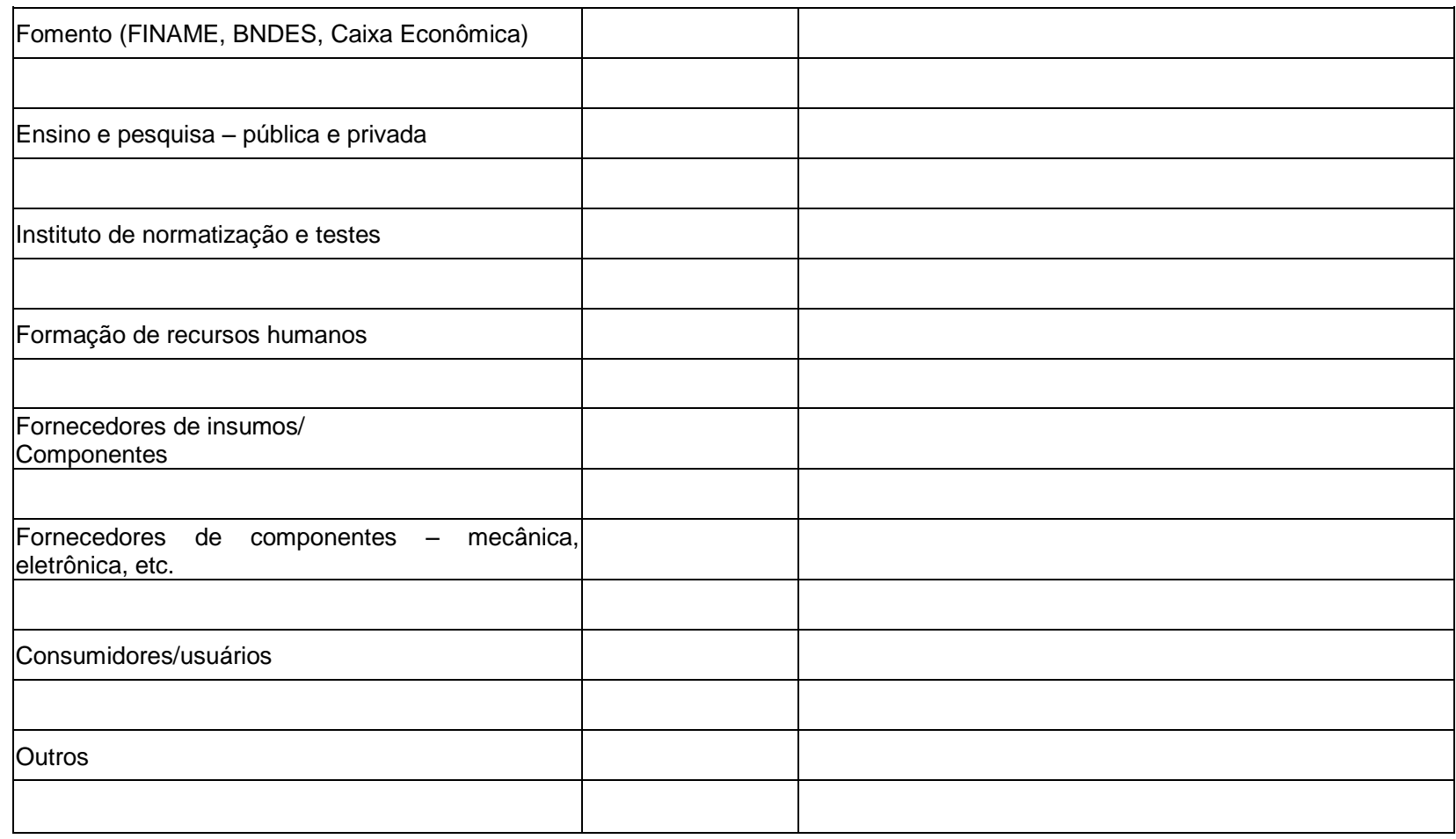

\section{INTERACÃO ENTRE EMPRESA, UNIVERSIDADE E INSTITUTOS DE PESQUISA}

38. Quais as razões da interação empresa-universidade e Institutos de Pesquisa?

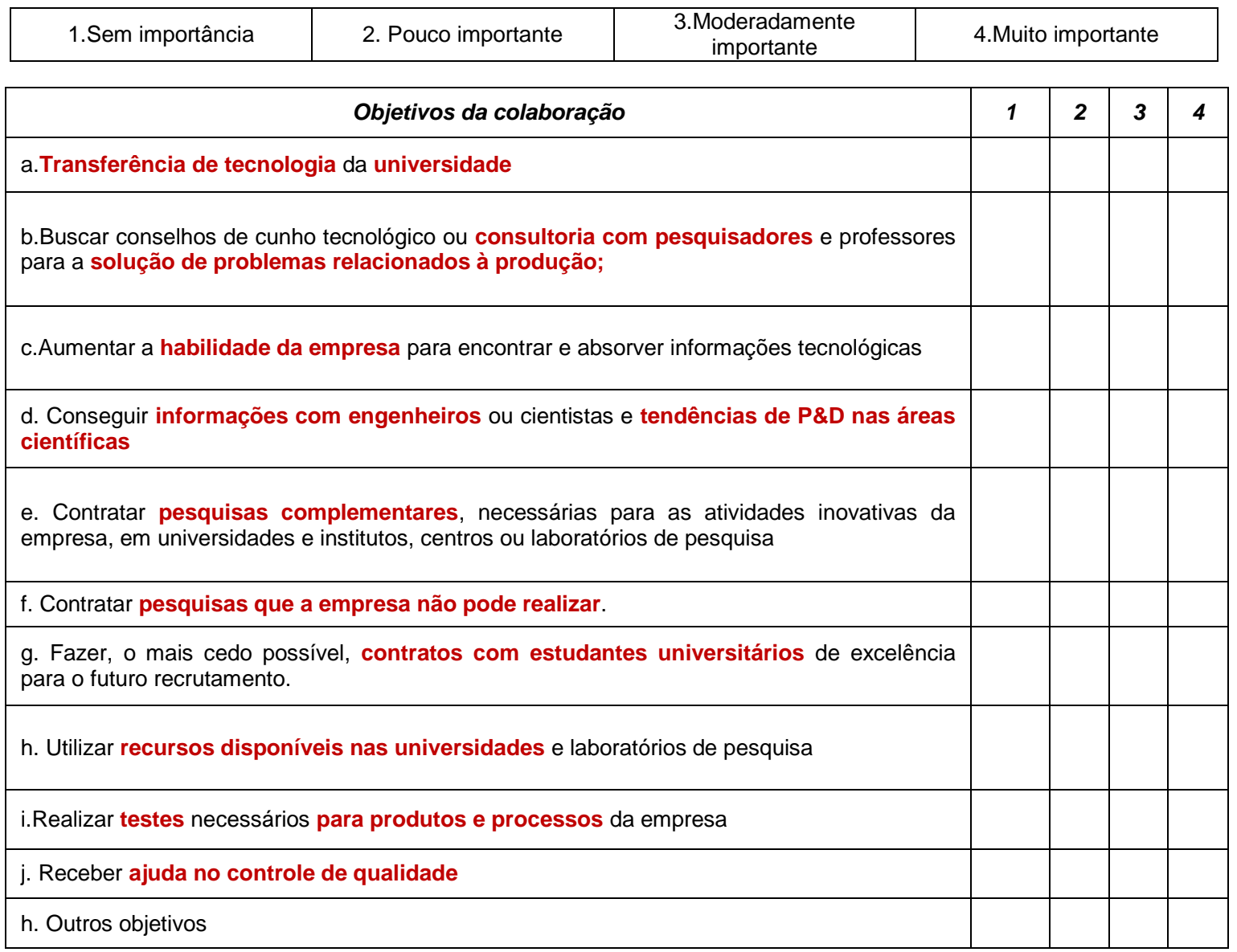


39. Quem apresentou iniciativa para estabelecer os relacionamentos entre a empresa e o grupo? (Pode-se marcar mais de uma opção).

\begin{tabular}{|l|l|}
\hline \multicolumn{2}{|c|}{ Alternativas } \\
\hline a. Empresa & \\
\hline b. O grupo de pesquisa & \\
\hline c. As iniciativas foram compartilhadas pelo grupo e pela empresa & \\
\hline d. Mecanismos institucionais da universidade/instituto de pesquisa para a transferência de tecnologia & \\
\hline e.Outro (Especifique) & \\
\hline
\end{tabular}

40. Em geral, a colaboração com universidades e institutos de pesquisa apresentou resultados em termos de atingir os objetivos esperados? Escolha uma alternativa.

Alternativas

a. Sim, até agora a colaboração tem sido bem-sucedida; (SIM)

b. Não, a colaboração não tem sido um sucesso; (NÃO)

c. A colaboração ainda está em andamento, mas acredito que os objetivos serão atingidos no tempo previsto. (SIM)

d. A colaboração ainda não se completou, mas acredito que os objetivos não serão atingidos (NÃO)

Se a resposta na questão 39 foi "A" ou "C" , continue a responder a partir da questão 41.

Se a resposta na questão 39 foi "B" ou "D", continue a responder a partir da questão 42.

41. Por que a colaboração com Universidade e Institutos de Pesquisa NÃO atingiu os objetivos?

\begin{tabular}{|c|c|c|c|}
\hline $\begin{array}{c}\text { 1.Sem } \\
\text { importância }\end{array}$ & $\begin{array}{c}\text { 2. Pouco } \\
\text { importante }\end{array}$ & $\begin{array}{c}\text { 3.Moderadamente } \\
\text { importante }\end{array}$ & $\begin{array}{c}\text { 4.Muito } \\
\text { importante }\end{array}$ \\
\hline
\end{tabular}

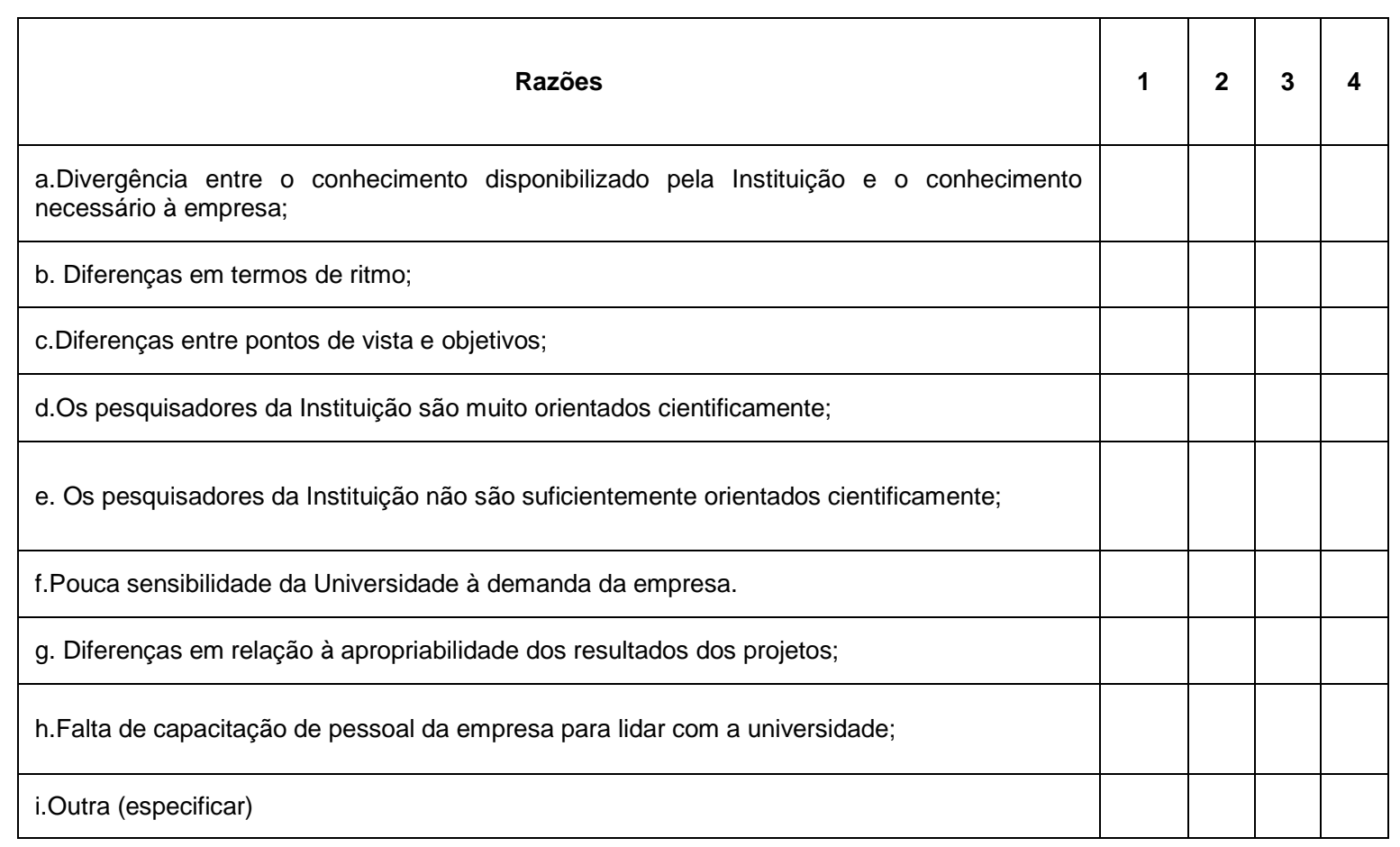

42. Quais os principais resultados da interação entre a empresa e universidade/institutos de pesquisa?

\begin{tabular}{|c|c|c|c|}
\hline $\begin{array}{c}\text { 1.Sem } \\
\text { Importância }\end{array}$ & $\begin{array}{c}\text { 2. Pouco } \\
\text { importante }\end{array}$ & $\begin{array}{c}\text { 3.Moderadamente } \\
\text { importante }\end{array}$ & $\begin{array}{c}\text { 4.Muito } \\
\text { importante }\end{array}$ \\
\hline
\end{tabular}


\begin{tabular}{|l|l|l|l|}
\hline & & & \\
\hline
\end{tabular}

Resultados da interação empresa (ou institutos) e universidade

a. Desenvolvimento conjunto (Projeto) da máquinas;

b. Melhoria técnica nas condições de uso das máquinas;

c. Teste de novas tecnologias, em experiência com a empresa;

d. Teste das tecnologias existentes em novos materiais, em experiência com a empresa

e. Consultoria por parte da empresa;

f. Consultoria por parte da instituição;

g. Outros

43. Há quanto tempo a empresa tem colaborado com universidade/institutos de pesquisa?

\begin{tabular}{|l|l|}
\hline \multicolumn{1}{|c|}{ Alternativas } & \\
\hline a.Há menos de um ano & \\
\hline b.Entre um e dois anos & \\
\hline c.Entre dois e cinco anos & \\
\hline d.Entre cinco e dez anos & \\
\hline e.Há mais de dez anos & \\
\hline
\end{tabular}

44. Em geral, como são financiados os projetos em colaboração com as universidades e institutos de pesquisa?

\begin{tabular}{|l|c|}
\hline \multicolumn{1}{|c|}{ Categorias de financiamento } & \% média \\
\hline a. Recursos próprios & \\
\hline b. Recursos públicos (FINAME, FUNEP, BNDES) & \\
\hline c. Recursos de terceiros (capital de risco, bancos privados, etc. & \\
\hline
\end{tabular}

45. Se você assinalou a letra "b", assinale qual o mecanismo foi utilizado nos últimos três anos.

\begin{tabular}{|l|l|}
\hline Incentivo fiscal à P\&D e inovação tecnológica & \\
\hline $\begin{array}{l}\text { Financiamento para a participação em projetos de P\&D e inovação tecnológica em parceria } \\
\text { com universidades e institutos, centros e laboratórios de pesquisa }\end{array}$ & \\
\hline Financiamento para projetos de P\&D e inovação tecnológica & \\
\hline Financiamento para compra de máquinas e equipamentos utilizados para inovar & \\
\hline Bolsas oferecidas por FAPs e RHAE/CNPQ para pesquisadores em empresas & \\
\hline Aporte de capital de risco & \\
\hline Outros (favor especificar) & \\
\hline
\end{tabular}

46. Especifique a linha de pesquisa e a respectiva área de conhecimento que as universidades de pesquisa do país necessitam avançar para apoiar as atividades inovativas de sua empresa.

\begin{tabular}{|l|l|}
\hline Áreas de conhecimento & Linhas de pesquisa (correspondente) \\
\hline & \\
\hline & \\
\hline & \\
\hline & \\
\hline & \\
\hline & \\
\hline
\end{tabular}


2. Questionário aplicado nos grupos de pesquisa com atuação no ramo de máquinasferramenta

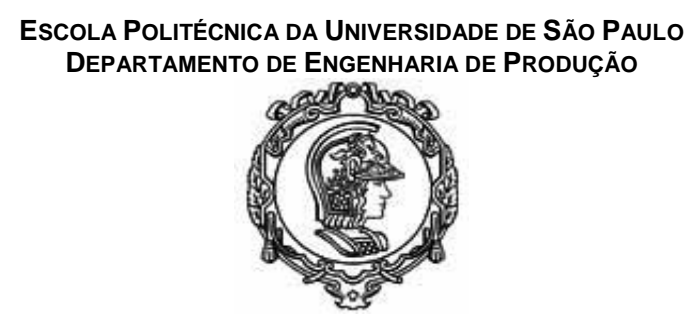

QUeStões APLICADAS NOS GRUPos de PESQUISA COM ATUAÇÃo NO SETOR DE MÁQUINAS E EQUIPAMENTOS

DATA DE REALIZAÇÃO DA ENTREVISTA:

TEMPO DE DURAÇÃO: horas e $\min (:$ às : )

Identificação do entrevistado e de sua trajetória no grupo

Nome:

Área de atuação:

Cargo:

Tempo de grupo:

Formação:

Dados Gerais do grupo

Nome:

Ano de fundação:

Atividades principais

1. Na opinião do GRUPO, quais fatores relacionados aos produtos/processos são mais importantes para a competitividade do setor de MFs no mercado interno? (1 a 4)

\begin{tabular}{|c|c|c|c|}
\hline 1.Sem importância & 2. Pouco importante & $\begin{array}{c}\text { 3.Moderadamente } \\
\text { importante }\end{array}$ & 4.Muito importante \\
\hline Fator de competitividade & $\begin{array}{l}\text { Nota } \\
(1-4)\end{array}$ & \multicolumn{2}{|c|}{ Justificativa } \\
\hline \multicolumn{4}{|l|}{ Custo } \\
\hline \multicolumn{4}{|l|}{ Projeto de produto } \\
\hline \multicolumn{4}{|l|}{ Qualidade } \\
\hline \multicolumn{4}{|l|}{ Flexibilidade } \\
\hline \multicolumn{4}{|l|}{ Produtividade } \\
\hline \multicolumn{4}{|l|}{ Assistência técnica } \\
\hline \begin{tabular}{|ll}
$\begin{array}{l}\text { Utilização para outros } \\
\text { materiais }\end{array}$ & \\
\end{tabular} & & & \\
\hline
\end{tabular}




\begin{tabular}{|l|l|l|}
\hline Concorrência externa & & \\
\hline $\begin{array}{l}\text { Condições econômicas } \\
\text { mercado interno }\end{array}$ & & \\
\hline Outro - qual & & \\
\hline & & \\
\hline
\end{tabular}

2. Na opinião do GRUPO, quais fatores relacionados aos produtos/processos são mais importantes para a competitividade do setor de MFs no mercado externo (inclusive América Latina)? (1 a 4)
1.Sem importância
2. Pouco importante
3.Moderadamente importante
4.Muito importante

\begin{tabular}{|l|l|l|}
\hline \multicolumn{1}{|c|}{ Fator de competitividade } & $\begin{array}{l}\text { Nota } \\
(\mathbf{1 - 4})\end{array}$ & \\
\hline Custo & & \\
\hline Projeto de produto & & \\
\hline Qualidade & & \\
\hline Flexibilidade & & \\
\hline Produtividade & & \\
\hline Assistência técnica & \\
\hline Utilização para novos materiais & & \\
\hline Concorrência externa & & \\
\hline $\begin{array}{l}\text { Condições econômicas } \\
\text { mercado interno }\end{array}$ & & \\
\hline Outro - qual? & & \\
\hline
\end{tabular}

3. Quais os principais concorrentes (empresas ou países) da empresa de MFs no mercado interno e externo

\begin{tabular}{|l|l|}
\hline \multicolumn{2}{|c|}{ Concorrentes da empresa de máquinas-ferramenta } \\
\hline Mercado interno & Mercado externo \\
\hline & \\
\hline & \\
\hline
\end{tabular}

4. Como a instituição classifica a relação com entre empresas de MFs e os setores usuários das máquinasferramenta?

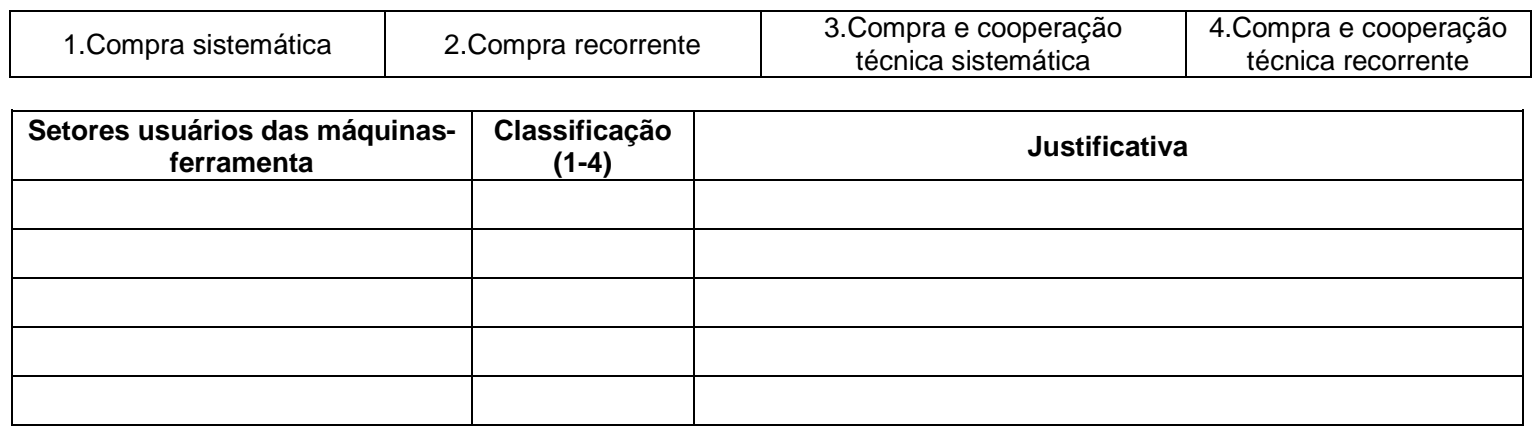

5. Como o GRUPO classifica a relação das empresas de MFs (BR) com fornecedores de insumos e equipamentos do mercado interno

\begin{tabular}{|l|c|c|c|}
\hline 1.Compra sistemática & 2.Compra recorrente & $\begin{array}{c}\text { 3.Compra e cooperação } \\
\text { técnica sistemática }\end{array}$ & $\begin{array}{c}\text { 4.Compra e cooperação } \\
\text { técnica recorrente }\end{array}$ \\
\begin{tabular}{|l|c|c|}
\hline \multicolumn{1}{|c|}{ Descrição } & $\begin{array}{c}\text { Classificação } \\
(1-4)\end{array}$ & Justificativa \\
\hline Fornecedor de insumo & & \\
\hline 1. & &
\end{tabular} \\
\hline 2. &
\end{tabular}




\begin{tabular}{|l|l|l|}
\hline 3. & & \\
\hline 4. & \multicolumn{2}{|l|}{} \\
\hline \multicolumn{2}{|l|}{ Fornecedor de equipamentos } & \\
\hline 1. & & \\
\hline 2. & & \\
\hline 3. & & \\
\hline 4. & & \\
\hline Fornecedor de ferramentas & & \\
\hline 1. & & \\
\hline 2 & & \\
\hline 3 & & \\
\hline 4 & & \\
\hline
\end{tabular}

6. Na opinião do GRUPO, quais foram as inovações mais importantes dos últimos anos no setor MFs (ou indústria bens de capital)? Quais foram seus impactos?

7. Em relação às inovações recentes do setor, as empresas brasileiras incorporaram tais inovações? Por quê?

8. Como a instituição caracteriza a natureza do desenvolvimento tecnológico interno (explique):

c) Produto - radical ou incremental ou ambos:

d) Processo - radical ou incremental ou ambos:

9. Na opinião do GRUPO, qual a importância das áreas de conhecimento listadas a seguir para o desenvolvimento e melhorias das máquinas (dê um exemplo de produtos em cada área)?

\begin{tabular}{|c|c|c|c|}
\hline 1.Sem importância & 2. Pouco importante & $\begin{array}{c}\text { 3.Moderadamente } \\
\text { importante }\end{array}$ & 4.Muito importante \\
\hline
\end{tabular}

\begin{tabular}{|l|c|c|}
\hline $\begin{array}{c}\text { Áreas de } \\
\text { conhecimento }\end{array}$ & $\begin{array}{c}\text { Notas } \\
(\mathbf{1}-4)\end{array}$ & $\begin{array}{c}\text { Contribuições da área para o desenvolvimento (melhorias) das MFs } \\
\text { da empresa }\end{array}$ \\
\hline Produção: & & \\
\hline & & \\
\hline Mecânica: & & \\
\hline Eletrônica: & & \\
\hline & & \\
\hline Mecatrônica: & & \\
\hline Outras (quais) & & \\
\hline & & \\
\hline
\end{tabular}

10. Na opinião do GRUPO, quais os fatores determinantes (motivador) para as empresas brasileiras incorporarem os conhecimentos dessas áreas à sua linha de produtos? (1-4)
1.Sem importância
2. Pouco importante
3.Moderadamente importante
4.Muito importante 


\begin{tabular}{|l|l|l|}
\hline \multicolumn{1}{|c|}{ Determinantes } & $\begin{array}{c}\text { Notas } \\
(\mathbf{1 - 4})\end{array}$ & \\
\hline $\begin{array}{l}\text { Alterações nas características } \\
\text { dos materiais (mercado) }\end{array}$ & & \\
\hline $\begin{array}{l}\text { Alterações nas características } \\
\text { dos materiais (do usuário) }\end{array}$ & & \\
\hline $\begin{array}{l}\text { Atualização das características } \\
\text { técnicas das máquinas }\end{array}$ & & \\
\hline $\begin{array}{l}\text { Resolução de problemas } \\
\text { técnicos }\end{array}$ & & \\
\hline Lucro mo mercado & & \\
\hline $\begin{array}{l}\text { Desempenho no } \\
\text { interno }\end{array}$ & & \\
\hline Inserção no mercado externo & & \\
\hline $\begin{array}{l}\text { Desempenho no mercado } \\
\text { externo }\end{array}$ & & \\
\hline
\end{tabular}

11. Na opinião do GRUPO, como os conhecimentos dessas áreas têm influenciado o desenvolvimento das máquinas da empresa?

12. Eventuais mudanças nessas áreas de conhecimento representam uma oportunidade ou ameaça para 0 desenvolvimento das máquinas-ferramenta da empresa? E do setor nacional ? Por quê? (cite ao menos um exemplo)

13. Quais as condições enfrentadas pela empresa para o acesso às informações de diferentes áreas de conhecimento?

14. A instituição considera que o setor de MFs apresenta alta ou baixa oportunidade para o desenvolvimento de MFs? Por quê?

15. Sobre os instrumentos de proteção das informações, quais os mais usados pelo setor de MFs? Eles são eficazes? Há dificuldades (quais)?

\begin{tabular}{|c|c|c|}
\hline \multirow{2}{*}{$\begin{array}{c}\text { Mecanismos de proteção das } \\
\text { informações }\end{array}$} & \multicolumn{2}{|c|}{ Produto } \\
\hline & $\begin{array}{l}\text { Eficácia } \\
\text { (sim/não) }\end{array}$ & $\begin{array}{c}\text { Dificuldades } \\
\text { (dificuldade alta, média ou baixa) }\end{array}$ \\
\hline \multicolumn{3}{|l|}{ Patente } \\
\hline \multicolumn{3}{|l|}{ Defasagem temporal } \\
\hline \multicolumn{3}{|l|}{ Complexidade } \\
\hline \multicolumn{3}{|l|}{ Aprendizado } \\
\hline Lead time & & \\
\hline
\end{tabular}




\begin{tabular}{|l|l|l|}
\hline Curva de aprendizado & & \\
\hline Custo e tempo requerido & & \\
\hline Canais de comercialização & & \\
\hline Outros mecanismos & & \\
\hline & & \\
\hline
\end{tabular}

\begin{tabular}{|c|c|c|}
\hline \multirow{2}{*}{$\begin{array}{c}\text { Mecanismos de proteção das } \\
\text { informações }\end{array}$} & \multicolumn{2}{|c|}{ Processo } \\
\hline & $\begin{array}{l}\text { Eficácia } \\
\text { (sim/não) }\end{array}$ & $\begin{array}{c}\text { Dificuldades } \\
\text { (dificuldade alta, media ou baixa) }\end{array}$ \\
\hline \multicolumn{3}{|l|}{ Patente } \\
\hline \multicolumn{3}{|l|}{ Defasagem temporal } \\
\hline \multicolumn{3}{|l|}{ Complexidade } \\
\hline \multicolumn{3}{|l|}{ Aprendizado } \\
\hline \multicolumn{3}{|l|}{ Lead time } \\
\hline \multicolumn{3}{|l|}{ Curva de aprendizado } \\
\hline \multicolumn{3}{|l|}{ Custo e tempo requerido } \\
\hline \multicolumn{3}{|l|}{ Canais de comercialização } \\
\hline Outros mecanismos & & \\
\hline & & \\
\hline
\end{tabular}

\section{Quais as razões da interação empresa-GRUPO?}

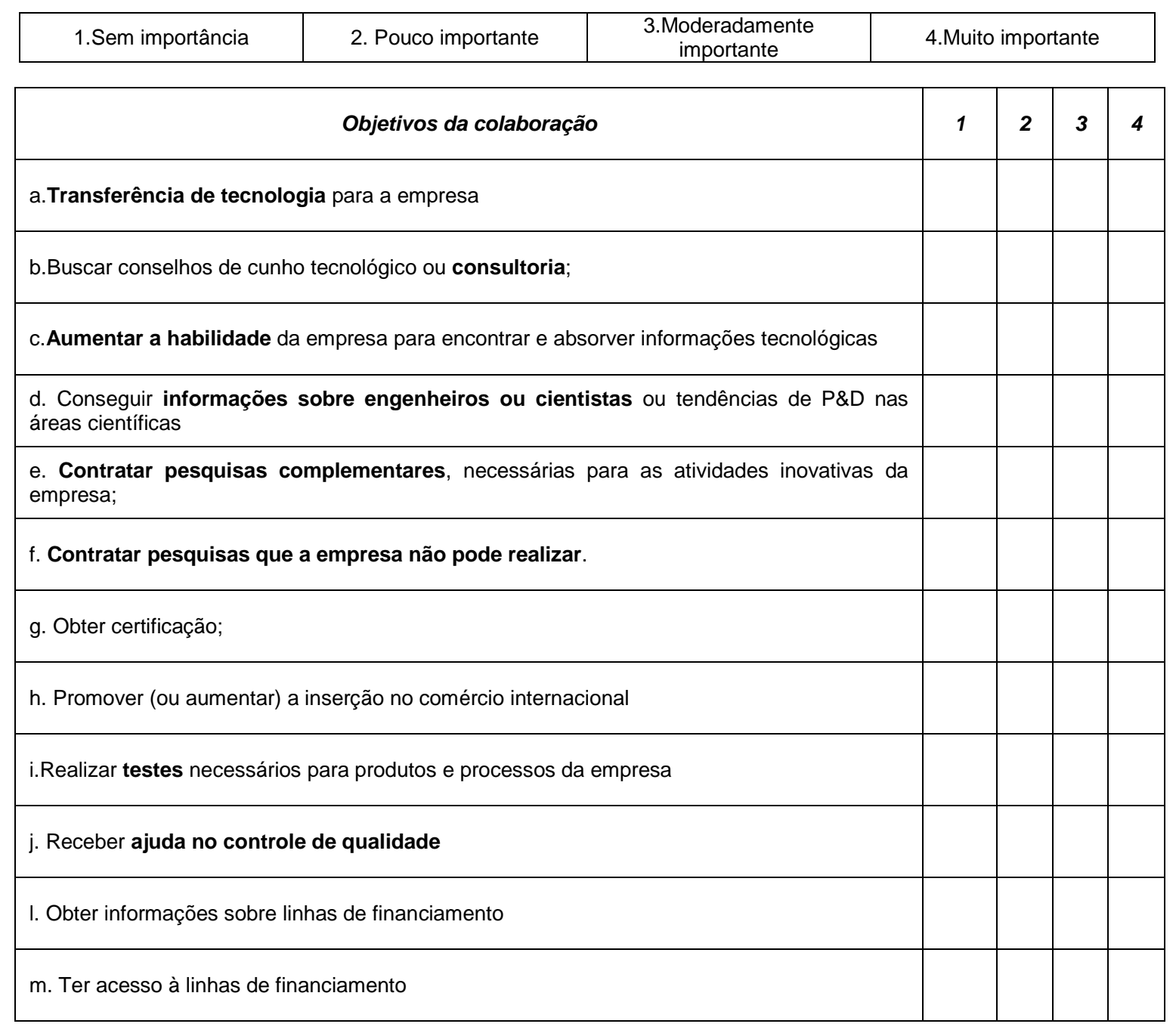


n. Outras

17. Quem apresentou iniciativa para estabelecer os relacionamentos entre a empresa e o GRUPO? (Pode-se marcar mais de uma opção).

\begin{tabular}{|l|l|}
\hline \multicolumn{2}{|c|}{ Alternativas } \\
\hline a. Empresa & \\
\hline b. GRUPO & \\
\hline c. As iniciativas foram compartilhadas pelo GRUPO e a empresa & \\
\hline d. Mecanismos institucionais da universidade/instituto de pesquisa para a transferência de tecnologia & \\
\hline e.Outro (Especifique) & \\
\hline
\end{tabular}

18. Há colaboração dos atores citados a seguir para o desenvolvimento de produtos e melhorias das máquinas? (Dê exemplos)

\begin{tabular}{|c|c|c|}
\hline \multirow{2}{*}{ INSTITUIÇÕES } & \multicolumn{2}{|c|}{ PRODUTOS } \\
\hline & $\begin{array}{l}\text { Nome da } \\
\text { instituição }\end{array}$ & Objetivo da interação \\
\hline \multicolumn{3}{|l|}{ Fomento (BNDES, Caixa Econômica) } \\
\hline \multicolumn{3}{|l|}{ Ensino e pesquisa - pública e privada } \\
\hline \multicolumn{3}{|l|}{ Instituto de normatização e testes } \\
\hline \multicolumn{3}{|l|}{ Formação de recursos humanos } \\
\hline \multicolumn{3}{|l|}{$\begin{array}{l}\text { Fornecedores de insumos/ } \\
\text { Componentes }\end{array}$} \\
\hline \multicolumn{3}{|l|}{$\begin{array}{l}\begin{array}{l}\text { Fornecedores de componentes } \\
\text { eletrônica, etc. }\end{array} \\
\end{array}$} \\
\hline \multicolumn{3}{|l|}{ Consumidores/usuários } \\
\hline Outros & & \\
\hline & & \\
\hline
\end{tabular}

19. Há colaboração dos atores citados a seguir para o desenvolvimento e melhoria dos processos (Dê exemplo).

\begin{tabular}{|l|l|l|}
\hline \multirow{2}{*}{\multicolumn{2}{|c|}{ INSTITUIÇÕES }} & \multicolumn{2}{c|}{ PROCESSOS /TECNOLOGIAS } \\
\cline { 2 - 3 } & $\begin{array}{c}\text { Nome da } \\
\text { instituição }\end{array}$ & Objetivo da interação \\
\hline Fomento (BNDES, Caixa Econômica) & & \\
\hline & & \\
\hline
\end{tabular}




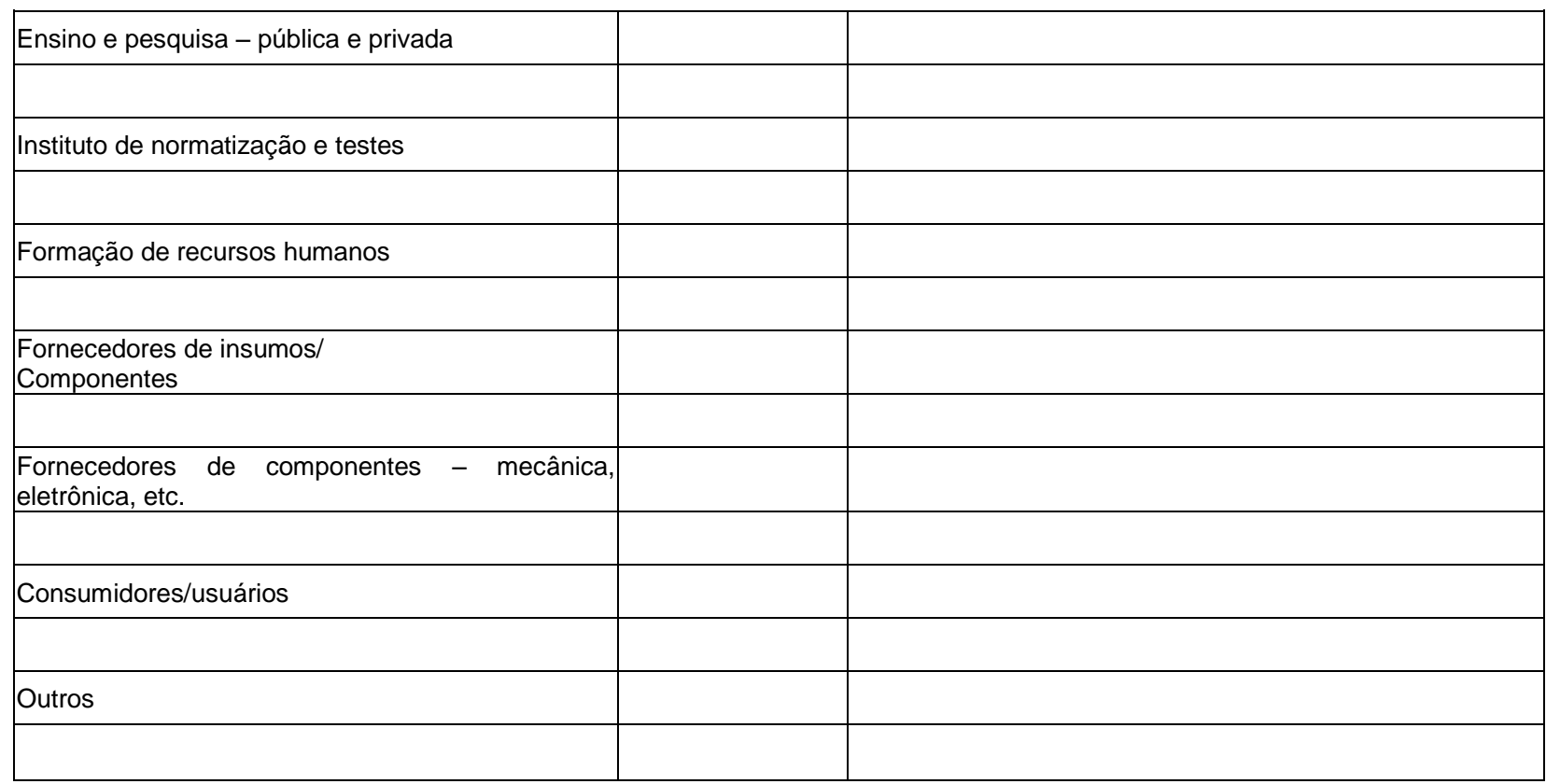

20. Qual(is) o(s) instrumento(s) público de incentivo às atividades de P\&D utilizados nos últimos três anos por empresas de MFs?

21. Em geral, a colaboração com o instituto apresentou resultados em termos de atingir os objetivos esperados? Escolha uma alternativa.

\section{Alternativas}

a. Sim, até agora a colaboração tem sido bem-sucedida;

b. Não, a colaboração não tem sido um sucesso;

c. A colaboração ainda está em andamento, mas acredito que os objetivos serão atingidos no tempo previsto.

d. A colaboração ainda não se completou, mas acredito que os objetivos não serão atingidos

Se a resposta na questão 19 foi "A" ou "C" , continue a responder a partir da questão 22.

Se a resposta na questão 19 foi "B" ou "D", continue a responder a partir da questão 23.

22. Quais os principais resultados da interação entre o GRUPO e as empresas de máquinas?

\begin{tabular}{|c|c|c|c|}
\hline $\begin{array}{c}\text { 1.Sem } \\
\text { importância }\end{array}$ & $\begin{array}{c}\text { 2. Pouco } \\
\text { importante }\end{array}$ & $\begin{array}{c}\text { 3.Moderadamente } \\
\text { importante }\end{array}$ & $\begin{array}{c}\text { 4.Muito } \\
\text { importante }\end{array}$ \\
\hline
\end{tabular}

\begin{tabular}{|c|c|c|c|c|}
\hline Resultados do relacionamento GRUPO com empresas & 1 & 2 & 3 & 4 \\
\hline Novos projetos de pesquisa & & & & \\
\hline Novos produtos e artefatos & & & & \\
\hline Novos processos industriais & & & & \\
\hline Melhoria de produtos & & & & \\
\hline Melhoria de processos & & & & \\
\hline
\end{tabular}




\begin{tabular}{|l|l|l|l|}
\hline Formação de recursos humanos & & & \\
\hline Atualização de recursos humanos & & & \\
\hline Desempenho das vendas do setor no comércio internacional & & & \\
\hline Certificações (quais) & & & \\
\hline Desempenho das vendas do setor no mercado interno & & & \\
\hline Outros & & & \\
\hline & & & \\
\hline
\end{tabular}

23. Por que a colaboração entre as empresas e Institutos de Pesquisa não atingiu os objetivos?

\begin{tabular}{|c|c|c|c|}
\hline $\begin{array}{c}\text { 1.Sem } \\
\text { importância }\end{array}$ & $\begin{array}{c}\text { 2. Pouco } \\
\text { importante }\end{array}$ & $\begin{array}{c}\text { 3.Moderadamente } \\
\text { importante }\end{array}$ & $\begin{array}{c}\text { 4.Muito } \\
\text { importante }\end{array}$ \\
\hline
\end{tabular}

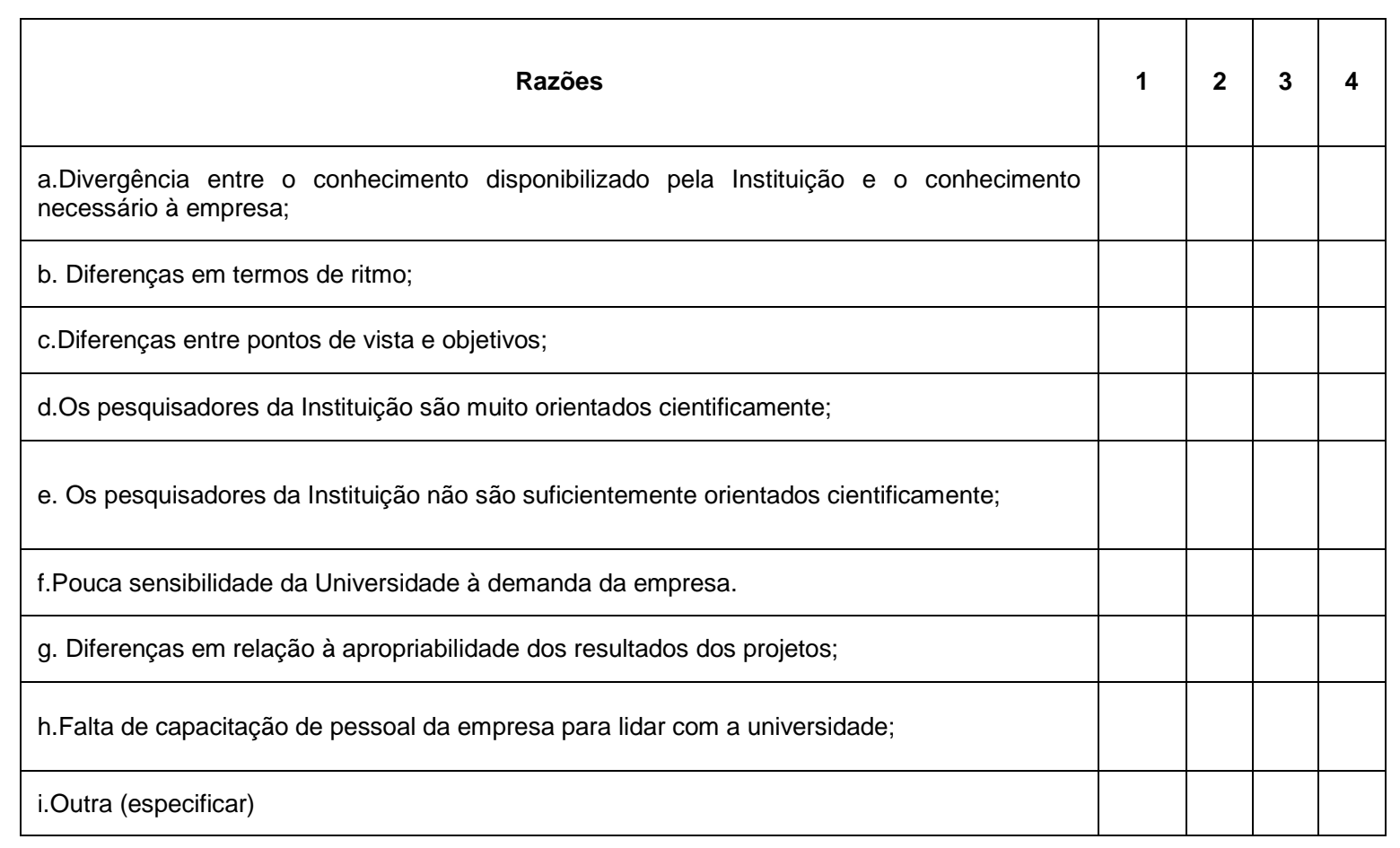

24. Em geral, como são financiados os projetos em colaboração entre o GRUPO e as empresas de máquinas?

\begin{tabular}{|l|l|}
\hline \multicolumn{1}{|c|}{ Origem do capital utilizado em projetos em colaboração } & \% média \\
\hline a. Recursos próprios (empresa) & \\
\hline b.Recursos públicos (FINEP, CNPq, FAPs, BNDES, etc). & \\
\hline c. Recursos de terceiros (capital de risco, bancos privados, etc.) & \\
\hline
\end{tabular}

25. Se você assinalou valor maior que zero na letra "b", assinale qual o mecanismo foi utilizado nos últimos três anos. 


\begin{tabular}{|l|l|}
\hline Incentivo fiscal à P\&D e inovação tecnológica & \\
\hline $\begin{array}{l}\text { Financiamento para a participação em projetos de P\&D e inovação tecnológica em parceria com } \\
\text { universidades e institutos, centros e laboratórios de pesquisas }\end{array}$ & \\
\hline Financiamento para projetos de P\&D e inovação tecnológica & \\
\hline Financiamento para a compra de máquinas e equipamentos utilizados para inovar & \\
\hline Bolsas oferecidas pelas FAPs e RHAE/CNPQ para pesquisadores em empresas & \\
\hline Aporte de capital de risco & \\
\hline Outros (favor especificar) & \\
\hline
\end{tabular}

26. Quais as principais dificuldades do relacionamento entre o GRUPO e as empresas de máquinas. Classifique de acordo com o grau de importância para a instituição.

\begin{tabular}{|c|c|c|c|}
\hline $\begin{array}{c}\text { 1.Sem } \\
\text { importância }\end{array}$ & $\begin{array}{c}\text { 2. Pouco } \\
\text { importante }\end{array}$ & $\begin{array}{c}\text { 3.Moderadamente } \\
\text { importante }\end{array}$ & $\begin{array}{c}\text { 4.Muito } \\
\text { importante }\end{array}$ \\
\hline
\end{tabular}

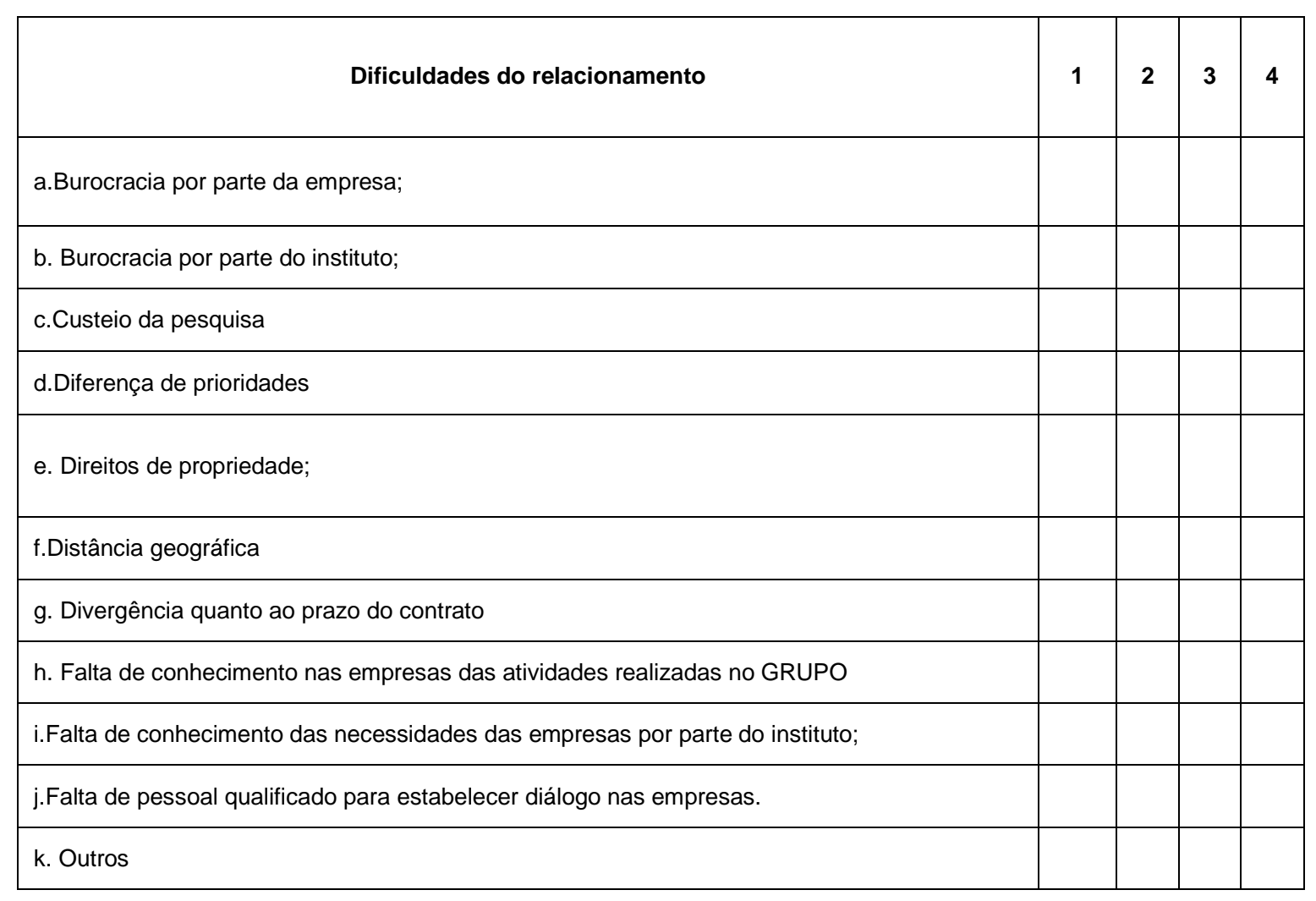


ANEXO C - INFORMAÇÕES SOBRE AS EMPRESAS E OS GRUPOS DE PESQUISA

\section{Informações sobre as empresas de máquinas-ferramenta e as linhas de produtos fabricados}

Quadro 8 - Empresas de máquinas-ferramenta, linhas de produtos e tipos de máquinas

\begin{tabular}{|c|c|c|c|c|c|c|c|}
\hline \multirow{2}{*}{ Linhas de produtos } & \multirow{2}{*}{ Tipos de máquinas } & \multicolumn{6}{|c|}{ Empresas de máquinas-ferramenta selecionadas } \\
\hline & & B. Grob & $\begin{array}{l}\text { D. R. } \\
\text { Promaq }\end{array}$ & Ergomat & Ferdimat & Index & Romi \\
\hline \multicolumn{8}{|l|}{ Máquinas } \\
\hline Células robotizadas & $\begin{array}{l}\text { Para montagem e teste de } \\
\text { cabecotes de motor; }\end{array}$ & & $x$ & & & & \\
\hline $\begin{array}{l}\text { Células robotizadas para } \\
\text { roscar }\end{array}$ & & & $\mathrm{X}$ & & & & \\
\hline \multirow{4}{*}{ Centros de usinagem } & & $\mathrm{x}$ & & & & & $x$ \\
\hline & Verticais CNC & & $x$ & & & & \\
\hline & Tipo Gantry & & & & $x$ & & \\
\hline & Pórtico & & & & $X(4)$ & & \\
\hline $\begin{array}{l}\text { Centros de usinagem e } \\
\text { fresadoras }\end{array}$ & & & & $\mathrm{X}(3)$ & & & \\
\hline \multirow{5}{*}{ Centros de torneamento } & & & & & & & $\mathrm{x}$ \\
\hline & Carro múltiplo & & & $x$ & & & \\
\hline & e Retífica & & & & & $X(1)$ & \\
\hline & e Fresamento & & & & & $X(1)$ & \\
\hline & Vertical & & & & & $X(1)$ & \\
\hline $\begin{array}{l}\text { Equipamentos para montagem } \\
\text { e teste }\end{array}$ & Torqueadeira CNC 4 eixos & & $\mathrm{X}$ & & & & \\
\hline \multirow{4}{*}{ Fresadora } & de Cremalheira & & & & $x$ & & \\
\hline & Ferramenteira & & & & $\mathrm{X}(4)$ & & \\
\hline & CNC & & & & $X(4)$ & & \\
\hline & CNC de banco fixo & & & & $X(4)$ & & \\
\hline $\begin{array}{l}\text { Linhas de montagem e teste } \\
\text { de Freio a Disco; }\end{array}$ & & & $x$ & & & & \\
\hline \multirow{2}{*}{ Madrilhadoras } & Mecânica & & & & $X(4)$ & & \\
\hline & CNC & & & & $X(4)$ & & $x$ \\
\hline Máquinas-ferramenta especiais & & $x$ & & & & & \\
\hline Máquinas de montagem & & $x$ & & & & & \\
\hline \multirow{4}{*}{ Retificadora } & Tangenciais & & & & $x$ & & \\
\hline & Cilíndricas & & & & $x$ & & \\
\hline & De internos & & & & $x$ & & \\
\hline & Cilíndricas CNC & & & & $x$ & & \\
\hline
\end{tabular}




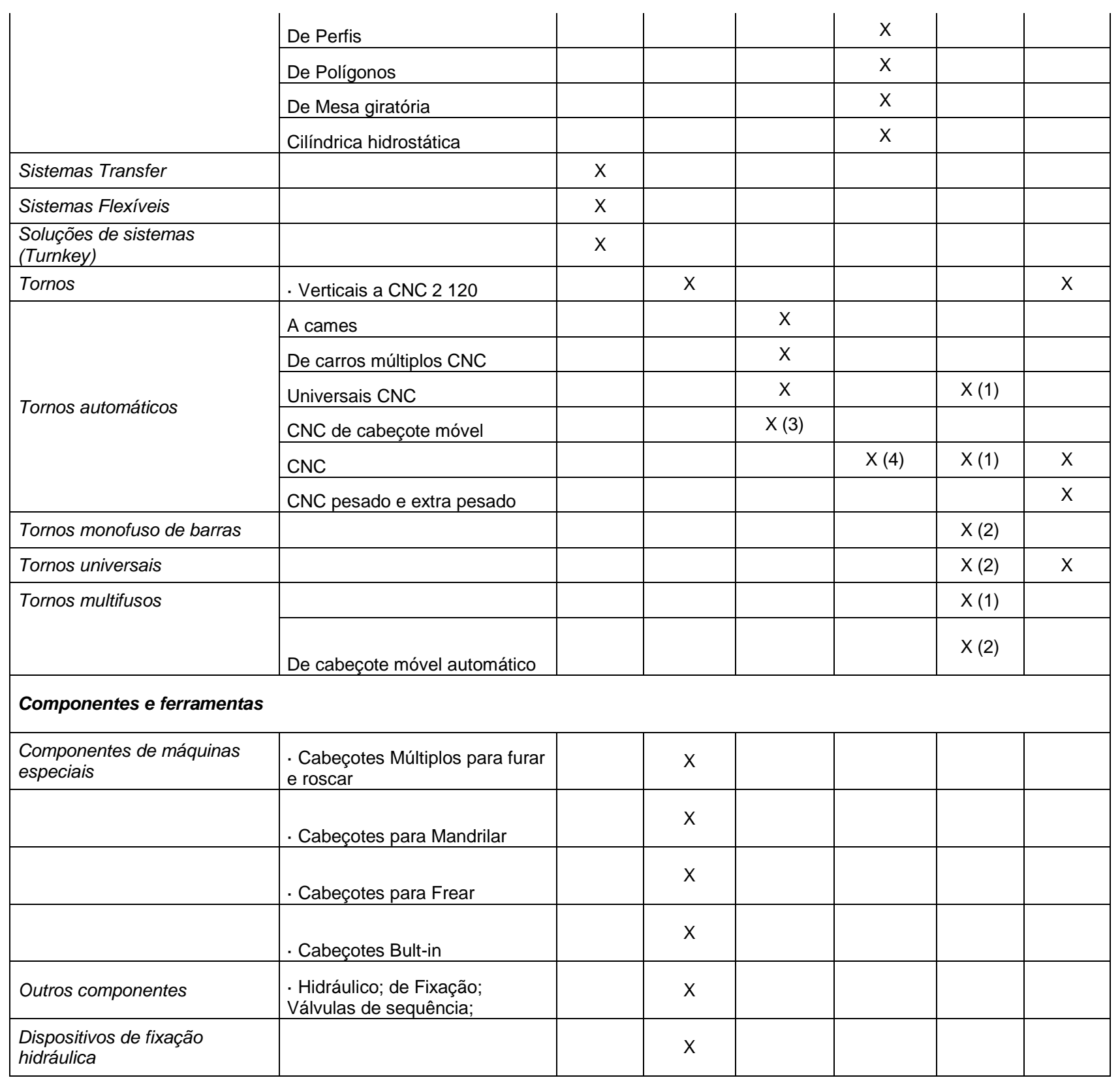

Fonte: elaboração própria, com base nos dados disponíveis no sítio das empresas.

(1) Produtos Index; (2) Produtos Traub; (3) Máquinas não fabricadas no Brasil. A Ergomat tornou-se represente das empresas Hardinge e Star. (4) Máquinas importadas pela Ferdimat. 


\section{Notas técnicas sobre as empresas de máquinas-ferramenta visitadas}

As informações apresentadas a seguir foram obtidas a partir de pesquisa realizada no sítio eletrônico das empresas.

\section{B. Grob}

A B. Grob é uma empresa de grande porte que foi fundada em 1926 na cidade Munique, na Alemanha. Somente em 1968, a empresa transferiu sua unidade produtiva para a cidade de Mindelheim, na Alemanha. E em 1976 essa unidade se tornou a fábrica matriz do grupo Grob.

A empresa tem origem e administração familiar e se encontra hoje na sua terceira geração. Desde 1952, é dirigida pelo Dr. Burkhart Grob.

O grupo começou suas atividades com a produção de máquinas fresadoras-rosca em 1933. No período entre a década de 1930 e os anos 1970, a empresa expandiu a produção com as linhas de máquinas laminadoras e máquinas-ferramenta especiais. Ainda nos anos 70 , a empresa produziu a primeira linha transfer.

Nos anos 80, a Grob começou a fabricar máquinas automatizadas: linha de montagem automatizada (1982) e robô (1984).

No período entre os anos 1980 e 1990, o grupo apresentou expansão de suas atividades de vendas, representação e serviços, com a inauguração das filiais em Buffon (EUA) e da Grã Bretanha. Além disso, no final da década de 90 a Grob investiu na ampliação da área fisica da unidade fabril dos EUA e da matriz.

Desde 2000, a empresa tem mantido sua estratégia de expansão das unidades de representação e assistência com a inauguração de filiais de venda no México e de filiais na República Popular da China (2003), em Shangai e na Coréia do Sul (2005).

A Grob opera mundialmente através de sua matriz em Mindelheim (Alemanha) e das filiais sediadas em São Paulo (Brasil) e Bluffton/Ohio (USA) e Dalian (China).

As unidades de assistência técnica e vendas estão localizadas em Shanghai (República Popular da China), em Seul (Coréia do Sul ), em Wellesbourne (Grã-Bretânia), em Querétaro (México), Hyderabad (Índia), Moscou (Rússia). Além disso, a empresa tem representações localizadas na França, Índia, Itália, Suécia, Espanha, República Tcheca, Eslováquia e Turquia.

O grupo Grob empresa 4.000 pessoas e apresenta faturamento anual de mais de 700 milhões de Euros.

A unidade produtiva da B. Grob do Brasil foi fundada em 1956, na cidade de São Bernardo do Campo, região do grande ABC em São Paulo. 
A fundação da filial brasileira foi influenciada pelo interesse em atender à demanda da indústria automobilística por máquinas-ferramenta na década de 50 . Entretanto, a instabilidade no desenvolvimento da indústria automobilística nacional nas décadas seguintes resultou em orientação produtiva e tecnológica da filial brasileira diferente da verificada na unidade matriz.

Em primeiro lugar, a B. Grob do Brasil começou a desenvolver competências visando a produção de máquinas especiais para outros ramos industriais, como forma de reduzir a dependência em relação a demanda da indústria automobilística nacional.

Nos últimos anos, os principais usuários das máquinas fabricadas pela filial brasileira são as empresas da indústria automobilística, mas a B. Grob do Brasil têm atuação no mercado interno e externo.

Em segundo lugar, a B. Grob do Brasil também apresentou dificuldades para manter o nível de desenvolvimento de tecnologias similar ao observado na matriz. Diante dessa condição, a filial passou a desempenhar papel distinto como 'global player' na produção mundial de máquinas do grupo Grob.

A filial brasileira participa de projetos de grande porte em parceria com a matriz e a filial dos EUA e se transformou em plataforma de produção de alguns modelos de máquinas exportadas pela matriz.

A B. Grob do Brasil emprega 700 pessoas e produz linhas de máquinas-ferramenta que abrange centros de usinagem; sistemas transfer; sistemas Flexíveis; soluções turnkey; máquinas especiais e equipamentos de montagem.

Fonte: Sítio do Grupo Grob e da filial B. Grob do Brasil. Disponível em: <http://www.grobgroup.com/en/> e $<$ http://www.grobgroup.com/pt/>. Acesso em 11.mar.2012.

\section{R. Promaq}

A D. R. Promaq é uma empresa de pequeno porte de capital nacional que foi fundada em 1986. Em 1999, a unidade produtiva da empresa foi instalada na cidade de São Bernardo do Campo, numa área de $2.500 \mathrm{~m}^{2}$ de área disponível.

A empresa desenvolve e produz máquinas especiais, tornos verticais CNC, equipamentos de teste, linhas de montagem e células robotizadas. Além disso, a D.R. Promaq produz dispositivos de fixação para usinagem, equipamentos especiais para indústria e componentes para fixação hidráulica.

As linhas de máquinas da D. R. Promaq são fabricadas sob encomenda e podem ser classificadas em cinco grupos: Máquinas de montagem e usinagem; Dispositivos; Componentes de Máquinas Especiais; e Componentes.

As principais linhas de máquinas de montagem são: Linhas de montagem e teste de Freio a Disco; Equipamentos para montagem e teste: torqueadeira CNC 4 eixos e Células 
robotizadas para montagem e teste de cabeçotes de motor. Ainda nesse grupo, destaca-se a fabricação de máquinas de usinagem: Tornos verticais a CNC 2 120; Centros de usinagem verticais CNC; Máquinas para usinagem de modelos CNC; e Células robotizadas para roscar. Os principais setores usuários das máquinas são a indústria automobilística.

Os componentes e dispositivos, por sua vez, são fabricados em pequenos lotes. Essas linhas de produtos incluem cabeçotes múltiplos para furar e roscar; cabeçotes de mandrilar; cabeçotes de fresar; e cabeçotes bult-in; componentes de fixação; válvulas de sequência; e componentes hidráulicos; e dispositivos de fixação hidráulica que são destinados a diferentes setores industriais.

A estrutura da empresa é dividida em quatro áreas: Vendas e Engenharia de aplicação; Engenharia de Projeto (2D e 3D); Administração \& Coordenação; Manufatura.

A empresa conta com aproximadamente 70 colaboradores diretos e representantes comerciais em diversas cidades do Brasil.

Fonte: Sítio da empresa D. R. Promaq. Disponível em: www.drpromaq.com.br. Acesso em: 20.mai.2012.

\subsection{Ergomat}

A Ergomat Indústria e Comércio Ltda é uma empresa nacional de médio porte que foi fundada em 1962. A unidade produtiva da empresa está sediada na cidade de São Paulo/SP.

A empresa produz uma ampla linha máquinas de tornear e fresar, o que abrange tornos automáticos a cames; tornos automáticos de carros múltiplos CNC; centro de torneamento de carros múltiplos e tornos automáticos universais CNC. Além disso, a empresa é representante das linhas de tornos automáticos CNC de cabeçote móvel, fabricados pela empresa Star; e revende centros de centros de usinagem e fresadoras produzidos pela empresa Hardinge/Bridgeport.

A Ergomat disponibiliza serviços de assistência técnica; venda de peças de reposição; serviços de reformas e modernização de máquinas. Além disso, a empresa apresenta um centro de treinamento técnico, no qual oferece cursos para usuários das máquinas Ergomat e fornece manuais completos das máquinas e comandos.

Boa parte dos clientes da empresa são empresas de pequeno porte dos setores automobilístico, autopeças, tornearias automáticas, hidráulica e pneumática, componentes médicos e odontológicos, telecomunicações, eletroeletrônicos e eletrodomésticos.

De acordo com o sítio da empresa, grande parte da produção dos tornos Ergomat é exportada para países como o Japão, a Alemanha, os Estados Unidos e mais 30 outros países nos cinco continentes.

Nos anos de 2007 e 2008, a Ergomat apresentou queda de seu desempenho industrial com a redução do número de pedidos das máquinas. De acordo com notícia publicada no 
jornal O Estado de São Paulo, em 2009 a empresa ficou quatro meses sem receber pedidos, inclusive externos. Nesse período, a empresa reduziu seu quadro de funcionários para 225 trabalhadores. Outro fator que dificultou o desempenho da empresa foi a valorização do real (Cleide Silva, 19/02/10).

Fonte: Sítio da empresa Ergomat. Disponível em: http://www.ergomat.com.br>. Acesso em: 20.mai.2012.

\section{Ferdimat}

A Ferdimat é uma empresa de pequeno porte que foi fundada em 1970 na cidade São José dos Campos, em São Paulo.

A empresa iniciou suas atividades com ferramentaria e usinagem. Em 1974, a empresa fabricou duas retificadoras apenas para atender à demanda de peças de alguns clientes.

Com a experiência adquirida em 1974, e visando a fabricação de um produto próprio, a Ferdimat começou o projeto de uma retificadora cilíndrica. Em 1976, a empresa começou a produzir retificadoras cilíndricas em paralelo com a atividade de ferramentaria.

A partir de 1978, a Ferdimat passou a fabricar exclusivamente retificadoras.

Em 1989, a Ferdimat construiu o primeiro protótipo do modelo de retificadora cilíndrica com CNC. Em 1996 a empresa iniciou a fabricação de retificadoras cilíndricas angulares e universais CNC e no ano seguinte, ela lançou a linha de Centros de Usinagem $\mathrm{CNC}$

A empresa começou a exportar os modelos de retificadoras (cilíndricas, planas tangenciais) para Europa, América do Norte e América do Sul em 1987.

No início da década de 1990, a Ferdimat investiu na aquisição de equipamentos e na ampliação da área construída para $7.000 \mathrm{~m}^{2}$ em terreno de $15.000 \mathrm{~m}^{2}$, visando o atendimento da demanda por máquinas no mercado interno e externo.

No ano de 2003, a Ferdimat iniciou a produção de retificadoras tangenciais planas de grandes dimensões, convencionais e CNC. Em 2009, a empresa começou a fabricar retificadora de perfis CNC e em 2010 e lançou a linha de centros de usinagem tipo Gantry.

Nas últimas duas décadas, a empresa Ferdimat tem enfrentado dificuldades para concorrer com empresas provenientes de outros países no mercado interno e externo. Uma das estratégias adotadas foi a criação, em 2006, de uma nova divisão da empresa, a Alfamat, que é responsável pela comercialização de máquinas importadas.

A Ferdimat produz máquinas retificadoras (tangenciais, cilíndricas, retificadoras de internos, cilíndricas CNC, retificadoras de perfis); centros de usingem tipo Gantry; máquinas especiais (fresadora de cremalheira, retificadora de polígonos, retificadora de mesa giratória e retificadora cilíndrica hidrostática) e máquinas construídas para escolas técnicas. 
Além desses modelos de máquinas, a empresa é importadora das seguintes linhas de máquinas: fresadoras (ferramenteira, fresadora CNC e fresadora CNC de banco fixo); centros de usinagem pórtico; madrilhadoras mecânicas; madrilhadoras CNC e tornos CNC.

A empresa disponibiliza serviços de pós-venda e assistência técnica para os produtos de fabricação própria e os produtos importados.

Em 2005, a empresa realizou investimentos para ampliar a área construída em 1.000 $\mathrm{m}^{2}$ com o objetivo de se adequar à nova unidade, e remodelou os escritórios e construiu um showroom para as máquinas. Além disso, a Ferdimat apresentou redução do número de sócios para dois.

Fonte: Sítio da empresa Ferdimat. Disponível em: http://www.ferdimat.com.br. Acesso em 25.mai.2012.

\section{Index}

A Index é uma empresa de grande porte que foi fundada em 1914 na cidade Esslingen, na Alemanha.

O grupo apresenta unidades produtivas na Alemanha, nos EUA, na França e no Brasil. As unidades de venda e representação dos produtos Index estão sediados na Alemanha, França, Suécia, EUA, Brasil e China.

Desde 1975, o grupo Index começou a produzir tornos multifusos e tornos com controle numérico computadorizado. Em 1997, a Index incorporou a empresa Traub-Drehmaschinen, da cidade vizinha de Reichenbach/Fils, como uma filial autônoma. Em 2002, a Index Traub começou a produzir tornos multifuncionais capazes de integrar diversas tecnologias e processos em uma única máquina.

No Brasil, o grupo Index iniciou suas atividades com um escritório de vendas em São Paulo e, em 1973, inaugurou sua unidade produtiva na cidade de Sorocaba, no interior de São Paulo. A filial está instalada em um condomínio de empresas juntamente com a filial brasileira da empresa alemã Heller.

Até 1979, a filial brasileira produzia tornos automáticos convencionais. A partir de 1980, a Index Brasil começou a produzir tornos CNC. Com a incorporação da marca Traub em 1997, a filial brasileira iniciou a comercialização tornos de cabeçote móvel.

A empresa produz linhas de tornos CNC, o que abrange tornos CNC horizontais e verticais, centros de torneamento-fresamento, centros de torneamento e retífica e tornos CNC multifusos. As linhas de produtos da marca Traub é formada por tornos universais, torno de cabeçote móvel automático, torno monofuso de barras, TX8i Control Series e sistema de programação e simulação. 
De acordo com o sítio da empresa, a Index Brasil apresenta alternativas para a usinagem completa de peças torneadas, tanto para a fabricação em série como para a produção de peças individuais. Além disso, a empresa dispõe de serviços de assistência técnica; treinamento Index Traub; serviços de instalação e entrega técnica; manutenção das máquinas; reforma, revisão e retrofitting.

A Index também oferece serviço de suporte online com informações técnicas sobre ferramentas e produtos para orientar a compra.

Os principais setores usuários das máquinas-ferramenta da Index Brasil são a indústria automotiva e seus fornecedores; empresas de engenharia elétrica, tecnologia médica e indústrias de ótica e precisão mecânica. Além disso, a empresa já vendeu modelos de máquinas para as indústria eletrônica e eletrotécnica.

As máquinas produzidas pela empresa Index no mundo são desenvolvidas inicialmente no centro tecnológico de Baden-Württemberg. As áreas de engenharia e de pesquisa e desenvolvimento concentram $10 \%$ do total dos colaboradores da empresa e assumem papel importante para o desenvolvimetno de tecnologias da empresa

Desde o início de suas atividades no mercado brasileiro, a empresa tem uma estratégia de produção pautada na nacionalização de alguns modelos de máquinas alemã considerando as caracteristicas da demanda de usuários do Brasil.

De acordo com notícia publicada no sítio da empresa, nos últimos três anos, a Index empresa começou a atualizar seu portfólio de produtos fabricados no Brasil, com o objetivo de transformar a filial brasileira em um centro de competência e pólo de exportação para as demais unidades do grupo.

A área de engenharia da filial brasileira da Index está finalizando o desenvolvimento de uma nova máquina em conjunto com a engenharia da matriz.

O projeto da máquina trabalha com novo conceito tecnologico de custos, a ser adotado nos proximos projetos desenvolvidos pelo grupo. A produção da máquina irá complementar a demanda global que é suprida por produtos provenientes da matriz alemã. Para o mercado brasileiro, o novo projeto atenderá diversos mercados, mas principalmente os mercados energético, automotivo e de construção.

O sítio da empresa não apresenta informações quantitativas sobre o desempenho das vendas, produção, atuaçao no mercado externo/interno, pesquisa e desenvolvimento e investimentos.

Fonte: Sítio da empresa Index matriz e filial do Brasil. Disponível em: <http://www.indexwerke.de/ita/portugiesisch/index PTG HTML.htm> e <www.indextornos.com.br>. Acesso em 10. Jul.2012. 


\section{Indústrias Romi}

A Indústria Romi S.A é uma empresa brasileira de grande porte que foi fundada em 1930. A empresa iniciou suas atividades com a produção de máquinas agrícolas e apenas em 1941, começou a produção do primeiro torno mecânico, de marca IMOR e modelo TP-2.

Até o final da década de 1960, a empresa fabricava modelos de tratores e tornos mecânicos. Além disso, ela desenvolveu um modelo de carro brasileiro denominado RomiIsetta.

Na década de 1970, a empresa apresentou expansão de seus negócios com o início da produção de máquinas injetoras de plástico (1974) e das atividades de fundição (1976). Além disso, a empresa começou a produção de tornos com comandos numéricos (1973), que foi o primeiro torno CNC produzido no Brasil.

A partir de meados da década de 1970, a Romi investiu na expansão da área de produção, com a construção da unidade fabril 11, que produz máquinas especiais e de grande porte (1978); da unidade fabril 15, que fabrica máquinas injetoras de plástico (1979); e da unidade Fabril 14, que produz componente e painéis eletroeletrônicos (1985).

Em 1985 a Romi criou a Romi Machine Tools, Ltd. nos EUA, uma subsidiária Romi S.A. que se tornou responsável pelo suporte à rede de distribuição dos produtos Romi no mercado norte-americano.

Nos anos 90, a empresa deu continuidade à estratégia de ampliação da área produtiva com construção da unidade fabril 16, que produz Centros de Torneamento e Centros de Usinagem.

Desde 2006, a empresa apresenta Sistema de Gestão da Qualidade que abrange todos os produtos Romi. Em 2007, a Romi começou a migrar do mercado tradicional para o Novo Mercado Bovespa.

Nos últimos quinze anos, a empresa Romi investiu em estratégias produtivas e comerciais visando o desenvolvimento de produtos e a maior inserção no mercado interno e externo.

No mercado interno, a Romi comprou a empresa JAC Indústria Metalúrgica Ltda, fabricante de sopradoras de plásticos (2008); e a empresa Digmotor Equipamentos Eletromecânicos Digitais Ltda, que produz máquinas sopradoras para pré-formas PET (2009).

No mercado externo, a Romi criou a subsidiária Romi Itália s.r.l. (2008), com sede na Turim, Itália, para suporte às atividades da empresa na Europa. Outra estratégia importante para o desempenho da Romi foi a compra de ativos da Sandretto Industrie s.r.l., empresa que produz máquinas injetoras de plástico na cidade de Grugliasco e Pont Canavese, na região de Turim (Itália).

Em 2009, a Romi assinou acordo com a empresa italiana Lazzati s.p.a., de Rescaldina (Itália) para a fabricação da madrilhadoras no mercado brasileiro. E em junho de 2010, a Romi 
assinou acordo com a empresa italiana PFG s.p.a. para viabilizar a fabricação de Centros de Usinagem de Coluna Móvel.

Com as aquisições e parcerias realizadas nos últimos anos, a Romi ampliou as competências e conhecimentos em alguns modelos de produtos, o que possibilitou 0 lançamento de vários modelos de máquinas.

Particularmente em 2011, a empresa lançou nove modelos de máquinas durante a FEIMAFE 2011: Centro de Usinagem Vertical de Coluna Móvel ROMI DCM 3000; Centro de Usinagem Vertical ROMI D 1000AP Direct Drive; Nova versão do Centro de Usinagem Horizontal ROMI PH 630; Centros de Torneamento ROMI GL 170G, ROMI GL 350, ROMI GL 350M e o ROMI G 550M. Também foram lançados o Centur 40A e os tornos pesados Centur 60 e 60A e 60B e Tornos Universais da família ROMI T.

Ainda em 2011, a Romi começou a vender as máquinas Série EN, que realizam atividades de torneamento de tubos de aço utilizados na extração e transporte de petróleo.

De acordo com o sítio da Romi, até 31/12/11 a empresa apresentava treze unidades fabris instaladas numa área de mais de $150 \mathrm{mil} \mathrm{m}^{2}$ na cidade de Santa Bárbara, no interior de São Paulo.

Dentre essas treze unidades, cinco são destinadas à montagem final de máquinas industriais, duas são responsáveis por atividades de fundição, quatro unidades cuidam da usinagem de componentes mecânicos, uma unidade produz componentes de chapas de aço e outra unidade é responsável pela montagem de painéis e componentes eletrônicos.

Além disso, a Romi mantém a unidade produtiva localizada na cidade de Grugliasco e Pont Canavese, na região de Turim (Itália).

As operações da Romi estão organizadas em três unidades de negócios: máquinasferramenta; máquinas para plásticos; e peças de ferro fundido.

O segmento de negócios de máquinas-ferramenta abrange as máquinas e equipamentos para trabalhar metal por arranque de cavaco. Os produtos fabricados nesse segmento são os tornos CNC, tornos Convencionais, centros de torneamento, centros de Usinagem e madrilhadora.

O segmento de máquinas para plástico é responsável pela produção de máquinas e equipamentos para moldar plástico por injeção e por sopro. O segmento de peças fundidas, por sua vez, produz peças de ferro fundido cinzento, nodular e vermicular, fornecidas brutas ou usinadas.

Além das atividades produtivas, a Romi oferece os serviços: Romi Assistência Integral (RAI), Diagnóstico Remoto, Apoio Técnico em Processos (ATP), Serviços de Manutenção Customizada e Treinamento em Manutenção.

De acordo com o sítio da empresa, as principais vantagens competitivas da Romi no mercado doméstico são: produtos com tecnologia de ponta, rede própria de distribuição no 
país, assistência técnica permanente, disponibilização de financiamento atrativo e em moeda local aos seus clientes e curto prazo de entrega dos seus produtos.

Os principais clientes dos produtos fabricados pela Romi são: segmento automotivo (leves e pesados), de máquinas agrícolas, de bens de capital, de bens de consumo, de ferramentaria, de equipamentos hidráulicos, entre muitos outros.

No ano de 2010, a Romi vendeu 2.326 unidades de máquinas-ferramenta, 425 unidades de máquinas para plásticos e 11.86 toneladas de peças usinadas. Esses dados apresentam, respectivamente, um acréscimo de $60 \%, 37,5 \%$ e $38,8 \%$ sobre o volume de produtos vendidos no período anterior.

A receita operacional líquida obtida a partir das vendas desses produtos em 2010 foi de $R \$ 673.529$, sendo $R \$ 427.104$ milhões (máquinas-ferramenta), $R \$ 179.413$ milhões (máquinas para plástico) e $\mathrm{R} \$ 67.012$ milhões (usinados). Na comparação com as vendas efetuadas em 2009, houve acréscimo de 37,5\%, 49,5 e 49,2\% das vendas das três unidades de negócios da Romi.

A unidade de negócios máquinas-ferramenta é a maior unidade de negócios da Romi, sendo responsável por $63,4 \%$ da Receita operacional líquida (2010). O desempenho da unidade de negócios para plásticos correspondeu a $26,6 \%$ da receita operacional no mesmo período. Já a unidade de negócios Fundidos e Usinados contribui para 10,0\% da receita operacional líquida da empresa.

No ano de 2011, a Romi vendeu $R \$ 631.954$ milhões, sendo $R \$ 407.107$ milhões obtidos a partir das vendas de máquinas-ferramenta, $R \$ 126.336$ milhões para máquinas para plástico e $\mathrm{R} \$ 97.611$ milhões para usinados e fundidos.

A empresa apresenta importante participação no mercado externo. As exportações da Romi aumentaram de US\$25,2 milhões em 2010 para US $\$ 45,7$ milhões em 2011, o que representa um crescimento de $81,4 \%$.

Neste período, a Europa foi responsável por 56,8\% das exportações (65,9\% em 2010), os EUA representaram $26,9 \%$ (24,2\% em 2010) e o mercado da América Latina foi responsável por $16,3 \%$ (9,4\% em 2010) das vendas da Romi no mercado externo.

Os investimentos realizados pela empresa nos últimos anos apresentaram queda de $\mathrm{R} \$ 51,8$ milhões em 2009 para $\mathrm{R} \$ 33,3$ milhões em 2010 e $\mathrm{R} \$ 19,7$ milhões em 2011.

Ao longo de 2011 a empresa Romi investiu, principalmente, na manutenção, produtividade e modernização do parque industrial, e em tecnologia de informação. Em 2010, os investimentos da empresa foram destinados basicamente para manutenção e ampliação do parque fabril, a ampliação das unidades de montagem e em tecnologia de informação.

Os investimentos em 2009 atingiram o montante de $\mathrm{R} \$ 51,8$ milhões, o que representa uma queda de 58,0\% em relação ao volume de investimentos de 2008 ( $R \$ 123,3$ milhões). Em 2009 , os recursos foram utilizados na conclusão dos projetos de investimentos denominados 
Paradiso (especificamente, na conclusão da ampliação da unidade de máquinas pesadas) e Vulcano (implantação e start up da nova fundição).

No período de 2007 a 2009, as despesas com pesquisa e desenvolvimento realizadas pela Romi totalizaram $R \$ 77,8$ milhões. Particularmente em 2009 , os investimentos em tecnologia, pesquisa e desenvolvimento contabilizaram $R \$ 22,7$ milhões $(4,8 \%$ da receita operacional líquida consolidada). De maneira geral, os investimentos da Romi em P\&D estão direcionados para o desenvolvimento de novos produtos e melhoraria e atualização dos produtos existentes, visando os ganhos de produtividade e a otimização na escolha de materiais e processos industriais. No segmento de máquinas-ferramenta, por exemplo, a Romi investe aproximadamente $4 \%$ do seu faturamento líquido anual em pesquisa e desenvolvimento (P\&D) de seus produtos e processos.

No ambiente interno, a Romi conta com equipe de pesquisa e desenvolvimento composta por 223 profissionais (engenheiros, projetistas e técnicos altamente qualificados). Além disso, as unidades fabris são integradas através de sistemas de CAD/CAM, o que possibilita mais flexibilidade e melhor desempenho na produção das máquinas.

A Fundição da Romi possui setor de engenharia dotado de corpo técnico qualificado, treinado e experiente. A empresa utiliza recursos como CAD e FMEA no projeto do ferramental como no processo de produção. Além disso, a empresa possui setor próprio de modelação que emprega funcionários qualificados experientes e tem competência para o desenvolvimento de protótipos e produção de modelos em madeira, ferro fundido, alumínio, resina e isopor.

Nas últimas duas décadas, a Romi realizou parcerias com empresas estrangeiras e o meio acadêmico nacional como forma de promover o desenvolvimento dos seus produtos e de tecnologias.

A empresa estabeleceu parcerias com algumas empresas líderes globais em seus ramos de atuação, tais como a Lazzati e PFG Macchine Utensili (Itália), com o objetivo de ampliar o acesso a informações tecnológicas. Outro fator importante para o desenvolvimento de tecnologias da Romi foi a parceria realizada com o meio acadêmico e com institutos de tecnologia.

Fonte: Sítio da empresa Romi. Disponível em: www.romi.com.br. Acesso em: 18.mar.2012. 


\section{Informações sobre os grupos de pesquisa visitados}

As informações apresentadas no quadro a seguir foram obtidas a partir de pesquisa realizada no Diretório Grupo de Pesquisa CNPQ (2012)

\begin{tabular}{|c|c|c|c|c|c|c|c|c|}
\hline \multicolumn{2}{|r|}{ Questões } & \multirow{2}{*}{$\begin{array}{c}\text { Processos de } \\
\text { Fabricação } \\
\text { (DEP/FEM/UNICAMP) } \\
1983 \\
\end{array}$} & \multirow{2}{*}{\begin{tabular}{|c} 
Dinâmica, Identificação e \\
Controle de Estruras \\
(DEP/FEM/UNICAMP)
\end{tabular}} & \multirow{2}{*}{$\begin{array}{c}\begin{array}{c}\text { Núcleo para Projeto e } \\
\text { Manufatura Integrados } \\
\text { (DEP/FEAU/UNIMEP) }\end{array} \\
1995 \\
\end{array}$} & \multirow{2}{*}{$\begin{array}{c}\text { Núcleo de } \\
\text { Desenvolvimento e } \\
\text { Otimização de Processos } \\
\text { e Sistemas Produtivos } \\
\text { (DEP/FEAU/UNIMEP) } \\
1996 \\
\end{array}$} & \multirow{2}{*}{\begin{tabular}{|c} 
Grupo de Pesquisa em \\
$\begin{array}{c}\text { Usinagem por Abrasão } \\
\text { (Faculdade de }\end{array}$ \\
$\begin{array}{c}\text { Engenharia e Tecnologia } \\
\text { de Bauru/UNESP) }\end{array}$ \\
1992 \\
\end{tabular}} & \multirow{2}{*}{\begin{tabular}{|c}
$\begin{array}{c}\text { Otimização e Processos } \\
\text { de Manufatura } \\
\text { (DEP/EESC/USP) }\end{array}$ \\
1990 \\
\end{tabular}} & \multirow{2}{*}{$\begin{array}{c}\text { Usinagem com Altas } \\
\text { Velocidades } \\
\text { (DEP/EESC/USP) } \\
1995 \\
\end{array}$} \\
\hline 1 & $\begin{array}{c}\text { Ano de } \\
\text { formação }\end{array}$ & & & & & & & \\
\hline 2 & Órgão & $\begin{array}{l}\text { Faculdade de } \\
\text { Engenharia Mecânica }\end{array}$ & $\begin{array}{l}\text { Faculdade de Engenharia } \\
\text { Mecânica }\end{array}$ & $\begin{array}{l}\text { Faculdade de Engenharia } \\
\text { Arquitetura e Urbanismo }\end{array}$ & $\begin{array}{l}\text { Faculdade de Engenharia } \\
\text { Arquitetura e Urbanismo }\end{array}$ & $\begin{array}{l}\text { Faculdade de Engenharia e } \\
\text { Tecnologia de Bauru }\end{array}$ & $\begin{array}{l}\text { Escola de Engenharia de } \\
\text { São Carlos }\end{array}$ & $\begin{array}{l}\text { Escola de Engenharia de } \\
\text { São Carlos }\end{array}$ \\
\hline 3 & Unidade & \begin{tabular}{|l|} 
Departamento de \\
Engenharia de \\
Fabricação \\
\end{tabular} & $\begin{array}{l}\text { Departamento de Projeto } \\
\text { Mecânico }\end{array}$ & \begin{tabular}{|l|} 
Laboratório de Sistemas \\
Computacionais Para \\
Projeto e Manufatura \\
\end{tabular} & $\begin{array}{l}\text { Programa de Pós- } \\
\text { graduação em Engenharia } \\
\text { de Produção - PPGEP } \\
\end{array}$ & $\begin{array}{l}\text { Departamento de } \\
\text { Engenharia Mecânica }\end{array}$ & $\begin{array}{l}\text { Departamento de } \\
\text { Engenharia de Produção }\end{array}$ & $\begin{array}{l}\text { Departamento de } \\
\text { Engenharia de Produção }\end{array}$ \\
\hline 4 & \begin{tabular}{|c|} 
Área \\
predominant \\
e
\end{tabular} & $\begin{array}{l}\text { Engenharias; } \\
\text { Engenharia Mecânica }\end{array}$ & $\begin{array}{l}\text { Engenharias; Engenharia } \\
\text { Mecânica }\end{array}$ & $\begin{array}{l}\text { Engenharias; Engenharia } \\
\text { Mecânica }\end{array}$ & $\begin{array}{l}\text { Engenharias; Engenharia } \\
\text { de Produção. }\end{array}$ & $\begin{array}{l}\text { Engenharias; Engenharia } \\
\text { Mecânica. }\end{array}$ & $\begin{array}{l}\text { Engenharias; Engenharia } \\
\text { Mecânica. }\end{array}$ & $\begin{array}{l}\text { Engenharias; Engenharia } \\
\text { Mecânica. }\end{array}$ \\
\hline 5 & Homepage & $\begin{array}{l}\text { http://www.fem.unicamp. } \\
\text { br }\end{array}$ & $\begin{array}{l}\text { http://fem.unicamp.br/ kurk } \\
\text { a }\end{array}$ & www.unimep.br/scpm & www.unimep.br/feau/ppgep & www.feb.unesp.br & http://www.opf.sc.usp.br/ & $\begin{array}{l}\text { http:www.opf.sc.usp.br/op } \\
\text { f }\end{array}$ \\
\hline
\end{tabular}




\begin{tabular}{|c|c|c|c|c|c|c|c|c|}
\hline & Questões & $\begin{array}{c}\text { Processos de } \\
\text { Fabricação } \\
\text { (DEP/FEM/UNICAMP) }\end{array}$ & $\begin{array}{l}\text { Dinâmica, Identificacãao e } \\
\text { Controle de Estruturas } \\
\text { (DEP/FEM/UNICAMP) }\end{array}$ & $\begin{array}{l}\text { Núcleo para Projeto e } \\
\text { Manufatura Integrados } \\
\text { (DEP/FEAU/UNIMEP) }\end{array}$ & \begin{tabular}{|c|} 
Núcleo de \\
Desenvolvimento e \\
Otimização de Processos \\
e Sistemas Produtivos \\
(DEP/FEAU/UNIMEP) \\
\end{tabular} & $\begin{array}{c}\text { Grupo de Pesquisa em } \\
\text { Usinagem por Abrasão } \\
\text { (Faculdade de } \\
\text { Engenharia e Tecnologia } \\
\text { de Bauru/UNESP) }\end{array}$ & $\begin{array}{l}\text { Otimização e Processos } \\
\text { de Manufatura } \\
\text { (DEP/EESC/USP) }\end{array}$ & $\begin{array}{l}\text { Usinagem com Altas } \\
\text { Velocidades } \\
\text { (DEP/EESC/USP) }\end{array}$ \\
\hline 6 & $\begin{array}{l}\text { Surgimento } \\
\text { do grupo }\end{array}$ & n.d. & n.d. & $\begin{array}{l}\text { O NPMI nasceu da } \\
\text { experiência de um } \\
\text { relacionamento com } \\
\text { empresas e universidades } \\
\text { visando o desenvolvimento } \\
\text { de pesquisa tecnológica e } \\
\text { sua apropriação pelos } \\
\text { setores produtivos. Dentro } \\
\text { deste enfoque o SCPM foi } \\
\text { o primeiro laboratório a } \\
\text { trazer a Tecnologia de } \\
\text { Usinagem em Altíssima } \\
\text { Velocidade (HSC) para o } \\
\text { Brasil, através do } \\
\text { Seminário Internacional de } \\
\text { Alta Tecnologia, que vem } \\
\text { sendo realizado } \\
\text { regularmente desde } 1996 \text {. }\end{array}$ & n.d. & n.d. & n.d. & n.d. \\
\hline
\end{tabular}




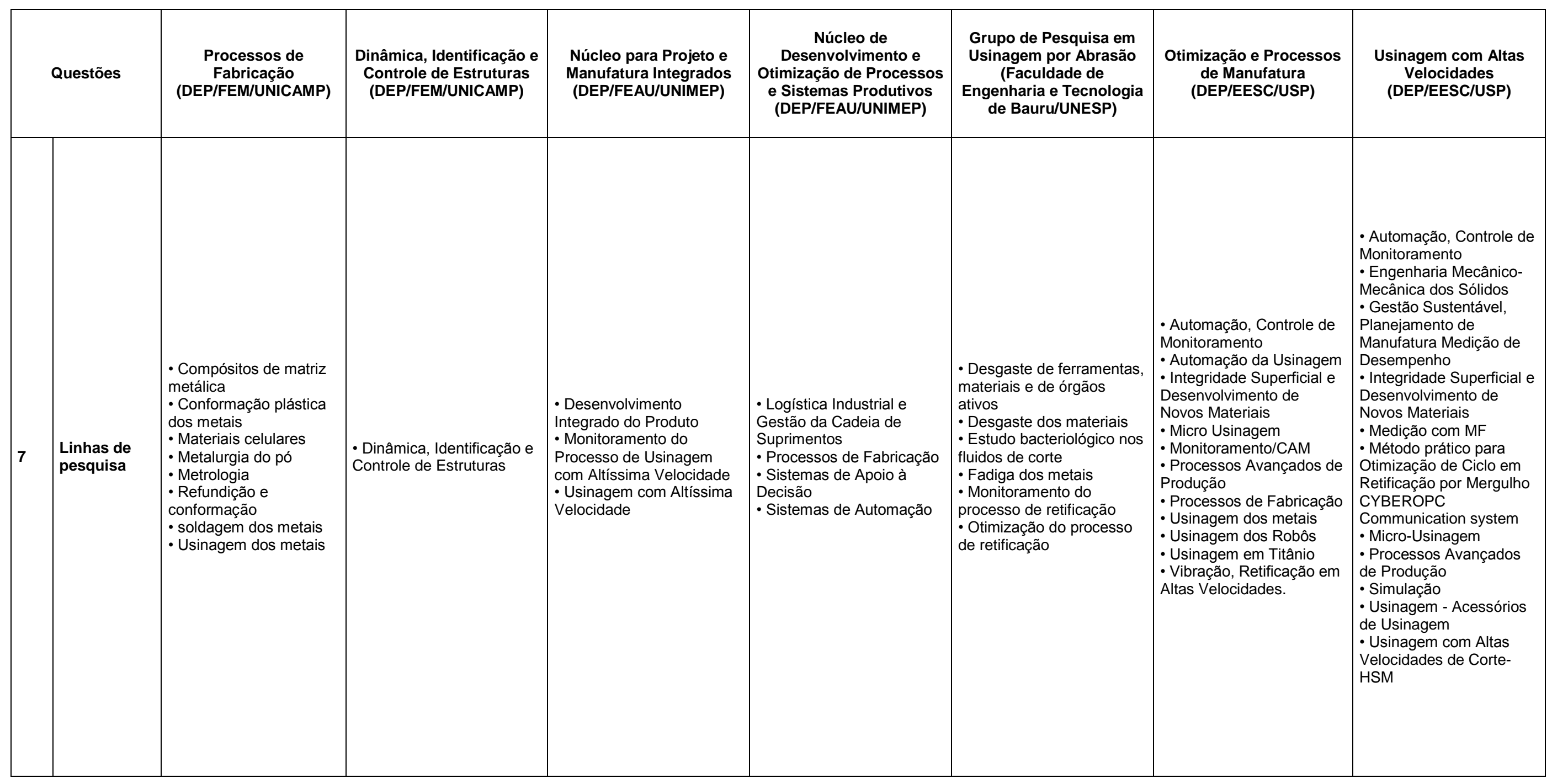




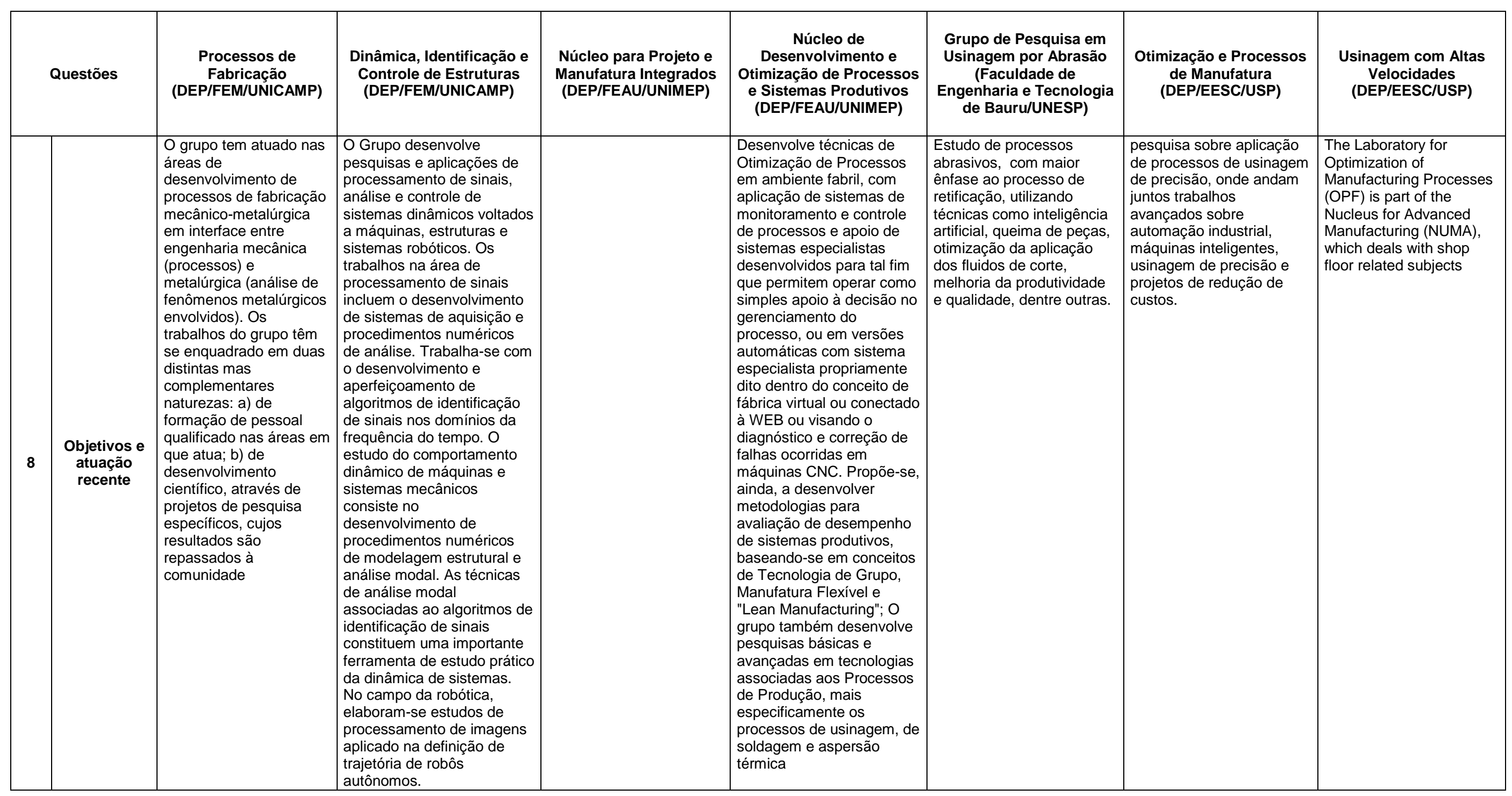




\begin{tabular}{|c|c|c|c|c|c|c|c|c|}
\hline & Questões & $\begin{array}{c}\text { Processos de } \\
\text { Fabricação } \\
\text { (DEP/FEM/UNICAMP) }\end{array}$ & $\begin{array}{c}\text { Dinâmica, Identificação e } \\
\text { Controle de Estruturass } \\
\text { (DEP/FEM/UNICAMP) }\end{array}$ & $\begin{array}{l}\text { Núcleo para Projeto e } \\
\text { Manufatura Integrados } \\
\text { (DEP/FEAU/UNIMEP) }\end{array}$ & \begin{tabular}{|c|} 
Núcleo de \\
Desenvolvimento e \\
Otimização de Processos \\
e Sistemas Produtivos \\
(DEP/FEAU/UNIMEP)
\end{tabular} & $\begin{array}{c}\text { Grupo de Pesquisa em } \\
\text { Usinagem por Abrasão } \\
\text { (Faculdade de } \\
\text { Engenharia e Tecnologia } \\
\text { de Bauru/UNESP) }\end{array}$ & $\begin{array}{c}\text { Otimização e Processos } \\
\text { de Manufatura } \\
\text { (DEP/EESC/USP) }\end{array}$ & $\begin{array}{l}\text { Usinagem com Altas } \\
\text { Velocidades } \\
\text { (DEP/EESC/USP) }\end{array}$ \\
\hline 9 & $\begin{array}{l}\text { Interação } \\
\text { declarada } \\
\text { com o setor } \\
\text { produtivo } \\
\text { (CNPq) }\end{array}$ & n.d. & n.d. & $\begin{array}{l}\text { - Siemens PLM Software } \\
\text { do Brasil - SIEMENS PLM } \\
\text { - Siemens - Lapa - } \\
\text { SIEMENS } \\
\text { - Sandvik do Brasil - } \\
\text { SANDVIK } \\
\text { - Indústrias Romi - ROMI } \\
\text { S/A }\end{array}$ & $\begin{array}{l}\text { - LabMat Análises e } \\
\text { Ensaios Materiais - LabMat }\end{array}$ & $\begin{array}{l}\text { - Nikkon Ferramentas de } \\
\text { Corte - NIKKON } \\
\text { - Agena Resinas e Colas - } \\
\text { AGENA } \\
\text { - Royall Diamond } \\
\text { Ferramentas Diamantadas } \\
\text { - ROYALL DIAMOND }\end{array}$ & $\begin{array}{l}\text { - Microma Projetos e } \\
\text { Construcões Mecanicas - } \\
\text { MICROMA } \\
\text { - Index Tornos } \\
\text { Automaticos Indústria e } \\
\text { Comércio - INDEX } \\
\text { - Aços Villares - Matriz - } \\
\text { AÇOS VILLARES } \\
\text { - Saint-Gobain Abrasivos - } \\
\text { SAINT-GOBAIN } \\
\text { - Indústria de Máquinas } \\
\text { Zema - ZEMA }\end{array}$ & $\begin{array}{l}\text { - Index Tornos } \\
\text { Automaticos Indústria e } \\
\text { Comércio - INDEX } \\
\text { - Indústrias Romi - ROMI } \\
\text { S/A } \\
\text { - Tecno How Engenharia } \\
\text { Industrial e Comércio - } \\
\text { TECNO HOW } \\
\text { - Saint-Gobain Abrasivos } \\
\text { - SAINT-GOBAIN }\end{array}$ \\
\hline
\end{tabular}




\begin{tabular}{|c|c|c|c|c|c|c|c|c|}
\hline \multicolumn{2}{|r|}{ Questões } & $\begin{array}{c}\text { Processos de } \\
\text { Fabricação } \\
\text { (DEP/FEM/UNICAMP } \\
\text { ) }\end{array}$ & $\begin{array}{l}\text { Dinâmica, Identificação } \\
\text { e Controle de } \\
\text { Estruturas } \\
\text { (DEP/FEM/UNICAMP) }\end{array}$ & $\begin{array}{c}\text { Núcleo para Projeto e } \\
\text { Manufatura } \\
\text { Integrados } \\
\text { (DEP/FEAU/UNIMEP) }\end{array}$ & \begin{tabular}{|c|} 
Núcleo de \\
Desenvolvimento e \\
Otimização de \\
Processos e Sistemas \\
Produtivos \\
(DEP/FEAU/UNIMEP)
\end{tabular} & \begin{tabular}{|c|} 
Grupo de Pesquisa em \\
Usinagem por \\
Abrasão (Faculdade \\
de Engenharia e \\
Tecnologia de \\
Bauru/UNESP)
\end{tabular} & $\begin{array}{c}\text { Otimização e } \\
\text { Processos de } \\
\text { Manufatura } \\
\text { (DEP/EESC/USP) }\end{array}$ & $\begin{array}{c}\text { Usinagem com Altas } \\
\text { Velocidades } \\
\text { (DEP/EESC/USP) }\end{array}$ \\
\hline 10 & $\begin{array}{l}\text { Interação } \\
\text { com outros } \\
\text { grupos e } \\
\text { projetos }\end{array}$ & n.d. & n.d. & \begin{tabular}{|l|} 
O Núcleo possui parceria \\
com a University of \\
Tecnology Darmstadt, \\
Alemanha, através da \\
qual tem ocorrido um \\
intenso intercâmbio \\
científico de estudantes e \\
de professores, inclusive \\
gerando uma dissertação \\
de mestrado agraciada \\
com o Prêmio Schenck na \\
Alemanha. É a única \\
entidade na América \\
Latina filiada a ProSTEP \\
e.V., Alemanha, - \\
associação para o \\
desenvolvimento de \\
processadores para as \\
Normas ISO 10303 \\
(STEP) com a qual está \\
realizando um projeto de \\
transferência de \\
tecnologia visando \\
oferecer os mesmos \\
serviços na área de \\
Tecnologia de Dados do \\
Produto, além de sediar a \\
Secretaria Técnica da ISO \\
para o AP 214
\end{tabular} & & \begin{tabular}{|l|} 
No período de 1999 a 2002 \\
o Grupo de Pesquisa em \\
Usinagem por Abrasão \\
integrou-se formalmente a \\
Rede Metal Mecânica, \\
Sub-rede Usinagem, do \\
Programa de Redes \\
Cooperativas de Pesquisa - \\
RECOPE, apoiado pela \\
FINEP. \\
De 2001 a 2007 o mesmo \\
grupo integrou-se ao \\
Instituto Fábrica do Milênio \\
- IFM (versões 1 e 2), \\
apoiado pelo CNPq. A \\
interação com cientistas de \\
renome internacional, \\
universidade, institutos de \\
pesquisa de excelência e \\
empresas, agrega ainda \\
mais confiabilidade e \\
agilidade nas pesquisas \\
desenvolvidas direcionado \\
os traballhos de P\&D a \\
assuntos de impacto \\
econômico e social.
\end{tabular} & n.d. & n.d. \\
\hline
\end{tabular}

Fonte: Elaboração própria, com base nas informações disponíveis no Diretório Grupo de Pesquisas CNPq (2012). 